\author{
UNIVERSIDADE DE SÃO PAULO \\ FACULDADE DE FILOSOFIA, LETRAS E CIÊNCIAS HUMANAS \\ DEPARTAMENTO DE GEOGRAFIA \\ PROGRAMA DE PÓS-GRADUAÇÃO EM GEOGRAFIA HUMANA
}

\title{
DIVINA TRADIÇÃO ILUMINA MOGI DAS CRUZES O ESPÍRITO SANTO FAZ A FESTA
}

Neusa de Fátima Mariano

Tese apresentada ao Programa de Pós-Graduação em Geografia Humana, do Departamento de Geografia da Faculdade de Filosofia, Letras e Ciências Humanas da Universidade de São Paulo para obtenção do título de Doutor em Geografia Humana.

Orientadora: Profa. Dra ${ }^{a}$ Margarida Maria de Andrade

São Paulo

2007 
Serviço de Biblioteca e Documentação da Faculdade de Filosofia, Letras e Ciências Humanas da Universidade de São Paulo

Mariano, Neusa de Fátima.

Divina tradição ilumina Mogi das Cruzes. O Espírito Santo faz a festa / Neusa de Fátima Mariano ; orientadora Margarida Maria de Andrade. -- São Paulo, 2007.

209f. : il.

Tese (Doutorado - Programa de Pós-Graduação em Geografia Humana. Área de concentração: Geografia Humana) - Departamento de Geografia da Faculdade de Filosofia, Letras e Ciências Humanas da Universidade de São Paulo.

1. Festas folclóricas - Brasil; Mogi das Cruzes (SP). 2. Festas religiosas - Mogi das Cruzes (SP); Brasil. 3. Cultura popular - Mogi das Cruzes (SP); Brasil. 4. Festa do Divino Espírito Santo (Mogi das Cruzes; São Paulo; Brasil). I. Título. 


\section{Tonsideraçōes de T̃tninha}

\section{Tora Goralina}

Mestior do que a criatura,

Fez o criador a criação.

$\mathscr{\mathscr { T }}$ criatura é fimitada.

Otempo, o espaço,

Dormas e costumes.

Erros e acertos.

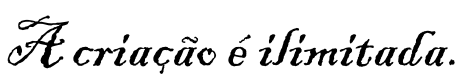

Excede o tempo e o meio.

Projeta-se no Gosmos.

\section{pdfMachine}

A pdf writer that produces quality PDF files with ease!

Produce quality PDF files in seconds and preserve the integrity of your original documents. Compatible across nearly all Windows platforms, simply open the document you want to convert, click "print", select the 


\section{AGRADECIMENTOS}

Passaram-se mais de quatro anos, e agora, a tese está pronta. A pesquisa sempre continua, ainda mais quando ela permite o florescimento de novas questões.

Gostaria de agradecer revelando o nome de cada um que, de uma forma ou de outra, contribuiu para a realização do meu trabalho. Entretanto, como tive a felicidade de contar com o apoio de tantos amigos, temo ser injusta e, por distração, esquecer de citar alguém.

Somente lembrarei aqui, alguns momentos que trouxeram reflexões importantes para a pesquisa: a participação em grupos de estudos, as conversas acadêmicas, as viagens, passeios e conversas com amigos, as aulas que ministrei e o convívio com os alunos, a participação no grupo de violeiros, o contato com os entrevistados na pesquisa, a Festa do Divino de Mogi das Cruzes...

É com grande alegria que agradeço aqui, aos meus familiares, pelo respeito e apoio constantes às minhas escolhas. Com a mesma alegria e admiração, deixo registrado meu agradecimento à Professora Margarida, com quem aprendi muito nestes anos. 


\section{SUMÁRIO}

LISTA DE MAPAS 3

LISTA DE FOTOS

LISTA DE SIGLAS $\quad 7$

RESUMO

$\begin{array}{lr}\text { ABSTRACT } & 9\end{array}$

APRESENTACÃO

\begin{tabular}{lr} 
INTRODUCCÃO & 12 \\
\hline
\end{tabular}

SOBRE GEOGRAFIA, CULTURA, E FESTA

O MOVIMENTO DA PESQUISA - O MÉTODO E A METODOLOGIA

1. A FESTA E O ESPETÁCULO

2. AS ORIGENS DAS HOMENAGENS AO ESPÍRITO SANTO

3. HERANCAS DE PORTUGAL NAS FESTAS RELIGIOSAS POPULARES

3.1 FESTAS DO DiVINO NO BRASIL

4. DOS PRIMÓRDIOS DA FESTA DO DIVINO DE MOGI DAS CRUZES À SUA

ESPETACULARIZAČ̃̃O $\quad 57$

5. A ATUAL FESTA DO DIVINO ESPÍRITO SANTO DE MOGI DAS CRUZES

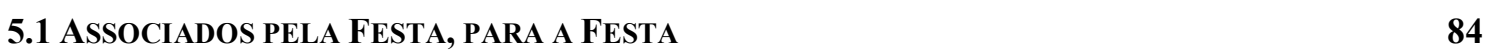

5.2 COMEÇA A FESTA ANTES de A FESTA COMEÇAR

5.2.1 FESTEIROS E CAPITÃES DE MASTRO

5.2.2 REZADEIRAS $\quad 92$

5.3 INICIAM-SE AS FESTIVIDADES DO DIVINO 94

5.3.1 DO RELIGIOSO E DO FOLCLÓRICO 100

5.3.2 NOVENA 101

5.3.3 A Folia do Divino na Passeata das Bandeiras e na Alvorada 104

5.3.4 OS PALMITOS CHEGAM À CIDADE

5.3.5 O DIVINO PASSEIA COM SEUS DEVOTOS 136

5.4 A TERCEIRA PARTE DA FESTA: A QUERMESSE

5.5 Festas do divino em todos os Cantos de Mogi das Cruzes 158

CONSIDERAC̃ÕES FINAIS $\quad 173$

REFERÊNCIAS $\quad 183$

BIBLIOGRAFIA $\quad 183$

$\begin{array}{ll}\text { IMAGENS } & 191\end{array}$

pdfMachine

A pdf writer that produces quality PDF files with ease!

Produce quality PDF files in seconds and preserve the integrity of your original documents. Compatible across

nearly all Windows platforms, simply open the document you want to convert, click "print", select the

"Broadgun pdfMachine printer" and that's it! Get yours now! 
ICONOGRAFIA 191

CARTOGRAFia

REGISTRO SONORO

WEBSITE

JORNAIS

FONTES PRIMÁRIAS

ENTREVISTADOS

\begin{tabular}{lr} 
ANEXOA & 195 \\
\hline
\end{tabular}

SOLICITAÇÃO DE PRENDAS DISTRIBUÍDA AOS ESTUDANTES, NAS ESCOLAS 195

ANEXO B

COROA DO DIVINO ESPÍRITO SANTO

ANEXO C 199

MÚSICAS

\begin{tabular}{ll} 
ANEXO D & 201 \\
\hline
\end{tabular}

ProgramaÇão da Festa do divino espírito Santo 201

\begin{tabular}{lr} 
ANEXO E & 203 \\
\hline
\end{tabular}

Texto sobre a Festa do Divino distribuído na Entrada dos Palmitos 203

\begin{tabular}{lr} 
ANEXO F & 205 \\
\hline
\end{tabular}

Músicas dos Grupos de CONGAda e MoÇAMbiQue $\quad 205$ 


\section{LiSTA DE MAPAS}

Mapa 1 - Mogi das Cruzes na Região Metropolitana de São Paulo

Mapa 2 - Mogi das Cruzes - SP - Divisão por Distritos

Mapa 3 - Centro da Cidade de Mogi das Cruzes em 1901

Mapa 4 - Locais de Quermesses (Festas do Divino de Mogi das Cruzes - 1961 a atual)

Mapa 5 - Locais de Visita da Passeata das Bandeiras

(Festas do Divino de Mogi das Cruzes 2003-2006)

Mapa 6 - Trajeto das Alvoradas (Festas do Divino de Mogi das Cruzes 2003-2006)

Mapa 7 - Trajeto da Entrada dos Palmitos

(Festas do Divino de Mogi das Cruzes 2003-2006)

Mapa 8 - Trajeto da Procissão de Pentecostes

(Festas do Divino de Mogi das Cruzes 2003-2006)

Croqui 1 - Quermesse da Festa do Divino e Mogi das Cruzes - CIP (2005) 


\section{LiSTA DE Fotos}

Fotos 1 e 2: Bandeira do Divino. Óleo sobre tela. Século XIX 53

Foto 3: Festa do Divino de Santa Isabel (1933) 79

Fotos 4 e 5: Festa do Divino de Santa Isabel (1933) 80

Foto 6: Procissão - 1979

$\begin{array}{ll}\text { Foto 7: Nhá Zefa }-1980 & 81\end{array}$

Fotos 8 e 9: Entrada dos Palmitos - 1980

Foto 10: Anjos na Procissão de Pentecostes - 1980

Foto 11: Anjos na Procissão de Pentecostes - 2006

Foto 12: Abertura do Império do Divino 97

$\begin{array}{ll}\text { Foto 13: Império do Divino } & 97\end{array}$

Fotos 14-16: Altar do Divino (2003-2005) 98

Foto 17: Altar do Divino (2006) 99

Foto 18: Cetro e coroa no Império do Divino 99

$\begin{array}{ll}\text { Fotos } 19 \text { e 20: Missa da Novena } & 103\end{array}$

Foto 21: Subimpério na Capela de Nossa Senhora dos Remédios 110

$\begin{array}{ll}\text { Foto 22: Passeata das Bandeiras } & 110\end{array}$

$\begin{array}{ll}\text { Foto 23: Folia do Divino } & 111\end{array}$

Foto 24: Passeata das Bandeiras no jornal O Diário de Mogi 111

$\begin{array}{ll}\text { Foto 25: Missa da Alvorada no Cemitério } & 115\end{array}$

Foto 26: Retorno da Alvorada ao Império do Divino 115

$\begin{array}{ll}\text { Foto 27: Fila do café da Alvorada } & 116\end{array}$

$\begin{array}{ll}\text { Foto 28: Ritual da fogueira, durante Alvorada } & 116\end{array}$ 
Entrada dos Palmitos

$\begin{array}{ll}\text { Fotos } 29 \text { e 30: Grupos de Congada } & 127\end{array}$

Foto 31: Grupo de Moçambique 128

$\begin{array}{ll}\text { Foto 32: Grupo de Trança Fitas } & 128\end{array}$

Foto 33: Festeiros, Capitães de Mastro e autoridades municipais 129

$\begin{array}{ll}\text { Foto 34: Charola } & 129\end{array}$

$\begin{array}{ll}\text { Foto 35: Mudas de palmito no carro de bois } & 130\end{array}$

Foto 36: Crianças no carro de bois 130

$\begin{array}{ll}\text { Foto 37: Carros de bois } & 131\end{array}$

$\begin{array}{ll}\text { Foto 38: Cavaleiros } & 131\end{array}$

Foto 39: Cortejo da Entrada dos Palmitos 132

Foto 40: Grupo de Cavalhada de Guararema 132

Foto 41: Chegada do cortejo ao Império do Divino 133

Foto 42: Fila do “Afogadão" 133

Foto 43: Levantamento do Mastro 135

Foto 44: Grupos “folclóricos” dançam em frente ao Mastro 135

Procissão de Pentecostes

$\begin{array}{ll}\text { Foto 45: Irmãs Carmelitas } & 138\end{array}$

Foto 46: Dons do Divino Espírito Santo 138

Foto 47: Rezadeiras 139

Foto 48: Imperador e Imperatriz do Divino 139

$\begin{array}{ll}\text { Fotos 49 e 50: Grupos de Congada } & 140\end{array}$

Fotos 51 e 52: Andor do Divino - 2005

Fotos 53 e 54: Andor do Divino - $2006 \quad 142$

Fotos 55 e 56: Tapete Ornamental 144

$\begin{array}{ll}\text { Foto 57: Procissão de Pentecostes } & 146\end{array}$

Foto 58: Garis 146 
Foto 59: Subimpério do Divino na Quermesse

Foto 60: Quermesse

\section{Biritiba Ussu}

Foto 61: Império do Divino

160

Foto 62: Tratores na Entrada dos Palmitos

160

Foto 63: Devotos no cortejo

161

Foto 64: Congada de São Benedito

161

\section{Cezar de Souza}

Foto 65: Império do Divino

163

Foto 66: Imperador e Imperatriz do Divino na Procissão de Pentecostes

$\underline{\text { Sabaúna }}$

Foto 67: Procissão de Pentecostes

166

Foto 68: Andor do Divino Espírito Santo 166

$\begin{array}{ll}\text { Foto 69: Cavaleiros na Procissão de Pentecostes } & 167\end{array}$

$\begin{array}{ll}\text { Foto 70: Congada de Santa Efigênia } & 167\end{array}$

$\begin{array}{ll}\text { Foto 71: Preparação do Afogado } & 168\end{array}$

$\begin{array}{ll}\text { Foto 72: Tapete Ornamental } & 168\end{array}$

Fotos 73 e 74: Igreja de Santo Alberto, no Bairro de Itapeti 169

\section{Outras imagens}

Logotipos das Festas do Divino de Mogi das Cruzes (2003-2006) 91

$\begin{array}{ll}\text { Coroa do Divino (Anexo B) } & 196\end{array}$ 


\section{LISTA DE SigLAS}

ACMS

AMDEM

APAE

CIP

CNBB

IBGE

IPHAN

OMEC

UBC

$\mathrm{UMC}$

UNAI

USP

ZUPI
Arquivo da Cúria Metropolitana de São Paulo

Associação Mogicruzense para Defesa do Menor

Associação de Pais e Amigos dos Excepcionais

Centro de Iniciação Profissional

Conferência Nacional dos Bispos do Brasil

Instituto Brasileiro de Geografia e Estatística

Instituto do Patrimônio Histórico e Artístico Nacional

Organização Mogiana de Educação e Cultura

Universidade Braz Cubas

Universidade de Mogi das Cruzes

Universidade Aberta à Integração

Universidade de São Paulo

Zona de Uso Predominantemente Industrial 


\section{RESUMO}

MARIANO, Neusa de Fátima. Divina tradição ilumina Mogi das Cruzes. O Espírito Santo faz a festa. 2007. 205 fl. Tese (Doutorado) - Faculdade de Filosofia, Letras e Ciências Humanas, Departamento de Geografia, Universidade de São Paulo, São Paulo, 2007.

Herança portuguesa, as festividades em homenagem ao Espírito Santo encontraram terreno fértil no Brasil, onde ganharam contornos populares. Em Mogi das Cruzes, município pertencente à Região Metropolitana de São Paulo, a Festa do Divino Espírito Santo é realizada, segundo os documentos consultados, há quase duzentos anos. Em vários momentos, a tradição quase sucumbiu na luta pela sua manutenção diante do processo urbano-industrial, que fragmenta a vida e enfraquece as relações próximas. No início da década de 1990, alguns moradores de Mogi, interessados na manutenção da Festa do Divino do Espírito Santo se reuniram com o objetivo de fundar uma associação que auxiliasse na sua realização, a fim de não deixar a tradição desaparecer. Para isso, a Associação Pró-Festa do Divino, como foi denominada, passou a buscar recursos financeiros junto a empresas (de grande e de pequeno porte) em troca de divulgação de seus logotipos na Festa, colocados em cartazes, panfletos, livros de cânticos, uniformes, etc. Divulgada pelos meios de comunicação, a Festa do Divino de Mogi das Cruzes ganhou impulso, agregando cada vez mais, novos participantes. Nesta "euforia" de crescimento e de arrecadação de recursos, a Festa do Divino foi se configurando também como mercadoria, embora a Associação se identifique e aja como órgão responsável pelo não "desvirtuamento" da tradição. Apesar da crescente espetacularização, acompanhada, inevitavelmente, de uma crescente racionalização na preparação e na realização da Festa, acredita-se haver momentos e elementos que escapam à espetacularização e à racionalização, revelando-a como manifestação da cultura popular. Esta é a questão maior que a pesquisa se propôs a elucidar. Para tanto, buscou no passado da Festa (na Europa, no Brasil, sobretudo em Mogi das Cruzes), elementos que a definiram como manifestação da religiosidade popular e que estariam presentes ainda hoje, como resíduos de tempos e relações pretéritas.

Palavras-chave: festa, Divino Espírito Santo, Mogi das Cruzes, espetáculo, cultura popular. 


\begin{abstract}
MARIANO, Neusa de Fátima. Divine tradition iluminates Mogi das Cruzes. Holy Ghost makes the party. 2007. $208 \mathrm{fl}$. Thesis (Doctorate) - Faculdade de Filosofia, Letras e Ciências Humanas, Departamento de Geografia, Universidade de São Paulo, São Paulo, 2007.
\end{abstract}

Portuguese heritage, the parties in honor to the Holy Ghost met fertile land in Brazil, where they acquired a popular profile. In Mogi das Cruzes, city of Metropolitan Region of São Paulo, the Holy Ghost Party has been performed, according to researched documents, for almost two hundred years. For several times, the tradition was almost finished due to the industrial-urban process, which fragments the life and weaken the nearby relations. In the beginning of 90's, some Mogi residents, interested in the conservation of Holy Ghost gathered themselves in order to found an association to help its achievement and avoid the extinction of the tradition. For that, the Pro-Holy Ghost Party Association, as it has been called, started looking for a sponsorship company (the big or the small ones), by exchanging the company's name divulgation during the Party through logotypes in posters, folders, book's music, uniforms etc. Divulgated by the communication means, the Holy Ghost Party of Mogi das Cruzes received impulse, adding increasingly, new attendees. In the "enthusiasm" of the growth and the finance resource collection, the Holy Ghost Party became a merchandise, however the Association identifies itself and acts as an institution responsible for the "no disparage" of the tradition. In spit of the growing of the spectacle process, necessarily accompanied of growing rationalization in the Party preparing and achievement, we believe there are moments and elements that escape from the spectacling and from the rationalization, showing it as expression of the popular culture. This is the most important question that the research proposed to clarify. For that, pursued in the past of the Party (in Europe, in Brazil, especially in Mogi das Cruzes), elements that defined it as manifest of the popular religiosity and that would be present up to nowadays as residues of time and preterit relations.

Key-words: party, Divine Holy Ghost, Mogi das Cruzes, spectacle, popular culture. 


\section{APRESENTAÇÃo}

A idéia primeira sobre um tema de pesquisa de doutorado vinha de algumas interrogações a partir do trabalho realizado na dissertação de mestrado. Neste estudei as manifestações da cultura caipira diante do processo de modernização no município de Jaú (SP). Desde então iniciei uma busca sobre manifestações caipiras na metrópole de São Paulo. Diferentemente do mestrado, no qual apresentei um pouco do universo caipira por meio da culinária, do imaginário (lendas e crenças), da medicina, da indústria doméstica, das festas, músicas e danças, etc..., a pesquisa de doutorado deveria ser mais pontual, restringindo-se às manifestações da religiosidade popular.

$\mathrm{O}$ passo inicial seria mapear tais festas para um primeiro contato. $\mathrm{O}$ fato de integrar, no ano de 2002, a Orquestra Paulistana de Viola Caipira, sob a regência de Rui Torneze, e cursar viola caipira no Centro de Estudos Musicais Tom Jobim, propiciou o meu encontro com algumas destas festas.

Na ocasião de meu ingresso no programa de pós-graduação, o projeto de pesquisa contemplava uma abordagem de tais festas, realizadas em municípios pertencentes à Região Metropolitana de São Paulo, partindo da hipótese de que tais manifestações poderiam significar permanências da cultura caipira (teria que se buscar o como e o porquê dessas permanências) em uma realidade cada vez mais dominada pelos signos da modernidade e submetida à lógica da economia de mercado.

O primeiro contato com tais manifestações da religiosidade popular aconteceu na Aldeia de Carapicuíba, durante a Festa de Santa Cruzinha, realizada em setembro de 2003. No ano seguinte, conheci a Festa de Santa Cruz, também na Aldeia, que aconteceu no mês de maio, ocasião em que já me propunha a observar, entender e registrar a dança de Santa Cruz, praticada desde o período colonial.

Embu foi outra cidade que chamou minha atenção, também por ocasião da Festa de

\section{pdfMachine}

A pdf writer that produces quality PDF files with ease!

Produce quality PDF files in seconds and preserve the integrity of your original documents. Compatible across nearly all Windows platforms, simply open the document you want to convert, click "print", select the

"Broadgun pdfMachine printer" and that's it! Get yours now! 
Santa Cruz, na qual artistas, desde os mais anônimos aos mais conhecidos, se apresentavam no palco, além de grupos de congada como o de São Benedito, de Cotia. Cabe mencionar que as barracas de doces, salgados e bebidas fazem parte de todas estas festas por mim acompanhadas.

Conheci Sabaúna (distrito de Mogi das Cruzes) em abril de 2003, por ocasião de uma dança oferecida a São Gonçalo, protetor dos violeiros. Naquele momento estava me integrando ao grupo de pesquisa sobre São Gonçalo, formado por alguns membros da Orquestra Paulistana de Viola Caipira (Alberto, Arthur e Sr. Raimundo). No mês seguinte, por ocasião da Festa do Divino, voltaria a Mogi das Cruzes. Ao presenciar o momento de abertura da Festa, a concentração das bandeiras na casa do então Festeiro, e depois a bênção das mesmas na Praça da Catedral, decidi pelo estudo da Festa do Divino de Mogi das Cruzes. Pelas suas proporções, pela mistura de um certo luxo com a simplicidade advinda da forte presença popular, que a diferenciava de outras festas que tinha observado, concluí que seu estudo suscitaria muitas questões e poderia ajudar a compreender o sentido de manifestações da religiosidade popular na realidade atual.

Em 2004, durante a Festa do Divino, descobri que nos distritos de Mogi das Cruzes também eram realizadas homenagens festivas ao Espírito Santo, algumas das quais pude conhecer no ano seguinte. Porém, se abordasse todas as Festas do Divino de Mogi das Cruzes, a pesquisa ficaria ampla demais, e poderia mesmo se inviabilizar. Como sugestão feita pela Banca Examinadora do Exame de Qualificação, restringi a pesquisa à Festa do Divino de Mogi das Cruzes, sem desconsiderar, entretanto a existência de outras Festas menores, realizadas no município.

Durante os quatro anos de desenvolvimento da pesquisa, muitas leituras foram realizadas tendo em vista a formulação mais clara da própria pesquisa e do quadro teórico que deveria orientá-la. Ao mesmo tempo, acompanhei a Festa, de 2003 a $2006^{1}$ e realizei inúmeras entrevistas e consultas a arquivos pessoais e públicos.

Com o presente trabalho, espero ter podido contribuir para os estudos da cultura no âmbito da ciência geográfica e, quem sabe, também para os estudos da relação rural-urbano.

${ }^{1}$ Durante as Festas do Divino de Mogi das Cruzes, realizadas desde 2003 até 2006, contei com a companhia de Herbert Rodrigues, que também pesquisava a Festa, tema de sua dissertação de mestrado em Antronolocia Social 


\section{INTRODUÇÃO}

Mogi das Cruzes, município hoje pertencente à Região Metropolitana de São Paulo $^{2}$, (Mapa 1) nasceu em princípios do século XVII, como núcleo de povoamento formado a partir de projetos de exploração aurífera, promovidos pelos portugueses colonizadores.

Em 1611, o núcleo de povoamento tornou-se vila. Em agosto de 1671, foi criado o município e, em 1855, a antiga vila foi alçada à categoria de cidade. (Plano Diretor do Município de Mogi das Cruzes, 1999/2005). O povoamento de Mogi das Cruzes teve trajetória similar ao da Vila de São Paulo de Piratininga, com a distribuição de terras, a instalação de aldeamentos indígenas, o papel do bandeirismo e finalmente, a economia de excedentes.

Segundo pesquisas de Grinberg (1961), na primeira metade do século XIX, Mogi das Cruzes possuía como base econômica, a agricultura para consumo interno, produzindo farinha de mandioca, feijão, arroz, azeite de amendoim, fumo, algodão, suínos, eqüinos, gado vacum e de lã, além da aguardente de cana.

Somente após o desenvolvimento urbano-industrial de São Paulo, Mogi das Cruzes começou a viver os primeiros momentos de um processo de transformação do espaço de eminentemente rural em urbano. Já no início do século XX, a Prefeitura de Mogi das Cruzes cedeu terrenos e isenção de impostos a empresários que quisessem instalar indústrias no município (GRINBERG, 1961).

${ }^{2}$ Segundo o Instituto Brasileiro de Geografia e Estatística - IBGE, a população de Mogi das Cruzes está contabilizada em 372.419 habitantes em uma área de $714 \mathrm{Km}^{2}$ (www.ibge.gov.br - acesso em abril de 2007). O município está dividido em distritos: Jundiapeba, Braz Cubas, Engenheiro Cezar de Souza Sahaúna Biritiba Iscu Taiacuneha e Ouatinoa além do distrito da sede (Mana 2) pdfMachine A pdf writer that produces quality PDF files with ease!

Produce quality PDF files in seconds and preserve the integrity of your original documents. Compatible across nearly all Windows platforms, simply open the document you want to convert, click "print", select the "Broadgun pdfMachine printer" and that's it! Get yours now! 


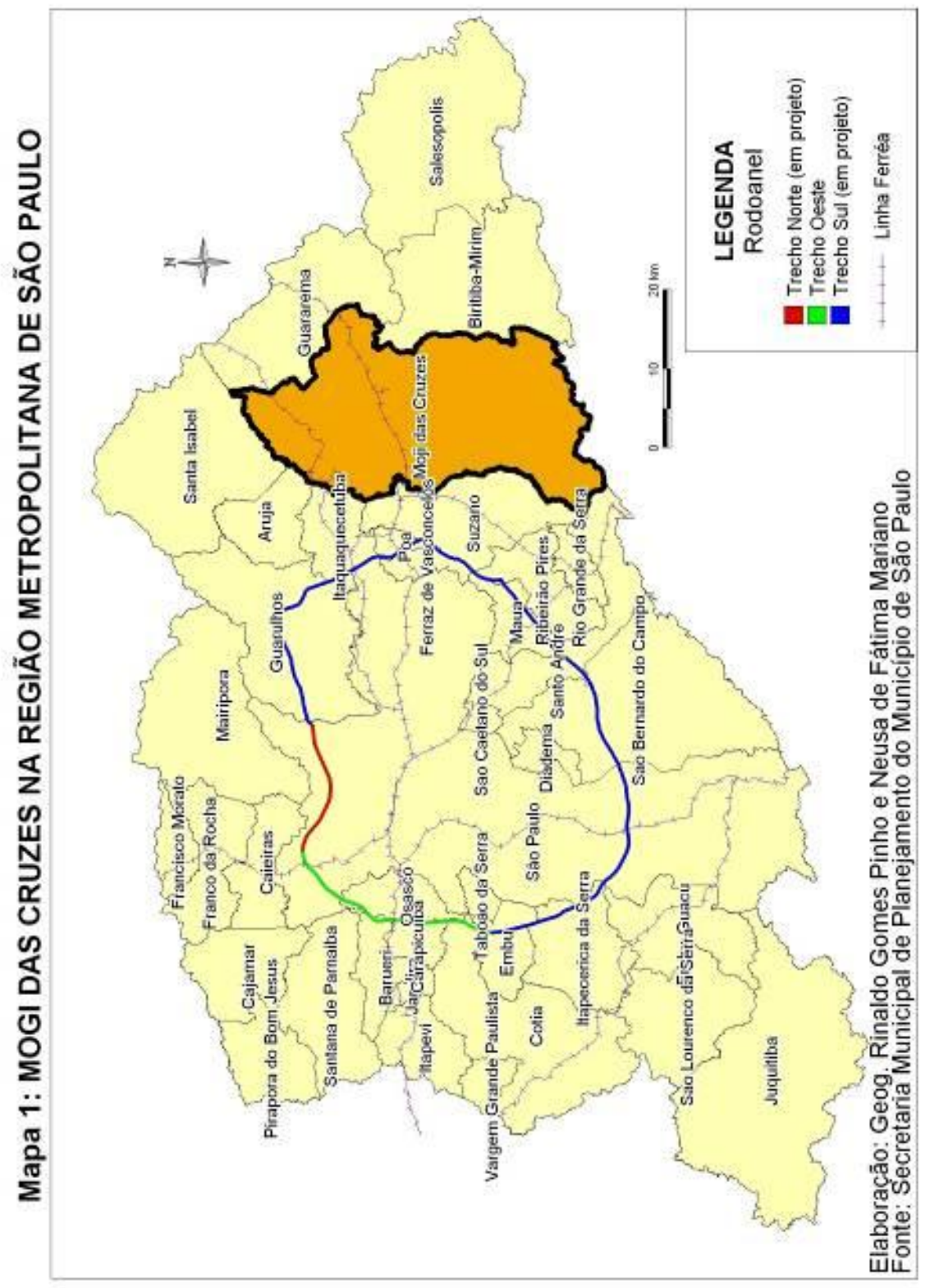

\section{pdfMachine}

\section{A pdf writer that produces quality PDF files with ease!}

Produce quality PDF files in seconds and preserve the integrity of your original documents. Compatible across nearly all Windows platforms, simply open the document you want to convert, click "print", select the 
Os empresários foram desta forma, atraídos para Mogi das Cruzes que já contava com a Fábrica de Doces e Conservas, da firma Charles Hü \& Cia, e passou a ter, segundo o Almanak Laemmert (apud GRINBERG, 1961: 117): Fábrica de Chapéus, de M. Vilela \& Cia.; Fábrica de Cervejas e Licores e Fábrica de Sabão, ambas de Anacleto Rosas \& Cia.; Fábrica de Peneiras de Arame e Dobradiças de Germano Kulben; Fábrica de Cortume e Couros, de João Belda. Foi também construída uma grande indústria de tecidos, organizada pela Sociedade Industrial Mogiana.

Com a instalação destas fábricas, o comércio se intensificou e a rede viária interna de Mogi das Cruzes também. Bondes, de propriedade privada, passaram a circular, levando os moradores dos locais mais afastados até a estação ferroviária. O setor de serviços começou a se desenvolver na cidade, como os bancos, telégrafo, escolas, postos de gasolina, rádio... Os carros particulares começaram a circular pela cidade. Novas fábricas foram se instalando, principalmente ao longo da via férrea: louças, ladrilhos, móveis, tecidos, papel, calçados, explosivos, mineração, químicos, chá... (GRINBERG, 1961).

A antiga Estrada de Ferro Central do Brasil, ligando São Paulo ao Rio de Janeiro, foi fundamental no processo de industrialização, pois era a via de circulação pela qual a matéria-prima chegava e os produtos das fábricas eram escoados.

Após a Segunda Guerra Mundial, as indústrias começaram a se estabelecer próximas às rodovias, pois a política econômica nacional da década de $1950^{3}$ incentivava investimentos de capital estrangeiro no setor industrial, sobretudo automobilístico. Assim, o transporte ferroviário foi perdendo importância para o rodoviário em todo o território nacional.

Neste período, a Prefeitura de Mogi das Cruzes, mais uma vez, oferecia isenção de impostos a empresários interessados em investir no setor industrial do município, sendo a região, agora servida pela Rodovia Presidente Dutra (BR 116), que liga São Paulo ao Rio de Janeiro, passando próxima a Mogi das Cruzes. Duas décadas depois, foi inaugurada a Rodovia Mogi-Dutra (SP 88), facilitando o acesso do interior do município à rodovia federal. A Rodovia Estadual Ayrton Senna (SP 70, antiga Trabalhadores), que corta Mogi das Cruzes ao norte, foi inaugurada na década de 1980 (Mapa 2).

3 Governo de Iuscelino Kuhitschek 
Mapa 2

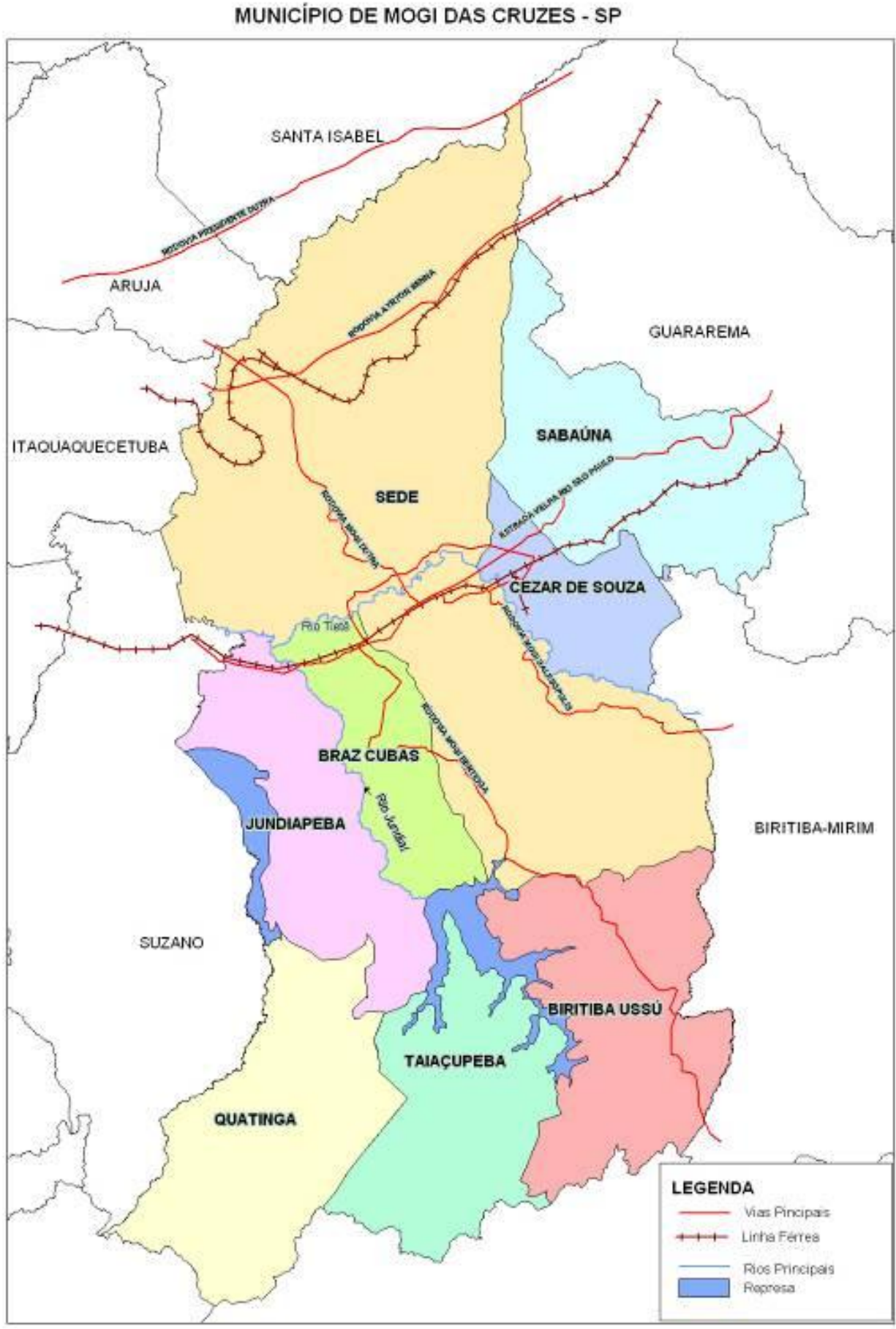

pdfMachine

A pdf writer that produces quality PDF files with ease!

Produce quality PDF files in seconds and preserve the integrity of your original documents. Compatible across nearly all Windows platforms, simply open the document you want to convert, click "print", select the

"Broadgun pdfMachine printer" and that's it! Get yours now! 
A porção do município servida por estas rodovias, constitui-se em uma ZUPI Zona de Uso Predominantemente Industrial, onde hoje se encontra instalada, dentre várias outras empresas, uma unidade da General Motors.

Assim, pode-se dizer que houve, ao longo da segunda metade do século XX, a intensificação de um modo de vida urbano, induzido pela industrialização.

Embora pertencendo ao grande complexo metropolitano de São Paulo, Mogi das Cruzes guarda muitos aspectos rurais no seu cotidiano, não apenas por possuir extensas áreas rurais, mas também por apresentar manifestações da cultura popular que, ao que tudo indica, carregam ainda traços característicos de um modo de vida rural.

Alguns desses aspectos podem ser encontrados com facilidade em práticas tradicionais da religiosidade popular, como a Festa do Divino Espírito Santo, realizada há quase dois séculos na cidade de Mogi das Cruzes. Trazida pelos colonizadores portugueses ao Brasil, a Festa é, hoje, gerenciada por uma Associação - a Associação Pró-Festa do Divino - que a "ajusta" à realidade urbana na qual se insere.

Tal fato nos leva a refletir sobre a relação entre o rural e o urbano hoje, uma vez que o primeiro emerge no segundo, entre outros momentos, durante as celebrações da religiosidade popular. Ou seja, um modo de vida urbano interpenetrado por costumes do passado; relações sociais, políticas e econômicas próprias da modernidade, convivendo com relações de caráter mais pessoal, próprias das comunidades rurais.

Por enquanto, pode-se afirmar que a Festa do Divino Espírito Santo de Mogi das Cruzes, ao mesmo tempo em que representa o passado na forma de festejo tradicional, circunscreve-se no espaço urbano com toda a sua complexidade. A própria festa se moderniza na sua organização que implica divisão de trabalho, administração das finanças, divulgação pela mídia, entre outros aspectos. A festa se moderniza ainda mais quando os números passam a ter papel importante. Há uma preocupação contábil, que parece representar o seu sucesso (números de participantes, de carros de bois, de "grupos folclóricos", de matérias nos jornais, de voluntários, de dinheiro arrecadado, etc.). Para tanto, as parcerias com empresas privadas tornam-se fundamentais, pois estas garantem, além da realização da Festa, a sua divulgação e, em conseqüência e, logicamente, a divulgação das próprias empresas. A Festa, na verdade, se atualiza na dinâmica da sociedade urbana, incorporando novos valores, ajustando e/ou eliminando os antigos. É a Festa dos novos tempos que se redefine a cada ano, cada vez mais se integrando à lógica do 
mercado.

Santos (1998: 20), estudando as festas religiosas realizadas em Irai, no estado de Minas Gerais, contribui para a reflexão aqui proposta ao dizer que

Essas festas, como eram, não existem mais. No entanto, existem redefinidas. Sua sobrevivência tem que ser entendida como esforço, como estratégia, como redefinição, como invenção que procura reunir diferentes produtores, várias divindades e dar outros sentidos à sua manutenção.

E ainda: "Nessa recriação não é raro reivindicá-las como espetáculo".

A Festa do Divino Espírito Santo de Mogi das Cruzes, ao se redefinir, torna-se espetáculo, o formato que a possibilita se manter. Isso significa dizer que a tendência à expropriação de uma manifestação religiosa popular se faz presente e forte, pois os investimentos e o consumo da festa como mercadoria se destacam.

\section{Sobre Geografia, cultura, e festa}

Para refletirmos sobre a problemática aqui apresentada, é fundamental nos apoiarmos nos estudos sobre cultura, o que pode causar certo estranhamento quando se trata de uma pesquisa na área da Geografia. No entanto, a cultura sempre foi tema pertinente aos estudos geográficos, pois autores clássicos como Ratzel, Vidal de La Blache e Max Sorre já demonstravam preocupação com a visão de mundo e o modo de vida de determinados povos em determinados lugares.

Com a Antropogeografia e a Moderna Geografia Científica, no início do século XX, Ratzel procurou superar a abordagem meramente descritiva - que deveria ser meio e não fim - até então dominante nas ciências geográficas. Situa o homem no centro das preocupações da Geografia, levando em consideração, para sua análise, as formas de vida no meio físico, ou seja, o ambiente em que vive o grupo humano a ser estudado. Desta forma, seria possível entender a organização social, o Estado, o território, com base no espaço natural ou meio físico.

Vidal de La Blache (1911) defende que o homem pode intervir na natureza, e não está tão sujeito às condições naturais como dizia Ratzel. Ao desenvolver o conceito de "gênero de vida", La Blache defende que a ocupação humana, de uma determinada área, 
interfere na sua fisionomia e na sua ordem natural, tendo como resultado uma verdadeira integração do homem com a natureza. O gênero de vida - na condição de categoria geográfica e um dos sustentáculos da Geografia Humana - permitia explicar, então "a grande diversidade cultural relacionada à variedade do meio natural” (MAIA, 2000: 128). Ainda para La Blache, o solo tem grande importância no gênero de vida, pois ele é diferenciado nos lugares, apresentando especificidades as quais sugerem usos diferenciados pelos povos.

Para Max Sorre (década de 1940), os estudos de gênero de vida abrangem a análise dos elementos materiais e espirituais, os quais entende como "[...] técnicas transmitidas pela tradição, mediante as quais os homens asseguram seu domínio sobre a natureza.” E ainda: "[...] cada técnica material se desdobra numa técnica religiosa [...]". (SORRE, 1984: 100).

Com preocupação voltada, até então, a grupos que tinham relação direta com a natureza, exercendo atividades agrárias e extrativas, o problema em sua análise surge quando Sorre se depara com grupos mais independentes do meio físico, como os que vivem do trabalho nas indústrias. Amplia, então, o conceito de "gênero de vida" para "gênero de vida urbano", de modo a abranger as sociedades industriais, consideradas mais complexas que as agrárias.

As preocupações com relação à cultura, nas pesquisas geográficas, começaram a ganhar maior evidência nas primeiras décadas do século XX, com os estudos, entre outros, de Carl Sauer.

Este autor se opunha ao positivismo e ao determinismo ambiental até então dominantes, e se opunha também ao pensamento crítico sob a perspectiva do materialismo histórico e dialético. Com base no historicismo, indica os pontos básicos do seu pensamento: descrição, comparação, generalização, subjetividade e relativismo metodológico, contemplação, compreensão, preocupação com o passado, tradicionalismo, moralismo, liberdade e valorização da estética (SPETH, 1987 apud CORREA, 2001: 13). Ao sair do mundo determinista ambiental, Sauer direcionava-se ao outro extremo, ao mundo do determinismo cultural que, segundo Correa (2001) seria uma versão do darwinismo social (evolucionista), o mesmo que o próprio Sauer criticava.

Estava nascendo uma nova linha de pesquisa na Geografia, a Geografia Cultural. Conforme Wagner e Mikesell (2000: 112), a Geografia Cultural tem por objetivo 
[...] identificar aspectos ambientais característicos de uma determinada cultura e, se possível, descobrir que papel a ação humana desempenha ou desempenhou na criação e manutenção de determinados aspectos geográficos. A geografia cultural distingue, descreve e classifica os complexos típicos de aspectos ambientais, incluindo aqueles feitos pelo homem, que coincidem com cada comunidade cultural [...].

Segundo Claval (2001), a Geografia Cultural é limitada porque descritiva, sem preocupação com as relações entre os sujeitos. Somente em fins de 1950 deu-se início ao processo de modernização da Geografia Cultural, a partir da abordagem das decisões humanas com inspiração econômica, com atenção voltada para a racionalidade das atividades.

Na década de 1970, pesquisadores observavam que faltava na análise da Geografia Cultural, considerar que a vida e as atividades dos grupos humanos "são expressão de processos cognitivos, de atividades mentais, de trocas de informação e de idéias" (CLAVAL, 2001: 39). Desta forma, as sensações e as percepções tornavam-se fundamentais, mudando o foco da questão: do inventário de artefatos e descrição de atividades que davam a um grupo uma identidade, para o homem e a sua interpretação do meio em que vive ou visita.

A ênfase, na linha de pesquisa que veio a se chamar Nova Geografia Cultural, está agora na percepção que o homem tem do meio, diferenciando-se as relações a partir do momento em que as pessoas associam, ao mesmo lugar, sentimentos e atitudes diferenciadas. Assim, conforme Claval (2001), o foco está também nas práticas e habilidades não verbalizadas, resultantes de uma atividade mental. A experiência é relevante na análise, pondo em evidência o corpo, portador de diferentes idades, sexos, visões, olfatos, audições, etc.

A Nova Geografia Cultural instiga a analisar as experiências humanas diversas no espaço, a partir do próprio corpo nas suas relações com o ambiente, chegando às categorias mentais construídas e que servem para organizar tais experiências, pois é preciso explicar "a natureza dos grupos sociais e suas formas de organização espacial" (CLAVAL, 2001: 61). Assim, tornam-se fundamentais, conforme Claval (2001), para o desenvolvimento da abordagem da Nova Geografia Cultural, a identidade, a territorialidade e a comunicação sem restringir-se à descrição, mas percebendo a dinâmica social.

Os estudos sobre a cultura não podem limitar-se à descrição, tampouco limitar-se a buscar, única e exclusivamente, o simbólico, as sensações, as percepções, a identidade. Os 
estudos da cultura no espaço urbano nos remetem às relações sociais, aos agentes transformadores do espaço, aos conflitos envolvidos no processo de modernização da sociedade.

Cabe apontar para as interfaces presentes quando se trata de pesquisa sobre elementos culturais que se manifestam num dado espaço geográfico, socialmente produzido e reproduzido. Estamos nos referindo às interfaces, desde há muito tempo existentes, entre a Geografia e outras ciências humanas, principalmente a Antropologia e a Sociologia ${ }^{4}$, sem esquecer a História.

Portanto, embora a abordagem proposta pela Nova Geografia Cultural seja, hoje, referência para muitos estudos geográficos que trazem a cultura no seio de suas preocupações, ela restringiria a análise. A presente pesquisa propõe-se a examinar a Festa do Divino Espírito Santo de Mogi das Cruzes enquanto manifestação da cultura popular nas suas relações com a sociedade mais ampla no seu processo de modernização. Propõe-se, especialmente, a analisar a festa enquanto elemento constitutivo do espaço urbano ${ }^{5}$.

Em linhas gerais, a presente pesquisa pretende analisar a Festa do Divino Espírito Santo de Mogi das Cruzes através de uma abordagem geográfica dessa manifestação cultural, sem, no entanto, trilhar os caminhos da Nova Geografia Cultural, mas partindo de uma reflexão sobre a produção do espaço social, compreendendo uma manifestação de religiosidade popular como elemento da sociedade mais ampla, ambas em transformação.

Como a abordagem da festa hoje não pode desconsiderar sua inserção na sociedade urbano-industrial, deparamo-nos com algumas questões: como entender a Festa do Divino Espírito Santo, cuja gênese se esconde numa sociedade eminentemente rural, na sua inserção urbana? Qual o sentido (ou quais são os sentidos) da Festa do Divino Espírito Santo para aqueles que dela participam (desde os que a dirigem e a preparam, até os simples espectadores)?

\footnotetext{
${ }^{4}$ Vivemos hoje uma fragmentação das ciências, com as especializações, que as distanciam cada vez mais. Mas a compreensão do problema que se propõe em uma pesquisa só é possível a partir de uma visão de totalidade, segundo a qual as partes pertencem a um todo e só têm sentido em relação a esse todo.

${ }^{5}$ Procurando um aprofundamento na compreensão do papel da cultura na sociedade moderna, sem perder de vista o objeto da Geografia, recorremos a Henri Lefebvre, cuja contribuição para a compreensão das relações entre sociedade e espaço é inquestionável. Para este autor, a produção e a reprodução do espaço (social) resultam da práxis social, ao mesmo tempo em que a determinam, ou seja, o espaço social é produto e condição da práxis (LEFEBVRE, 1974). Nesta pesquisa, o espaço
} 
Uma das hipóteses que orientam a presente pesquisa considera a Festa como resíduo $^{6}$, ou a existência de resíduos na Festa, de relações ainda não capturadas pelo mercado e que, em períodos de não-Festa se mantêm em "segredo" no cotidiano. A Festa do Divino Espírito Santo aparece como mediação para o encontro, que não é um simples encontro: é trabalho conjunto, é solidariedade, é a reunião para a realização de algo. Nos dias atuais, a Festa traz consigo a possibilidade de constituição de uma sociabilidade mais rica que aquela dominante na sociedade contemporânea, mediada pela mercadoria, embora as relações de mercado tendam a restringir cada vez mais essa possibilidade.

A tradução brasileira de Metafilosofia, obra de Henri Lefebvre, editada em 1967, traz uma apresentação na qual Rolando Corbisier (tradutor) procura esclarecer a concepção de resíduo contida nessa obra. No mundo fragmentado algo resiste e não se deixa reduzir:

O que resiste, o que fica de fora dos sistemas, das estruturas, é o resíduo, para Lefebvre, ponto de partida, o despertar, e a mobilização do resíduo a esperança de uma metamorfose do quotidiano. (CORBISIER, in: LEFEBVRE, 1967: 53).

Essa fragmentação do mundo diz respeito à transformação pela qual a sociedade vem passando, principalmente a partir da chamada Revolução Industrial (século XVIII), com o emprego de novas técnicas e tecnologias, divisão cada vez mais avançada do trabalho, e super exploração da força de trabalho, bem como a imposição da lógica da produtividade sobre a sociedade. $\mathrm{O}$ avanço do processo de industrialização provocou a fragmentação da vida cotidiana. A relação conflituosa entre o homem e a natureza está cada vez mais submetida à mediação do capital, para sanar as necessidades do homem (LEFEBVRE, 1979: 31), tanto as vitais para a reprodução da vida, como as "inventadas" pelo próprio mercado industrial. O valor de troca se sobrepõe ao valor de uso, o que provoca a perda do sentido e da totalidade da obra, enquanto única, insubstituível, criada pelo homem através da prática social.

A criação (da obra), conforme Lefebvre (1967) liga-se no que ele designa poièsis ${ }^{7}$,

urbano é compreendido como produto e produtivo da sociedade, mas também espaço de possibilidades, espaço de encontros e desencontros de tempos e de relações.

${ }^{6} \mathrm{O}$ conceito de resíduo será melhor explicitado a seguir.

${ }^{7}$ Segundo Lefebvre (1979: 34, grifo do autor):

A poièsis dá forma humana ao sensível; compreende as relações com a natureza, os trabalhos agrícolas, artesanais, artísticos e, de modo geral, a apropriação da natureza por parte do homem social em torno dele e dentro dele mesmo. A praxis pdfMachine A pdf writer that produces quality PDF files with ease!

Produce quality PDF files in seconds and preserve the integrity of your original documents. Compatible across nearly all Windows platforms, simply open the document you want to convert, click "print", select the "Broadgun pdfMachine printer" and that's it! Get yours now! 
a qual dominava a praxis (atividade social) na sua totalidade e que, na sociedade capitalista, se encontra como resíduo, presente na mimésis (imitação). Para esclarecer seu pensamento, Lefebvre exemplifica com a cidade:

Constatamos uma diferença fundamental (datando da fundação ou do fundamento) entre a polis [grega] e a urbs [romana]. Nesse período, o dizer e o fazer, ainda, não se separavam. Nomear e designar o nascente para que crescesse era um ato. A solenização religiosa e os ritos de fundação não eram encenação, mas maneira de aceitar os riscos da situação criada, de comprometer-se a manter a obra nova, a eternizá-la e a eternizar-se nela. O sagrado, antes de institucionalizar-se, bem antes de tornar-se atitude e comédia, e de justificar a apropriação privativa pelos senhores da obra comum a todo o povo, acompanhava a fundação. $O$ fundador, $\mathrm{o}$ fundamento, o fundado discerniam-se mal. (LEFEBVRE, 1967: 214).

Segundo Lefebvre, o resíduo é, ele próprio, criação, a esperança da transformação, pois "o resíduo manifestado torna-se [...] o essencial, mais bem percebido e valorizado após a sua redução [...]. A diversidade dos resíduos e seu caráter residual só tem sentido nos e pelos sistemas que tentam reabsorvê-los”. (LEFEBVRE, 1967: 373).

Com a reflexão sobre os resíduos e seu potencial transformador, Lefebvre inclui-se entre aqueles pensadores que, segundo Michel Löwi, representariam um novo romantismo ou o romantismo revolucionário, ou ainda, se se quiser, o marxismo romântico. Superando o velho romantismo caracterizado pela forte nostalgia de tempos antigos, o novo romantismo implica a contradição e envolve, ainda que virtualmente, a revolta, conferindo-lhe um caráter antiburguês e subversivo (LÖWI, 1991: 6).

Para Löwi (1999) o romantismo está presente na arte, na literatura, etc., mas tem como característica principal a crítica à sociedade burguesa moderna. Ao se referir aos estudos de José Carlos Mariàtegui, Löwi destaca que neles o romantismo tem o seu cerne no sistema produtivo, uma vez que ele vislumbra um socialismo (a partir de uma visão revolucionária) que tem como base, tomando o caso peruano, "tradições comunitárias do campesinato andino, os vestígios do comunismo incaico [...].” (LÖWI, 1999: 43). Ou seja, uma concepção moderna do novo romantismo busca, na tradição mais antiga e profunda do mundo agrário, elementos residuais propiciadores de uma transformação radical da sociedade moderna, sem que isso signifique um retorno ao passado. Pelo contrário, o

atividades diretivas, as funções estatais, na medida em que se vão constituindo. Em sentido amplo, a praxis envolve a poièsis; em sentido restrito, ela se limita, determinando-se, designando apenas os pragmata, tarefas deliberadas entre seus mambroce a cociedade 
romantismo revolucionário direciona a sua visão para um futuro utópico, para o devir. Neste sentido, Bloch, também considerado marxista romântico, apresenta-nos o "princípio esperança". Ao tratar da festa, do lazer, do passa-tempo ou ainda, do lúdico, Bloch (2006: 459) considera que há uma parte do homem que não deixa morrer vestígios de lazeres "mais plenamente realizados, datando dos tempos antigos, da época pré-capitalista”, dificilmente incorporados ao capitalismo. Nestes vestígios reside a esperança de um futuro melhor. Portanto, a esperança está na parte do homem que ainda não foi completamente vendida (capturada) - reflexão que nos auxilia na compreensão da concepção de resíduo, de Henri Lefebvre.

No que diz respeito à festa, mesmo que ela se torne produto ou espetáculo, comporta também momentos de plenitude, pela presença de resíduos de tempos pretéritos, de sociabilidades propiciadoras do encontro, da contestação, pois, antes de ser ruptura, a festa é explosão de forças acumuladas no cotidiano (LEFEBVRE, 1958).

Se, hoje, a Festa do Divino de Mogi das Cruzes contém ou se manifesta como resíduo, isto ocorre no tempo livre, em que o lúdico é vivido; assim, ela pode se constituir em uma forma de contestação, uma vez que sua prática nega a possibilidade de ocupação do tempo de não-trabalho por outro trabalho. Mas, é preciso não esquecer que a ordem dominante tende a aniquilar a Festa na medida em que ela se torna instrumento de interesses econômicos.

Hobsbawm (1997) considera as tradições inventadas ou forjadas, as quais foram construídas e até mesmo institucionalizadas, havendo, portanto, o seu estabelecimento, a sua aceitação pela sociedade como um todo. O objetivo das tradições inventadas é inserir na sociedade determinados valores e comportamentos que se institucionalizariam pela prática da repetição, ou seja, pelo costume, estabelecendo "uma continuidade em relação ao passado" (HOBSBAWM, 1997: 10). No entanto, as continuidades seguem o seu tempo e, mesmo que as manifestações façam referência ao passado, estão e se utilizam de elementos e recursos do presente. Assim, podemos pensar na cultura como dinâmica e plástica.

Canclini é outro estudioso que nos ajuda a refletir sobre a cultura na sociedade moderna, através do processo por ele designado de hibridação ${ }^{8}$. Explica o autor, que a hibridação da cultura revela não a sua esterilidade, pelo contrário, a sua fertilidade, pois a 
variedade genética possibilita a sobrevivência de elementos das culturas matrizes, elementos estes presentes na cultura híbrida, resultantes e contribuintes na continuidade do processo de hibridação, pela dinâmica ${ }^{9}$ inerente a ela. Não se trata de cultura dominante que se sobrepõe à dominada mas, antes, de um movimento social que "pede" tal hibridação. Não se trata de miscigenações; trata-se, porém, de o resultado de encontros culturais do passado estar sujeito ao processo de modernização que busca a homogeneização, mas não a alcança. $\mathrm{O}$ tradicional e o moderno não estão, no processo de hibridação cultural, em lados opostos, ao contrário, se alimentam mutuamente (não livres de conflitos).

Pelo exposto, optamos por uma abordagem que contemple as temporalidades diversas presentes na Festa do Divino. O estudo da Festa mostra um movimento que mantém, descarta e incorpora elementos, permanecendo algo que poderia ser o seu cerne, aquilo que dá sentido a ela. A Festa veste-se do passado e do presente, realiza-se por meios modernos, fortalecendo-os. Mas conserva tempos pretéritos, o passado revivido através da memória, o passado vivido ainda no cotidiano, porque transmitido, e revivido nos rituais, por exemplo. Há um passado às vezes escondido e que se mostra à sociedade no tempo presente, sem perder o seu sentido.

Apesar de ser espetáculo e mercadoria, portanto, participar da indústria cultural, a Festa do Divino Espírito Santo de Mogi das Cruzes, também é aqui considerada manifestação popular, comportando momentos de plenitude.

${ }^{8} \mathrm{O}$ autor não se refere ao "híbrido" das ciências biológicas, cujo fundamento está no encontro de duas matrizes diferentes que resultam em um elemento novo, porém estéril, sem condições de se reproduzir.

${ }^{9}$ Ao nos atentarmos para a nossa realidade no processo de modernização, verificamos que não há cultura pura, aquela intocável, imortalizada, sem contato com o mundo, com agentes que possam alterar a sua dinâmica 


\section{O movimento da pesquisa - o método e a metodologia}

Diante da amplitude do tema e da problemática que ele suscita, é preciso se imbuir de um método que possibilite uma visão de totalidade, pois facilmente o pesquisador pode privilegiar determinados caminhos que o levem a uma visão parcelar da realidade. Desta forma, cabe atenção ao processo social, com o intuito de entender o objeto de estudo como um todo contraditório.

Reportamos-nos então, a Henri Lefebvre (1978), que propõe um método de análise que considera as temporalidades. Ao se debruçar sobre os problemas e as perspectivas da Sociologia Rural, o autor indica uma dupla complexidade (vertical e horizontal) que caracteriza a realidade camponesa. A complexidade horizontal corresponde a formações e estruturas agrárias presentes em um mesmo momento histórico, porém com diferenças essenciais, devido ao conjunto de condições que cada estrutura possui. Atribui-se à complexidade vertical a coexistência de formas com diferentes idades e que se originaram em épocas diferentes; o autor exemplifica ao apontar a existência daquilo que é considerado o mais antigo ao lado do que se tem de mais moderno. As duas complexidades são históricas e se encontram, entrecruzam, atuam uma sobre a outra.

No mundo rural, mais claramente ainda do que no artesanato, nada desapareceu completamente. E só o fato dessa conservação dos arcaísmos e dos 'fósseis sociológicos' - conservação relativa, que não exclui as influências, a degenerescência, as integrações mais ou menos bem sucedidas do arcaico a conjuntos recentes - só esse fato suscita inúmeros problemas. (LEFEBVRE, 1978: 64)

Podemos falar, então, em descompassos das relações sociais, com datas, origens e ritmos diferenciados. São temporalidades diversas que se encontram num mesmo momento histórico, expressas nos modos de ser, pensar e agir, e convivem, contraditoriamente, diante do processo de modernização que impõe a lógica do capital (embora essa lógica não chegue a dominar por completo).

Conforme Martins (1996), na concepção de Henri Lefebvre, os desencontros são também de tempos e, por conseguinte, de possibilidades que ainda não se realizaram ${ }^{10}$. Na

${ }^{10}$ Ramos (2001), apoiado em Henri Lefebvre e José de Souza Martins, aborda as espacialidades que pôde apreender em seu estudo sobre a Água Branca, como espaço industrial da cidade de São Paulo,

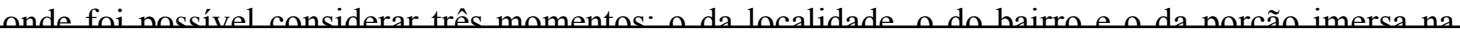


realidade social, há encontros e desencontros, descompassos de tempos e possibilidades de realizações constantes numa dinâmica que provoca confrontos e ajustamentos, alterando, diluindo e/ou dissolvendo determinados elementos de uma sociedade.

Nesta pesquisa, lançamos mão do método regressivo-progressivo, proposto por Henri Lefebvre (1978), que considera a história, fundamental para a análise. Parte-se da realidade tal qual ela nos aparece, tal qual ela pode ser descrita, no plano do fenômeno. Este seria o primeiro momento de investigação, o descritivo, e abrange a coleta de informações, registros de imagens, observação, descrição, etc. O segundo momento do método é o do recuo histórico em busca da gênese do fenômeno. É o momento analítico-regressivo que ganha sentido a partir da realidade como nos aparece (LEFEBVRE, 1978).

Ao retornar ao objeto da pesquisa, ou seja, no terceiro momento do método, o histórico-genético, há o reencontro com o presente, mas agora esclarecido, compreendido e explicado. Então, pode-se ver além das aparências, compreender a realidade social na sua complexidade, à luz da análise teórico-conceitual.

Quanto à metodologia, a pesquisa privilegiou os procedimentos de caráter qualitativo, sem que haja, no entanto, desprezo pelos dados numéricos que vieram a contribuir para a pesquisa. Neste sentido, lançamos mão de procedimentos que foram desde uma investigação histórica - com base em documentos antigos - até o registro da memória, por meio de entrevistas.

Foram realizadas cerca de trinta e oito entrevistas gravadas e, posteriormente foi feita a transcrição e análise das mesmas. Os roteiros das entrevistas foram elaborados a partir das diferentes inserções das pessoas na Festa do Divino ${ }^{11}$. Assim, os roteiros incluíam questões específicas para ex-Festeiros e ex-Capitães de Mastro, coordenadores da Associação Pró-Divino, Padres, Mestres de “grupos folclóricos”, Rezadeiras, etc.

Para a realização das entrevistas, apoiamo-nos, sobretudo, em Queiroz (1991). Segundo esta autora, a entrevista é a forma mais antiga e conhecida para coleta de dados

metrópole. Tendo como referência Henri Lefebvre, ele explica os fragmentos e os resíduos, mostrando que o último momento, ou seja, o da "a porção imersa na metrópole" revela os outros dois: a da localidade e o do bairro. Assim, o presente revela a permanência de elementos do passado, ainda que às vezes escondidos.

${ }^{11}$ Durante os trabalhos de campo foi possível observar variados "personagens" com determinadas funções, o que tornou possível a elaboração de roteiros com questões específicas relacionadas às suas atividades na Eesta do Divino 
orais, que implica um colóquio entre pesquisador e narrador ${ }^{12}$.

O contato com entrevistados foi se estabelecendo durante as Festas que pude acompanhar, desde 2003 até 2006. A relação de confiança que se criou, o orgulho que sentiam por participar de uma Festa que merecia estudo, que interessava a alguém de São Paulo, da Universidade, propiciaram confidências e revelaram, às vezes pelo silêncio, às vezes pelas idéias apenas insinuadas, suas angústias com relação ao grupo a que pertenciam, ou com a própria Festa.

Pesquisa exaustiva foi feita no jornal O Diário de Mogi, que traz notícias da Festa do Divino desde 1960, ano de sua fundação. A partir dos dados obtidos, foi possível observar o aumento do destaque dado à Festa até os dias de hoje. Os textos trazem informações referentes às mudanças ocorridas na Festa, seja a introdução de novos elementos como a extinção de algumas práticas, ou ainda, alterações de tantas outras. Os artigos revelaram também que havia a preocupação com as origens históricas da Festa, inclusive as bíblicas.

No Arquivo da Cúria Metropolitana de São Paulo, foi possível encontrar os registros mais antigos da Festa. São as Provisões (autorizações mediante pagamento) para a realização da Festa do Divino, que recuam a 1822. Infelizmente não há descrição da manifestação.

Outro registro da Festa, mas um pouco mais recente, foi encontrado no Arquivo Histórico e Pedagógico de Mogi das Cruzes, e data de 1899. Trata-se de matéria do jornal O Ypiranga: uma pequena nota com uma breve descrição. Assim, juntamente com material bibliográfico e entrevistas, foi possível fazer uma certa reconstituição histórica da Festa do Divino de Mogi das Cruzes que, embora longe de esgotar a história da Festa, contribuiu para o entendimento desta manifestação hoje.

Com base em material da Prefeitura Municipal de Mogi das Cruzes $^{13}$, foram

${ }^{12}$ As orientações da autora foram essenciais no que diz respeito, por exemplo, ao uso do gravador e do caderno de campo. O uso de gravador é uma técnica que auxilia o pesquisador na obtenção de entrevista, com o objetivo de manter a informação viva, apesar de, em alguns momentos, interferir na fala e espontaneidade do entrevistado. $O$ gravador torna-se via necessária não só para o registro do que se disse, mas também para o registro da forma como foi ou como não foi dito, do tom de voz e das pausas, momentos importantes, conforme o objeto da pesquisa. O caderno de campo não pode ser desprezado, pois imediatamente após as entrevistas, é preciso anotar, além das falas não gravadas, impressões, descrições do ambiente, e porventura, interrupções. Tais anotações podem auxiliar na análise das entrevistas, já transcritas, portanto transformadas em documentação escrita e/oudioital 
elaborados os mapas que procuram representar algumas práticas e momentos da Festa cuja espacialização foi considerada relevante.

O trabalho de campo não se esgotou na busca de fontes e coleta de dados. Conforme o tema proposto, a sensibilidade do pesquisador tornou-se fundamental para o desenvolvimento da pesquisa ${ }^{14}$ (sensações, impressões, intuições, percepções, etc.). Portanto, a participação em determinados eventos relacionados ao objeto de estudo, e a observação do comportamento das pessoas permitiram esboçar alguns traços da realidade social em pauta. $\mathrm{O}$ olhar das pessoas, a sua aproximação ou não do pesquisador, a forma como elas se comportavam, se vestiam, falavam, organizavam o pensamento, acolhiam o pesquisador, estão no conjunto de elementos relevantes, pois contribuíram, tanto para o estabelecimento de roteiros como para a análise das entrevistas e, conseqüentemente, para os resultados finais da pesquisa.

Em seguida a esta Introdução, o capítulo A festa e o espetáculo procura discutir o sentido da festa ao longo da História.

O segundo capítulo, Origens das homenagens ao Espírito Santo, trata de elementos fundadores das homenagens ao Espírito Santo, desde os símbolos trazidos da Bíblia Sagrada até elementos oriundos da Idade Média, na Europa, assim como a introdução da Festa do Divino pela Rainha Dona Isabel, em Portugal.

Heranças de Portugal nas festas religiosas populares é o título do terceiro capítulo, que discorre sobre como foram se configurando as festas religiosas no Brasil, enquanto colônia de Portugal, sobretudo a Festa do Divino Espírito Santo.

A análise da Festa do Divino de Mogi das Cruzes, é o conteúdo do quarto capítulo:

\section{Dos primórdios da Festa do Divino de Mogi das Cruzes à sua espetacularização.} Interessa aqui, entender como acontecia o momento festivo no passado de Mogi das Cruzes, quais eram os seus elementos constitutivos, e as suas transformações no decorrer do processo histórico até hoje, quando a Festa se reveste do caráter de espetáculo.

13 Parte do material cartográfico está disponível no site da Prefeitura Municipal: http://www.pmmc.gov.br.

${ }^{14}$ Qualitativamente, a subjetividade é positiva, mas na medida em que o pesquisador tenha auto crítica constante (KOSMINSKI 1009) 
A Festa atual é marcada pela fundação da Associação Pró-Festa do Divino Espírito Santo, que auxilia os Festeiros, no sentido da racionalização da Festa. A Associação atua, inclusive, junto a patrocinadores, o que vem caracterizar significativa mudança na Festa, agora, bastante divulgada pela mídia. Este é o assunto do capítulo A atual Festa do Divino Espírito Santo de Mogi das Cruzes, que mostra a Festa como produto da indústria cultural.

Nas Considerações finais procura-se reunir elementos da Festa do Divino de Mogi das Cruzes que sustentam a hipótese segundo a qual, embora produto da indústria cultural e, portanto, da sociedade do espetáculo, a Festa pode ser compreendida como reunião de resíduos.

Nos Anexos, reunimos orações, canções, um texto sobre a Festa, a programação da Festa do Divino realizada em 2006, e um panfleto de pedido de prendas distribuído nas escolas. 


\section{A Festa e o Espetáculo}

Não apenas os resíduos são o mais precioso, mas roem, destroem por dentro, fazem explodir os sistemas que querem absorvê-los. Nesse sentido, a poièsis, que deles se apodera, deve revelar-se criadora de objetos, de atos e, mais geralmente, de situações.

Henri Lefebvre.

O espetáculo é o momento em que a mercadoria ocupou totalmente a vida social. Não apenas a relação com a mercadoria é visível, mas não se consegue ver nada além dela: o mundo que se vê é o seu mundo.

Guy Debord

A festa, toda festa e qualquer tipo de festa, tão freqüente em nossos dias, muito facilmente pode ser explicada pelo senso comum. Afinal, festa é um momento no qual as pessoas se encontram para celebrar algo: aniversário, casamento, inauguração, etc. Porém, nos perguntamos se e como podemos entender uma festa tradicional popular, superando o senso comum, procurando compreendê-la enquanto fato social.

A festa, na sua gênese, revela a íntima relação do homem com a natureza. Conforme Lefebvre (1958), a natureza propicia o acontecimento festivo através do ciclo regular das estações do ano e, portanto, da boa colheita. O autor remonta à Grécia clássica para dizer que o acontecimento festivo é o momento em que as regras são abolidas, e tudo é permitido no ambiente permeado de fartura de alimentos, que tanto poderiam ser consumidos quanto desperdiçados de forma desmedida. E ainda que a festa tenha o sentido de ruptura com o cotidiano, dele faz parte, pois engrandece seus elementos constitutivos: a alimentação, a relação do homem com a natureza, o trabalho, o encontro.

As festas camponesas fortaleciam os liames sociais e, ao mesmo tempo, desencadeavam todos os desejos recalcados pelas disciplinas coletivas e pelas necessidades do trabalho cotidiano. Na festa, cada membro da comunidade ia, por assim dizer, além de si mesmo e tirava da natureza, da 
alimentação, da vida social, do seu próprio corpo e de seu espírito, de uma só vez, todas as energias, todos os prazeres, todos os possíveis. (LEFEBVRE, 1958: 216).

A festa era um acontecimento coletivo, desde os seus preparativos até o festejar, pois cada comunidade ou aldeia trazia o alimento que era servido a todos os presentes, para celebrar datas de um calendário rústico marcado pelas estações do ano. A natureza, no decorrer do ano, propiciara a fartura, com a chuva e o sol na medida certa; festejava-se em agradecimento, mas também para garantir a continuidade desta fartura. Estar em festa significava a explosão das forças acumuladas pela vida cotidiana (LEFEBVRE, 1958).

A colaboração para a festa, a doação para que a festa acontecesse, caracteriza o sacrifício necessário para que o curso normal da natureza não seja ameaçado por maldições e pragas e, conseqüentemente, pela possibilidade da fome. A natureza, ao mesmo tempo em que é próxima é temível (LEFEBVRE, 1958).

A garantia de uma boa colheita dependia de uma celebração repleta de significados, constituída não só pela abundância de alimentos e bebidas, mas também pela abolição de regras, em que a fertilidade é a garantia de futuro das comunidades e da própria natureza; há aqui uma relação imediata e simples dos camponeses com a natureza, um diálogo é travado, no qual todos se alegram alegrando a natureza, em que todos se fartam alimentando a natureza e se reproduzem na fecundidade da natureza.

Com o processo de diferenciação social e de progresso técnico, ao longo do tempo histórico, as comunidades entraram em crise, tornando cada vez mais frágil a relação imediata com a natureza.

E na própria vida, na vida cotidiana, gestos antigos, ritos imemoriais, perpetuam-se inalterados; ainda que esta vida tenha sido despojada de sua beleza. Restam a poeira das palavras, os gestos mortos. Ritos e sentimentos, preces e fórmulas mágicas dos votos e das maldições, tornaram-se abstratos porque destacados da vida, portanto, "interiores", como se diz no vocabulário das justificações. As conviç̧ões são menos fortes, os sacrifícios menos profundos, menos ardentes. Vivemos - mal com menos gastos. As alegrias são cada vez menos fortes. Apenas não diminuiu a antiga inquietação, o sentimento de fraqueza, o pressentimento do risco e do perigo. Essa antiga inquietação tornou-se preocupação, angústia. A religião, a moral, a metafísica não passam de festas "espirituais" e "interiores" da angústia humana, os canais para os quais dirigimos (para que abismos?) essa vaga negra da ansiedade. (LEFEBVRE, 1958: 227-228). 
Nesse processo, a Igreja se apoderou das festas consideradas pagãs, transferindo o poder e os atributos da natureza a um Deus Supremo; não é mais a natureza que dá o alimento, mas Deus que permite a ela tal atributo. É a Deus que os homens devem agradar. A festividade passou da ordem da natureza para a dos santos, unindo o calendário católico ao agrário, unindo o sagrado ao profano. Explica Thompson (1998: 51):

Em geral, o clero que exerce suas funções pastorais com desvelo sempre encontra maneiras de coexistir com as superstições pagãs e heréticas de seu rebanho. Por mais deploráveis que essas soluções de compromisso pareçam aos teólogos, o padre aprende que muitas das crenças e práticas do "folclore" são inofensivas. Se anexados ao calendário religioso anual, podem ser assim cristianizadas, servindo para reforçar a autoridade da Igreja. [...] O mais importante é que a Igreja devia, nos seus rituais, controlar os ritos de passagem da vida pessoal e anexar os festivais populares a seu próprio calendário.

A Igreja, ao permitir alguns elementos (os considerados "inofensivos") das manifestações festivas pagãs, foi caracterizando-os como "folclóricos". Da união entre o sagrado e o profano, nasceram as festas religiosas populares com caráter folclórico.

As necessidades e satisfações, as realizações e conquistas humanas são atribuídas às relações estabelecidas com um plano "superior", em que uma comunicação é estabelecida a partir da interpretação de símbolos e sinais. Neste sentido, há uma interpenetração do profano no mundo do sagrado e vice-versa; as reverências pagãs à natureza voltavam-se agora, a um Deus, aos santos, etc., mas continuavam pagãs, passando a ser entendidas como folclóricas. E o folclore, por sua vez, é aqui considerado parte constitutiva da cultura popular, pois nasce no seio do povo.

Os símbolos e representações que estas festas comportam, unidos à esfera material (de reprodução da vida), implicam, segundo Bosi (1992), a totalidade do "homem rústico", sem erudição.

Para o autor (1987: 123), a cultura popular "é a cultura que o povo faz no seu cotidiano e nas condições em que ele a pode fazer". Por isso, a cultura popular não morre, pois seu agente é o povo, que saberá gerir as condições necessárias para a manutenção da expressão do grupo ou comunidade. Assim, a permanência de determinados elementos ligados à religiosidade, às crendices, às festas, etc., possui raízes históricas que mantém seu sentido na atualidade, porque vivida no cotidiano, oferecendo à cultura caráter de tradição e de obra. 
A festa popular explode na exuberância do folclore; é ela o mais leve dos divertimentos, a mais pura das alegrias recreativas que se torna pública. $\mathrm{O}$ seu aspecto exacerbado (alimentos, bebidas, alegria, liberdade, sonhos e desejos, etc.), contrasta com a miséria, que, junto com a melancolia e o tédio, é característica das festas burguesas (BLOCH, 2006).

As festas populares, por seu turno, não denotam artificialidade [...]. Na verdade falta aqui convincentemente a dimensão pastoril, o posado elemento arcádico, agregando-se em troca o ingênuo, o arcaico, uma parcela do último convívio de Dionísio. Dionísio é um Deus que libera, de maneira que sua festa popular já agora se revelou útil para uma reprogramação, de forma alguma clerical. Esse mundo de feriados celebra alegrias, para as quais de fato surge um verdadeiro motivo apenas mais tarde, a saber: antecipa-se a libertação do povo. (BLOCH, 2006: 461-462).

A artificialidade da festa se apresenta quando ela é descolada de seu sentido e de seu fundamento, em que o que importa é a aparência e não a alegria espontânea que a festa popular possui. A festa da elite assenta-se na ostentação, característica que tende a dominar tudo o que na festa é e pode ser realmente vivido.

A economia de mercado provocou a dissociação do homem com a natureza (que se aprofunda continuamente), com a sua obra, na medida em que avançam os processos de industrialização e urbanização.

O dinheiro e a mercadoria passaram a mediar as relações sociais. Induzida pela industrialização, a urbanização cada vez mais acelerada provocou a "implosão-explosão" da cidade, provocou a sua fragmentação, gerou várias centralidades, produziu também a fragmentação da vida cotidiana, em tempo de trabalho, tempo livre tempo dedicado à vida privada. O tempo livre passa a ser preenchido cada vez mais por mais trabalho e pelo consumo (que pode ser consumo dos lazeres, mediado pelo capital), restringindo-se crescentemente o lugar do lúdico, da festa.

$\mathrm{Na}$ era industrial ${ }^{15}$, necessidades novas são constantemente criadas, dentre elas, as de caráter cultural. Assim, a indústria cultural faz da obra (criação), produto.

Recorremos a Lefebvre (1967) para a discussão da obra e do produto. A obra implica criação (é única), e o produto é destinado à reprodução (imitação) em grande quantidade visando o mercado. Retomando a discussão, já iniciada na Introdução deste

${ }^{15}$ Lefebvre (1972) propõe uma periodização do tempo histórico em eras agrária, industrial e urbana, embora nã ahsolutize esta divisão 
trabalho, das noções de poièsis e mimèsis tal como desenvolvidas por Henri Lefebvre, sobretudo na sua obra Metafilosofia, lembramos que para este autor, poèsis significa a criação de obras, porém nem toda criação é poièsis, é

[...] atividade humana enquanto se apropria da "natureza" (phisys) em torno do ser humano e nêle (sua própria natureza: sentidos, sensibilidade e sensorialidade, necessidades e desejos, etc.). A poièsis é, portanto, criadora de obras. Compreende fundações, decisões de conseqüências, embora às vezes despercebidas durante longos períodos. Nem toda criação é, portanto, poèsis, mas toda poièsis é criação. (LEFEBVRE, 1967: 65, grifo do autor).

Aspecto sociológico no nível da práxis, a mimèsis está entre a repetição e a invenção revolucionária, trazendo latente a sua capacidade criadora, ou poiètica. Ou seja, o que é produto, portanto mimèsis (imitação), carrega consigo um potencial de transformação revolucionária; este potencial é chamado poièsis.

Interessa-nos, neste momento, a relação que se estabelece entre a cultura popular e a indústria cultural.

Para Bosi (1992: 322), não se pode exigir da indústria cultural o que ela não quer oferecer à sociedade: “[...] lições de liberdade social e estímulos para a construção de um mundo que não esteja atrelado ao dinheiro e ao status". A cultura popular, segundo Bosi (1987), é passível de ser considerada mercadoria, quando apropriada pela indústria cultural; torna-se algo que se possui, mas não deixa de ser, por isso, algo que se herda, porque é do povo.

Canclini (2006: 22) observa que é preciso se preocupar menos com o que se extingue na cultura popular do que com o que se transforma, porque se torna mercadoria. $\mathrm{O}$ exemplo está nas atividades dos artesãos, na difusão da música popular e do folclore, que hoje, fornecem trabalho às populações indígenas e camponesas, atraindo turistas e consumidores urbanos.

A modernização diminui o papel do culto e do popular tradicionais no conjunto do mercado simbólico, mas não os suprime. Redimensiona a arte e o folclore, o saber acadêmico e a cultura industrializada, sob condições relativamente semelhantes. O trabalho do artista e do artesão se aproximam quando cada um vivencia que a ordem simbólica específica em que se nutria é redefinida pela lógica do mercado. Cada vez podem prescindir menos da informação e da iconografia modernas, do desencantamento de seus mundos autocentrados e do reencantamento que a espetacularização da mídia propicia. (CANCLINI, 2006: 22). 
O tradicional e o moderno não estão em oposição, fundindo-se muitas vezes, no processo que Canclini (2006) denomina hibridação, o qual surge na vida cotidiana a partir do desenvolvimento tecnológico. A cultura híbrida é gerada nas misturas interculturais modernas, originadas das indústrias culturais, mas não somente delas, que expropriam do popular o artesanato, as músicas tradicionais, etc., e os transforma em produtos de empresas turísticas e de comunicação (CANCLINI, 2006: XXX-XXXI).

Algo permanece nas manifestações culturais, através de costumes e tradições, algo que não se deixa cooptar pela sociedade urbano-industrial ${ }^{16}$.

Para Bloch:

[...] também no feriado arruinado pelo capitalismo ainda existem locais semiprotegidos. Ainda vive uma fração ou um fragmento humano não totalmente comercializável, não completamente prestável como negócio de reprodução. E nele se conservaram de tempos mais antigos, précapitalistas, determinados resíduos do lazer pleno, dignos de ser levados em conta, e eventualmente adaptados sob condições modificadas. (BLOCH, 2006: 459).

Para Lefebvre, no resíduo está o germe do despertar, a esperança para a transformação da sociedade (CORBISIER in LEFEBVRE, 1967).

${ }^{16}$ Para Ortiz (1999), mesmo industrializada, a festa popular não passa a ser inteiramente mercadoria, norawe encerra em si wm "valor de wso" inerente à cua manifectacão 


\section{As Origens das Homenagens Ao Espírito SANTo}

No catolicismo, o Espírito Santo é a terceira pessoa da Santíssima Trindade (Pai, Filho e Espírito Santo), sendo considerado o sopro da vida. Assim consta em Gênese $(2,7)$, no Antigo Testamento ${ }^{17}$ : "Javé Deus plasmou o homem, pó da terra, insuflou em suas narinas um sopro de vida, e o homem se tornou um ser vivo".

Desta forma, deu-se a "intromissão" do Espírito Santo que originou a vida, através do sopro de Deus (ETZEL, 1995). Mas é no Novo Testamento que o Espírito Santo ganha maior visibilidade, pois na liturgia cristã, celebra-se a Sua manifestação em forma de "línguas de fogo" aos apóstolos e à Virgem Maria no dia de Pentecostes - cinqüenta dias após a ressurreição de Cristo (Páscoa cristã), assim como Jesus havia anunciado (ATOS DOS APÓSTOLOS, 1,$8 ; 2,1-4)^{18}$. Uma pomba branca representa o Espírito Santo, porque foi nesta forma que Ele batizou Jesus Cristo (EVANGELHO SEGUNDO SÃO JOÃO, 1, $31-34)^{19}$.

Para os judeus, conforme Araújo (2005), Pentecostes é o dia em que se celebra a colheita realizada cinqüenta dias após a chagada de Moisés com seu povo na Terra Prometida; são as primícias oferecidas em agradecimento a Deus pela terra e pela colheita farta.

Javé falou a Moisés, dizendo: "Fala aos filhos de Israel: quando tiverdes entrado no país que eu vos dou, e tiverdes cortado sua ceifa, levareis ao sacerdote um punhado das primícias de vossa ceifa. Ele apresentará esse

${ }^{17}$ BÍBLIA. Mensagem de Deus. São Paulo: Editora Santuário; Edições Loyola, 1994. p. 22.

${ }^{18}$ Ibidem: p. 1126-1127.

19 Ihidem. n 1007 
punhado diante de Javé para atrair sobre ele sua complacência; o sacerdote o apresentará no dia seguinte ao sábado. (LEVÍTICO, 23, 9-11) ${ }^{20}$.

A partir do dia seguinte ao sábado, do dia em que tiverdes levado o punhado para ser apresentado, contarei sete semanas inteiras. Contareis cinqüenta dias até o dia seguinte ao sétimo sábado e oferecereis a Javé uma oblação nova. Levareis de vossas casas dois pães para a oferta apresentada; serão feitos com sete litros de flor de farinha e cozidos com levedo; são as primícias oferecidas a Javé". (LEVÍTICO, 23, 15-17) ${ }^{21}$.

Talvez estivesse na celebração judaica, a razão para a fartura presente na Festa do Divino Espírito Santo que conhecemos hoje. No entanto, somente tal explicação para a comensalidade, seria muito simplificada. Acredita-se que esta fartura deva ter um fundamento outro baseado em costumes antigos, e faça parte de um conjunto de elementos que compõem a Festa do Divino ainda hoje. A Festa traz muitas representações para além da Bíblia, como o Império do Divino, o Cetro e a Coroa, o Imperador do Divino, etc., que remetem a uma realeza européia e que aparecem junto com os símbolos litúrgicos: a pomba branca sendo o próprio Espírito Santo, a cor vermelha nas bandeiras representando as "línguas de fogo", os sete dons do Espírito Santo, atribuídos pelo apóstolo Isaías ${ }^{22}$.

Retornemos ao século X, durante o domínio germânico na Europa, sob a dinastia cristã dos Othons (quatro reinados, de 936 a 1218). Naquela época os governantes praticavam os "vodos", que consistiam em dias festivos com distribuição de comida aos pobres, o que levou à constituição de uma espécie de banco de esmolas, as quais ajudariam aos necessitados nos anos de maior penúria. $\mathrm{O}$ aspecto da distribuição dos alimentos era festivo e ostentatório visto se tratar de uma atividade da realeza, a protagonista da caridade. (LIRA, 1950 apud PIAZZA, 1953: 32). Os "vodos" poderiam ocorrer também por ocasião de algum culto no cemitério ou no interior das igrejas (ETZEL, 1995).

Nos séculos XIII e XIV, a Europa tomava conhecimento da tese do abade italiano Joaquim de Fiore (1145-1202), que fez divulgar a importância do Espírito Santo para a humanidade. Ele defendia ser a Santíssima Trindade constituída pelo Pai, pelo Filho e pelo

\footnotetext{
${ }^{20}$ Ibidem: p. 139.

${ }^{21}$ Ibidem: p. 139.

22 "Sobre ele [Messias] repousará o espírito de Javé, espírito de sabedoria e inteligência, espírito de conselho e força, espírito de ciência e temor a Javé e ele respirará o temor de Javé." (ISAÍAS, 11, 2. In: Ibidem: p. 764).
} 
Espírito Santo, de forma separada - não comportava três pessoas em uma só. As entidades corresponderiam, na verdade, a três períodos da vida na Terra: o primeiro é o da Lei ou do Pai, momento da criação do universo, relatado no Antigo Testamento, que terminaria em água, com o dilúvio; o segundo período é o do Filho (Jesus) ou da Fé, que nasce do Pai pregando amor e caridade, registrado no Novo Testamento. O Tempo do Filho terminaria em sangue na cruz; por fim, o período do Espírito Santo ou do Júbilo, da alegria que traria o fim do sofrimento e promoveria a caridade, a esperança, a alegria, a fartura e a justiça entre os povos. Começaria a ser escrito o Evangelho Eterno, com o advento da Era do Espírito Santo, que estaria por se iniciar no século XIII. (LEFEBVRE, 1980; BRANDÃO, 1978; MARTINS, 2007). O Tempo do Espírito Santo, segundo Martins (2007: C-11) "seria a antecipação utópica do reino da plenitude do homem na história, o tempo da sua libertação, o tempo do nascimento histórico dos contrários, em que o bem nasceria das ruínas do mal”. Este seria, segundo o autor, o tempo do Novíssimo Testamento, que terminaria em fogo.

Explica Lefebvre (1983: 131):

Assim se periodiza o tempo. O Pai é a Lei em todos os sentidos: Lei de sofrimento e de morte, Lei moral e política, Lei do Chefe e do Senhor, Lei da guerra e da luta para viver ou sobreviver. O Filho traz a fé: confiança no discurso, na escrita e no saber, no futuro e no resultado dos acontecimentos, fé nas capacidades da organização e da razão, fé no conhecimento explicitado durante as discussões. Quanto ao Espírito, ele não traz a alegria: é a alegria. Escapando, sem excluir a violência, à Lei de luta e de guerra, pacificando a vida carnal sem destruí-la, mas integrando-a pelo amor e pela contemplação à vida espiritual, dirigindo para si palavras e discursos, o Espírito indica e abre o caminho da alegria eterna.

Para que o caminho fosse aberto rumo à alegria eterna, seria necessário, conforme Fiore, a presença de um novo "chefe", assim como foi Jesus Cristo. Este novo "chefe" substituiria os bispos da Igreja Católica - o que representava ameaça ao poder clerical - e levaria a paz e a harmonia aos povos, acabando com a pobreza e as doenças que aterrorizavam os europeus (BRANDÃO, 1978: 143). As suas idéias ganharam muitos adeptos, entre eles, os franciscanos, que associaram a figura do novo "chefe" a Francisco de Assis, falecido no início do século XIII. Foram os franciscanos alguns dentre os responsáveis pela divulgação da tese de Fiore nos Açores e nas colônias portuguesas (BRANDÃO, 1978), culminando nas festividades em homenagem ao Espírito Santo, a

A piedade, sétimo dom atribuído ao Espírito Santo, encontra-se na Primeira Epístola de Paulo aos Coríntios, já no Novo Testamento. Porém, Paulo o trata por "caridade", o dom supremo do amor 
exemplo do que já ocorria em Portugal, onde a sua devoção teria se tornado forte devido à graça concedida aos reis Dom Diniz e Dona Isabel ${ }^{23}$. Segundo a lenda, a Rainha havia oferecido o cetro e a coroa reais ao Espírito Santo (talvez por estar influenciada pela tese de Fiore, na perspectiva de dias melhores) diante da crise pela qual Portugal estava passando, tornando-o com este gesto, Imperador de Portugal. A Rainha Dona Isabel retirou-se no Convento de Santa Clara, retornando depois de seu reino ter superado a crise. Em agradecimento ao Espírito Santo, ela promoveu uma festa em sua homenagem, que se repetiria a cada ano (CASCUDO, 2001). Os "vodos" acompanhavam a festividade, sendo um momento para se praticar a caridade, nos moldes dos Othons. Um "imperador", provavelmente alguém do povo, era coroado durante a comemoração de Pentecostes, representando os pobres no poder, mesmo que por curto espaço de tempo.

Conforme Vieira Fazenda, assim se desenrolava a festa do Espírito Santo em Portugal:

[...] no domingo, pela manhã, entrava na egreja do Convento de S. Francisco o que havia de servir de imperador, assistido de dous reis, e seguido de nobreza e povo, com três pagens, que lhes levavam as côroas (uma das quaes era a que deixou para a festa a mesma Sancta Rainha); e sendo estas offerecidas no altar, um religioso, com vestes sacerdotaes, coroava com estas aos três suppostos monarchas que, assim coroados accompanhavam a procissão. Á tarde, saía o imperador da egreja do Espírito Sancto, com muitas festas, trombetas e multidão de gente, com cannas verdes nas mãos e dous pagens adeante com a coroa, e outro com o estoque, e assim entrava na egreja de S. Francisco. O sacristão ahi dava ramilhetes a nobres, que dançavam com duas donzellas honestíssimas que accompanhavam o imperador, na qualidade de damas, a título de se lhes dar parte do dote para casamento. Esta mímica era precedida de nova coroação; depois voltava o imperador á egreja do Espírito Sancto e lá depunha a coroa nas mãos de um sacerdote.

Nos dous domingos seguintes continuava a festa, e no último entrava muito pela meia noite, e por isso se lhe chamavam domingo dos fogaréos, em conseqüência das luzes. As vésperas eram solemníssimas, e depois dellas se fazia uma apparatosa procissão chamada da candeia, de que a mesma Sancta Rainha foi auctora, e saía de S. Francisco, accompanhada de um homem com umas madeixas de cera, de que ficava ardendo uma

(CORÍNTIOS 12; 13. In: Ibidem: p. 1191; 1192).

${ }^{23}$ Conta a lenda que a Rainha Dona Isabel, santificada em 1625 (PIAZZA, 1953) e conhecida como Rainha Santa, era de uma bondade imensa, e chegava a desobedecer o seu marido, o Rei Dom Diniz, para praticar a caridade. Um dia estava a Rainha levando pães em uma cesta, para serem doados aos pobres quando foi abordada e questionada pelo Rei. Como os pães estavam cobertos, ela disse estar levando rosas. Desconfiado, ao descobrir a cesta, Dom Diniz encontrou somente rosas. (MACEDO, 2002 ) 
ponta no altar, e o mais se estendia pela villa até chegar á egreja da Triana. (FAZENDA, 1923: 367, grifo do autor).

Em fins do século XV e início do XVI, Dom Manuel (1469-1521) restringiu a prática dos "vodos" somente às Festas do Divino Espírito Santo (ETZEL, 1995: 30). Talvez, fosse este um acontecimento importante para Portugal, a fim de lembrar a superação da crise no reinado de Dom Diniz, ou então, como afirmou Vieira Fazenda (1923), seria homenagem de Dom Manuel à Rainha Isabel, incentivadora dos festejos ao Espírito Santo, ao reunir "os elementos existentes nos usos e costumes populares" (ETZEL, 1995: 59).

As festividades, com o tempo, foram ganhando cada vez mais contornos místicos, o que abria espaço para atitudes muitas vezes consideradas heréticas em alguns momentos, pela Igreja, pois se associavam à festividade elementos pagãos numa incorporação espontânea, fortalecendo a idéia de fartura e abundância (ETZEL, 1995). Referimo-nos às festas pagãs, que seguiam o ritmo do ciclo da natureza, respeitando o tempo do plantio, da colheita, e do descanso. Portanto, na Europa festejava-se o fim do inverno e a chegada da primavera e do verão, manifestação de gratidão e garantia de boa colheita; eram as festas janeiras e maias ${ }^{24}$.

As maias eram cantigas que a infância festejava na chegada do mês de maio; são recordações festivas em que o povo congratulava-se com os seus protetores, pondo-lhes giestas às portas e cantando-lhes debaixo das janelas. A tradição popular atribui estes costumes de lançarem-se giestas pelas portas à memória do que se praticou com a Virgem Maria marcandose o caminho da fuga para o Egito com flores e ramos para que não se perdesse. (FERREIRA, 1875 apud ETZEl, 1995: 30).

Vemos já aqui um entrelaçamento entre o costume pagão e o fundamento cristão que aos poucos, conforme Ferreira (1875 apud ETZEl, 1995), foi tomando o formato de procissões, sendo que, ainda em 1873 se encontravam muitas reminiscências das festas maias. Mesmo subordinada à religião, a festividade mantinha o caráter de culto aos vegetais.

Conforme Frazer (apud ANDRADE, 1937: 54) na Europa costumava-se buscar no mato, espécies vegetais (árvores ou ramos delas) com o objetivo de trazer os benefícios que o espírito da árvore poderia oferecer. Por isso, ainda segundo Frazer, plantava-se ou conduzia-se em cada casa, nas festividades de maio, uma árvore, a fim de que todos pudessem ser beneficiados.

${ }^{24}$ As janeiras e as maias foram proibidas por Dom João I, de Portugal, em fins do século XIV (FERREIRA 1875 and $\triangle N D R A D F \quad 1037$ ) 
As crianças fantasiadas com giestas saíam pelas casas cantando e pedindo, entre outros alimentos, a castanha. Uma parte do que se arrecadava era distribuída entre a população. Obviamente, havia por toda Europa, as variações locais, podendo ser um grupo de crianças ou somente uma moça coroada de flores (Beja - Portugal), ou ainda um moço que seria o Senhor, Moço ou Mestre Maio (Beira - Portugal) que andava pelas ruas coberto de folhagens. Muitas vezes, esse culto coincidia com as festividades do Divino Espírito Santo (ANDRADE, 1937).

Andrade (1937) nos fala de um Moço Maio russo, um menino escolhido entre as crianças e chamado por elas de Homenzinho da Folhagem. Na Suíça, a proximidade com Pentecostes é nítida, pois o Homenzinho da Folhagem é conhecido por Bobão de Pentecostes. O autor encontrou, como nome mais comum, para o moço de maio na Europa, o de Jorge-Verde. Há a incorporação do espírito da árvore, vegetal, portanto, da própria natureza. Nele estão representados todos os poderes de perpetuar a chuva, o alimento, a fartura para os homens e animais e assim, garantir a subsistência. Chegava-se a colocar diante de Jorge-Verde o gado coroado de folhas e flores, para receber uma espécie de bênção da divindade incorporada.

Mário de Andrade (1937) encontrou na Festa do Divino de Mogi das Cruzes, costumes que remetem a estas festas da Idade Média. O cortejo com carros de bois enfeitados com flores coloridas, carregando folhas de palmitos os quais eram distribuídos em pequenas covas pelas ruas da cidade significava para Andrade, mais do que simples ornamentação do festejo. $\mathrm{O}$ autor entendia ser esta uma reminiscência do culto pagão, na festa cristã de Pentecostes (como veremos mais detalhadamente adiante).

A Festa do Divino Espírito Santo (Pentecostes) associou-se às festas pagãs de reverência à natureza, na tentativa de dominá-las, incorporando à religiosidade elementos que explicam a comensalidade como característica importante. Etzel (1995: 31) entende ser a Festa do Divino Espírito Santo de hoje, uma reminiscência destas festas remotas, pois para o autor "foi a única comemoração anual com ênfase na comilança e alegria desenvolvida num Brasil ainda provinciano e rural".

Agregam-se os fundamentos bíblicos, que aparecem associados a cores (vermelho - fogo, e branco - pomba), o culto aos vegetais, que envolve o plantio e a colheita (lembremos aqui do Pentecostes Judaico), e os "vodos", praticados inicialmente em qualquer momento festivo, para suprir a população mais pobre de alimento. Mário de Andrade (1937) arrisca ainda a comparação do Jorge-Verde com o Imperador do Divino, 
ambos portadores de poderes que garantiriam a subsistência do povo, porém este último, numa versão religiosa.

\section{pdfMachine}

A pdf writer that produces quality PDF files with ease!

Produce quality PDF files in seconds and preserve the integrity of your original documents. Compatible across nearly all Windows platforms, simply open the document you want to convert, click "print", select the 


\section{Heranças de Portugal nas Festas Religiosas Populares}

Muitas festas populares no Brasil tiveram sua origem com a chegada dos portugueses, sendo que algumas delas (religiosas ou não) traziam cantos, danças e instrumentos musicais do mundo ibérico. E neste mundo, sob o domínio da Igreja, a vida era entendida através de fundamentos religiosos, com base na crença do poder de Deus sobre os homens. Assim, como afirma Souza (1986a), para os portugueses, a "descoberta do Brasil" estava associada à vontade divina: Deus os havia escolhido para produzir riquezas explorando a natureza na nova terra, e cuidar das almas indígenas que não conheciam Deus.

Cabia ao colono descobrir riquezas na terra e ainda enriquecer os céus, convertendo almas. Parece mesmo haver um movimento de reciprocidade, uma espécie de contabilidade: os bons cuidados da Providência, propiciando o achado de prata e ouro, deveriam ser pagos com almas; por outro lado, quanto mais almas se enviassem aos céus, melhores seriam as disposições do Criador para com os colonos. (SOUZA, 1986a: 34).

Neste "espírito" religioso de negociação com Deus, a colônia portuguesa foi se desenvolvendo, recriando ou traduzindo para a nova realidade que se instaurava, os usos e costumes lusitanos que viriam a se tornar efetivamente brasileiros com a miscigenação.

Muito contribuiu para a o encontro de culturas, a missão dos jesuítas que, já no século XVI estavam incumbidos de "salvar" almas indígenas do paganismo. Organizaramse em aldeamentos ${ }^{25}$ onde o nativo estaria protegido da escravidão imposta pelos colonos (PETRONE, 1995).

${ }^{25}$ Aroldo de Azevedo (1959) cita três tipos diferentes de aldeamentos: as Aldeias do Colégio e as de El Rei localizavam-se nas vizinhanças das cidades e das vilas, mantendo, portanto constantes relações com estas; já as Aldeias Propriamente Ditas ou Missões, eram mais afastadas do centro comercial das cidades. 1) lalizadas no sertão eram administradas exclusivamente nelos relioinsos pdfMachine

A pdf writer that produces quality PDF files with ease!

Produce quality PDF files in seconds and preserve the integrity of your original documents. Compatible across nearly all Windows platforms, simply open the document you want to convert, click "print", select the

"Broadgun pdfMachine printer" and that's it! Get yours now! 
Uma outra forma de domínio português sobre o nativo baseava-se na relação social aproximativa, designada de cunhadismo, por Darcy Ribeiro (1995). O homem branco se aproximava das aldeias e fazia amizade; era-lhe oferecida uma moça para casamento, o que o tornava pertencente ao grupo, gente de confiança.

A instituição social que possibilitou a formação do povo brasileiro foi o cunhadismo, velho uso indígena de incorporar estranhos à sua comunidade. Consistia em lhes dar uma moça índia como esposa. Assim que ela assumisse, estabelecia, automaticamente, mil laços que o aparentavam com todos os membros do grupo. (RIBEIRO, 1995: 81, grifo do autor).

Foi o que aconteceu com João Ramalho, "fundador" de Santo André da Borda do Campo, logo em meados de 1500, que se infiltrou na aldeia de Tibiriçá, se casando com várias índias e dando vida a muitos mamelucos que estariam, mais tarde, a seu serviço nas bandeiras e entradas. Uma vez inserido no núcleo indígena, o poder estava instaurado, inclusive com relação ao aprisionamento e comércio de outros índios, de outras aldeias, talvez inimigas. Segundo Ribeiro (1995), o cunhadismo significava ainda uma forma eficaz de recrutamento de mão-de-obra para trabalhos pesados, como derrubar árvores e transportá-las para os navios.

Não era somente por meio do cunhadismo que os europeus aprenderam a interagir com os indígenas, pois no processo de povoamento era necessário sobreviver na nova terra aproveitando o que ela e seus habitantes ofereciam. Desta forma, com o intuito de promover o catolicismo, os jesuítas aprenderam o tupi-guarani e desenvolveram, inclusive com base no tupi, uma nova língua, o nheengatu.

missionários. Petrone (1995) explica que durante os séculos XVI e XVII a administração dos aldeamentos estava organizada, por uma parte, sob os cuidados dos jesuítas nas ditas "fazendas dos jesuítas", onde exerciam o poder espiritual e temporal (administrativo). Sobre as Aldeias do Padroado Real prevaleceu o poder temporal das Câmaras.

Por representar empecilho aos projetos bandeirantes, justamente porque "protegiam" os indígenas dos colonos, os jesuítas foram expulsos, em 1640, dos Aldeamentos do Padroado Real, marcando um período de esvaziamento e decadência dos aldeamentos. Os missionários cuidariam somente das almas de suas "fazendas", ou seja, dos aldeamentos cuja administração (não só espiritual, mas também temporal) estava sob seus cuidados. Um século depois, em 1759 ocorreu a interrupção da fixação de aldeamentos com a expulsão completa dos jesuítas, permanecendo, outrossim, outras Ordens como a dos Franciscanos, a de Santo Antonio, a dos Carmelitas, a dos Mercedários e a dos Capuchinhos (AZEVEDO, 1959). Em fins do século XVIII, os aldeamentos entraram em decadência havendo o abandono totalem meados do sécul XIX 
Ensinavam músicas cristãs e orações aos nativos, para que esquecessem seus rituais e adorassem a somente um Deus. A estratégia era o uso da cultura nativa para desvirtuá-la, introduzindo costumes e tradições portugueses (TINHORÃO, 2000).

Com as mesmas artimanhas usadas ao se apropriar de rituais pagãos em Portugal ${ }^{26}$, a Igreja, no Brasil já no século XVII, se ocupou em transformar as procissões de Corpus Christi $^{27}$, então bastante populares entre os portugueses, em festividades profano-religiosas também da população indígena. Tal procissão chegou timidamente no Brasil, sem a grandiosidade da de Portugal, onde podia contar com cerca de duas mil e quinhentas pessoas, assistidas por tantas outras às janelas e ruas enfeitadas, chegando a ter, no século XIV, "caráter de instituição representativa da identidade nacional”, conforme apontam os estudos de Tinhorão (2000: 71).

No Brasil, os momentos festivo-religiosos podiam representar certa liberdade, pois a população subalterna e cativa conseguia se movimentar, fugindo ao controle e à vigilância das autoridades; portanto, nem sempre a participação popular nos eventos religiosos era uma manifestação da fé, mas configurava-se no encontro e na comunicação (SOUZA, 1986b: 21), durante a pausa do trabalho árduo.

O fato de a vida girar em torno da religiosidade não garantia que todos fossem religiosos, o que se notificou, já no século XIX, em uma publicação do Correio Paulistano (23/09/1860):

Entre nós as procissões não são mais que um divertimento como qualquer outro: um batalhão de moleques à guisa de batedores precede a cruz da Irmandade... Segue-se finalmente a guarda dos voluntários, isto é, indivíduos de tôdas as qualidades e feitios, uns contando anedotas [...] outros fumando seu charuto, com o chapéu enterrado até as orelhas. (Correio Paulistano apud BRUNO, 1991: 778).

No século XVIII, principalmente em Minas Gerais com a exploração aurífera as procissões ganharam caráter de ostentação simbólico-espetacular barroca. Conforme Souza (1986b), a festa religiosa em Vila Rica (hoje Ouro Preto, MG) era realizada como um

${ }^{26}$ A Igreja se aproveitava, em um Portugal Medieval, da participação coletiva em que consistiam os rituais pagãos, para introduzir uma teatralização evangélica, com pequenas encenações de episódios bíblicos e da vida de santos. No processo de conversão das manifestações pagãs, começaram a se destacar as procissões, já no século XIV, o que garantiria o poder espiritual da Igreja sobre o povo, que as transformava em manifestações profano-religiosas (TINHORÃO, 2000). 
espetáculo luxuoso, criando a ilusão de sociedade rica e igualitária, neutralizando os conflitos e as verdadeiras diferenças, o que revela o poder persuasivo da Igreja. Porém, apesar da riqueza do ouro, o que se tinha em Vila Rica era a pobreza, pois havia a escassez de alimentos, com a concentração de mão-de-obra (escrava) nas minas. A opulência mascarava a pobreza, e o festejo era, antes, pelo sucesso da exploração aurífera do que pela religiosidade, no caso estudado pela autora, a festa do Santíssimo Sacramento. "No momento de sua maior abundância, é como se o ouro estivesse ao alcance de todos, a todos iluminando com o seu brilho na festa barroca." (SOUZA, 1986b: 21).

As ruas eram enfeitadas numa mistura de cores e aromas provindos das flores dos arcos e dos altares, e as janelas das casas eram adornadas com colchas de seda, etc. (SOUZA, 1986b: 19). Conforme Tinhorão (2000), as festividades barrocas do século XVIII foram apropriadas quase totalmente pela elite, por conta de uma vaidade personalista que se instaurava, o que provocava uma ostentação muito grande nas procissões e desfiles cívicos, que implicava em muito dispêndio de dinheiro. Nem todas as festas teriam aqui, a participação popular, por exemplo, de negros cativos, que mais ocorria nos bastidores, em segundo plano (para fazer volume), no carregamento de algum andor, nos preparativos das passeatas e também no papel de expectadores. Afinal, a quem deveria a elite mostrar a sua autoridade e o seu poder? Além disso, ocorriam também as festas mais de caráter popular, como as da coroação de reis negros, nas irmandades, que eram permitidas pelos senhores de escravos.

Enquanto as festividades religiosas se encontram no entrelaçamento entre o sagrado e o profano, que quase não se distinguem um do outro, somente elas são a oportunidade do exercício do lúdico, de uma prática coletiva criativa, fora do ambiente de trabalho. Conforme Tinhorão (2000), durante o século XIX, ganharam força as diversões públicas de ordem burguesa e somente de caráter profano, como os bailes, os espetáculos, as festas carnavalescas. Com o advento de novas alternativas para o lúdico, a participação da elite nas atividades festivas da esfera religiosa ia cada vez mais sendo enfraquecida.

${ }^{27}$ A comemoração de Corpus Christi, ou seja, do Corpo de Deus apresentado no Sacramento da Eucaristia, foi instituída pelo Papa Urbano IV em 1264, tendo-se notícias de sua realização em clima religioso-festivo em Portugal somente em 1318. (TINHORÃO, 2000: 70). 
Complementa Abreu (1999) que em decorrência da romanização ${ }^{28}$, durante a segunda metade do século XIX, os batuques e as comemorações dos negros foram cerceados, houve a diminuição do caráter ostentatório e pomposo nas procissões, reduzindo algumas festividades a simples reuniões paroquiais, muito mais centradas na religião. Ao papel da Igreja podemos juntar uma nova visão de mundo da burguesia, que começava a ver no catolicismo um atraso para o desenvolvimento da sociedade; as autoridades viam nas festas populares um foco de vagabundagem, estimulado pelas barracas com jogos e apresentações teatrais.

\subsection{Festas do Divino no Brasil}

A Festa do Divino tem sido realizada no Brasil desde o século XVIII, ou pelo menos, é neste século que ela passa a ter maior evidência: Tinhorão (2000) descreve a participação de padres que atuavam nas procissões como personagens em Nossa Senhora de Nazaré de Cachoeira, em Minas Gerais; Etzel (1995) cita as Festas do Divino de Pindamonhangaba (SP) e de Salvador (BA).

Já no início do século XIX, foram encontrados no Arquivo da Cúria Metropolitana de São Paulo, registros de Provisões ${ }^{29}$ de exposição a favor do imperador do Divino, referentes às paróquias de Guarulhos, Jundiaí, Bragança, Nazaré, Santa Isabel, Mogi das Cruzes, Freguesias do Ó e de Santo Amaro ${ }^{30}$. Cabe observar que no Brasil Império a Festa do Divino Espírito Santo, com início quarenta dias após a Páscoa e término no dia de Pentecostes, fazia parte do calendário oficial de datas religiosas a serem comemoradas. SCHWARCZ; MACEDO, 1998: 293).

São muitas as localidades do Brasil onde a Festa do Divino é realizada. Considerando-se somente o estado de São Paulo, são conhecidas as festas realizadas nos

${ }^{28}$ A romanização consistiu na retomada, por parte da Igreja, das determinações do Concílio de Trento (1545-1563), em que os locais de culto deveriam ser sacralizados, o clero deveria ser moralizado, a hierarquia da Igreja deveria ser respeitada e reforçada, diminuindo, portanto, o poder dos leigos que atuavam nas irmandades (ABREU, 1999).

${ }^{29}$ As Provisões eram pedidos de autorização para a realização de alguma festividade religiosa à Arquidiocese de São Paulo.

30 ACMSP - Reoistro de Provisões 1818_1827 
municípios de São Luís do Paraitinga, Cunha, Mogi das Cruzes, Biritiba Mirim, Salesópolis, Guararema, Itatiba, Itu, entre muitos outros onde a Festa do Divino é realizada. Segundo Rodrigues Filho e De Carlo Filho (2004), nos municípios paulistas de Piracicaba, Laranjal Paulista, Tietê e Anhembi, a Festa do Divino é comemorada no rio com uma procissão fluvial e o Encontro das Canoas.

Em outros estados brasileiros, a Festa do Divino realizada em Parati (RJ) foi estudada por Marina de Mello e Souza (1994); a de Pirenópolis (GO) foi muito bem estudada por Carlos Rodrigues Brandão (1978), e hoje ganha destaque por causa das Cavalhadas, uma representação da guerra travada entre cavaleiros cristãos (vestidos de azul) e mouros (vestidos de vermelho), terminando com os cristãos vencedores; em Sabará (MG), conforme Magalhães (2001), a Festa do Divino é realizada pela Sociedade do Divino Espírito Santo, que possui cerca de duzentos e noventa sócios ${ }^{31}$.

Conforme Abreu (1999), a Festa do Divino Espírito Santo era considerada o maior evento popular e de ostentação no Rio de Janeiro, no período de 1830 a 1900. Para Maria Clementina P. Cunha (in: Prefácio de ABREU, 1999: 14), a Festa do Divino, ao compreender o convívio do diferente e do conflito no lúdico, “constituía-se, sobretudo, como momento privilegiado de comunicação, diálogo, negociação cultural nos termos daquela sociedade e daquela cidade".

As irmandades ${ }^{32}$ tiveram importante papel para a manutenção das festas religiosas, cabendo à Irmandade do Espírito Santo a realização da Festa do Divino. Tais festividades eram consideradas o momento máximo das atividades das irmandades, uma vez que serviam para reafirmar a devoção dos seus fiéis, como também eram ocasião para angariar fundos para a prática da caridade ${ }^{33}$. Até 1820 era função da referida Irmandade, no Rio de Janeiro, a distribuição de pães e roscas aos devotos que oferecessem esmolas para a festa, além de pão e carne aos presos na cadeia, pois em Pentecostes comemora-se a fartura, a alegria

31 Para saber mais localidades onde a Festa do Divino é realizada, consultar site: http://www.portaldodivino.hpgplus.com.br.

${ }^{32}$ Conforme Macedo (2002), as irmandades proliferaram no Brasil após a expulsão dos jesuítas, no século XVII, e tiveram origem na Baixa Idade Média, no século XIII. O auge das irmandades deu-se no Brasil no período das minerações, sendo construídas várias igrejas e promovidas festas e procissões em homenagem a seus oragos. Diante da missão catequética, era permitida às irmandades a incorporação de negros cativos em suas organizações, porém, jamais com cargos de diretoria.

${ }^{33}$ Às irmandades cabia, não só durante as festas, a assistência aos enfermos e inválidos, auxílio às famílias em caso de morte, bem como a alfabetização gratuita dos filhos de seus membros, os quais 
proporcionada a todos, quaisquer que sejam as condições sócio-econômicas, mas principalmente, para os mais necessitados: negros, escravos, pobres, presos, enfermos (ABREU, 1999).

A Festa do Divino Espírito Santo mantém, no Brasil, alguns elementos que já estavam, no século XIV, cristalizados em Portugal. Uma das figuras mais importantes é a do Imperador do Divino que atualmente, em alguns locais, foi substituído pelos chamados Festeiros, os responsáveis pela realização da Festa. Conforme a lenda que explica a devoção da Rainha Dona Isabel, já mencionada, o Espírito Santo tornou-se o Imperador de Portugal. Mas o personagem "imperador" poderia ter suas raízes no ato de coroação durante uma missa, de um mendigo, a pedido da Rainha Dona Isabel, em um culto ao Espírito Santo (FIGUEIREDO, 1957 apud MACEDO, 2002). Provavelmente tal ato não foi tolerado por muito tempo em Portugal, pois de mendigo, o Imperador do Divino passou a ser alguém (criança ou adulto) de família abastada que tivesse condições de arcar com a distribuição de alimentos aos pobres (MORAES FILHO, 1979). Percebemos aqui a manutenção dos "vodos" - claro que não da mesma forma como ocorria no século X, pois os costumes se ajustam ao seu tempo.

No Rio de Janeiro do século XIX, o Imperador menino ficava no interior do Império do Divino, abrigo do altar do Espírito Santo, montado a cada Festa, ao lado da igreja. O imperador do Divino não só recebia homenagens e esmolas da população, como também presidia o leilão das prendas (FAZENDA, 1923).

Moraes Filho (1979: 44), registrou o ritual no qual o Imperador do Divino seguia para o Império:

E conjuntamente, no centro de quatro varas pintadas de encarnado [formando um quadrado no qual a corte fica no seu centro], vinha o imperador, um menino de dez a onze anos, vestido de casaca de veludo verde e manto escarlate, calção, meias de seda, sapatos afivelados, com coroa e cetro, tendo ao peito o refulgente emblema do Espírito Santo. Dois mordomos, de casaca, chapéu de pasta, espadim e calção suspendiam-lhe o roçante manto, e todos com a folia tomavam lugar no império, artisticamente adereçado para recebê-los.

contribuíam com uma certa quantia (espécie de anuidade ou mensalidade) para o exercício da caridade (ARREI 1999) 
A música tocava, as danças principiavam, assistindo à função o imperador, repimpado em sua cadeira de espaldar, e diante de uma mesa coberta de uma colcha de damasco, na qual além da coroa e cetro que descansavam, via-se uma grande salva de prata para as esmolas, grandes maços de registros e pombas do Divino para serem distribuídos.

$\mathrm{Na}$ cidade do Rio de Janeiro, se a família do Imperador não tivesse condições de doar à Irmandade do Espírito Santo alguma coisa de valor para a realização da Festa, a própria Irmandade cobria os gastos com o que arrecadava em esmolas (que chegavam a ser pedidas pelos jornais) e com o que vendia nas barracas de doces e salgados durante a própria Festa. Cabia à Irmandade a eleição do festeiro, legitimando o seu poder majestático que se estendia, inclusive, a pagamento de fiança de presos por dívida (ABREU, 1999).

Vale a pena citar Oswald de Andrade (1990: 40) que, na sua infância foi Imperador do Divino, na São Paulo do início do século XX:

Tudo aquilo se realizava por sorteio, naturalmente inspirado pelo Espírito Santo. Liam-se em meio da novena os nomes e os encargos [respectivas funções]. Era um atordoamento de incenso, de campainhas sacras e de badaladas de sino na torre quando saía a indicação do Imperador. Pois uma vez leram o meu nome todo - José Oswald de Souza Andrade - e a voz grossa e tonitruante do vigário da Consolação, que se chamava Cônego Eugênio Dias Leite, berrou: - Imperador do Divino!

Minha mãe nunca se sentiu tão comovida e orgulhosa em sua vida e meu pai, suando na corretagem e na venda dos terrenos, pagou, grato, as despesas da festa. Não havia somente chateações e corvées de horas ajoelhadas em frente ao oratório e na Igreja. Vinham também as saborosas e grandes broas do Divino, os cartuchos de procissão, as honrarias e festividades.

A partir do dia em que aconteceu o sorteio, Oswald de Andrade, e principalmente seus pais, teriam que trabalhar e angariar fundos para a festa que aconteceria no ano seguinte (ANDRADE, 1990). Sua família tinha que arcar com a Festa do Divino Espírito Santo pelo fato de Oswald de Andrade ter sido sorteado durante a distribuição dos encargos.

Conforme Brandão (1978), em Pirenópolis (GO) as pessoas se inscreviam para o sorteio de encargos. A distribuição das funções na Festa era, na crença dos devotos, a manifestação da vontade do próprio Espírito Santo, fato também observado por Andrade (1990) na Festa do Divino em São Paulo. Muitos que se candidatavam não tinham posses, mas viam no sorteio a possibilidade de pagamento de promessas. Assim, uma vez "escolhidos pelo Espírito Santo" para Imperador, os menos aquinhoados poderiam provocar, 
diante dos devotos, a decadência da Festa, ou, no mínimo, ela não aconteceria com tanta ostentação. Se isso ocorresse era entendido como a vontade do Divino, devendo, portanto, a escolha ser respeitada, apesar do risco que, na realidade, representava.

A Folia do Divino compõe o cenário da Festa atuando, porém, antes mesmo do período da Festa. Costume português, a Folia do Divino do Rio de Janeiro do século XIX, descrita por Abreu (1999), constituía-se por um grupo que carregava a bandeira do Divino em peregrinação, e a oferecia às pessoas para beijarem e passarem pelo corpo, com o objetivo de cura de alguma enfermidade; em troca, a Folia recebia uma ajuda em espécie (verduras, frutas, ovos, animais, etc.) ou em dinheiro. Em alguns momentos, a Folia era agraciada com refeição e pousada, oferecidas principalmente pelos moradores da zona rural, devido às longas distâncias entre um sítio e outro. Tudo o que a Folia arrecadava era para ajudar os festeiros, ou seja, a família do Imperador para a realização da Festa do Divino.

O grupo de foliões era acompanhado por músicos barbeiros ${ }^{34}$, geralmente negros (escravos ou livres), contratados pela Irmandade do Espírito Santo provedora da Festa (juntamente com o festeiro), e saíam com a bandeira e uma sacolinha, no intuito de nela guardar as esmolas arrecadadas (ABREU, 1999).

Assim descreve Vieira Fazenda (1923: 372) os Foliões do Divino no Rio de Janeiro do século XIX:

[...] no sabbado da Alleluia saíam das egrejas de Mata-Porcos, Sanct'Anna, Sancta Rita e Lapa do Desterro, bandos de rapazes vestidos de calção de cor, jaqueta ou casaca de chita ou de seda, sapatos rasos debruados de fitas e chapéos desabados com plumas e flores. Um, o mais taludo, levava a bandeira encarnada do Divino representado sob a forma de uma pomba. Atraz, em distancia conveniente, caminhava o imperador, casaca de vélludo encarnado, calções idem, meias de seda branca, cabelleira empoada e de rabicho, espadim ao lado, e grande medalhão pendente do pescoço.

Desses foliões, quatro tocavam pandeiro, dous viola, e um tambor. Ermãos da confraria com sacolas esmolavam entre o povo. Era o séqüito acompanhado por grandes grupos de vadios e desocupados.

${ }^{34}$ Barbeiros de profissão, muitas vezes os músicos também eram sangradores e aplicadores de ventosas. O grupo de músicos barbeiros tinha, na verdade a função de divulgar eventos. Acompanhavam não só a Folia do Divino, anunciando a chegada da Festa do Espírito Santo, mas divulgavam, ao som de seus instrumentos musicais (de sopro e de corda) também outras festas religiosas, promovidas pelas irmandades diversas, além de peças teatrais, totalmente independentes daesfera relioiosa (DERRET 1940. $\triangle$ RREI 1909) 
Tocavam e cantavam os seguintes versos:

Oh Divino Espírito Sancto

Pae dos pobres, amoroso,

Ponde senhor, no meu peito,

Um coração fervoroso.

O Divino Espírito Sancto

É Sancto Consolador,

Consolae a nossa alma,

Quando deste mundo for.

O Divino pede esmola,

Mas não é por carecer,

É só para experimentar

Quem seu devoto quer ser.

Tantas moças na janella

Não fazem sinão olhar;

O Divino pede esmola

Mas ellas não sabem dar.

A bandeira se despede

Com toda a sua folia;

Viva a dona desta casa

E toda sua companhia.

(FAZENDA, 1923: 372-373)

\section{pdfMachine}

A pdf writer that produces quality PDF files with ease!

Produce quality PDF files in seconds and preserve the integrity of your original documents. Compatible across nearly all Windows platforms, simply open the document you want to convert, click "print", select the "Broadgun pdfMachine printer" and that's it! Get yours now! 
Foto 1.

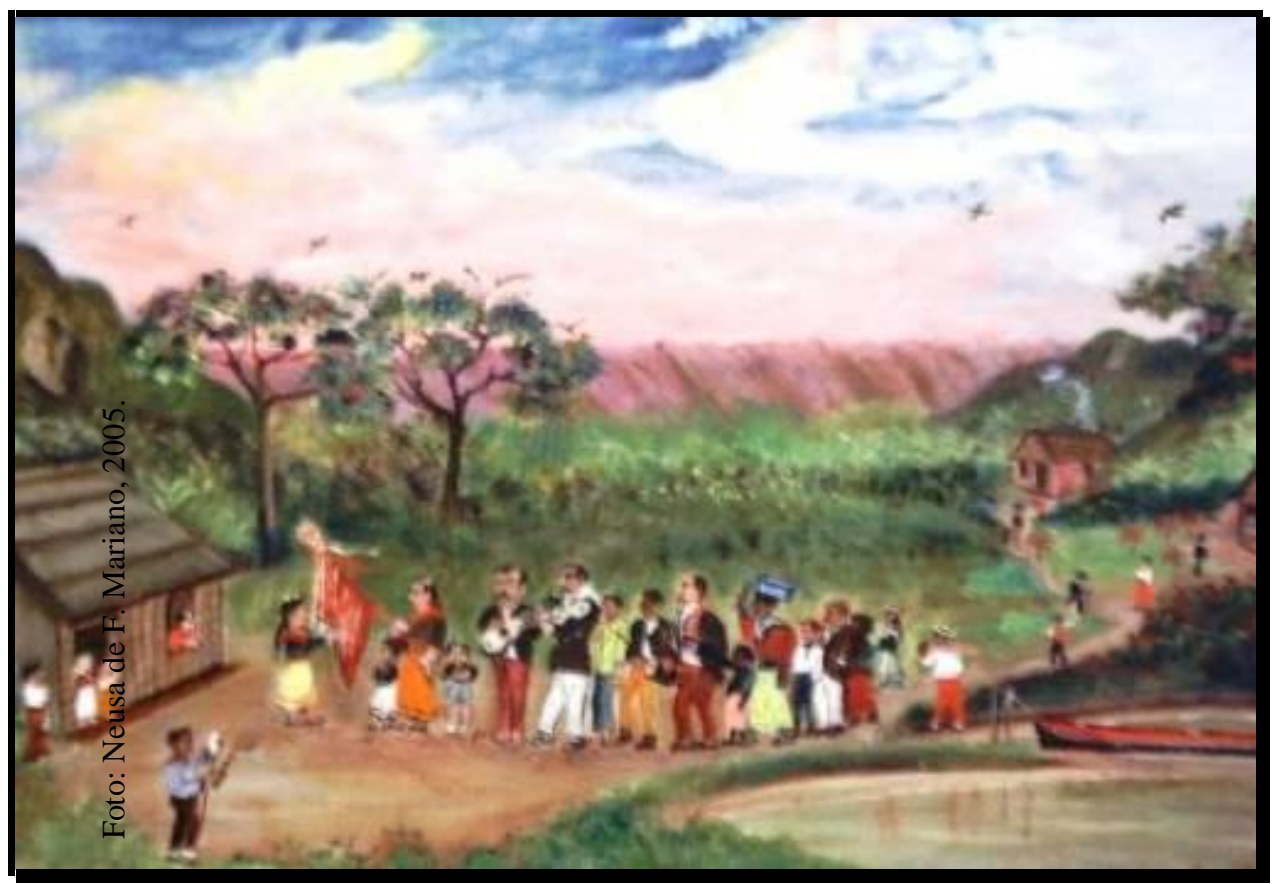

"Bandeira do Divino", de Emigdio de Souza (1868-1949). Óleo sobre tela. Acervo da Pinacoteca do Estado de São Paulo.

Foto 2.

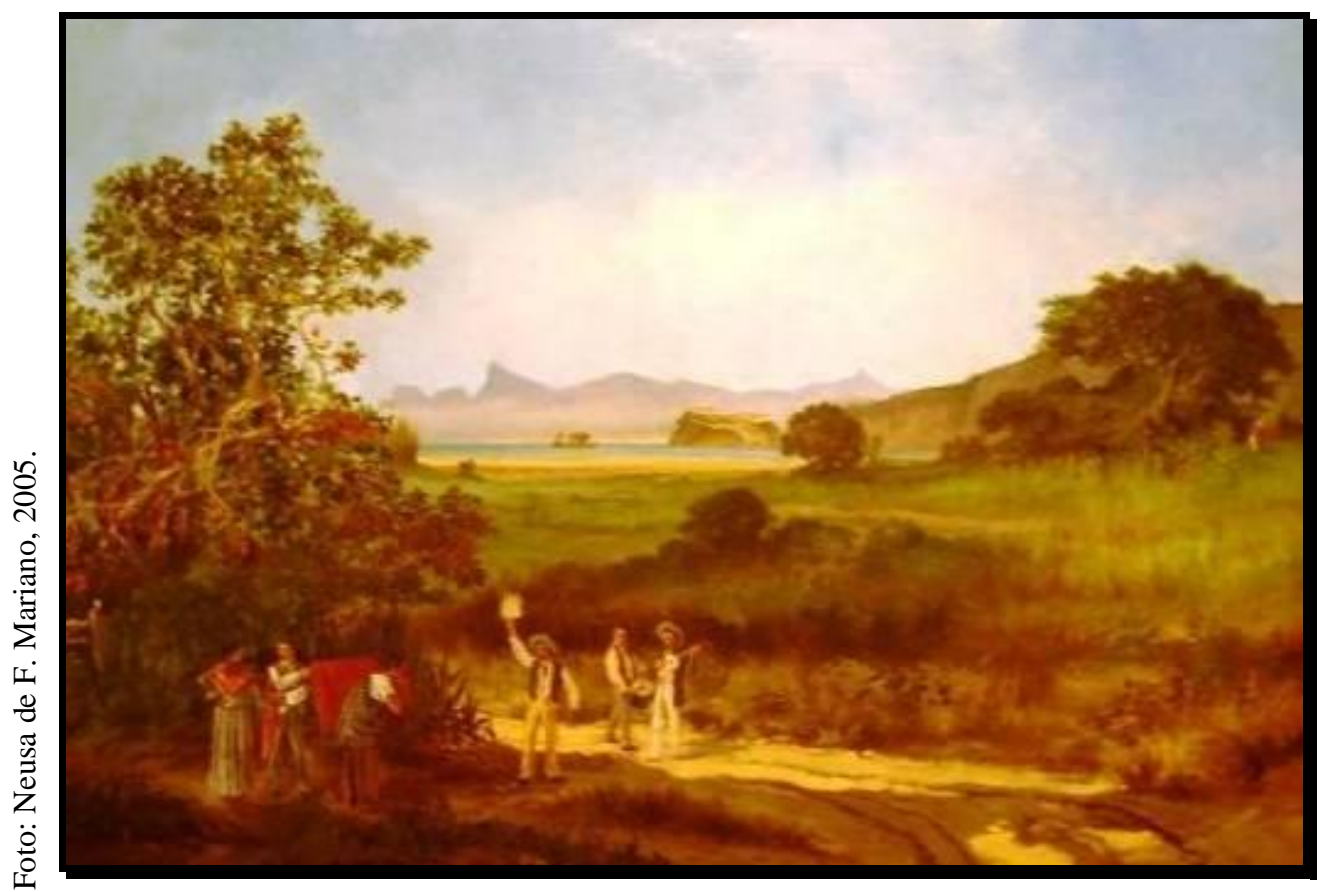

"Bandeira do Divino", de Firmino Monteiro (1855-1888). Óleo sobre tela. Acervo da Pinacoteca do Estado de São Paulo.

\section{pdfMachine}

\section{A pdf writer that produces quality PDF files with ease!}

Produce quality PDF files in seconds and preserve the integrity of your original documents. Compatible across nearly all Windows platforms, simply open the document you want to convert, click "print", select the "Broadgun pdfMachine printer" and that's it! Get yours now! 
Com o tempo, conforme Abreu (1999), a figura dos músicos barbeiros foi se fundindo ao restante do grupo, terminando por serem todos componentes da Folia do Divino, mantendo a estrutura, ou seja, com músicos e bandeireiro (aquele que carrega a bandeira do Divino).

A Folia do Divino, em Cunha, São Luiz do Paraitinga, Pinhalzinho, entre outras localidades no Estado de São Paulo, segundo Martins (1975: 110), realiza um ritual integralmente religioso:

No seu trajeto geral, a Folia desloca-se de um bairro rural para outro e, em cada bairro, uma casa se transforma em pouso da bandeira: é o local em que os foliões se alimentarão e pernoitarão, antes de seguirem para outro bairro.

Continua o autor dizendo que parava a Folia em alguma habitação onde o rito era cumprido com a música, em que se pedia abrigo à bandeira do Divino e um ajutório, depois se agradecia e se formulavam votos de saúde, paz, alegria... A bandeira, que ficava durante todo o ritual nas mãos dos donos da casa, depois de ter passado por todos os seus cômodos, era devolvida aos foliões.

Os leilões eram comuns na Festa do Divino do Rio de Janeiro em fins do século XIX e início do XX, conforme descreve Moraes Filho (1979), em que os arremates, às vezes exagerados, eram de roscas, pães-de-ló, aves como marrecos e galinhas. Apresentações circenses eram realizadas ao lado das barracas da Festa, dentre elas, brincadeiras de palhaços e animais amestrados. No dia de Pentecostes, seguindo a tradição, eram distribuídos alimentos aos pobres:

Na manhã da festa, os bandos mascarados percorriam a cavalo as ruas da vila, e o festeiro mandava distribuir pelos pobres, presentes de carne e de roscas, belos quartos de carneiro e finíssima farinha, em louvor ao Divino. (MORAES FILHO, 1979: 43).

Como não poderia deixar de ser, a Festa do Divino no Brasil tem suas especificidades. Entre elas, cabe destacar a participação de grupos de congadas, que carregavam bandeiras de seus próprios santos devocionais, geralmente santos negros como São Benedito ${ }^{35}$, na verdade, um mouro, e Santa Efigênia ${ }^{36}$. Porém, cabe ressaltar que tais

${ }^{35}$ São Benedito era descendente de escravos africanos e viveu na Sicília no período de 1526 a 1589, sendo canonizado em 1807 (SOUZA, 2002).

${ }^{36}$ Santa Ifigênia foi uma princesa Núbia que se converteu ao cristianismo pelo apóstolo Mateus (SOIZA 2002) 
grupos não se fazem presentes em todas as Festas do Divino, pois há lugares em que suas manifestações não foram mantidas ou, por qualquer motivo, não se integraram à Festa de Pentecostes. O fato é que muitos destes grupos começaram a se incorporar às festas religiosas, a partir de procissões, sob os cuidados das Irmandades (século XVIII e XIX).

Através delas [das Irmandades] tinham a permissão da municipalidade para realizar as congadas, batuques e sambas nos largos das igrejas proibidas por volta de 1860. Mais tarde, normalmente essas autênticas batucadas passaram a ocorrer após as procissões religiosas, quando os negros se reuniam em frente ou nos terrenos atrás das igrejas, onde podiam livremente dançar, cantar e tocar seus instrumentos. (MORAES, 1995: 7576).

A rápida assimilação dos cativos negros ao catolicismo no Brasil já vinha de um processo catequético iniciado na África pelos portugueses, especialmente no Congo e em Angola $^{37}$.

Conforme Câmara Cascudo, as congadas são um tipo de

Folguedo de formação afro-brasileira, em que se destacam as tradições históricas, os usos e costumes tribais de Angola e do Congo, com influências ibéricas no que diz respeito à religiosidade. Lembra a coroação do Rei Congo e da Rainha Ginga de Angola, com a presença da corte e seus vassalos. [...] As congadas com representação teatral focalizam sempre a luta entre mouros e cristãos, terminando com a vitória dos cristãos e a conversão dos mouros, que são batizados no final. (CASCUDO, 2001: 149).

A inclusão da luta entre cristãos e mouros nas congadas ilustra bem a influência dos portugueses nas festividades dos negros, sendo associadas entre outras festas, também

${ }^{37}$ Segundo Marina de Mello e Souza (2002) houve, a partir de 1483, a adoção de símbolos portugueses pelo reino do Congo na África, onde já havia uma sociedade organizada com um rei centralizador do poder. Na aproximação dos dois reinos, os congoleses começaram a ser batizados na fé cristã, a começar pelos seus governantes e pessoas que teriam maior poder na hierarquia social. Por entenderem que os lusitanos eram enviados de Nzambi Mpungu, o deus que reinava sobre tudo, os africanos logo aceitavam os novos ritos, abraçando de bom grado o cristianismo, mas sem saber. Acontece que a simbologia era parecida entre os dois reinos, mas seus significados eram completamente diferentes. A cruz, por exemplo, para os congoleses

[...] era um símbolo de especial importância nas relações entre o mundo natural e o sobrenatural e a representação básica da cosmologia bacongo, organizada a partir da divisão entre o mundo dos vivos e o dos mortos, um sendo reflexo do outro e estando ambos separados pela água. Portanto, é importante ressaltar que, ao adotarem a cruz católica, os congoleses estavam expressando suas crenças tradicionais ao mesmo tempo que levavam os portugueses a achar que abraçavam integralmente a nova fé. (SOUZA, 2002: 60). 
às do Divino Espírito Santo (SOUZA, 2002: 299). Mas as congadas tinham o seu momento mais festivo na coroação do Rei Congo ${ }^{38}$, que consistia em uma celebração anual, feita no interior da igreja (provavelmente de Nossa Senhora do Rosário dos Homens Pretos ${ }^{39}$ ), logo após a missa e com na bênção do padre, por vezes, contra a própria vontade. Segundo Souza (2002: 283) era recorrente nos registros de naturalistas estrangeiros, no século XIX, a encenação de conversão de um representante estrangeiro ao cristianismo reinante no Congo. Este era o enredo do auto, que provavelmente teve suas variantes, conforme o lugar e as circunstâncias, porém terminando sempre com a conversão do estrangeiro ao cristianismo.

Ao permitir a manifestação de tais grupos, a Igreja, estrategicamente, abria espaço para a vida religiosa do negro, com o intuito de não perder o seu poder sobre eles. Outros santos foram impostos, para que a população escravizada os adorasse e, acima de tudo, com eles se identificasse, a serviço da cristianização dos negros (SOUZA, 2002: 185; 189).

Segundo Souza (2002), consolidava-se através das festividades de coroações de reis congos, uma nova forma de expressão cultural. Mas com o tempo, foi ocorrendo uma simplificação do ritual de coroação, desaparecendo muitos dos seus elementos, como as dramatizações em alguns lugares. Reduziram-se, cada vez mais o número de grupos que passaram a ser considerados folclóricos pela elite, tanto por causa de seu aspecto "atrasado" quanto por serem praticadas pelos estratos sociais oprimidos. A própria Festa do Divino Espírito Santo foi se modificando ao longo do tempo, no Brasil e em Portugal. Há que se observar que ela comporta diferenças conforme a localidade e os referenciais de seus agentes. A Festa do Divino tornou-se uma festa que permitiu a inserção de elementos culturais diversos, como os grupos de congada, justamente porque ela se tornou popular, porém sem perder suas raízes na realeza de Portugal (no reinado de Dona Isabel).

No mal entendido, os portugueses acreditavam ter convertido os congoleses ao catolicismo, e mantinham uma relação mercantil estável, baseada no tráfico de escravos para o Brasil.

${ }^{38}$ Conforme Tinhorão (2000), as festas de coroação do Rei Congo têm como datas mais antigas no Brasil, de 1674 a 1675, no Recife (PE), sob a responsabilidade da Irmandade de Nossa Senhora do Rosário.

${ }^{39}$ Tinhorão (2000) mostra que já no século XVI, os escravos africanos em Lisboa conquistaram um espaço paralelo à Confraria de Nossa Senhora do Rosário - de homens brancos. Na impossibilidade de se integrarem à Confraria, instituíram a Confraria de Nossa Senhora do Rosário dos Homens Pretos, a qual chegaria ao Brasil no período escravista, trazendo as festas de coroação do Rei do ronon pdfMachine A pdf writer that produces quality PDF files with ease!

Produce quality PDF files in seconds and preserve the integrity of your original documents. Compatible across nearly all Windows platforms, simply open the document you want to convert, click "print", select the "Broadgun pdfMachine printer" and that's it! Get yours now! 


\section{Dos Primórdios da Festa do Divino de Mogi das Cruzes À SUA ESPETACULARIZAÇÃo}

Os jesuítas, no período do Brasil Colônia, organizaram aldeamentos indígenas em várias localidades, sendo que algumas delas originaram cidades da atual Região Metropolitana de São Paulo. Na região da então Villa de Mogy, havia os aldeamentos de Itaquaquecetuba $^{40}$ que era administrado temporal e espiritualmente pelos jesuítas, e o de Escada $^{41}$ sob administração temporal da Câmara de Mogi das Cruzes, ambos do século XVII. Próximo a Mogi das Cruzes, em fins do século XVI, os jesuítas administravam apenas espiritualmente o aldeamento de São Miguel, sob o gerenciamento temporal da Câmara de São Paulo. (PETRONE, 1995: 162; 165).

Em Mogi das Cruzes, capelas iam sendo erigidas independentemente da missão dos jesuítas, talvez por iniciativa dos proprietários de grandes lotes de terra. Duas delas podem ser apreciadas até hoje e são a Capela de Santo Alberto, na Serra de Itapeti ${ }^{42}$ que foi erguida no século XVII, e a Capela de Santo Ângelo construída em 1738, no atual distrito de Jundiapeba.

As irmandades e confrarias começaram a ocupar espaço no interior das igrejas que se erguiam nos séculos XVIII e XIX na então Vila de Mogi das Cruzes. Assim, teremos,

${ }^{40}$ Itaquaquecetuba foi emancipado de Mogi das Cruzes em 1953.

${ }^{41}$ A Freguesia de Escada pertence atualmente ao município de Guararema, emancipado de Mogi das Cruzes em 1898. A igreja de Nossa Senhora da Escada erguida em 1652, é tombada pelo Instituto do Patrimônio Histórico e Artístico Nacional (IPHAN) e está sendo restaurada pela Petrobras e Sabesp, através da Lei Rouanet. Para saber mais, consultar: http://www.guararema.sp.gov.br. 
entre outras, a Confraria do Santíssimo Sacramento, as Irmandades de Nossa Senhora das Dores, de São Benedito, de Nossa Senhora do Rosário dos Homens Pretos, de Santana ${ }^{43}$, etc... As Irmandades, na qualidade de organizações religiosas, envolviam os moradores em torno de suas atividades. No entanto, só seria membro da Irmandade quem, pelo seu ingresso, efetuasse o pagamento de uma taxa (inclusive os escravos), conforme consta no Livro Entrada de Irmãos da Irmandade Nossa Senhora do Rosário dos Homens Pretos (1722-1836), do Arquivo da Cúria Metropolitana de São Paulo.

A organização das Irmandades veio a facilitar a expressão cultural dos escravos, que praticavam as danças de congada e moçambique durante as festas religiosas do final do século XIX e início do XX, registradas por Grinberg (1983).

Apesar de haver variadas notícias em revistas, jornais, panfletos, sobre a antiguidade de mais de trezentos anos, da Festa do Divino de Mogi das Cruzes, nenhum documento que o prove foi encontrado ${ }^{44}$ durante a pesquisa. $\mathrm{O}$ documento mais antigo, consultado nesta pesquisa, com o registro da Festa de Mogi, refere-se a uma Provisão encaminhada pela Paróquia de Santana de Mogi das Cruzes à Arquidiocese de São Paulo, para a exposição do Imperador do Espírito Santo, com data de $1822^{45}$. Cabe observar que as primeiras Provisões encontradas, relativas à Festa do Divino Espírito Santo, são de procissão e exposição "para Mogy do Imperador do Espírito Santo", ou "para a festividade do Imperador" ${ }^{\text {"46 }}$, fazendo referências também à Imperatriz, como o documento de 1832:

$$
\begin{aligned}
& \text { Prov }^{\mathrm{am}} \text {. de } \operatorname{Expos}^{\mathrm{am}} \text {. e Procissão para festivid }{ }^{\mathrm{e}} \text {. do Imperador de Mogy. } \\
& \text { Prov }^{\mathrm{am}} \text {. de Expos }{ }^{\mathrm{am}} \text {. e Procissão para festivid }{ }^{\mathrm{e}} \text {. da Imperatris de Mogy }{ }^{47} \text {. }
\end{aligned}
$$

${ }^{42}$ Restaurada em 1996, através de uma parceria entre Museu Paulista - USP, Universidade Braz Cubas - UBC e Universidade de Mogi das Cruzes - UMC.

${ }^{43}$ ACMSP - Pastas Avulsas, Mogi das Cruzes.

${ }^{44}$ Grinberg (1981: 124-125) publicou Ata da Câmara de 04/05/1613 na qual há uma referência ao Espírito Santo como data comemorativa; aliás, no período colonial, como tempo era marcado pelo calendário litúrgico, tal documento torna-se insuficiente para se afirmar a existência da Festa do Divino em Mogi desde o século XVII. Contudo, não foi possível ter acesso ao documento original, apesar da pesquisa no Arquivo Municipal e na Câmara de Mogi das Cruzes. Há também a possibilidade de haver registros da Festa do Divino na Cúria de Mogi das Cruzes, o que não pôde ser verificado devido a reformas do prédio no período de desenvolvimento da pesquisa.

${ }^{45}$ ACMSP - Registro de Provisões 1818-1827.

${ }^{46}$ ACMSP - Registro de Provisões 1818-1827.

${ }^{47}$ Leia-se: "Provisão de Exposição e Procissão para festividade do Imperador (Imperatriz) de Moov" ACMSP _ Reoistro de Provisões 1828_1835 (n 153-verso) 
Na década de 1840, as designações de "imperador" e "imperatriz" desaparecem das Provisões:

Prov $^{\mathrm{am}}$. de Procissão e Expos ${ }^{\mathrm{am}}$. para a Villa de Mogy das Cruzes a favor da festivid ${ }^{\mathrm{e}}$. do Divino Espírito Santo ${ }^{48}$.

E somente na década seguinte, surge a denominação de "Festeiros" para os representantes oficiais da Festa. As Provisões começam a ser mais detalhadas, aparecendo a data e a duração da Festa, em alguns momentos ${ }^{49}$.

Provisão de Exposição e procissão $\mathrm{p}^{\mathrm{a}}$. a Parochia de Mogy das Cruzes a favor do Festeiro do Divino Esp ${ }^{\text {to }}$. Santo e tão bem septenário [festa com duração de sete dias] a favor do Festeiro.

Dita de Exposição e Procissão pa . a Parochia de Mogy das Cruzes a favor da Festeira do Divino Esp $^{\text {to }}$. $S^{\text {to50. }}$.

Será que com a figura do Festeiro, a representação do Imperador teria desaparecido das festividades? Nenhum registro referente a Mogi das Cruzes responde nossa questão. Porém, em São Paulo, há uma pista de que o Imperador do Divino existia, havendo a possibilidade de ser o próprio Festeiro:

Provisão de Exposição do S. S. Sacram ${ }^{\text {to }}$. pa a Igreja de N. S. do Rosário dos Homens Pretos desta $\mathrm{ci}^{\mathrm{de}}$. a favor do Imperador digo Festeiro do Divino Espírito Santo ${ }^{51}$.

Já em 1877, a autorização para que a Festa do Divino em Mogi das Cruzes se realizasse, impunha a condição de haver "[...] as luzes necessárias e que as ruas por onde tiver de passar a procissão estejão limpas e asseiadas"

No final do século XIX, as solicitações eram preenchidas em formulários previamente impressos, a exemplo do de 1888:

O Dr. Francisco de Paula Rodrigues, Professor da Faculdade de Direito, Arcediago da Cathedral, Provisor e Vigário Geral do Bispado, Juiz de Genere e Casamentos, por sua Exc. Revdma, etc., etc.

Aos que esta Provisão virem, saúde e paz em o Senhor.

${ }^{48}$ ACMSP - Registro de Provisões 1844-1849, p. 138 - verso.

${ }^{49}$ Idem, 1861-1863.

${ }^{50}$ Idem, 1867-1870, p. 6 - verso.

${ }^{51}$ Ibidem, p. 197.

52 ACMSP _ Pasta A wlsa n ${ }^{\circ}$ IX Mooi das Cruzes 
Faço saber que, attendendo ao que me representou o Festeiro do Divino Espírito Santo da Parochia de Mogy das Cruzes; Hei por bem, pela presente, conceder licença para que no dia da festa que o peticionário deseja fazer celebrar nessa parochia, possa o Revd. Parocho respectivo expôr o Santíssimo Sacramento, por ocasião da missa solemne; e bem assim fazer sahir em Procissão pelas ruas de costume, estando estas limpas e asseadas; comtanto que sejam observadas todas as disposições lithurgicas e determinações diocesanas relativas a taes solemnidades, o que tenho por muito recommendado ao mesmo Revd. Parocho, a quem será esta apresentada. Dada e passada na Câmara Episcopal de S. Paulo, sob o Sello das Armas de S. Exc. Revdma. e o meu signal, aos nove de Maio de 1888. $\mathrm{Eu}$, Carlos Augusto Gonsalves Benjamin, Official da Câmara Episcopal a subscrevi.

[assina] Cônego Antonio Barroso

Registrada á fl. do livro 46

S. Paulo, nove de Maio de 1888

[assina] Carlos Benjamin

Provisão de Exposição e Procissão do Santíssimo Sacramento para a Parochia de Mogy das Cruzes, a favor do Festeiro do Divino Espírito Santo.

Para V. Exc. Revdma. vêr e assignar., ${ }^{, 53}$

$\mathrm{Ana}^{54}$ (49 anos) busca na memória, os relatos de seu pai sobre seu avô, e calcula que por volta da segunda metade do século XIX, ele já participava das homenagens ao Espírito Santo esmolando para a Festa de casa em casa, de sítio em sítio, cerca de três a quatro meses antes do dia de Pentecostes. Como Bandeireiro do Divino, seu avô chegava às residências portando a bandeira vermelha com uma pomba branca ao centro, e rezava junto com as famílias. Sua atuação diferia da da Folia do Divino descrita por Abreu (1999), uma vez que, segundo o relato de Ana, o Bandeireiro peregrinava sozinho e instrumentistas musicais e cantos estavam ausentes.

As pessoas que haviam se comprometido com o Bandeireiro a doar alimentos e animais (legumes, frutas, verduras, galináceos e gado) para a Festa, chegavam à cidade na véspera de Pentecostes. Era essa população recepcionada com uma espécie de carne ensopada, rica em gordura e servida quente, com farinha de mandioca no fundo do prato; era o "Afogado", considerado prato típico e sagrado da Festa do Divino de Mogi das Cruzes até hoje.

${ }^{53}$ ACMSP - Pasta Avulsa n ${ }^{\circ}$ V, Mogi das Cruzes. 
Aproveitando a Festa na cidade, a população oriunda das Serras de Itapeti e do Mar, que vivia com base na produção de subsistência, comercializava ou trocava o excedente; era uma maneira de se conseguir, na cidade, os produtos raros no meio rural, como querosene, tecido, sal... Conforme Ana, as pessoas da roça chegavam em carros de bois, meio de transporte comum em meados do século XIX, forrados com as folhas do palmito sobre as quais era colocada a produção excedente.

Assim, os palmitos "entravam” na cidade, o que significava não só a chegada deste produto e a importância centrada nele, mas a chegada de uma população devota do Espírito Santo, que trazia o produto da roça que representava a fartura, condizente com o fundamento da Festa: colheita, abundância, culto ao vegetal. A Festa proporcionava o estabelecimento de relações de âmbito econômico, uma forma de escoar no mercado local o excedente, e uma forma de alimentar o corpo e a alma, visto o aspecto religioso do festejo.

Dona Maria do Carmo (70 anos), em entrevista, salienta que a população do meio rural chegava aos poucos na cidade pelos seus vários acessos, em horários diferentes, e de modo disperso, portanto. No início do século XX, a população rural que vinha para a Festa espontaneamente começou a se organizar em forma de cortejo, que veio a se constituir na Entrada dos Palmitos, um dos momentos mais significativos, hoje, da Festa do Divino.

A economia de subsistência foi rareando com o passar do tempo. A organização social foi se assentando sobre a divisão do trabalho, fazendo surgir mais claramente as diferenças entre as classes sociais (SINGER, 1977). Em 1875, a ferrovia que ligaria São Paulo ao Rio de Janeiro, (Estrada de Ferro do Norte que, depois da queda do Império, em 1890, foi incorporada pela Estrada de Ferro Central do Brasil ${ }^{55}$ ) chegou em Mogi das Cruzes, trazendo com ela possibilidades várias de investimentos na indústria, no comércio e nos serviços. O modo de vida foi, pouco a pouco, rompendo com sua base na economia de subsistência e o dinheiro tornando-se cada vez mais mediador da vida.

No início do século XX, Mogi das Cruzes contava com cerca de cento e quinze estabelecimentos comerciais e de serviços como alfaiataria, hotel, sapataria, comércio de secos e molhados; as fábricas, ainda pequenas, eram treze, sendo nove de produção de vinho, duas de cerveja e duas olarias. Com o objetivo de incrementar o setor industrial o

\footnotetext{
${ }^{54}$ Moradora de Mogi das Cruzes, em entrevista.
} 
poder municipal, em 1909, ofereceu a empresários incentivos para instalarem fábricas em Mogi das Cruzes (doação de terreno e isenção de impostos). (GRINBERG, 1961: 111).

Esta rápida menção às mudanças que ocorriam na estrutura econômica e social de Mogi das Cruzes, seguindo as tendências em curso em São Paulo, conforme apontadas por Singer (1977), têm o intuito de mostrar que, junto com elas, houve mudanças também no modo de festejar o Espírito Santo. Um exemplo é a chegada espontânea da população rural para a Festa, como descrito anteriormente, que passou a ter o formato de desfile, alusivo a este passado. A distribuição do "Afogado" ganhou caráter de ritual muito mais ligado ao sagrado e místico, do que à ordem prática que lhe deu origem, qual seja, alimentar o povo que chegava cansado depois da viagem para a Festa do Divino.

A Festa começou, além disso, a ser notícia, conforme registrou o jornal $\mathrm{O}$ Ypiranga, de 02/07/1899:

Terminaram hoje as cerimônias religiosas em honra ao Divino Espírito Santo, que tiveram início no Domingo passado. O digno festeiro Tenente Manoel Antonio de Lima, tem sido acima de todo elogio, não só nos esforços, para o maior brilhantismo das festas como pela gentileza com que recebe os fiéis que vão á sua casa prestar homenagem ao império do Divino.

A notícia, que data de julho, nos leva a acreditar que a Festa do Espírito Santo não obedecia rigorosamente ao calendário religioso segundo o qual Pentecostes refere-se ao intervalo de cinqüenta dias após a Páscoa. Podia ocorrer, por qualquer motivo, a sua realização em data fora daquela estipulada pela Igreja ${ }^{56}$.

Depreende-se desse registro que o Império do Divino era montado na casa dos Festeiros, bem como a duração do tempo festivo era de oito dias, tendo se iniciado no domingo anterior ao de Pentecostes, ou seja, em 26 de junho daquele ano.

Grinberg (1983) faz um relato da Festa do Divino por volta de $1900^{57}$ em Mogi das Cruzes. Já naquele ano aconteciam as Alvoradas, que são procissões realizadas a partir de

55 Desde 1994, a Companhia Metropolitana de Trens Urbanos administra a linha que parte da Estação Luz em São Paulo e segue até a Estação Estudantes, em Mogi das Cruzes (com transbordo em Guaianazes, em São Paulo).

${ }^{56}$ Em 1917, o Festeiro, que era professor, solicitou à Arquidiocese de São Paulo, através de uma carta, o adiamento da data da Festa do Divino, do mês de maio para o de julho. Tendo a Festa como prioridade, o Festeiro se ausentaria no trabalho, perdendo assim, os benefícios de assiduidade. Naquele ano, conforme propôs o professor, o Divino Espírito Santo foi festejado durante as férias escolares de julho. (ACMSP - Pasta Avulsa ${ }^{\circ}$ V, Mogi das Cruzes). 
5:00h da manhã, pelas ruas próximas à atual Catedral de Santana (Mapa 3) ${ }^{58}$, durante oito dias. Geralmente participavam das Alvoradas somente pessoas que haviam feito promessa ao Espírito Santo, que enfrentavam as baixas temperaturas nas madrugadas no período da Festa como sacrifício, sofrimento que pagaria a graça alcançada. Depois da procissão, todos tomavam café com biscoito, distribuído na igreja. À tarde havia a apresentação dos grupos de Congada e Moçambique, bem como aconteciam brincadeiras (gincanas), e à noite, sempre tinha um leilão e apresentação das bandas da cidade. No sábado, véspera de Pentecostes acontecia a Entrada dos Palmitos, com carros de bois enfeitados com papel crepom colorido.

As esguias palmeiras, cortadas rente ao chão na zona rural, vinham se arrastando pelas estradas de terra e eram, afinal, plantadas nas covas já preparadas nas ruas José Bonifácio e Direita (hoje Paulo Frontin), cujas fachadas das casas ostentavam lanternas de cores variadas, muitas delas, iluminadas a vela. (GRINBERG, 1983: 56).

No domingo, dia de Pentecostes, todos iam para a Praça da igreja Matriz (hoje, Catedral de Santana) onde eram promovidas brincadeiras para as crianças; à noite, a grande procissão do Divino Espírito Santo era acompanhada por todos os devotos e, ao final, às 22:00h, realizava-se a queima de fogos e a finalização da Festa.

Mário de Andrade (1937) observa que a distribuição de palmeiras e palmitos pela cidade durante a Festa do Divino Espírito Santo em Mogi das Cruzes não se deve a simples ornamentação, mas sim, que teria um sentido mais profundo, sendo reminiscência do culto ao vegetal de festas pagãs realizadas na Europa Medieval

A ida ao mato, a escolha da palmeirinha, o corte da árvore ou de seus ramos, o transporte festivo do vegetal ao aglomerado urbano, o seu plantio na praça ou diante das casas, ou prendê-lo de qualquer forma à fachada das casas, os bois de transporte, todo esse ritual, tudo isso que é da própria essência do culto da Maia, se acha repetido na Entrada dos Palmitos.

57 O autor tem como fonte um depoimento que colheu em 1940, porém, reconhece com desapontamento, que não registrou o nome de seu depoente.

${ }^{58}$ O Mapa 3, representando o centro de Mogi em 1901, permite ao leitor identificar o espaço de realização da Festa no passado. 


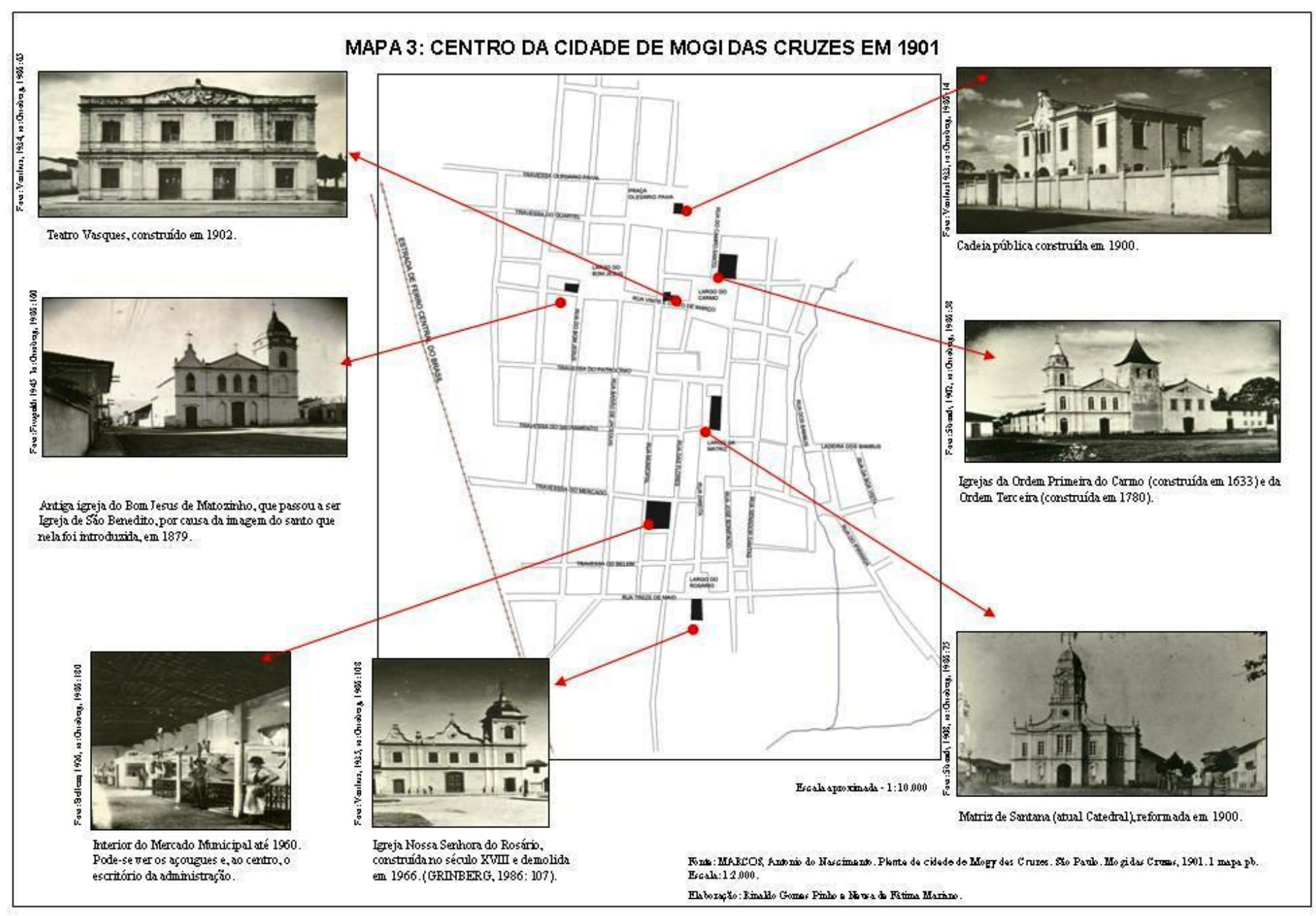

\section{pdfMachine}

A pdf writer that produces quality PDF files with ease!

Produce quality PDF files in seconds and preserve the integrity of your original documents. Compatible across

nearly all Windows platforms, simply open the document you want to convert, click "print", select the

"Broadgun pdfMachine printer" and that's it! Get yours now! 
As únicas referências encontradas sobre a Festa do Divino Espírito Santo em Mogi das Cruzes das décadas de 1910 e 1920 estão nas Provisões ${ }^{59}$ para realização de procissão por ocasião da Festa, conservadas pelo Arquivo da Cúria Metropolitana de São Paulo. As cartas não descrevem a Festa, mas uma delas, datada de 1917 revela que a escolha do festeiro se dava por sorteio, representando a vontade divina:

Sendo sorteado, com a graça de Deus, para realizar no corrente anno, as festas do Divino Espírito-Santo nesta parochia de Sant'Anna de Mogy das Cruzes, a 27 de maio pf., venho expôr ao DD. Arcebispo, os motivos pelos quaes torna-se difícil realizal-as nessa época $[\ldots]^{60}$.

O Liberal, jornal de Mogi das Cruzes fundado em Novembro de 1930, traz, nos anos de 1931 e 1932, matérias sobre a Festa do Divino, inclusive a programação. Vale a pena reproduzir a matéria publicada durante a Festa de 1931:

Tiveram início quinta-feira, á noite, as tradicionaes 'folias' dedicadas ao Divino Espírito Santo. A grande affluencia de fiéis ás mesmas muito concorreu para o seu brilhantismo, reproduzida nas noites de sexta-feira e de hontem. Como fôra annunciada, pela estrada da Capella do Ribeirão, hontem, às 9 horas mais ou menos, deu-se a solene entrada dos palmitos na cidade. Ás 15 horas foram distribuídos innumeros presentes aos presos na cadeia local e às 16,30 horas bombons a 2000 crianças no interior da Egreja Matriz, usando a palavra o Revmo. Pe. Dr. Cícero de Revoredo. Houve o levantamento do mastro às 17,30 horas sob os auspícios do capitão Sr. Antonio Torquato. À noite, após a resa e 'folia', continuação da kermesse iniciada na sexta-feira. Todas as solemnidades foram abrilhantadas pela Corporação Musical Guarany. Também houve distribuição de esmolas aos pobres da cidade.

Hoje, às 8 horas haverá missa parochial, com communhão geral. Às 9 horas, "moçambique" no Largo da Matriz. Às 10 horas, missa cantada, com sermão pelo Revmo. Cônego Dr. F. Bastos. Durante o dia haverá diversos divertimentos, como sejam pau de sebo, ponte falsa, porcos ensebados, corridas em sacos, quebra-potes, etc.

À tarde sahirá solemne procissão do Divino, que percorrerá as ruas da cidade, dando-se ao recolhimento sermão e exposição do SS. Sacramento. Depois será continuada a kermesse, fazendo a Corporação Musical

${ }^{59}$ ACMSP - Pastas Avulsas n ${ }^{\text {os }}$ V, VI, VII, VIII e IX, Mogi das Cruzes.

60 ACMSP - Pasta Avelsa n ${ }^{\circ} \mathrm{V}$ Mogidas Cruzes 
Guarany, no coreto do Largo, uma seleccionada retreta, em que serão tocadas innumeras peças musicaes de grande realce. E para finalisar, á meia noite, vistosos fogos de artifícios, habilmente fabricados pelo pyrotechnico Sr. Benedicto Luz serão queimados no Largo da Matriz.

[...] Tudo se fez na melhor ordem e boa harmonia, tendo-se em conta a responsabilidade de uma festa que representa grandes compromissos financeiros e moraes. (O LIBERAL, 24/05/1931).

Continua a matéria sobre a Festa do Divino no referido jornal, noticiando o sorteio de Caetano Griecco como Festeiro e Fellipe Abib como Capitão do Mastro ${ }^{61}$ para o ano de 1932:

A população catholica mogyana recebeu com sympathia a notícia do sorteio dos novos festeiros, o que é bastante auspicioso, porquanto sendo a festa custeada com seu dinheiro, é de crer-se que os seus promotores encontrem boa acolhida por parte de todos os mogyanos que, afinal, sempre foram generosos para a effetivação desse acontecimento religioso que todos os annos constitue uma das mais importantes commemorações da Egreja Catholica desta cidade. (O LIBERAL, 31/05/1931).

Um ano depois, o mesmo jornal publicou novamente a programação da Festa, matéria parecida com a de 1931. Ao fim das comemorações, o jornal, mais uma vez, anunciou os novos festeiros, agora para 1933, com a seguinte observação sobre os sorteados, Sr. Francisco Affonso de Mello e esposa: "Pessoas bastante relacionadas em nosso meio social." (O LIBERAL, 22/05/1932).

Assim, o Festeiro não arcava sozinho com os gastos do festejo. Na década de 1930, circulava um "Livro de Ouro", no qual as pessoas assinavam se comprometendo a auxiliar os festejos do Divino. Por isso, fazia-se importante o Festeiro ser bem relacionado socialmente, ou seja, ter influências junto a uma elite que poderia contribuir com somas maiores para a Festa.

O próprio Sr. Francisco Affonso de Mello, festeiro no ano de 1933, lembra do Livro de Ouro, em depoimento incluído em artigo publicado no jornal O Diário de Mogi de 18/05/1975:

${ }^{61}$ O casal de Capitães de Mastro é escolhido, hoje, pelos Festeiros e tem a missão de auxiliá-los na realização da Festa. Como atividade específica dentro da Festa do Divino, os Capitães de Mastro têm a obrioacão de levantar o Mastro do Divino na vésnera do dominon de Pentecostes 
"Quando fui festeiro era costume da época fazer-se um 'livro de ouro', onde eram assinaladas as contribuições em dinheiro que eram feitas". Nas páginas do seu livro de ouro encontravam-se os nomes das várias pessoas de Mogi, hoje quase todas falecidas. A abertura do livro era a seguinte: "Quer receber as bênçãos do Divino Espírito Santo, contribua de acordo com suas posses para o brilhantismo da festa em seu louvor, assinando neste livro". E o fato de muitas folhas estarem totalmente preenchidas mostra que havia uma integração religiosa bem grande na cidade.

O único Livro de Ouro encontrado no Arquivo Histórico e Pedagógico de Mogi das Cruzes, refere-se ao ano de 1938. Trata-se de um caderno de capa dura e estofada que mede cerca de $15 \times 21 \mathrm{~cm}$. Sobre a sua cor vermelha está escrito em dourado: "Livro de Ouro da Festa do Divino Espírito Santo de Mogy das Cruzes 1938”. O interessante é que neste Livro não constam palavras iniciais como no relato do Sr. Francisco, tampouco os nomes dos Festeiros do ano ${ }^{62}$. Logo na primeira página, consta o maior valor doado: 1:000\$000, pelos empregados do Depósito Antartica de Mogy das Cruzes; nas páginas seguintes, os valores vão diminuindo, aumentando o número de doadores. A Cia. Antartica Paulista e a So. Coop. Japoneza de Mogy das Cruzes contribuíram com $400 \$ 000$ e 100\$000, respectivamente. Das contribuições pessoais, destacaram-se o Sr. José Correa, com $500 \$ 000$ e o Sr. Bento Mora com o valor de 320\$000. Somam-se 81 pessoas que doaram de $200 \$ 000$ a 50\$000, 101 que contribuíram com valores entre $20 \$ 000$ e $30 \$ 000$, e finalmente 128 pessoas doaram $5 \$ 000$ e 10\$000. Ao final do Livro de Ouro ${ }^{63}$, estão registradas as doações de alimentos, provindas de mercados e açougues: quilos de carne, sacos de arroz e café, bezerros, porcos, garrotes, leitoas, etc.

Parte destes alimentos doados estava destinada à confecção da charola: um andor constituído por uma grande armação redonda feita de bambu, e carregada de alimentos. Ao final da Festa era sorteada entre os devotos, e o Festeiro distribuía moedas às crianças ${ }^{64}$. Em 1935, foram doados cerca de dois mil cobertores aos pobres, além da doação de dez a vinte bois para que se pudesse fazer o Afogado. As visitas aos enfermos eram realizadas durante as Alvoradas, quando os Festeiros ofereciam aos doentes rosas e medalhas do Divino (O

${ }^{62}$ Naquele ano, conforme Rodrigues Filho e De Carlo Filho (2004), os Festeiros foram Frederico Straube e sua esposa Ida P. Straube, sem participação de Capitães de Mastro.

63 O Livro de Ouro, segundo Dona Dina - hoje com cerca de 80 anos de idade - foi abolido no ano de 1986, quando foi Festeira, no entanto, matéria publicada no O Diário de Mogi (26/05/1987) revelou que o Livro de Ouro ainda circulava pela cidade no ano seguinte.

${ }^{64}$ Segundo depoimento ao Diário de Mogi, de Dona Antoninha, Festeira de 1979. Descreve a Festa do Divino na década de 1930, especialmente a de 1933 quando seu pai, Sr. Francisco Affonso de Mello foi Festeirn (ODIÁRIO DF MOGI 10/05/1979) 
DIÁRIO DE MOGI, 27/05/1976). A cada ano, alguma coisa era modificada, conforme a disposição, a condição financeira e a posição social do Festeiro. $\mathrm{O}$ fato é que cada um, à sua maneira, praticava a distribuição de alguma coisa aos pobres: moedas, cobertores, alimentos, medalhas, doces, etc.

A figura do Bandeireiro do Divino ainda era presente em Mogi das Cruzes na década de 1930, com suas atividades pré-Festa do Divino, de angariar prendas, como lembra Dona Georgina, uma das entrevistadas - hoje, com 90 anos de idade:

A pessoa saía para angariar fundo bem adiantado da Festa [bem antes do início da Festa]. [...] Ele vinha com a bandeira e pedia ajuda, para a Festa do Divino. [...] Ele vinha sempre sozinho. Ele batia, a gente já via que ele estava com a bandeira, entrava e pegava o dinheiro que a gente podia dar. Não era vasilha, era uma sacolinha vermelha também. E ele conversava com a gente, falava porque que ele estava andando, porque que ele estava pedindo. [...] Mas é só, cantar não, ele só pedia e já ia embora para as outras casas. [...] Não entrava, ficava mais na porta. Ele não entrava porque não tinha tempo. Ele precisava estar andando para pegar outra [casa]."

O seu relato refere-se à contribuição em dinheiro para a Festa do Divino Espírito Santo, dada ao Bandeireiro, talvez porque Dona Georgina morava no centro da cidade já naquela época, não tendo condições de ofertar animais e alimentos para a Festa, como em geral acontecia nos bairros rurais.

O Bandeireiro participava, de forma espontânea, da realização da Festa do Divino, sendo que os responsáveis por ela eram os Festeiros, que, já na década de 1930 não arcavam sozinhos com as despesas da Festa. Mais do que a ajuda do Bandeireiro, o casal de Festeiros contava com o auxílio financeiro das empresas instaladas em Mogi das Cruzes, bem como da elite.

Nos anos de 1940 e 1941, o então Vigário havia proibido a participação de grupos de Congada e Moçambique na Festa, mostrando que o Festeiro não tinha poder absoluto sobre ela. Talvez este fato coincida com o início de uma decadência dos festejos, sentida em 1941, quando não houve um casal de Festeiros, mas sim uma Comissão para que a Festa não deixasse de acontecer. Cabe observar que se estava vivendo a II Guerra Mundial até 1945, e posteriormente, a recuperação do mundo pós-guerra, o que provavelmente contribuiu efetivamente para um esmorecimento da Festa (GRINBERG, 1983; RODRIGUES Filho e DE CARLO FILHO, 2004). 
Mais distante da autoridade da Igreja, de forma espontânea, Festas do Divino eram realizadas em localidades rurais. Relata Dona Eulália ${ }^{65}$ que seu pai, o Sr. Aquino, promovia na década de 1940, homenagens ao Espírito Santo no sítio onde morava, as quais duravam três dias, em que não faltavam doces diversos, frutas e, claro, o Afogado, oferecidos aos devotos:

Meu pai se preparava tanto para a festa do Divino! Ele queria as flores todas vermelhas de papel crepom, queria toalha vermelha, queria não sei quê, o mastro... O mastro, que ele levantava mastro para a festa do Divino, então, aquela madeira era uma coisa muito, muito bonita; era assim, uma listra vermelha até lá em cima, e outra listra branca lá no meio. E lá em cima ele punha buquezinho de flor. Só que depois, com o tempo, aquilo ia se acabando, ia derretendo, ia chovendo, ia molhando, ia desbotando. Ai ele queria tirar de lá, mas era muito alto, e colocava a bandeira do Divino pintada por ele, com as asinhas [...] aquele biquinho dourado do Divino com aquelas asas assim, abertas. [...] E a volta da bandeira era todinha de vermelho, e tudo bem pregadinho com tachinha".

As rezas eram ministradas por um capelão ${ }^{66}$, mas as danças de Moçambique ficavam sob os cuidados do Sr. Aquino que, além da devoção, exigia de todos os integrantes do grupo sobriedade, boa apresentação com seus uniformes brancos e seus instrumentos.

Após a Guerra, foram introduzidas as lanternas (feitas com armação de madeira, e velas no seu interior) nas Alvoradas, conforme relata o Sr. Roberto, hoje condutor do grupo de pessoas que as carrega durante as procissões:

Logo depois da segunda guerra, o pessoal veio com um monte de idéia, $e$ ai a lanterna é por causa disso, por causa da péssima iluminação, porque era iluminação incandescente na época. Hoje é lâmpada de mercúrio... naquela época era lâmpada incandescente, então não iluminava, eram aquelas ilhas de iluminação. Tinha bairros que não tinham iluminação. E a Alvorada naquela época, viajava, andava nos bairros [...]. Saía bem de madrugada e voltava [já] bem cedo, porque andava bastante. [...] $O$ pessoal foi ficando mais idoso, [...] e foi diminuindo o itinerário.

Já na década de 1950, e sob a política desenvolvimentista do então Presidente da República Juscelino Kubtscheck, o processo de industrialização foi acelerado, aceleração que se intensificou na década de 1970, sob a ditadura. Nesta fase da industrialização, a preferência das empresas era por localizações próximas às rodovias em detrimento das ferrovias, para escoar sua produção. A região do Grande ABC (constituído, sobretudo, pelos

${ }^{65}$ Hoje com 70 anos de idade. 
municípios de Santo André, São Bernardo do Campo e São Caetano do Sul), juntamente com Guarulhos e Noroeste da Capital, nas décadas de 1950 e 1960, começaram a atrair capital tornando-se grandes e sólidos pólos industriais da metrópole paulistana (Plano Diretor do Município de Mogi das Cruzes - 1999/2005: 28). Quanto ao município de Mogi das Cruzes, em 1952, a Prefeitura tentou atrair maiores investimentos para a cidade, oferecendo isenção de impostos às novas indústrias que ali quisessem se instalar $\left(\right.$ GRINBERG, 1961) ${ }^{67}$. Outro atrativo a essas empresas era a inauguração, em 1951, da BR 116, a Rodovia Presidente Dutra, ligando São Paulo ao Rio de Janeiro, passando próximo ao município $^{68}$ (Mapa 2). No ano seguinte a ELGIN, fábrica de máquinas de costura se instalou na cidade (GRINBERG, 1961); em 1959 chegou a NGK (cerâmica e velas de ignição), na década seguinte a VALTRA (ou VALMET) e a Aços Anhanguera S/A (atual Aços Villares) ${ }^{69}$. Ainda podemos citar: Howa do Brasil S/A Indústria Mecânica (máquinas para indústria têxtil), Indústria de Papel Simão S/A, VULCAN Material Plástico S/A, Cia. Industrial Mogiana de Tecidos, Sedas Gutermann S/A e a Indústria de Pianos Schwarztmann $S / A^{70}$. É relevante observar que as indústrias atraíam migrantes de outros municípios e estados, a procura de emprego e melhores condições de vida, o que veio a contribuir para o crescimento populacional da cidade.

Talvez tal quadro de "euforia" desenvolvimentista tenha contribuído para um esmorecimento da Festa, que, pelo seu caráter religioso popular, se contrapunha à modernidade que avançava.

Mas mesmo com dificuldades, o Espírito Santo era homenageado de forma festiva. Conta Dona Emília da Silva Pires que, embora solteira, foi Festeira em 1958, para que a Festa fosse realizada. E em meio às dificuldades, conseguiu manter os carros de bois, a Quermesse no Largo da Matriz (atual Catedral de Santana), e a Alvorada que durou apenas três dias (O DIÁRIO DE MOGI, 03/06/2001).

${ }^{66}$ Designa-se capelão a pessoa autorizada pelo Bispo a ministrar rezas e cuidar de capelas, porém não possui a mesma autoridade e as mesmas atribuições de um Padre.

${ }^{67}$ Vale lembrar que entre as fábricas mais antigas de Mogi das Cruzes estava a Mineração Geral do Brasil, instalada em 1942.

${ }^{68}$ A ligação do município de Mogi das Cruzes com a Rodovia Dutra ocorreu na década de 1970, a partir da construção da estrada municipal Mogi-Dutra, durante a gestão do então prefeito Waldemar Costa Filho (www.pmmc.com.br).

${ }^{69}$ Conforme mostrou a análise das entrevistas, complementada pela consulta ao site da Prefeitura Municipal de Mogi das Cruzes: www.pmmc.com.br - acesso em março de 2007.

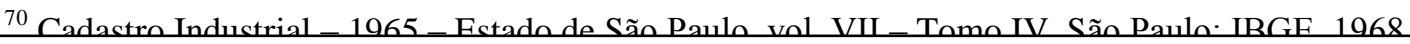


Naquela época, muitos dos elementos da Festa estavam preservados da mercantilização, como lembram Dona Maria José e o Sr. Miled ${ }^{71}$ : a Casa da Festa, local onde se concentrava a cozinha da Festa, bem como a confecção de ornamentos etc., ficava nas proximidades ou na própria igreja de Santana, e estava sempre aberta durante o período festivo. Ali se dava o acolhimento de devotos com um prato de comida, tirado do fogão a lenha, que nunca se apagava durante a Festa. Doces e salgados feitos na Casa da Festa eram distribuídos à população a qualquer hora do dia.

Conta o Sr. Josemir ${ }^{72}$ que na década de $1960^{73}$, a Festa do Divino era simples, sem ostentações; lembra que os grupos de Congada e Moçambique se apresentavam, inclusive durante a Entrada dos Palmitos. O Sr. Roberto - provavelmente com sete anos de idade em 1960 - recorda da Festa do Divino da sua infância:

Tinha essa parte da Alvorada, à noite a Novena. Quando vinha chegando, por exemplo, no sábado, quando tinha o Afogado, na parte da tarde tinha os folguedos. Então eu, meus irmãos, meu pai e minha avó fomos passando para o pessoal. Fazia sebo para colocar no pau de sebo. Então tinha essa parte de jogos, folguedos. Então tinha lá corrida com ovo. Tinha bolinha de gude, fazia balanço...

Após o Golpe de 1964, quando os Militares tomaram o comando do País, tendo à frente Camilo Castelo Branco, as notícias sobre a Festa foram rareando, mas ainda assim, tornou-se pública a proibição de fogos de artifício, pau de sebo e porco ensebado nas festividades, mantendo-se o Moçambique e a Congada, e algumas brincadeiras como quebra-potes, ovo na colher e corrida de saco (O DIÁRIO DE MOGI, 29/05/1965).

No movimento de chegada de indústrias no município, a cidade cresceu transformando a vida de seus moradores, até aquele momento ainda muito marcada pelos eventos religiosos como procissões, festividades, novenas, etc. O modo de vida "pacato" contrastava com o processo de urbanização que avançava em Mogi das Cruzes. As manifestações religiosas populares surgiam, agora, aos olhos de muitos, como um "atraso", com suas procissões "pitorescas" que atrapalhavam o trânsito.

${ }^{71}$ Ambos possuem hoje, cerca de 80 anos de idade, e foram Festeiros em 1993. Participam da Associação Pró-Festa do Divino, sobre a qual trataremos detalhadamente no próximo capítulo.

${ }^{72}$ O Sr. Josemir, com aproximadamente 65 anos de idade, também é um dos coordenadores da Associação Pró-Festa do Divino Espírito Santo.

${ }^{73}$ Em 1960 foi fundado o jornal O Diário de Mogi, importante fonte de dados sobre a Festa do Divino em Mogi das Cruzes. No início, os artigos que cobriam a Festa eram tímidos, constituindo-se 
$\mathrm{Na}$ década de 1960, duas das escolas de $1^{\circ}$ e $2^{\circ}$ graus de Mogi das Cruzes começaram a atuar também no $3^{\circ}$ grau. A Sociedade Civil de Educação Braz Cubas que iniciou suas atividades no ensino superior com a Faculdade de Direito Braz Cubas, obteve em 1983 o reconhecimento como Universidade Braz Cubas ${ }^{74}$. Já a OMEC - Organização Mogiana de Educação e Cultura, com a instalação de cursos superiores, passou a ser UMC Universidade de Mogi das Cruzes, em $1973^{75}$. A paisagem da cidade ia se modificando, pois uma vez as Universidades instaladas próximas à parada Estudantes da estrada de ferro, atraía um contingente significativo de estudantes da região. O mercado imobiliário crescia com as repúblicas, pensões, casas de aluguel; o comércio especializado que visava atender aos universitários começou a se desenvolver, além da vida noturna que se instalava, com bares e botecos voltados aos estudantes.

As festas religiosas em geral, e a do Divino, em particular (pelo fato de ter várias procissões durante a Festa), embora perturbassem as regras de circulação na cidade, se mantinham.

O cortejo, que há muitos anos atrás cruzava as ruas de terra batida, hoje cruza os revestimentos de paralelepípedo e asfalto. E nisso está o grande efeito do tradicional desfile, que desafia o progresso, numa prova de que o passado ainda vive através de uma festa que tem raiz no espírito religioso do povo. (O DIÁRIO DE MOGI, 16/05/1970).

A divulgação da Festa por meio televisivo passou a acontecer, às vezes, por iniciativa dos próprios Festeiros. O caráter "pitoresco" da Festa era usado como chamariz para a população local, para eventuais turistas, para estudiosos do folclore. Portanto, a década de 1970 ficou marcada também pelo discurso dos Festeiros em torná-la cada vez mais atrativa, com a criação de espaço para shows, com ornamentações coloridas, que tornariam o ambiente da Festa mais agradável. Assim, em 1976, foi divulgada a presença de

em pequenas notas com a sua programação, que incluía várias missas no Dia de Pentecostes, a Procissão, a indicação dos novos Festeiros para o ano seguinte (O DIÁRIO DE MOGI, 21/05/1961).

${ }^{74}$ Conforme site da Universidade Braz Cubas: http://www.brazcubas.br, acesso em fevereiro de 2007.

${ }^{75}$ Conforme site da Universidade de Mogi das Cruzes: http://www.umc.br/site.htm, acesso em fevereiro de 2007. 
Inezita Barroso e Tinhorão ${ }^{76}$ na Festa, bem como a participação do Centro de Estudos Folclóricos de Mogi das Cruzes e do Grupo Folclórico Português Estrela de Portugal ${ }^{77}$.

A partir do desejo de Festeiros, no final da década de 1970, de "resgatar" algumas práticas da Festa tal como realizada nos anos de 1930, ressurgem a charola e a distribuição de moedas às crianças (O DIÁRIO DE MOGI, 10/05/1979). A Festa propiciava inovações esporádicas, algumas delas lembradas por Festeiros, em depoimentos dados ao jornal $\mathrm{O}$ Diário de Mogi, como sendo elementos tradicionais da Festa do Divino. Dentre essas práticas eventuais foi relatada a distribuição de Bandeiras do Divino a "pessoas da sociedade", durante missas que antecediam a Festa (O DIÁRIO DE MOGI, 09/05/1976). Talvez fosse essa uma retribuição (ou o reconhecimento) dos Festeiros por um possível "apadrinhamento" da Festa. A colocação de escudos nas portas das casas de ex-Festeiros e devotos que assim o desejassem, pelos Capitães de Mastro durante a Festa do Divino de 1976 aparece como outra atividade isolada, não havendo notícias de tal prática nas Festas anteriores e subseqüentes (O DIÁRIO DE MOGI, 26/05/1976).

A década de 1980 parece ter sido marcada pelo fantasma do fim da Festa (Fotos 610). Para que as homenagens festivas ao Espírito Santo não sucumbissem, o Sr. José Roberto de Deus e sua esposa, Dona Amália Manna de Deus assumiram a responsabilidade de promover a Festa em 1982 e 1984, sendo que em 1983 a festividade havia ficado sob os cuidados de uma comissão de ex-Festeiros (RODRIGUES Filho; DE CARLO Filho, 2004).

De Carlo Filho ${ }^{78}$ (O DIÁRIO DE MOGI, 26/03/1985) entende que, além do falecimento dos mais velhos, há desinteresse dos mais novos em perpetuar os grupos chamados "folclóricos". Observa que os Festeiros se mantinham tão preocupados com a Quermesse e a coleta de recursos que se esqueciam do restante da Festa, principalmente da parte que ele chamava de folclórica. Parece que De Carlo Filho vinculou o sucesso da Festa às atividades folclóricas, que se destacariam como ornamentação, como a parte "pitoresca", com o objetivo de chamar a atenção de devotos, curiosos, estudiosos e turistas. Uma vez o “cartão de visitas" fraco, a Festa tenderia ao insucesso. A solução então seria investir no

${ }^{76}$ Inezita Barroso e José Ramos Tinhorão são famosos pela dedicação à cultura caipira, ao folclore brasileiro e à música do homem do campo.

${ }^{77}$ Com base em pesquisa realizada no jornal O Diário de Mogi da década de 1970, referente aos meses de maio e junho.

78 Festeiro do Divino de Movidas Cruzes no ano de 1985 
"espetáculo" da Festa, para atrair não só devotos locais como também, turistas, já que ela havia sido incorporada ao Calendário Turístico de Mogi das Cruzes ${ }^{79}$.

A programação da Festa do Divino deste ano está sugerindo uma boa nova: o retorno de tradições folclóricas que estavam, já há muito tempo e ano a ano, caindo no esquecimento. Será que teremos uma comemoração completa, ou seja, com o folclore presente, o máximo possível, nessa comemoração? (DE CARLO Filho apud RODRIGUES Filho; DE CARLO Filho, 2004: 8).

Talvez pela necessidade de um destaque do componente "folclórico" da Festa, tivesse havido um reconhecimento de Nhá Zefa ${ }^{80}$ como uma representante dos devotos do Divino, pois já era famosa entre os mogicruzenses, pelo fato de ser uma mulher independente ${ }^{81}$. Ela costumava desfilar na Entrada dos Palmitos, durante a Festa do Divino, montada em seu cavalo enfeitado com flores de papel crepom, carregando a Bandeira do Divino $^{82}$ (Foto 7). Porém jamais exerceu atividades vinculadas a alguma Paróquia, tampouco foi voluntária da Festa seja na confecção de doces e salgados, seja em qualquer outra atividade. Ela simplesmente, de forma espontânea, participava da Entrada dos Palmitos anualmente.

Conforme entrevista realizada com José Luís, mais conhecido como Rabicho ${ }^{83}$, Nhá Zefa conquistou naturalmente seu "espaço" na Festa do Divino, tornando-se visível para a sociedade também no período de não-Festa, já que seu costume de andar descalça, de usar calças compridas, de colocar um chapéu sobre o lenço que envolvia a cabeça chamavam atenção e a identificavam. Mais do que uma simples devota, segundo Rabicho, Nhá Zefa simboliza outros grandes personagens de Mogi das Cruzes, e tornou-se a personagem da cultura popular que "desembarcou" na Festa do Divino, em torno de quem

${ }^{79}$ Lei n. 2.890 de 25 de fevereiro de 1985 (RODRIGUES Filho; DE CARLO Filho, 2004:6).

${ }^{80}$ O nome verdadeiro de Nhá Zefa é Josefina Franco de Carvalho, nascida em 1902 e falecida em 1991. No entanto, seus familiares alegam que ela nasceu antes da data do registro de nascimento e, desta forma, tenha falecido com mais de noventa e oito anos de idade (RODRIGUES, 2006).

${ }^{81}$ Nhá Zefa morava em um casebre localizado onde hoje está o prédio da Prefeitura no Bairro Shangai, próximo ao centro da cidade. Ali ela criava seus cavalos, plantava seus alimentos, e vendia o excedente. conforme entrevista realizada com Dona Cida, que mora em Mogi das Cruzes há mais de 40 anos.

${ }^{82}$ Conforme entrevista realizada com o Sr. Josemir.

${ }^{83}$ Hoje, com 50 anos de idade, Rabicho, juntamente com Pedro do Carmo, foi produtor do CD "A Festa do Divino em Mogi das Cruzes", feito com o objetivo primeiro de gravar a trilha sonora do documentário "Divino Fsnírito Powlar" de 2004 
se alimentam várias lendas. Uma delas é a de que ela se transformava em uma onça, daí Nhá Onça, ou Nhá Zefa Onça.

Foi homenageada pelos Festeiros de 1986 (O DIÁRIO DE MOGI, 18/05/1986) e, após a sua morte, foi carinhosamente lembrada no vídeo produzido em 2004 por Pedro do Carmo Abib, intitulado "Divino Espírito Popular". Hoje seus descendentes desfilam na Entrada dos Palmitos carregando uma faixa com os dizeres: "FAMILIARES DA NHÁ ZEFA - Filhos, netos, bisnetos e tataranetos", em sua homenagem ${ }^{84}$.

A riqueza da cultura popular está nas "Nhás Zefas" que vivem a Festa do Divino, e mais do que isso, vivem as Festas de Mogi das Cruzes, na singeleza de atitudes, na alegria de participar, na espontaneidade festiva e na religiosidade.

Diante da preocupação com o turismo e com a espetacularização da Festa do Divino de Mogi das Cruzes, a cultura popular começava a ser ameaçada pelo processo de transformação da Festa em espetáculo, já anunciado no final da década de 1980.

A década de 1980 foi fechada com os Festeiros Sr. Jurandyr Ferraz de Campos e D. Marlene Pinto Campos. Historiador, o Sr. Jurandyr teve a preocupação de resgatar alguns elementos, que considerava perdidos, da tradição da Festa, como a presença do menino Imperador, ou melhor, do Imperador do Divino nas Procissões de Abertura da Festa e de Pentecostes, e na Entrada dos Palmitos. O Imperador foi, nos primeiros anos, escolhido a partir de uma redação proposta nos grupos de catequese das igrejas (O DIÁRIO DE MOGI, 04/05/1989). Hoje, a escolha do menino Imperador e da menina Imperatriz (representando Dom Diniz e Dona Isabel, reis de Portugal), é feita pelos Festeiros, podendo ser seus parentes, inclusive ${ }^{85}$.

As opiniões dos entrevistados sobre a Festa na década de 1980 são bastante divergentes. Ana ${ }^{86}$, por exemplo, percebeu que justamente naquele momento a Festa estava mudando o seu caráter, pois se destacavam muito mais as "atrações" folclóricas e a pomposidade nas procissões, do que a religiosidade. $\mathrm{O}$ discurso de retomada da Festa através de investimentos no "folclore", juntamente com a sua inserção no calendário turístico municipal parecia ter surtido efeito no sentido de atrair pessoas não só como expectadoras, mas também como organizadoras. Já para Carlos Henrique, mais conhecido

${ }^{84}$ Para saber mais sobre Nhá Zefa, consultar Rodrigues (2006).

${ }^{85}$ Conforme entrevista com Sr. Reginaldo, 53 anos, Festeiro do Divino de 2005.

86 Fm meados de 1980 Ana estava com cerca de 30 anos de idade 
como Caíque ${ }^{87}$, a Festa do Divino da década de 1980 fazia parte efetiva da vida das pessoas que dela participavam. Cabe observar que, como lembranças da adolescência de Caíque, a respeito da Festa do Divino, podem refletir um olhar menos maduro do que o de Ana.

A década de 1990 é marcada pela criação, após a realização da festividade de 1994, da Associação Pró-Festa do Divino ${ }^{88}$. Naquele ano, durante a Festa, foi distribuída à população uma espécie de apostila intitulada "Tradicional Festa do Divino Espírito Santo", com textos explicativos sobre as origens da Festa do Espírito Santo e seus símbolos. Também foi distribuída uma história em quadrinhos "ReConhecer a Festa do Divino", confeccionada com o apoio da Secretaria Municipal de Educação e Cultura de Mogi das Cruzes e Universidade Braz Cubas. O intuito era o de trazer, para conhecimento da população, as origens da Festa do Divino Espírito Santo e os símbolos nela envolvidos.

Cabe observar que até o final da década de 1980, as quermesses da Festa do Divino eram realizadas na Praça da Catedral de Santana, tendo sido deslocada para o Centro Cívico (Prefeitura) em $1990^{89}$ (Mapa 4 ). O Império do Divino que era montado na casa dos Festeiros ou Casa da Festa nas proximidades da Catedral de Santana, passou a funcionar na própria Praça da Catedral, sendo montado e desmontado a cada Festa, desde 1994.

Essas mudanças espaciais configuram uma dispersão da Festa, que no início do século XX, estava concentrada na Catedral de Santana, em todos os seus momentos. A fragmentação é mais sentida quando a Quermesse é "desprendida" da Festa, tornando-se quase que outra Festa com o mesmo tema, distante que ficou da igreja, chegando em 2003 a ser realizada no Centro de Iniciação Profissional ${ }^{90}$ (CIP), próximo às Universidades Braz Cubas e de Mogi das Cruzes (Mapa 4).

Empresas como Spal, Semetal, Hoescht, Universidade de Mogi das Cruzes, Universidade Braz Cubas, Loja Itaipu, Banco do Brasil começaram a investir como apoiadores ou patrocinadores da Festa (O DIÁRIO DE MOGI, 25/05/1995). Configurava-se

${ }^{87}$ Conforme entrevista realizada. Festeiro do Divino aos 26 anos de idade, em 2000, Caíque hoje participa da Associação Pró-Festa do Divino.

${ }^{88}$ Desde então a Festa começou a ter maior evidência na região de Mogi das Cruzes, conforme veremos logo adiante.

${ }^{89}$ Todas as informações sobre os locais envolvidos na realização da Festa do Divino a partir de 1960 foram obtidas através de consulta às edições do Diário de Mogi dos meses de maio e junho, de 1960 a 2006.

${ }^{90}$ O CIP funciona no Centro Municipal Integrado "Deputado Maurício Nagib Najar", e oferece cursos rápidos (datilografia e panificação, dentre outros) a adolescentes de famílias carentes (Plano Diretor do Municínio de Movidas Cruzes 1909/2005) 
o setor de marketing da Associação Pró-Divino, que contribuiu para que a Festa mudasse definitivamente de caráter. No lugar de uma manifestação da religiosidade local (popular e de segmentos da elite), a Festa passou a envolver interesses de empresas, de políticos que comandam a sua organização.

No ano de 2000, com o início das atividades da TV Diário ${ }^{91}$, a divulgação da Festa foi intensificada, tendo a Associação Pró-Divino se solidificado e se tornado primordial para a realização da Festa. As festividades, por sua vez, foram ganhando contornos cada vez mais espetaculares, condizentes com a realidade urbano-industrial na qual se inserem.

91 Afiliada à Rede Globo de Televisã

\section{pdfMachine}

A pdf writer that produces quality PDF files with ease!

Produce quality PDF files in seconds and preserve the integrity of your original documents. Compatible across nearly all Windows platforms, simply open the document you want to convert, click "print", select the "Broadgun pdfMachine printer" and that's it! Get yours now! 
MAPA 4: LOCAIS DE QUERMESSES

(FESTAS DO DIVINO DE MOGI DAS CRUZES - 1961 A ATUAL)

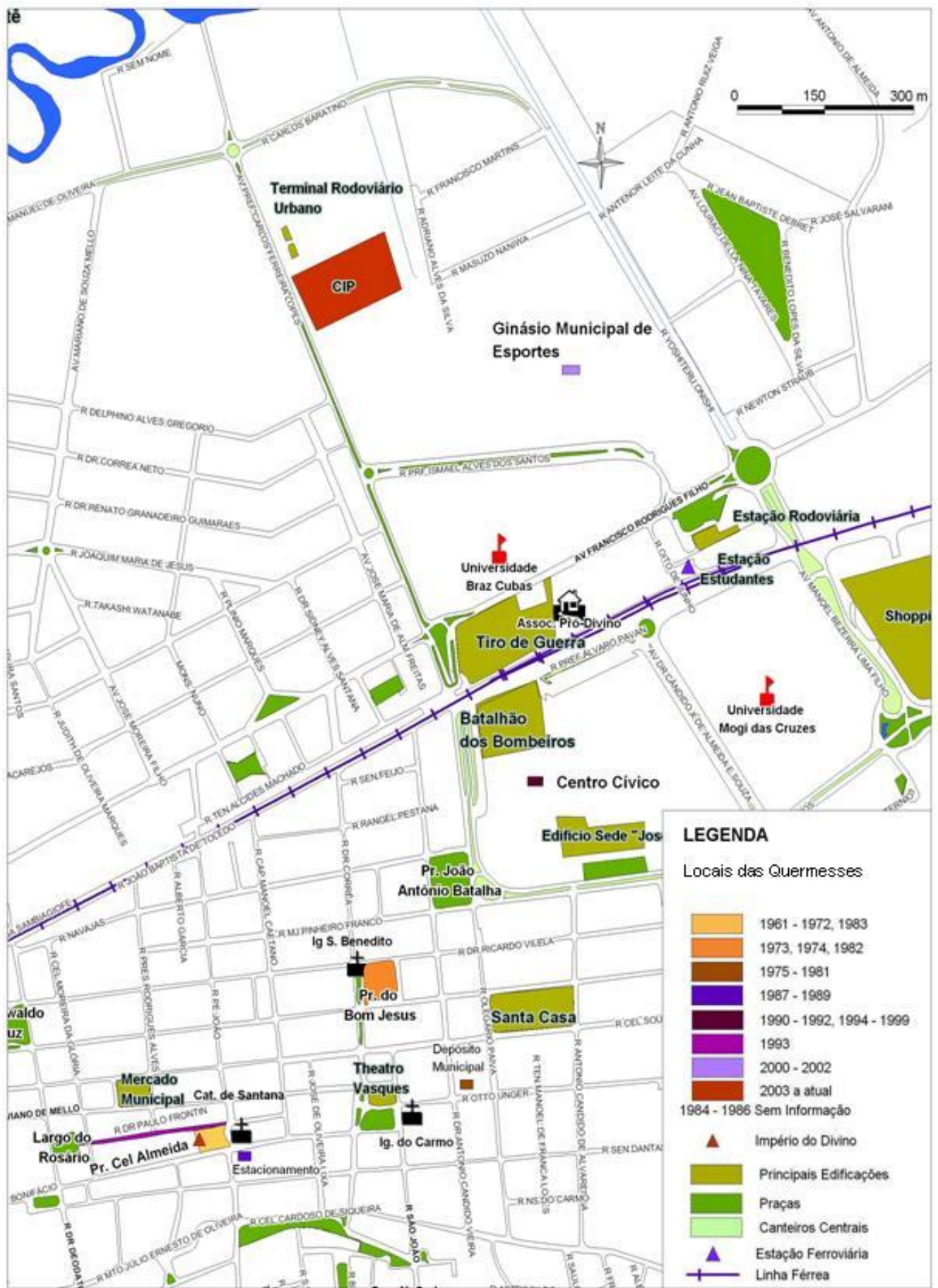

Elaboraçào: Geog. Rinaldo Gomes Pinho e Neusa de Fátima Mariano

Fontes: Centro da Cidade (1: 10.000). Mogi das Cruzes: Secretaria Municipal de Planejamento e Urbanismo - Divisåo de Geoprocessamento. 2006 O Diário de Mogi. Mogi das Cruzes: maiojunho, 1960 - 2006

pdfMachine

A pdf writer that produces quality PDF files with ease!

Produce quality PDF files in seconds and preserve the integrity of your original documents. Compatible across nearly all Windows platforms, simply open the document you want to convert, click "print", select the 


\section{Festa do Divino Espírito Santo em Santa Isabel ${ }^{92}-1933$}

Durante a Missão de Mário de Andrade, foram filmadas na década de 1930, várias manifestações da religiosidade popular também na região de Mogi das Cruzes. As imagens foram obtidas a partir de filmagem feita por Artur Pereira em 04/06/1933, intitulada "Festa do Divino Espírito Santo de Santa Isabel”. Não foi possível obter imagens da Festa do Divino de Mogi das Cruzes porque o filme ainda não foi digitalizado pelo Centro Cultural São Paulo, detentor deste acervo, o que dificulta a transformação da imagem filmada em fotografia. Já naquela época, os grupos de Congada alegravam os festejos com a devoção expressa em sua dança.

Foto 3.

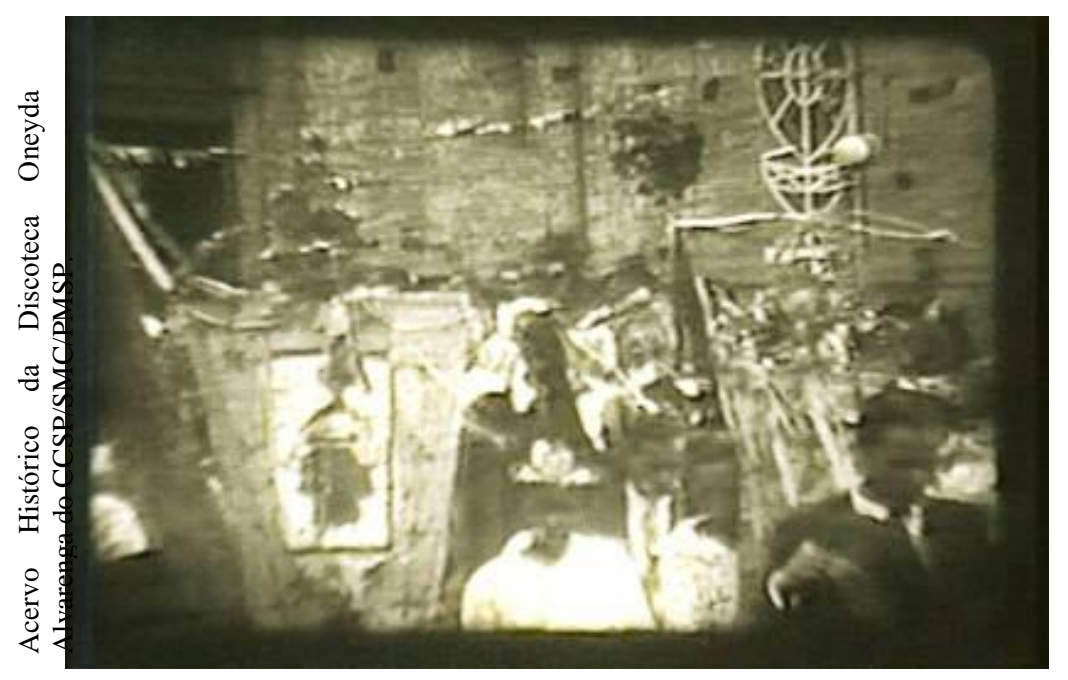

92 Municínio limítrofe de Mooi das Cruzes 
Foto 4.

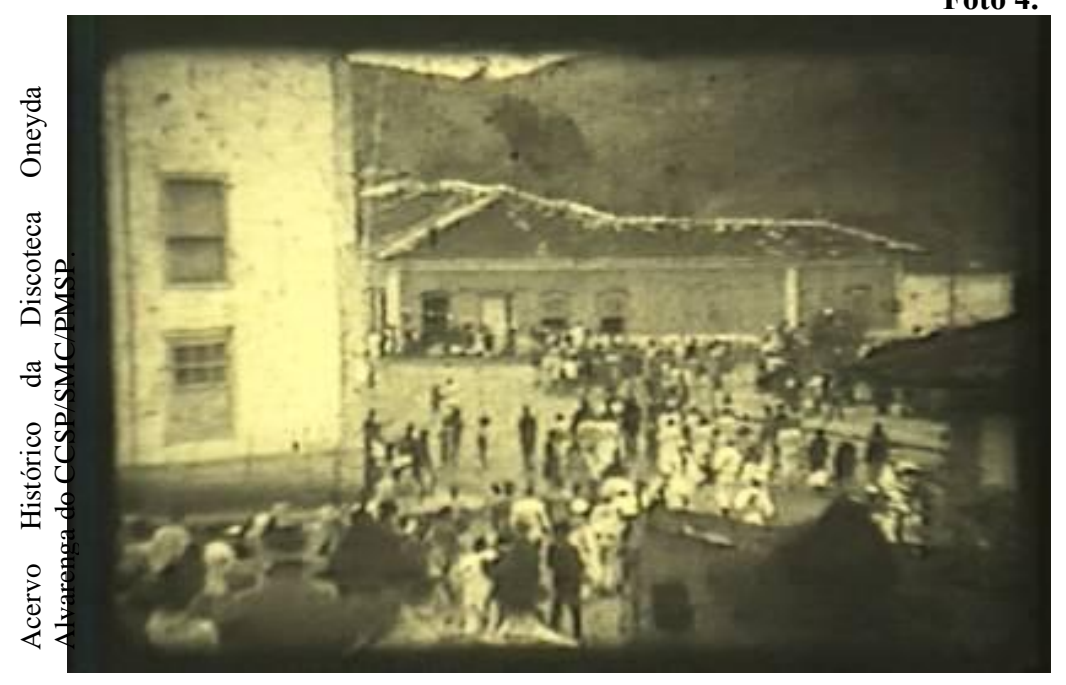

Foto 5.

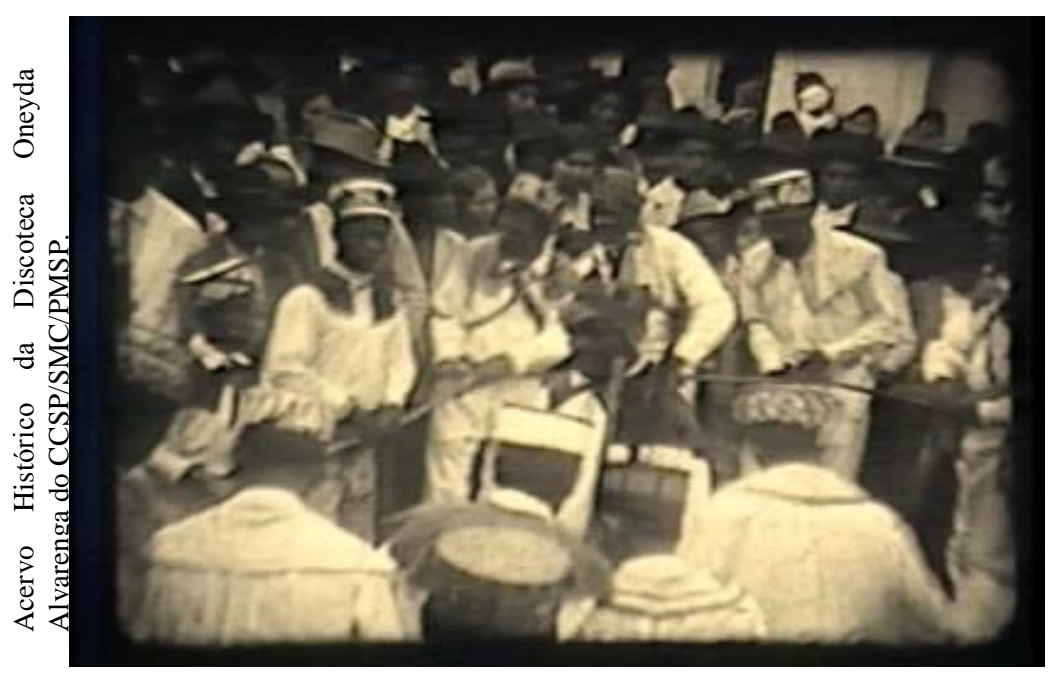

\section{pdfMachine}

A pdf writer that produces quality PDF files with ease!

Produce quality PDF files in seconds and preserve the integrity of your original documents. Compatible across nearly all Windows platforms, simply open the document you want to convert, click "print", select the "Broadgun pdfMachine printer" and that's it! Get yours now! 


\section{Foto 6.}

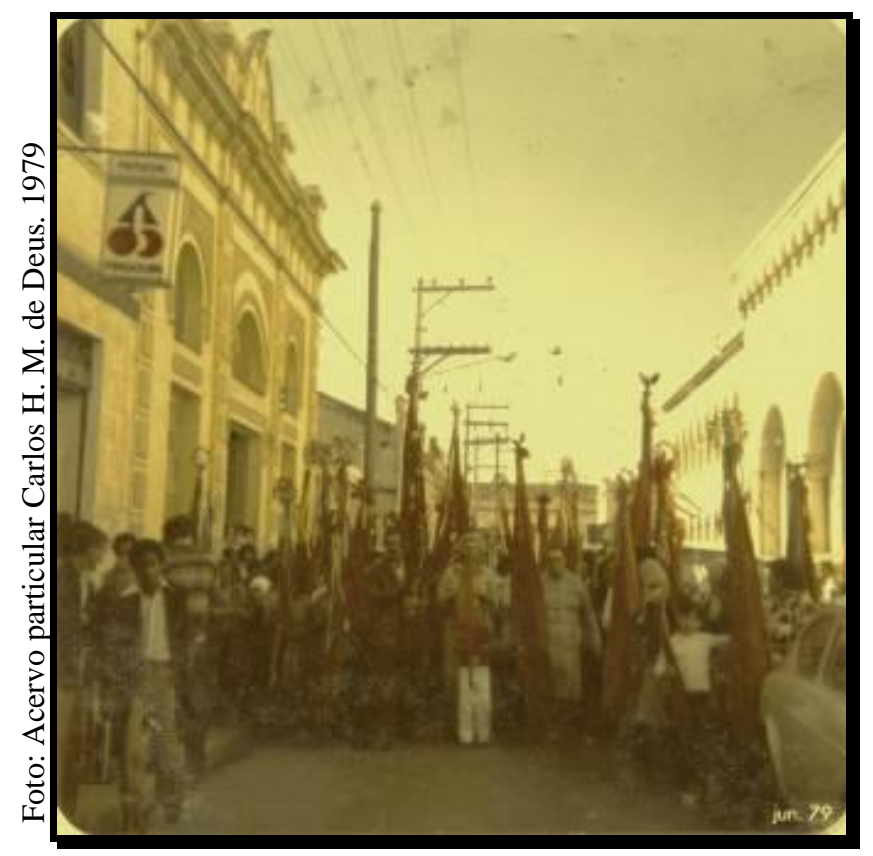

Bandeiras vermelhas, contendo a imagem de uma pomba no topo, na saída de uma procissão.

Foto 7.

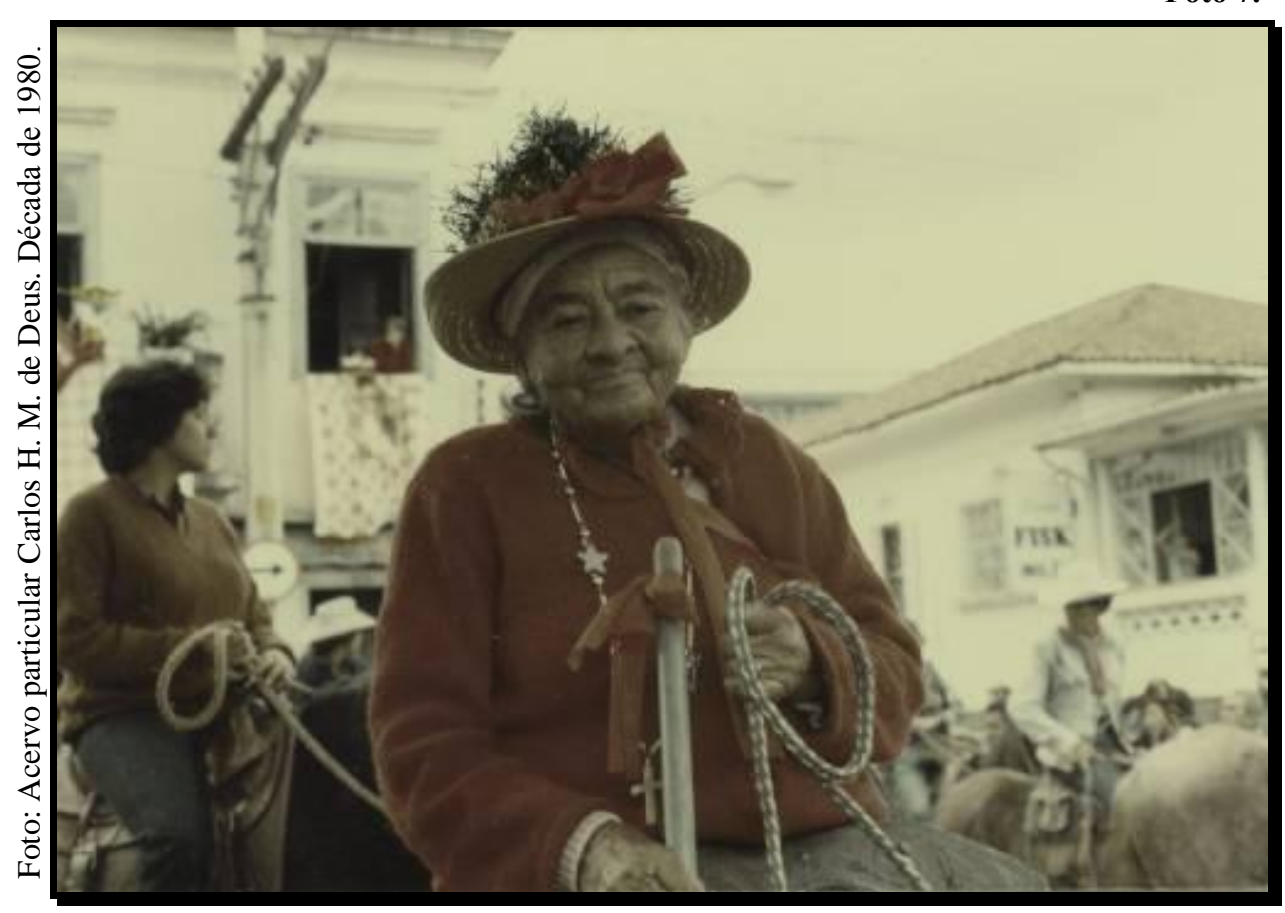

Acho que a figura de Nhá Zefa é isso, sintetiza essa coisa, do cidadão popular e forte.

José Luís (Rabicho)

\section{pdfMachine}

\section{A pdf writer that produces quality PDF files with ease!}

Produce quality PDF files in seconds and preserve the integrity of your original documents. Compatible across nearly all Windows platforms, simply open the document you want to convert, click "print", select the "Broadgun pdfMachine printer" and that's it! Get yours now! 
Eu participava disso como um menininho que vinha em cima dos carros dos bois, em cima dos palmitos. [...]. Não tinha nenhum sentido religioso, nem

participativo. Era simplesmente que a gente queria vir com os carros de boi.

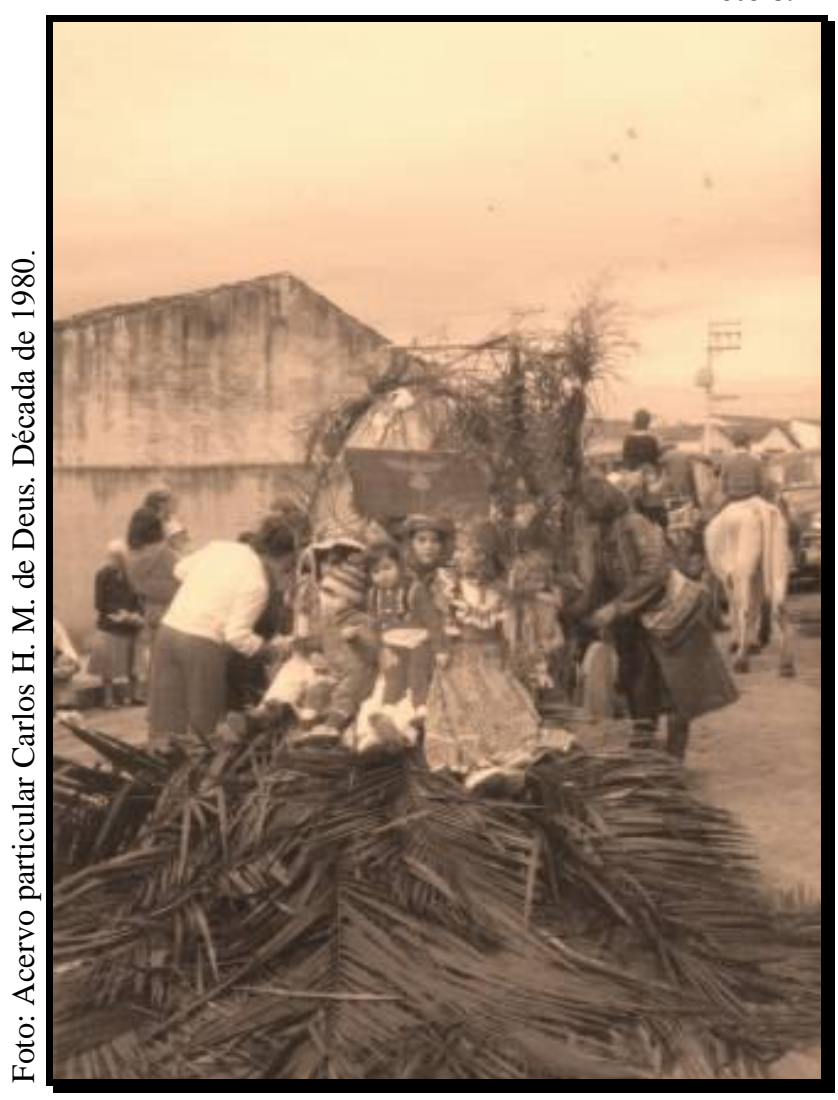

Foto 9.

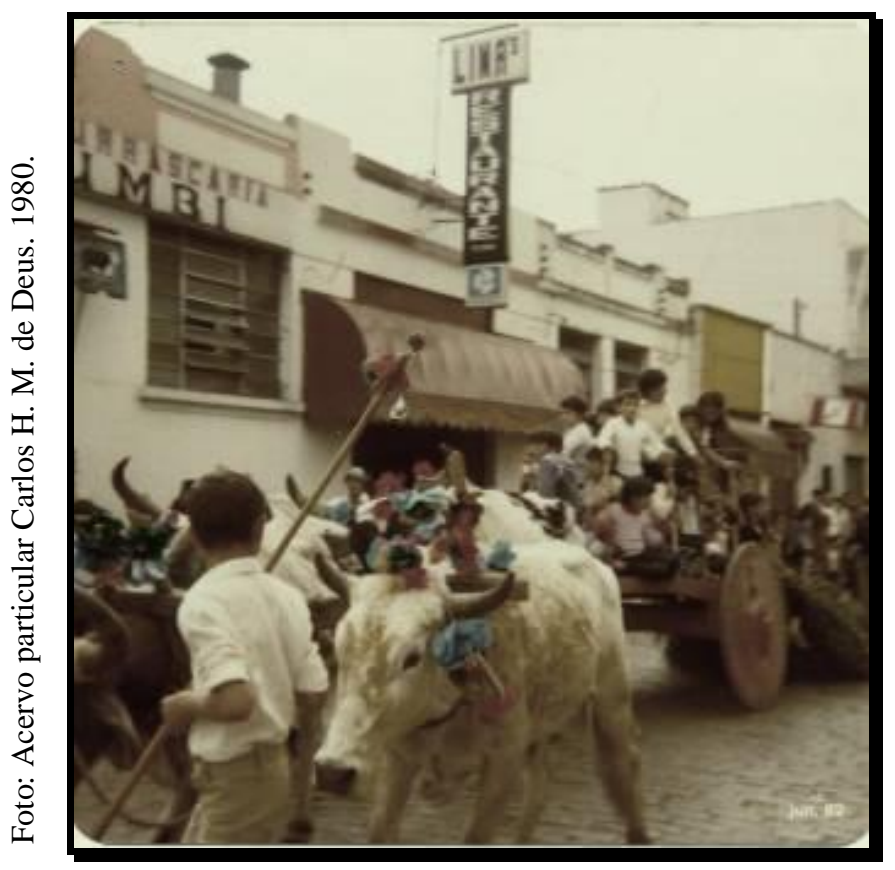

A lembrança que eu tenho: os carros de boi, tudo aquilo... Então, aquilo na cidade pra gente era uma coisa muito gostosa de ver, fazia parte da infância da gente.

Josemir

\section{pdfMachine}

A pdf writer that produces quality PDF files with ease!

Produce quality PDF files in seconds and preserve the integrity of your original documents. Compatible across nearly all Windows platforms, simply open the document you want to convert, click "print", select the "Broadgun pdfMachine printer" and that's it! Get yours now! 
Foto 10.

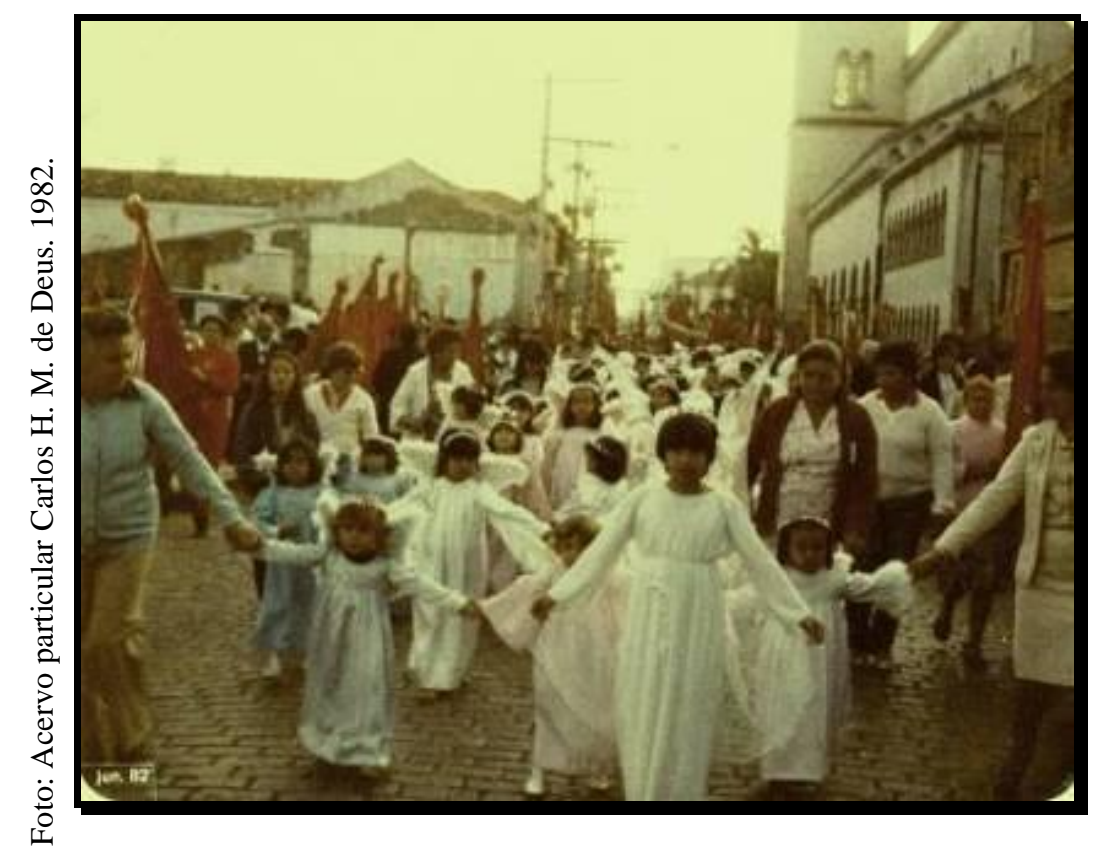

Era comum na Procissão de Pentecostes, vestir as crianças como anjos ${ }^{93} \ldots$

Santana.

Rua José Bonifácio. Ao fundo e à direita, está a lateral da Catedral de

Foto 11.

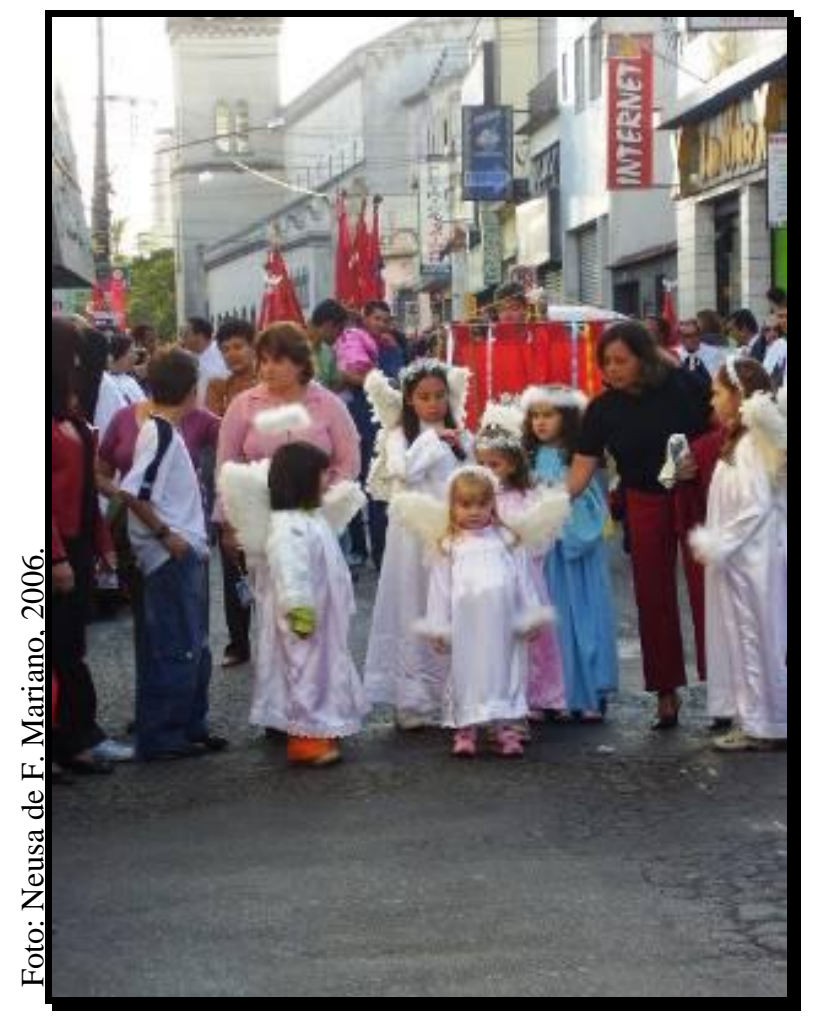

... aliás, como ocorre também nos dias de hoje.

93 Conforme entrevista com $\mathrm{Sr}$ Airton

\section{A pdf writer that produces quality PDF files with ease!}

Produce quality PDF files in seconds and preserve the integrity of your original documents. Compatible across

nearly all Windows platforms, simply open the document you want to convert, click "print", select the

"Broadgun pdfMachine printer" and that's it! Get yours now! 


\section{A ATUal Festa do Divino Espírito SANTo de Mogi daS CRUZeS}

\subsection{Associados pela Festa, para a Festa}

Ela não nasceu por causa da espiritualidade da festa. Ela nasceu e cresce hoje, muito mais em razão do produto material que precisa ser guardado.

Airton $^{94}$

O ano de 1994 marca o início de uma nova fase na Festa do Divino de Mogi das Cruzes, devido à fundação da Associação Pró-Festa do Divino Espírito Santo (Pró-Divino ou Pró-Festa), que vem proporcionando o seu crescimento.

Por mais que possa parecer estranho aos devotos do Divino, a Associação, conforme o Sr. Airton, nasceu em função do acervo patrimonial que os Festeiros deixavam (e que se perdia) após a Festa; a motivação primeira não estava na religiosidade.

Tal acervo patrimonial é constituído por panelas, talheres e outros utensílios domésticos, além de ornamentações, barracas, lonas, etc., que, ao término da Festa, necessitavam ser guardados para reutilização nas festas seguintes.

Acontecia de alguns materiais se perderem, espalhados que ficavam entre os devotos e colaboradores da Festa anterior, cabendo ao Festeiro (que muda a cada ano) "recolher" esse equipamento; sempre faltava alguma coisa que precisava ser adquirida às pressas. A falta de um lugar permanente onde se pudesse concentrar o material utilizado na

94 Presidente da Ascociacão Pró-Divino na oestão $2004 / 2006$ com cerca de 60 anos de idade pdfMachine

A pdf writer that produces quality PDF files with ease!

Produce quality PDF files in seconds and preserve the integrity of your original documents. Compatible across nearly all Windows platforms, simply open the document you want to convert, click "print", select the "Broadgun pdfMachine printer" and that's it! Get yours now! 
Festa impedia um levantamento prévio do que seria realmente necessário comprar; além disso, todo o material teria uma vida útil maior sendo reaproveitado a cada ano.

Com o objetivo de se organizar o que o Sr. Airton chama de "acervo patrimonial" da Festa, ex-Festeiros se juntaram e fundaram a Associação Pró-Festa do Divino Espírito Santo $^{95}$, regida por um Estatuto Social, aprovado na primeira gestão.

Em 1997, a Pró-Divino, como é comumente designada a citada Associação, ganhou um terreno da Prefeitura quando, finalmente, a Casa da Festa tornou-se permanente e pôde,

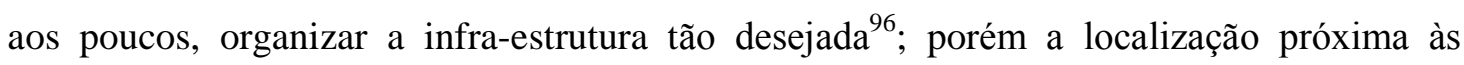
Universidades, é distante do Império do Divino, instalado na Praça da Catedral de Santana, no centro de Mogi das Cruzes. Isto cria dificuldades, por exemplo, para visitas mais freqüente dos devotos à Casa da Festa.

O objetivo inicial da Associação que era guardar e conservar o acervo da Festa acabou por ampliar-se. De auxílio aos Festeiros, facilitando-se o acesso ao material utilizado na Festa, tornou-se, hoje, executora da Festa. A Associação não tem poder de decisão, apenas de execução e orientação dos Festeiros que, por sua vez, devem acatar as determinações do Bispo ${ }^{97}$ Diocesano $^{98}$.

A diretoria da Pró-Divino, com mandato bianual, é composta de Presidente, VicePresidente, Primeiro e Segundo Secretários, Primeiro e Segundo Tesoureiros, Diretores de Assuntos Religiosos, de Assuntos Culturais e Folclóricos, de Assuntos Sociais, e de Patrimônio, além dos Conselhos Fiscal e Consultivo. As coordenações e subcoordenações são formadas conforme a demanda da Festa, sendo que o trabalho de algumas delas tem início quase um ano antes da Festa, como a coordenação de marketing, sobre a qual falaremos mais detalhadamente logo adiante. Subordinados à Diretoria, sempre são

95 “'A Associação Pró-Divino foi declarada de utilidade pública por meio da lei municipal n ${ }^{\circ} 4.828$ de 29 de outubro de 1998, segundo projeto de Lei $\mathrm{n}^{\circ}$ 285/98 de autoria do vereador José Antonio Cuco Pereira" (http://www.festadodivino.org.br - acesso em março de 2007).

${ }^{96}$ No período em que a Associação ainda não possuía uma sede (1994 a 1997), o material utilizado para a realização da Festa continuava sendo responsabilidade dos Festeiros.

${ }^{97}$ Segundo Caíque (33 anos), até 2003, a Associação possuía maior responsabilidade na Festa do Divino do que a que possui hoje, pois as contratações de serviços que o evento demanda passaram a ser executadas pela Mitra Diocesana, que se tornou o órgão responsável pela Festa. Ao final da Festa, o dinheiro que sobra do que é arrecadado na Quermesse (depois de efetuados os devidos pagamentos às entidades que montaram barraquinhas na Quermesse) é enviado à Mitra Diocesana.

${ }^{98}$ A Diocese de Mogi das Cruzes, criada em 1962 pelo Papa João XXIII, abrange os municípios de Poá, Suzano, Ferraz de Vasconcelos, Itaquaquecetuba, Arujá, Guararema, Salesópolis, Biritiba Mirime Santa Isabel (httn / w www diocesedemovi oro hr - acesso em marco de 2007) 
necessários coordenadores para as procissões, para o café distribuído após as Alvoradas, para as ornamentações da Catedral de Santana, do Império do Divino, etc., para a quermesse, para se conseguir patrocinadores através do marketing, para a montagem e desmontagem de infra-estruturas (como por exemplo, o Império do Divino), para a Entrada dos Palmitos, para orientação dos chamados "grupos folclóricos", para a organização de toda a atividade realizada na Casa da Festa (preparação de doces e salgados), para a elaboração do Tapete Ornamental sobre o qual passa a Procissão de Pentecostes ${ }^{99}$.

No ano de 2000, a Associação produziu um "Manual Operacional da Festa do Divino Espírito Santo" para que se mantivesse clara a sua linha de atuação. Além de definir cada parte da Festa (Quermesse, Passeata, Alvorada, Império do Divino, etc.), traça a sua atuação e a de alguns de seus personagens (casais de Festeiros e Capitães de Mastro, Rezadeiras, por exemplo). Em alguns momentos, aponta os problemas mais comuns, na tentativa de superá-los. Termina esclarecendo que o objetivo do Manual é contribuir para o bom andamento e organização da Festa do Divino, devendo ser atualizado sempre, conforme as necessidades do momento. Ao final da Festa, os diretores e coordenadores fazem seus relatórios com o intuito de avaliar o desempenho da Associação, prestam contas à Mitra Diocesana de Mogi das Cruzes, bem como divulgam os dados nos jornais da cidade. Toda essa organização que, em muitos aspectos, é aquela característica de uma empresa, é, ao mesmo tempo causa e conseqüência do crescimento da Festa. Acontece que, a partir da necessidade primeira de organizar o acervo patrimonial da Festa do Divino, a Associação teve que se organizar não só em termos jurídicos, mas também de forma que fizesse a Festa acontecer com cada vez menos dificuldades. Festeiros que tinham pouco conhecimento sobre o funcionamento da Festa, e sobre o seu próprio papel, encontraram na Associação o know how necessário para a sua realização. E nesse aperfeiçoamento a cada ano, principalmente com relação à divulgação atrelada aos patrocinadores e apoiadores, a homenagem do Divino Espírito Santo ganha dimensões maiores quanto a número de participantes, despesas e arrecadações, distribuição de alimentos, cobertura pela imprensa escrita e televisiva, etc.

99 Retomaremos estes itens de maneira mais detalhada no decorrer do trabalho 


\subsection{Começa a Festa antes de a Festa começar}

A Festa do Divino não pode ser reduzida apenas aos onze dias festivos, pois há muita coisa a se fazer, com muito tempo de antecedência. A Associação Pró-Divino, por exemplo, promove na sua sede, nos nove meses que antecedem a Festa, um Chá-Bingo sempre no segundo sábado do mês - com o intuito de levantar recursos para a Festa. O Chábingo proporciona também aos Festeiros a oportunidade de conhecerem toda a equipe da Associação, os voluntários, entre outras pessoas que participam da Festa.

Outra atividade é desenvolvida junto às escolas e ao setor comercial, com o objetivo de angariar prendas (Anexo A) que serão utilizadas tanto no Chá-Bingo quanto no bingo da Quermesse, durante a Festa. A Associação Pró-Divino parece não parar de trabalhar, juntamente com os Festeiros e Capitães de Mastro. Outras atividades consistem na elaboração de bótons, folhetos de rezas, bandeirinhas de papel, e também no estabelecimento de contatos com instituições de caridade, escolas, órgãos públicos, etc., que precisam estar acertados até o dia da Ascensão de Jesus, que marca o início da Festa.

\subsubsection{Festeiros e Capitães de Mastro}

Ah, esse ano o Festeiro é mais do povo, é gente como a gente.

Ele é humilde.

Parece que competem, os Festeiros. Um quer fazer a Festa mais bonita que a do ano anterior.

Como esse Festeiro faz discurso, já é tarde!

Como esse Festeiro é lerdo!

O Festeiro desse ano não conhece a Festa, ele é todo atrapalhado. ${ }_{-}{ }^{100}$

${ }^{100}$ Comentários sobre os Festeiros, ouvidos durante as Festas do Divino de Mogi das Cruzes (2003$2006)$ 
Os preparativos para a Festa começam um ano antes da sua realização, logo que termina a do ano corrente, quando os novos Festeiros são escolhidos pelo Bispo Diocesano, a partir de indicações fornecidas pela Associação Pró-Festa do Divino. Quanto aos Capitães de Mastro, são escolhidos pelos Festeiros e os auxiliarão em suas atividades e decisões ${ }^{101}$.

Os Festeiros antigos entregam aos novos - geralmente anunciados nas celebrações de Corpus Christi - as suas bandeiras (vale lembrar: benzidas) que permanecerão com eles até o início da Festa do ano seguinte, quando as bandeiras dos novos Festeiros já estarão prontas para, finalmente, serem expostas pela primeira vez na Abertura da Festa, quando o Bispo Diocesano as benze, juntamente com as bandeiras dos Capitães de Mastro e dos devotos.

A preferência na escolha do casal ${ }^{102}$ de Festeiros é dada aos que sejam católicos, portanto, tenham sido batizados, crismados e feito a primeira eucaristia. Além destes prérequisitos religiosos, os Festeiros e Capitães de Mastro precisam ser um pouco administradores e ter desenvoltura para levantar recursos para a realização da Festa e para entabular as relações com os órgãos públicos e com empresas. A disponibilidade de tempo para os preparativos da Festa é fundamental, principalmente quando se aproximam os dias festivos propriamente ditos ${ }^{103}$.

Considerados enviados pelo Espírito Santo ${ }^{104}$ para levarem a Sua mensagem aos doentes, às crianças, aos necessitados e aos devotos em geral, o casal de Festeiros é sempre uma boa escolha, conforme os devotos, mesmo que ele desconheça as funções a ele atribuídas e seja, portanto, passível de críticas. A Associação Pró-Divino, conforme explica o Sr. Josemir, um de seus diretores, atua também no sentido de orientar os Festeiros:

${ }^{101}$ Mas nem sempre foi assim, pois na história da Festa já houve a escolha de novos Festeiros por meio de sorteio. Também houve época em que os Festeiros do ano escolhiam o novo casal de Festeiros para sucedê-los. A forma como é eleito hoje o casal de Festeiros tem sido praticada desde 1994, após a fundação da Associação Pró-Divino, conforme entrevista realizada com Dona Maria José.

102 O casal de Festeiros pode ser composto por pessoas solteiras, como foi o caso de Caíque, juntamente com sua então noiva, em 2000, conforme relatou.

${ }^{103}$ Conforme entrevista com Reginaldo.

${ }^{104}$ Apesar de notar que os festeiros possuem certo poder aquisitivo, Dona Maria José e sua filha Márcia - ambas da Diretoria da Pró-Divino - acreditam que eles não são escolhidos por essa razão. $\mathrm{E}$, se os escolhidos têm um certo poder aquisitivo, isso não é por acaso, já que a escolha é, segundo elas, inspirada pelo próprio Espírito Santo. Porém elas também concordam que deveria haver um critério primordial para um casal ser festeiro do Divino: conhecer a Festa como um todo, e nos seus normenores não só da narte relioiosa mas da awe elas chamam de folclórica 
A gente tem que sentar com eles, explicar como se desenvolve a Festa. Obviamente que quando a pessoa já tem um conhecimento da festa é muito mais fácil, ela já tem vivência. Porque, por mais que a gente explique, a pessoa só vai ter a experiência na vivência. Então, a gente até pede, solicita para a autoridade religiosa que olhe para esse fato, que o festeiro tenha uma vivência da Festa. A Associação juntamente com o Festeiro toma a liberdade de sugerir uma série de nomes de casais para o bispo poder escolher. [...] E aí tem aqueles que não tiveram experiência da Festa, mas que conduzem bem porque se amoldam mais, e outros que já dão um pouco mais de trabalho, porque querem ser mais independentes $e$ complicam um pouco o aspecto de manutenção da tradição. Mas, de qualquer maneira, nos últimos anos, a gente tem levado a contento a Festa.

Parece que há certo desencontro entre os requisitos da Igreja e os da Associação quanto à escolha do Festeiro. O Bispo procura católicos praticantes, não necessariamente grandes conhecedores da Festa do Divino e de sua história. A Associação respeita a escolha (cabe lembrar que a escolha se dá a partir de indicação de nomes fornecidos pela Associação) e procura orientar os que não têm a vivência na Festa, mas alguns diretores admitiram que seria melhor que o Bispo escolhesse casais mais envolvidos com a festividade. Corre-se o risco de a Associação se fechar cada vez mais, impedindo a entrada de "novatos", considerados uma ameaça de quebra da tradição, caso não se "moldem", como disse o Sr. Josemir, às orientações da Associação.

É o Festeiro quem dará "cara" à Festa: se ela se apresentará simples ou pomposa, com exageros nas ornamentações, e ainda, se ela enfatizará o caráter religioso ou o folclórico. Mas há práticas que permanecem, entre elas, o compromisso dos Festeiros de visitar, nos dias que antecedem a Festa, hospitais, asilos, orfanatos, creches e residências de devotos, levando a bandeira do Divino (que, antes da Festa é a do Festeiro anterior, conforme já explicado). Relata o Sr. Reginaldo, Festeiro de 2005, sobre sua visita aos hospitais:

Você vai nos quartos de quem quer receber. Porque hoje tem também pessoas que não são católicas que não aceitam, mas... Das visitas, a mais emocionante foi na Santa Casa. Porque são aqueles devotos que participam a vida inteira, e aquele ano estavam lá. Quando a bandeira, na hora que entra no quarto... Nossa!! O que é a fé das pessoas, de beijar a bandeira, beijar a bandeira... e chorar, sabe, sem conseguir falar!

Mônica, Capitã de Mastro de 2006, relata o ritual que se faz nos lugares que 
visitam: primeiramente se explica o logotipo ${ }^{105}$ da Festa, que muda a cada ano (como mostram as imagens logo adiante); reza-se a Coroa do Divino ${ }^{106}$ (Anexo B) e pede-se proteção ao Espírito Santo. Conforme o local, os devotos solicitam que os Festeiros e Capitães de Mastro passem com as bandeiras nas salas do estabelecimento, para que todos sejam abençoados. Os locais visitados sempre montam um Subimpério ${ }^{107}$, (do mais simples ao mais elaborado) que é "inaugurado" pelos Festeiros. Costuma-se distribuir entre os visitados uma medalhinha ou uma pombinha ("Divininho") no alfinete; em algumas instituições como creches e orfanatos, os Festeiros distribuem saquinhos com balas para as crianças.

Para Reginaldo, são tantas as atividades do Festeiro, que ele deveria cuidar somente da parte religiosa, pois entende ser esta a parte gratificante da Festa, principalmente por conta das visitas às instituições e às residências de devotos. Para Mônica, ser Capitã do Mastro lhe proporcionou fortalecer tanto os laços familiares, aproximando pais e filhos, como os de amizade com seus vizinhos e, principalmente com os Festeiros. Além disso, ser Festeiro e Capitão de Mastro proporciona aos casais terem maior conhecimento sobre o funcionamento da Festa do Divino Espírito Santo, já que participam ativamente de todos os seus momentos, administrando inclusive, contas bancárias da Festa.

105 Os Festeiros têm criado, desde 2001 (conforme o Sr. Josemir), logotipos tendo uma pomba branca, a representação do Espírito Santo, em foco. Os logotipos são estampados nos cartazes e outros materiais de divulgação da Festa, os folhetos de programação e de oração, os cadernos de canções das Missas, e as próprias Bandeiras dos Festeiros e dos Capitães de Mastro.

${ }^{106}$ A Coroa do Divino é um tipo de terço, composto por sete Mistérios, sendo invocado em cada um, um dos sete dons do Espírito Santo. Depois de invocar sete vezes o Espírito Santo, em cada Mistério, faz-se uma invocação a Maria. Completados os sete Mistérios, para finalizar, são feitas mais três invocações a Maria. Foi introduzida na Festa do Divino por Dona Amália Manna de Deus, que a trouxe de Minas Gerais, em 1994, conforme entrevista realizada com Caíque.

${ }^{107}$ Império do Divino só existe um, aquele montado na Praça da Catedral de Santana. Demais altares são considerados Subimnérins

\section{pdfMachine}

A pdf writer that produces quality PDF files with ease!

Produce quality PDF files in seconds and preserve the integrity of your original documents. Compatible across nearly all Windows platforms, simply open the document you want to convert, click "print", select the "Broadgun pdfMachine printer" and that's it! Get yours now! 


\section{Logotipos das Festas do Divino realizadas em:}

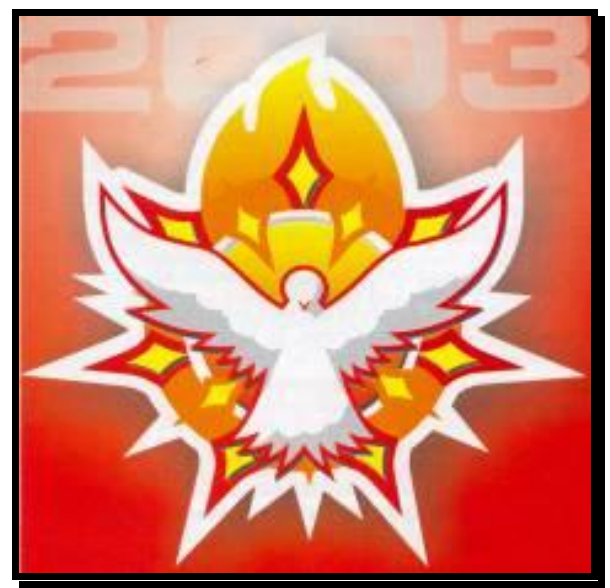

2003

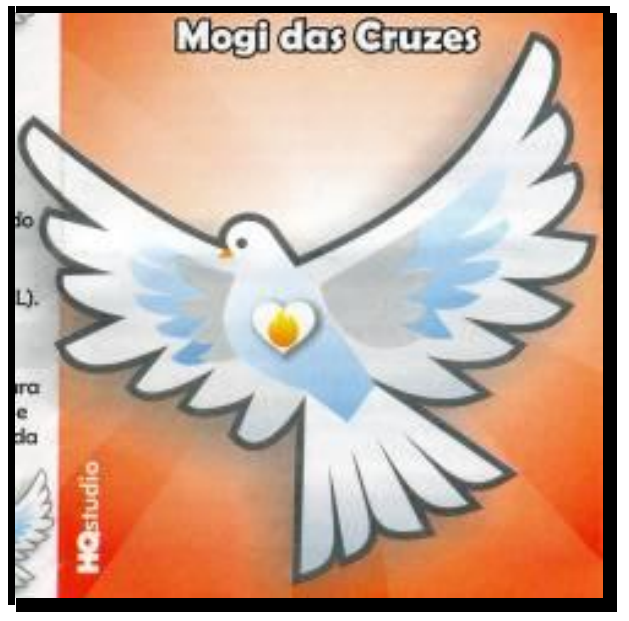

2004

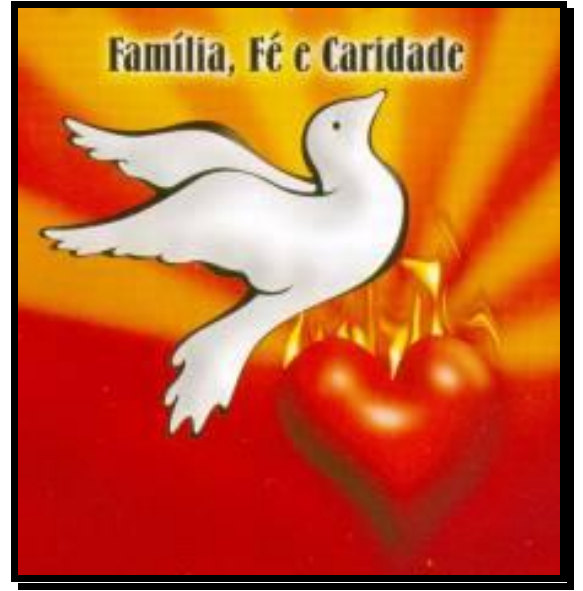

2005

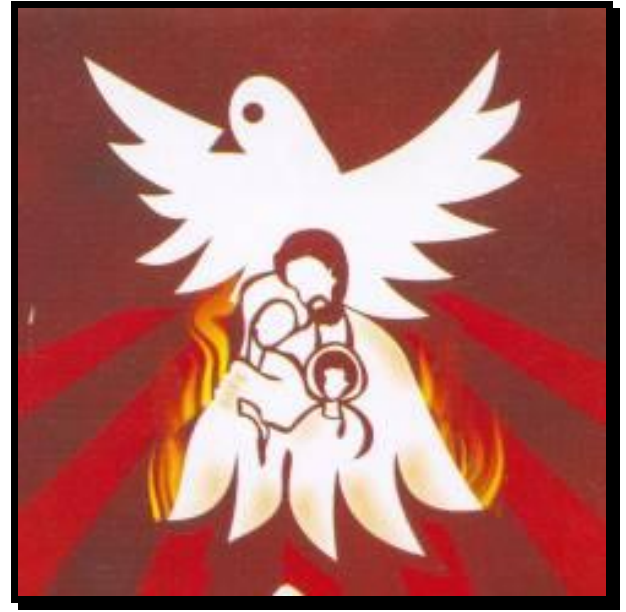

2006

Fonte: Programações e Panfletos de Cânticos distribuídos aos devotos durante as respectivas Festas do Divino de Mogi das Cruzes.

\section{pdfMachine}

\section{A pdf writer that produces quality PDF files with ease!}

Produce quality PDF files in seconds and preserve the integrity of your original documents. Compatible across

nearly all Windows platforms, simply open the document you want to convert, click "print", select the 


\subsubsection{Rezadeiras ${ }^{108}$}

Como eu saía com o Divino primeiro, as pessoas faziam aquele bilhetinho para o Divino e punha nos pés dele. E um dia eu falei assim: "Meu Deus, eu não posso perder isso, eu não posso jogar fora, o que é que eu vou fazer?"

Dona Rita

Tudo começou em 1985, quando o Sr. De Carlo Filho foi Festeiro. Naquela época, fazia-se a novena do Divino, em que uma imagem da Pomba Branca pernoitava nas casas de devotos, dias antes do início da Festa. Na ocasião rezava-se o terço, e quem quisesse e pudesse, contribuía para a Festa doando alguma quantia em dinheiro. De Carlo Filho convidou Dona Rita, que já era voluntária no café da Alvorada desde 1969, para auxiliá-lo na novena, visto que o número de pedidos de devotos querendo participar, foi aumentando, o que veio, mais tarde, a aumentar também o número de Rezadeiras.

Os pedidos feitos pelos devotos ao Espírito Santo eram dados, sem qualquer formalidade, a Dona Rita, para que ela os colocasse no altar, ao pé da Pomba do Divino, durante a missa de Pentecostes. Para não perder os pedidos, as Rezadeiras ${ }^{109}$, que hoje somam cerca de sessenta, levam duas caixinhas consigo: uma como "cofrinho" para os donativos, e outra para os pedidos ao Divino. Elas figuram como mensageiras do Espírito Santo, portando medalhas que as identificam como Rezadeiras e, desta forma, são consideradas, tanto pela Pró-Divino quanto pela igreja, como evangelizadoras.

A Missa do Envio marca o início dos trabalhos das Rezadeiras nas casas, cerca de quatro meses antes da Festa. Em 2006, o Bispo Dom Airton, durante a referida celebração, as orientou que levassem sempre consigo a Bíblia, instruindo-as a fazer a leitura de Salmos e de Atos dos Apóstolos durante as visitas aos devotos do Espírito Santo.

${ }^{108}$ Com base nas entrevistas realizadas com Dona Rita e Dona Albertina, ambas Rezadeiras do Divino.

109 Conforme ohservado durante as Festas do Divino de Mooi há anenas um homem no oruno pdfMachine

A pdf writer that produces quality PDF files with ease!

Produce quality PDF files in seconds and preserve the integrity of your original documents. Compatible across nearly all Windows platforms, simply open the document you want to convert, click "print", select the "Broadgun pdfMachine printer" and that's it! Get yours now! 
Assim, elas se organizam, agendando os pedidos das pessoas que querem ser visitadas pelo Divino, cada qual no seu bairro. Dona Albertina, por exemplo, como mora na Serra de Itapeti, peregrina pela área rural seguindo as orientações do Bispo, com sua medalha presa a uma fita vermelha, pendurada no pescoço. Dona Albertina não mede esforços para chegar, de charrete ou a cavalo, à casa daqueles que solicitaram sua presença. Seu empenho é, para os devotos do Divino que muito a respeitam, uma demonstração de fé.

Dona Rita descreve sua função ao chegar à casa do devoto: distribui um folheto com as orações e as músicas (Anexo C). Cantam e rezam a Coroa do Divino. Ao terminar a Coroa, Dona Rita lê um trecho da Bíblia e o comenta. Faz, a seguir, as três invocações de Nossa Senhora, conforme o folheto com a Coroa do Divino, e finaliza pedindo, ao Divino Espírito Santo, que abençoe os Festeiros e Capitães de Mastro, os encarcerados, as crianças, os jovens e os idosos, os internados e os enfermos, os governantes e o poder público, etc. Os donos das casas oferecem café, bolo, lanche... como manda a etiqueta e a tradição.

Na Procissão de Pentecostes, as Rezadeiras participam uniformizadas com saia e blazer azuis, levando as caixinhas com os pedidos ao Espírito Santo. Desse modo, ganham notoriedade. No Final da Festa, todos os pedidos colhidos pelas Rezadeiras são incinerados com incenso, em frente ao Império do Divino, montado na Praça da Catedral (Praça Coronel Almeida).

Quem pode abrir é só o Divino, ele é que sabe o que está ali dentro. Nós pegamos assim, mas ninguém pode estar lá abrindo. [...] Isso é sagrado, Ele que vai saber o que merece, o que não merece, o quê que pediu... Ele sabe em quanto tempo que [a pessoa] vai receber a graça. Não pode: "Eu ponho agora e já no outro mês recebo [a graça]". Não é. Ele é que sabe. [...] É coisa muito séria, muito sublime isso que nós fazemos aqui, essa caminhada. (D. Rita).

De uma prática espontânea com raízes no Bandeireiro (personagem da Festa que não existe mais) que saía pelas casas de devotos levando a Bandeira do Divino e angariando alguma prenda, as Rezadeiras atuam, hoje, de forma organizada, subordinadas à Associação Pró-Divino. Hoje, só pode atuar como Rezadeira aquela que tiver o cadastro junto à Associação, que mantém o controle do número de voluntárias, de bairros cobertos por elas, enfim, que administra a sua participação. Além disso, algumas Rezadeiras participam da organização do Café da Alvorada, da elaboração de doces e salgados vendidos durante a Quermesse, etc. 


\subsection{Iniciam-se as festividades do Divino}

Minha mãe tinha o costume de cobrir a nossa cabeça com a bandeira do

Divino, que era pra gente ficar inteligente.

Ana

A Festa tem início em uma quinta-feira, no dia da Ascensão de Jesus e da promessa da vinda do Espírito Santo sobre a Terra, que se dá justamente 40 dias após a Páscoa. $\mathrm{O}$ ponto de encontro é sempre em frente à residência dos Festeiros, portanto, localização diferente a cada ano. De lá, o devotos, portando, cada um, a Bandeira do Divino, seguem em procissão para o Império do Divino, montado e ainda não inaugurado, na Praça Coronel Almeida, conhecida também como Praça da Catedral.

As bandeiras do Divino têm significado importante na Festa, pois além de representar as formas de manifestação do Espírito Santo na Terra (o fogo, que é representado pela cor vermelha, e a pomba branca), são portadoras dos sete dons atribuídos ao Espírito Santo por Isaías $(11,2)$, no Antigo Testamento da Bíblia Sagrada, conforme já mencionado.

Não se sabe como, desde quando e nem o porquê da atribuição das cores aos dons, conforme segue: azul - sabedoria; prata - entendimento ou inteligência; verde - conselho; vermelho - fortaleza; amarelo - ciência ou conhecimento; azul escuro - piedade; roxo temor a Deus. Muitos devotos atribuem as cores aos dons sem seguir essa ordem oficial, "seguindo o que o coração mandar, assim cada cor de fita terá um dom diferente, e as fitas terão significados diferentes para cada devoto "110.

Sobre a atribuição das cores aos dons do Divino, há quem arrisque uma explicação, como faz Dona Terezinha ${ }^{111}$ :

Quando as línguas de fogo apareceram sobre eles [os discípulos de Jesus], parte do fogo resplandecia as cores como se fosse um arco íris. [...] Você

${ }^{110}$ Conforme relatos de participantes da Festa do Divino em Mogi das Cruzes no ano de 2003.

111 Fm entrevista realizada 
pode ver que as cores que vêm na Festa do Divino são as mesmas cores que existem no arco íris. [...] [O arco íris] é a aliança de Deus com a Terra.

Nada pode ficar sem explicação, pois cada momento, cada objeto, cada gesto parece ter um significado, conhecido por poucos devotos, os mais familiarizados com o ritual.

As fitas coloridas, penduradas às Bandeiras do Divino, além de representarem os dons, são marcadas com nós, pelos devotos. Esse gesto indica um pedido ou agradecimento por alguma graça alcançada. As fitas são incineradas no final da Festa, junto com os pedidos feitos por escrito e depositados em uma urna no interior do Império, e com os que estavam sob a guarda das Rezadeiras. A fumaça, acredita-se, ascenderá ao Espírito Santo os pedidos dos devotos.

E assim, as bandeiras estão nas Procissões, Passeatas e Missas durante os dias festivos, a partir da cerimônia de benzimento e Abertura do Império do Divino, na Praça da Catedral. Ali acontece o hasteamento de três bandeiras: a da Festa, ou seja, do Divino Espírito Santo, pelo Festeiro; a do município de Mogi das Cruzes, pelo Prefeito Municipal; e a da Paz ${ }^{112}$, pelo Bispo Diocesano, que benze as bandeiras do Divino, portadas pelos devotos juntamente com as dos novos Festeiros e Capitães de Mastro (Foto 12). O Prefeito ou um representante seu, presente na solenidade, é o Patrono da Bandeira e, pelo menos até a década de 1970 anunciava o início da Festa. (MORLINI; KATO, 1973). Hoje é o Festeiro quem faz uso da palavra, oficializando a Festa.

A abertura do Império do Divino acontece sob o som da Folia do Divino ${ }^{113}$, que toca e canta:

${ }^{112}$ Com o objetivo de cultuar a paz, a bandeira branca foi introdução na Festa do Divino a partir de 2001, sob influência de Toninho Macedo, então Coordenador de Folclore da Secretaria de Estado da Cultura (O DIÁRIO DE MOGI, 25/05/2001), e organizador do Revelando São Paulo, evento que acontece anualmente em setembro, no Parque da Água Branca e tem o intuito de valorizar e divulgar a cultura tradicional paulista. Neste ínterim, resolveu-se hastear também a bandeira do município de Mogi das Cruzes, conforme entrevista realizada com o Sr. Jurandyr.

Cabe mencionar que a bandeira branca levada por Toninho Macedo naquele ano pertence ao Comitê Paulista Uma Década de Cultura pela Paz, e já foi hasteada em vários estados brasileiros, como também em vários países. (O DIÁRIO DE MOGI, 25/05/2001).

113 Anresentaremos a Folia do Divino bon a seowir 
Império tão bonito

Muito bem preparado

Onde está o Divino Espírito Santo

No seu trono adorado.

A cada ano o Império do Divino Espírito Santo é montado quando começa, e desmontado quando termina a Festa; é, portanto, uma construção temporária que abriga o altar da Pomba Branca (símbolo do Espírito Santo), o Cetro e a Coroa (símbolos da realeza), durante os dias festivos (Fotos 15-18). A Festeira, em todas as procissões leva consigo a Coroa sobre a bandeja, ao passo que a Capitã do Mastro leva o Cetro. Ao Festeiro e ao Capitão do Mastro, cabem carregar, cada um a sua bandeira.

A ornamentação é diferente em cada Festa. Sempre com muito bom gosto, capricho e requinte, é feita sob a coordenação da Associação Pró-Divino. O Império tem sido decorado, já há algum tempo, pelo artista plástico Sérgio Vicco, juntamente com Salete, uma das coordenadoras da Associação Pró-Divino. Sob sua responsabilidade estão todas as ornamentações da Festa, que incluem ainda o interior da Catedral de Santana, o andor do Divino que sai em procissão no Domingo de Pentecostes, e os anjos que o acompanham. 
Foto 12.

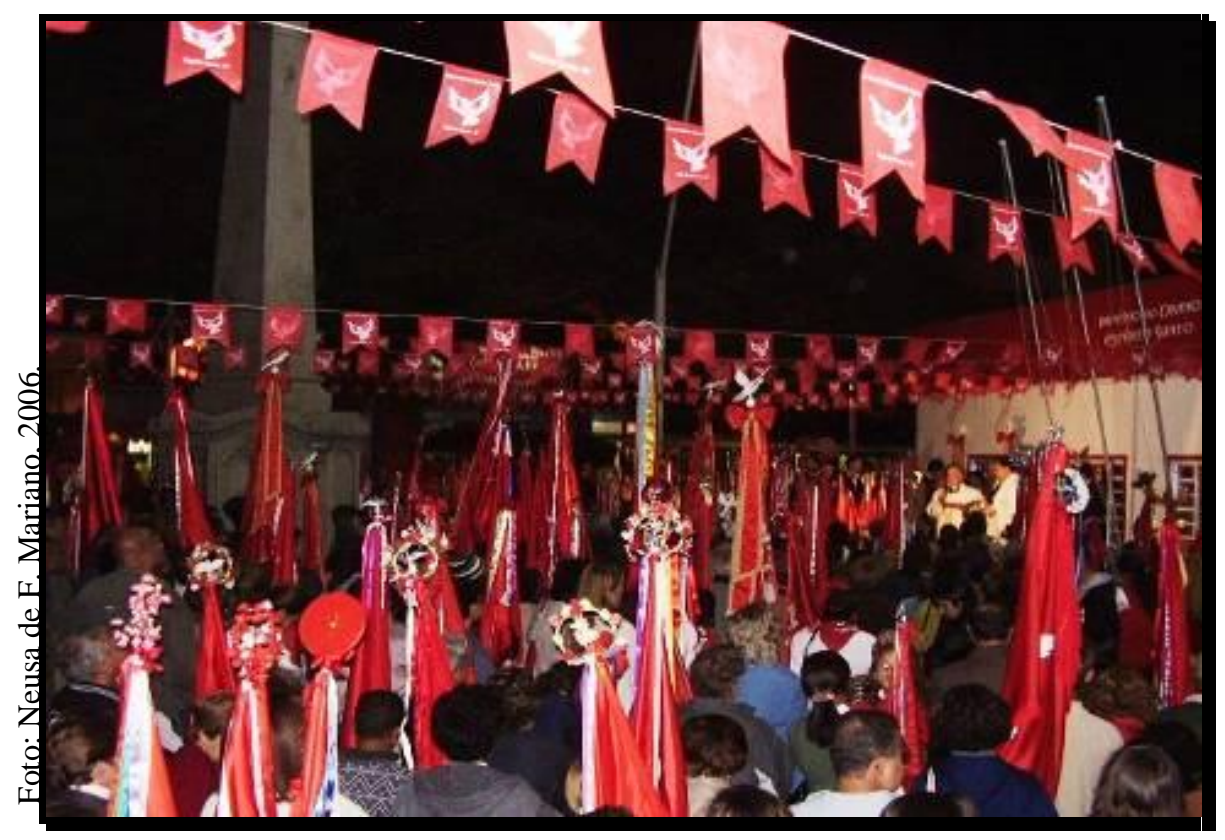

O primeiro ato da festa é a abertura do Império. Quando abre o Império, chegam os festeiros com as bandeiras e estacionam defronte ao Império...

Jurandyr

Foto 13.

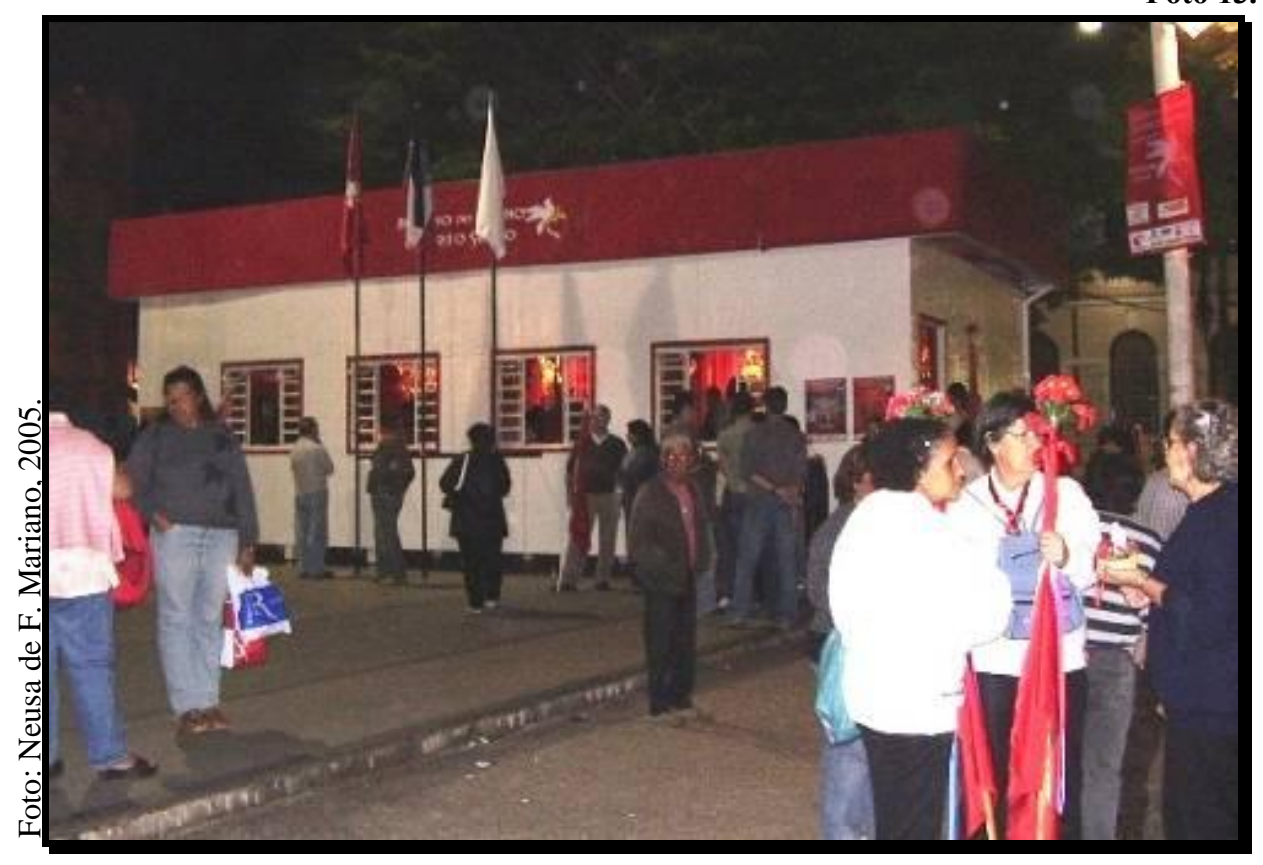

Mas eu já não podia mais andar com aquela bandeira porque ela era muito grande, muito pesada. Eu saía com ela e achava bonito, aquela bandeira que ia quase que até o chão...

Georgina

\section{pdfMachine}

\section{A pdf writer that produces quality PDF files with ease!}

Produce quality PDF files in seconds and preserve the integrity of your original documents. Compatible across

nearly all Windows platforms, simply open the document you want to convert, click "print", select the

"Broadgun pdfMachine printer" and that's it! Get yours now! 
A decoração do altar do Divino, representado pela Pomba Branca, muda a cada ano.

Foto 14

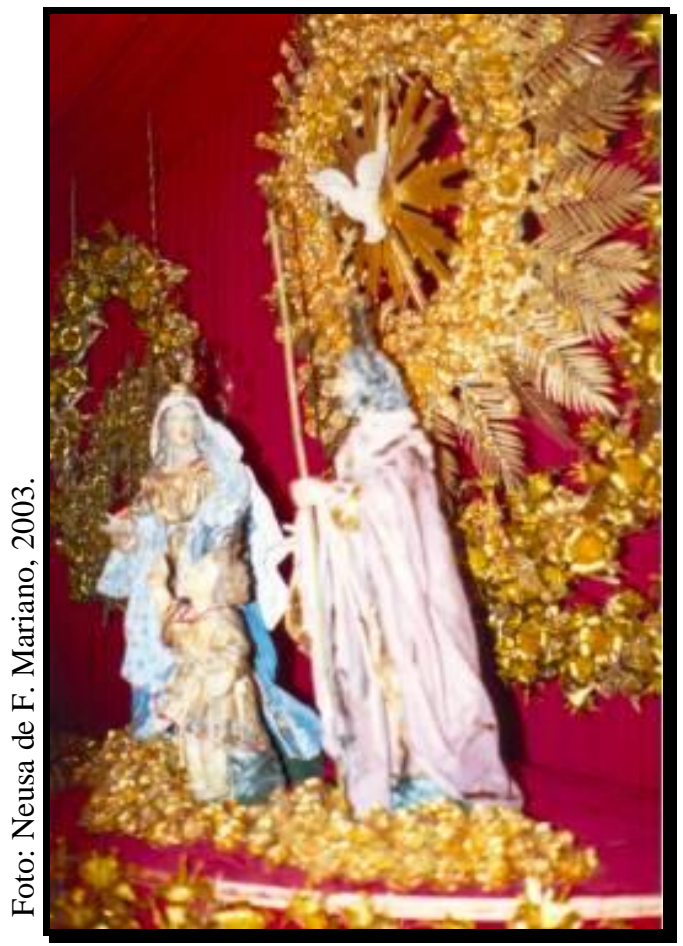

Foto 15.

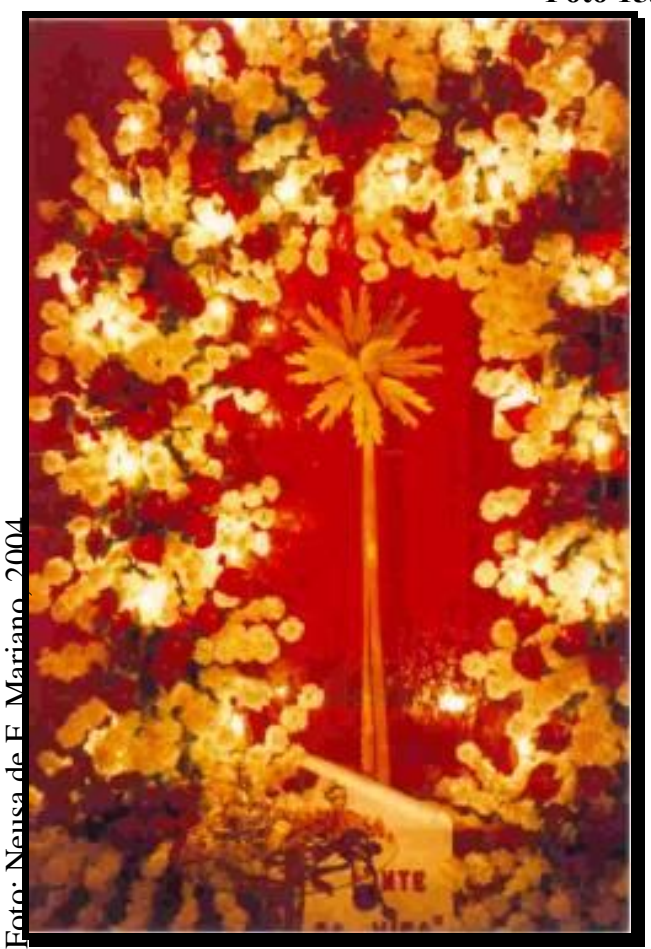

O império normalmente é ornamentado com flores artificiais, porque senão a gente tem que ficar trocando e não dá!

Foto 16

Salete

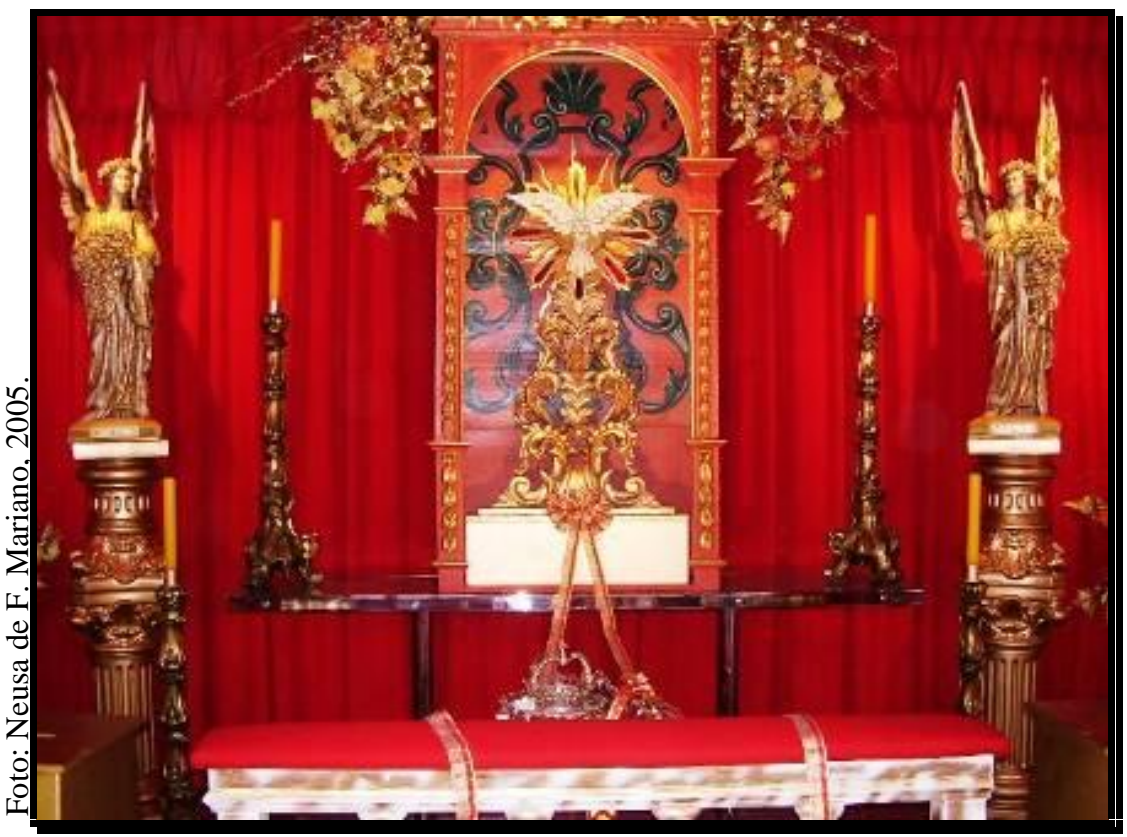

pdfMachine

A pdf writer that produces quality PDF files with ease!

Produce quality PDF files in seconds and preserve the integrity of your original documents. Compatible across nearly all Windows platforms, simply open the document you want to convert, click "print", select the "Broadgun pdfMachine printer" and that's it! Get yours now! 
O Divino Espírito Santo é uma energia de Deus, quem representa ela é uma ave, que voa, pomba branca, a natureza. Então é assim, é uma energia que você sente de Deus através da pombinha. Então você se concentra, você fecha os olhos e se concentra e você sente Deus.

Roberto

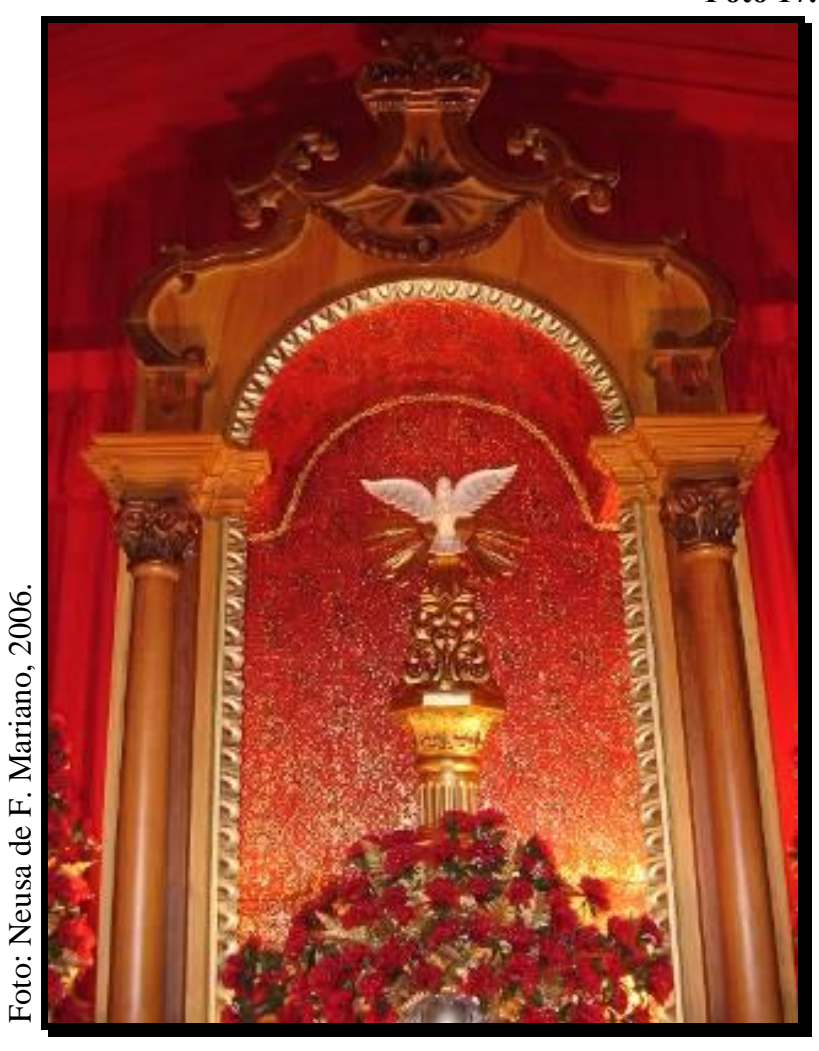

Foto 18.

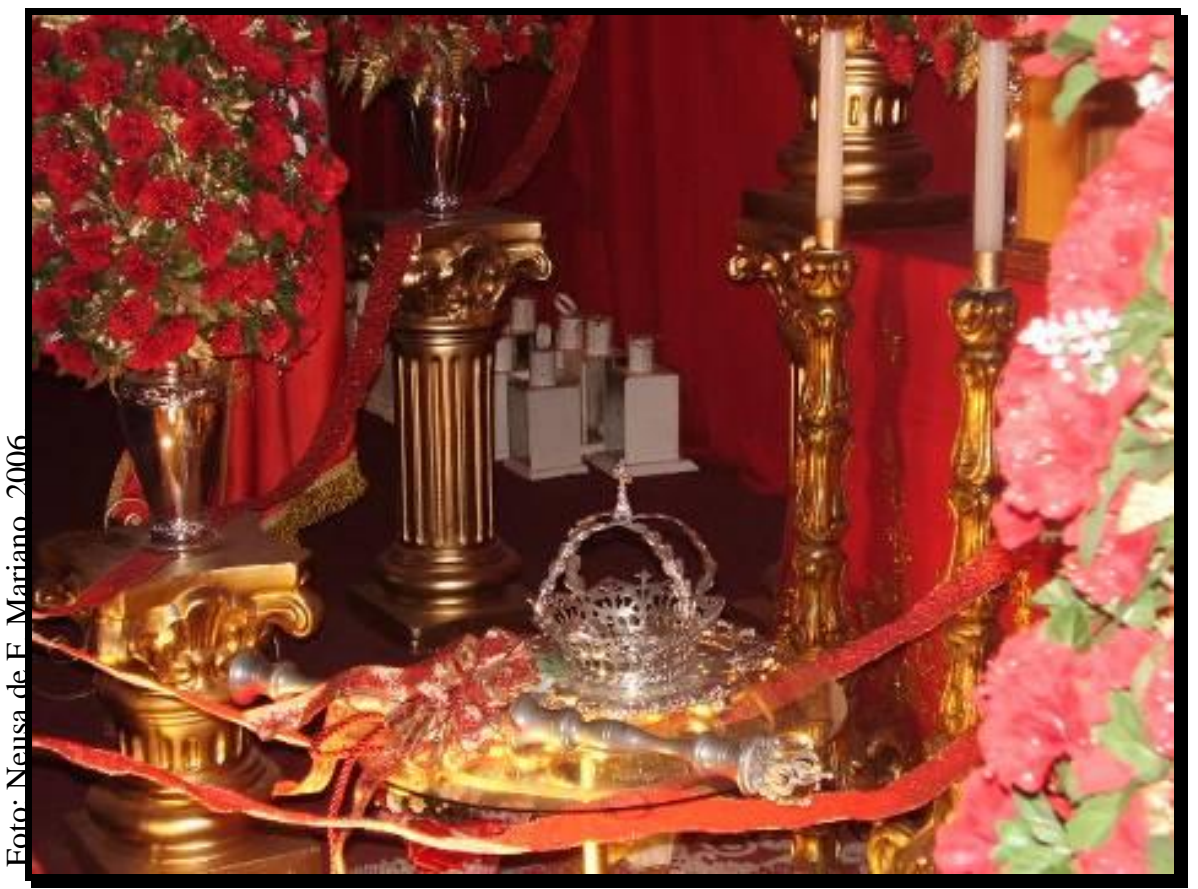

Cetro e Coroa no Império do Divino. Ao fundo as lanternas usadas nas Alvoradas e nas Passeatas das Bandeiras.

\section{pdfMachine}

\section{A pdf writer that produces quality PDF files with ease!}

Produce quality PDF files in seconds and preserve the integrity of your original documents. Compatible across nearly all Windows platforms, simply open the document you want to convert, click "print", select the "Broadgun pdfMachine printer" and that's it! Get yours now! 


\subsubsection{Do religioso e do folclórico}

Nos primórdios da Festa do Divino em Mogi das Cruzes (início do século XIX), o profano e o religioso discerniam-se mal, pois tudo o que poderia ser considerado profano tinha sido incorporado pela Igreja, como integrante da religiosidade: Quermesse, grupos de Congada e Moçambique, Bandeireiro, etc. A Festa era centralizada na Igreja, que era a centralidade da vida das pessoas.

A divisão da Festa do Divino em profana e religiosa, introduzida com a Romanização acentua-se, no Brasil, com o advento da República (final do século XIX), e vai sendo cada vez mais nítida diante do contexto urbano industrial que se instalava a partir do final do século XIX na cidade de São Paulo e que se expandia aos municípios vizinhos.

Com a expansão da cafeicultura e o início da industrialização, profundas transformações passaram a ocorrer na economia e na sociedade brasileiras. Dentre os desdobramentos destas novas atividades econômicas, a cidade de São Paulo e inúmeras cidades paulistas entraram em fase de rápido crescimento já no final do século XIX. A dissolução crescente do modo de vida rural, à medida em que avança o processo de urbanização, enfraquece a centralidade da Igreja.

A racionalidade começava a se insinuar na festa popular de caráter tradicional religioso em Mogi das Cruzes que, aos poucos foi separando o que pode ser considerado religioso e folclórico. (Como mostra a Programação da Festa de 2006, no Anexo D).

À parte religiosa pertencem a Abertura da Festa com a inauguração do Império do Divino e a bênção de novas bandeiras, a Novena, a Procissão de Pentecostes, a incineração dos pedidos ao Espírito Santo e o fechamento do Império. Ao folclore pertencem a Passeata das Bandeiras, a Alvorada, a Missa no cemitério ${ }^{114}$, os Folguedos Infantis, a Entrada dos Palmitos e o levantamento do Mastro. Apresentaremos, a seguir, cada um dos momentos da Festa do Divino Espírito Santo de Mogi das Cruzes, organizada atualmente com o auxílio da Associação Pró-Festa do Divino.

${ }^{114}$ Talvez por fazer parte da Alvorada, a Missa no Cemitério esteja na parte folclórica, conforme a Prooramacão da Festa do Divino de 2006 


\subsubsection{Novena}

O que eu gosto, o que me toca mesmo, são as celebrações, porque lota, são pessoas de tudo quanto é lugar, e cada celebrante tem uma mensagem

diferente pra você...

Elisete

A Novena da Festa do Divino consiste em nove missas, com a participação de várias paróquias da Diocese de Mogi das Cruzes ${ }^{115}$, todas celebradas na Catedral de Santana (Fotos 19 e 20). A Novena começa no segundo dia da Festa (na sexta-feira), às 19:00h, sendo a primeira missa celebrada pelo Bispo Diocesano de Mogi das Cruzes.

A Catedral sempre esteve muito bem decorada, durante as festividades do Divino Espírito Santo, com flores douradas e prateadas, muitas vezes reaproveitadas do ano anterior $^{116}$. Segundo relatos, o Bispo Dom Airton que está em Mogi das Cruzes há dois anos, solicitou esforços por parte dos organizadores da Festa para a promoção da simplicidade, o que se constatou, na Festa de 2006, também na decoração da igreja de Santana, ornamentada com flores naturais em arranjos singelos.

Os Padrinhos ${ }^{117}$, que somam cerca de cinquenta casais, ocupam os bancos reservados a eles, na frente do altar da igreja, onde também ficam os Festeiros e Capitães de Mastro. Os casais de Padrinhos entram na Catedral em fila já organizada na Praça, em frente ao Império, nos últimos minutos que precedem o início da missa.

Algumas das missas são celebradas, por vezes, por três padres, de Paróquias

${ }^{115}$ As missas da Novena que, até 1979, eram celebradas cada dia em paróquia diferente, passaram a se concentrar na Catedral de Santana. Porém diferentes paróquias são convidadas a celebrá-las $(\mathrm{O}$ DIÁRIO DE MOGI, 10/05/1979).

${ }^{116}$ Conforme entrevista com Salete.

${ }^{117}$ O convite para ser Padrinho, feito pelo casal de Festeiros, segue junto a um envelope para doação de qualquer quantia em dinheiro com o intuito de ajudar nas despesas da Festa, conforme entrevista realizada com o Sr. Mathias, responsável pelo Tapete Ornamental sobre o qual trataremos mais adiante 
diferentes. No ano de 2006, no primeiro sábado da Festa (segundo dia da Novena), a missa teve como celebrantes os padres das Paróquias de Nossa Senhora Aparecida - do município de Santa Isabel (Pastoral Afro), de São Benedito - do distrito de Biritiba Mirim-, e de Nossa Senhora do Socorro - de Mogi das Cruzes. Participaram ainda da Novena as Paróquias do Carmo e da Comunidade de Santa Terezinha, de São Benedito e São Pedro - todas de Mogi das Cruzes - além da Paróquia Nossa Senhora de Lourdes do município vizinho de Poá.

Missa muito concorrida e comentada tem sido a celebrada pela Pastoral Afro, que ganhou destaque nos jornais locais, por ser diferente, colorida, alegre e, por isso, atraindo muita gente, lotando a Catedral de Santana. A Pastoral Afro tem sido convidada a participar das festividades do Divino desde $2003^{118}$, e reúne em suas missas, alimentos colocados em cestas (frutas, verduras, pães, pipoca...) e instrumentos musicais de origem africana (atabaques, bangôs e berimbaus). Em momentos específicos da celebração, como no Ofertório, fiéis desfilam pela nave central da igreja vestidos com abadás, levando ao altar os alimentos.

A Catedral de Santana, sempre lotada, demonstra que a Novena funciona também como forma de divulgação da Festa do Divino, já que os devotos de diversas Paróquias de Mogi e região têm oportunidade de tomar maior contato com ela, através, por exemplo, da visita ao Império do Divino.

A Festa também reserva um espaço religioso para abrigar outras crenças. Trata-se de um Culto Ecumênico pela Unidade dos Cristãos, com a presença de várias Igrejas Cristãs. Realizada no primeiro sábado da Festa à tarde, esta celebração não faz parte, entretanto, da Novena.

118 Pelo menos, a primeira notícia encontrada sobre a Missa Afro, durante a Festa do Divino, está reoistrada no Diário de Mnoi $06 / 06 / 2003$ 
Foto 19.

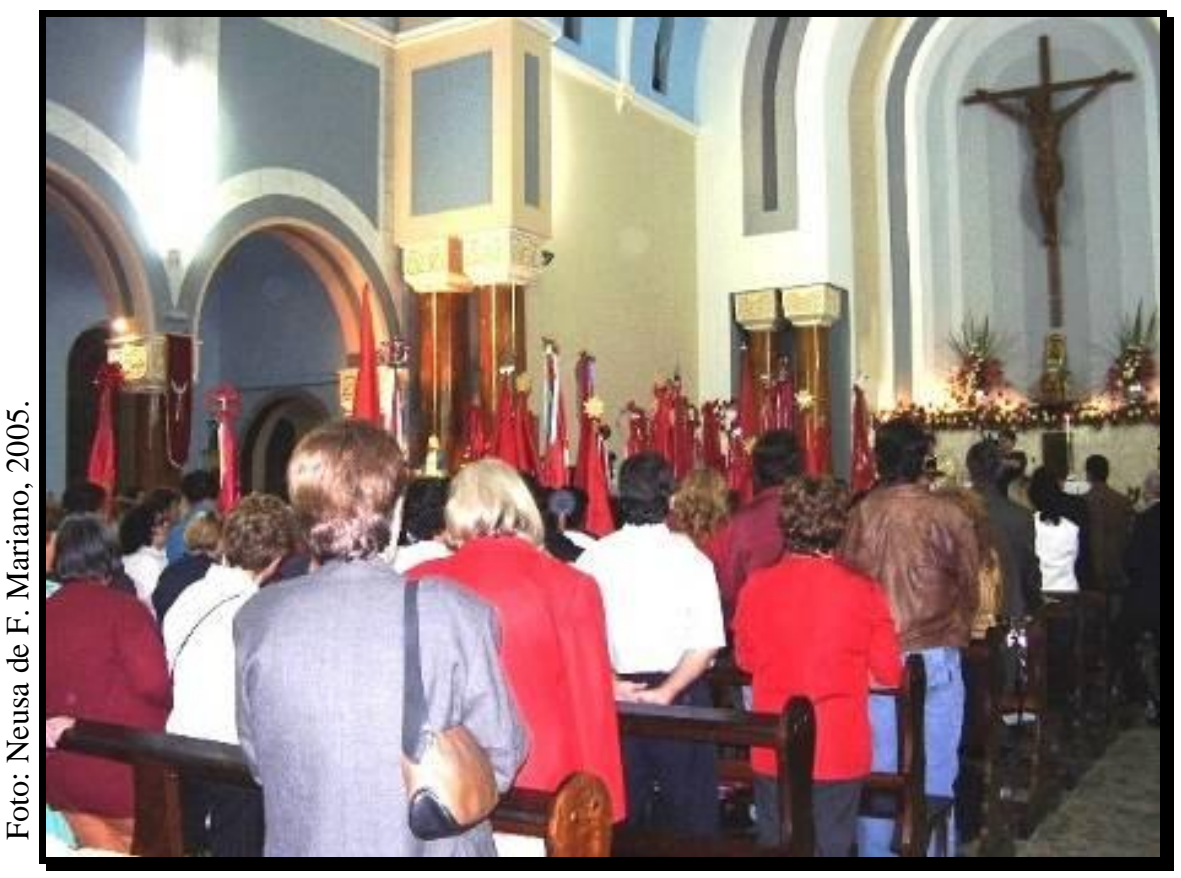

Nas duas últimas festas do Divino ele [o Bispo] procurou focar essa parte religiosa [...]. Está sendo uma transformação muito positiva. As festas de Mogi, era muito cheia de ornamentos, existia até uma disputa, quem que ornamentava melhor a Igreja. E a orientação do nosso Bispo agora é assim: isso dai é um acessório que pode ser eliminado, contanto que você foque o gasto, o custo da festa, foque mais essa parte religiosa, dar mais conforto para as pessoas, ter um som melhor, ter mais cadeiras na igreja que possam acomodar todo mundo que queira participar.

Elisete

Foto 20.

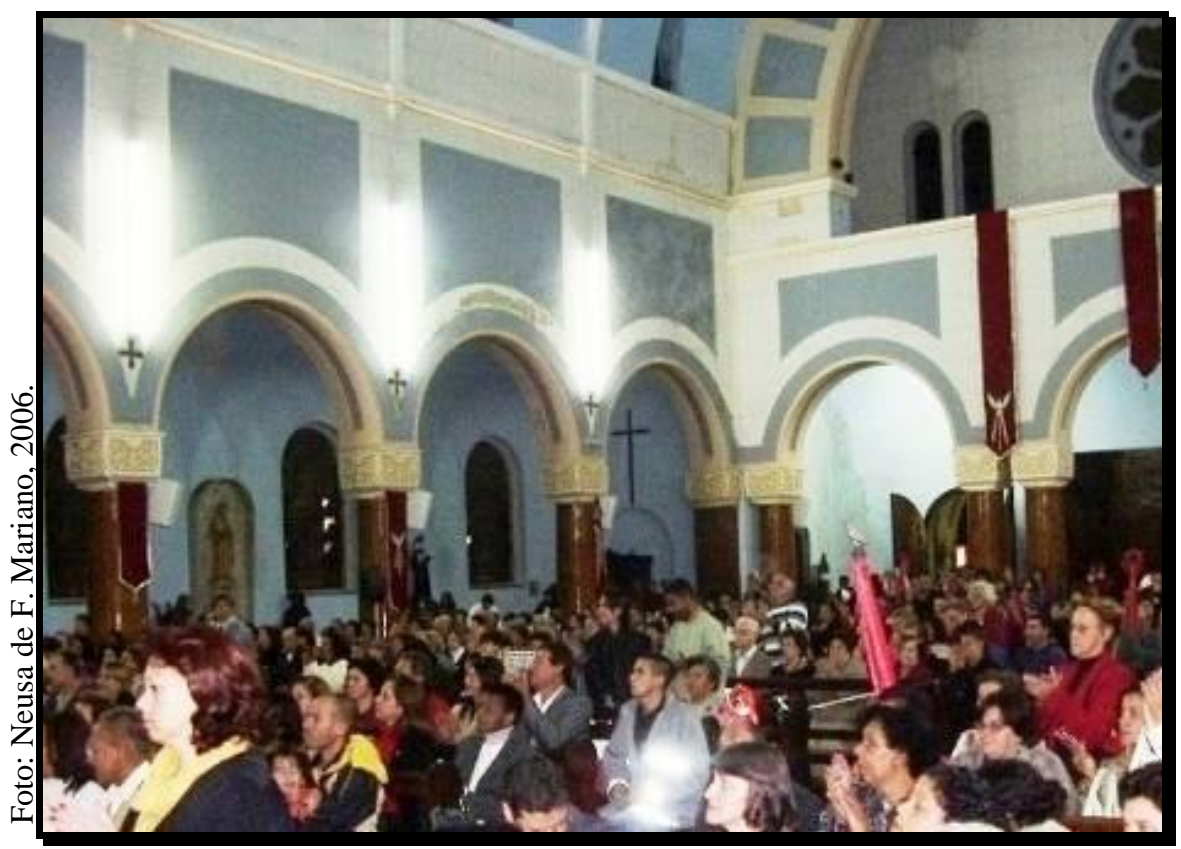

pdfMachine

A pdf writer that produces quality PDF files with ease!

Produce quality PDF files in seconds and preserve the integrity of your original documents. Compatible across nearly all Windows platforms, simply open the document you want to convert, click "print", select the "Broadgun pdfMachine printer" and that's it! Get yours now! 


\title{
5.3.3 A Folia do Divino na Passeata das Bandeiras e na Alvorada
}

\author{
Quando vir em sua casa \\ uma bandeira chegar \\ É o Divino Espírito Santo \\ que veio the visitar.
}

Sr. Ulisses, Mestre da Folia do Divino de Biritiba Ussu

Antes de trilharmos pela Passeata das Bandeiras e pela Alvorada, é preciso conhecer a Folia do Divino que atua nestes momentos. Dentro da totalidade do ritual religioso - a Festa do Divino - a Folia tem a função de levar o Espírito Santo às casas dos devotos, através da música caipira ${ }^{119}$, em que o canto é acompanhado por instrumentos de corda e de percussão.

A Folia do Divino de Biritiba Ussu ${ }^{120}$ está composta por cinco membros: o Mestre e violeiro é o Sr. Ulisses ${ }^{121}$, sitiante em Biritiba Ussu, onde moram também o Sr. Alcides, Contramestre e tocador de violão, e o Sr. Milton, tiple (voz mais aguda), que toca caixa. Roseli, que mora no centro de Mogi das Cruzes, também é tiple e toca pandeiro. A voz mais grave, ou contralto, é a do Sr. Salvador, que mora no distrito de Jundiapeba ${ }^{122}$ e que também

119 Conforme Martins (1975: 105, grifo do autor): “A música caipira nunca aparece só, enquanto música. Não apenas porque tem sempre acompanhamento vocal, mas porque é sempre acompanhamento de algum ritual de religião, de trabalho ou de lazer". Alguns de seus componentes como, por exemplo, o cururu, o cateretê, o recortado, a congada, foram reduzidos à condição de "batida" ou "andamento", ao serem introduzidos na música sertaneja. Esta, voltada para o mercado fonográfico, não integra os rituais, é só música. É bom observar que a música sertaneja a qual se refere Martins é aquela atualmente conhecida como "música raiz" ou "música caipira de raiz".

${ }^{120}$ Não foi encontrada outra Folia do Divino em Mogi das Cruzes, somente a de Biritiba Ussu, que leva o nome do distrito de origem. A Folia viaja (quando convidada) pelos demais distritos de Mogi das Cruzes e região, onde também são realizadas Festas do Divino.

${ }^{121} \mathrm{O}$ Sr. Ulisses começou a cantar e tocar na Folia de Biritiba Ussu aos 24 anos de idade. Hoje, aos 67 anos, soma 43 de Folia do Divino.

122 Assim a Folia não é formada exclusivamente nor moradores do distrito de Biritiha Uscu pdfMachine A pdf writer that produces quality PDF files with ease!

Produce quality PDF files in seconds and preserve the integrity of your original documents. Compatible across nearly all Windows platforms, simply open the document you want to convert, click "print", select the "Broadgun pdfMachine printer" and that's it! Get yours now! 
toca pandeiro.

Para entrar no grupo da Folia do Divino é preciso possuir um instrumento (viola, violão, pandeiro, caixa...) e saber tocar, ter aptidão para o canto, e participar dos ensaios, realizados quando necessário. O papel do Mestre é estar sempre à frente, "puxando" a música para que o restante do grupo o acompanhe; é ele quem dá o comando, escolhendo os versos a serem cantados ${ }^{123}$.

Pelos cálculos do Sr. Ulisses, os cerca de sessenta e sete versos escritos que o seu padrinho recebeu do pai e que agora estão em suas mãos, somam mais ou menos cem anos; versos esses que, segundo o Mestre da Folia, não podem ser mudados, razão pela qual são cantados tais quais lhe foram transmitidos. Primeiramente, a Folia do Divino costumava arrecadar donativos somente para as Festas do Divino de Biritiba Ussu, o que permaneceu até por volta de 1970. Nos momentos pré-Festa, levava a bandeira do Divino e a passava por todos os cômodos das casas, localizadas em bairros rurais de Mogi das Cruzes:

Nós, antigamente, cantávamos de dia, era o dia inteiro. Por exemplo, nós chegávamos nessa casa aqui, ali pelas cinco horas [da tarde]. Pedia o pouso, para mim e para todos que vinham comigo. [...] Jantava aqui e pousava. No outro dia, nós saíamos a cantar em volta, assim, numas cinco, dez casas. Daí vinha, almoçava, agradecia tudo e já ia para a outra casa. [...] Naquele tempo era tranqüilo, parece que ninguém tinha tanto compromisso como agora. Agora é muito compromisso. Então a gente saía trinta dias, tirar dinheiro para a Festa... E a turma dava tanta coisa, dava pouso... Até porco a turma dava! Eles davam, a gente agradecia. Depois, no dia da Festa eles levavam. Dinheiro nós levávamos. [...] De noite, na casa em que a gente pousava, chegava na mesa, assim, e colocava o dinheiro, contava tudo, quanto dava. Daí, no outro, de novo. Ajudava bem o dinheiro, dava... ajudava bem. Entregava para o Festeiro.

Segundo Martins (1975: 108), o ciclo do cotidiano do caipira é marcado pelo da natureza (estações do ano) e o das comemorações litúrgicas do catolicismo, harmonizando os dois calendários. Assim, a Folia do Divino sai em peregrinação pelos bairros rurais arrecadando prendas para a Festa, após a colheita e antes do preparo da terra para novo plantio. Neste período, os donativos estão disponíveis, oferecendo à Festa, a abundância de alimentos, principalmente em carnes. Ao mesmo tempo, as prendas para a Festa do Divino garantiriam ao sitiante, prosperidade no novo plantio.

Lefebvre (1958) contribui para a reflexão quando se refere à festa da antiguidade. Para este autor, a recusa em contribuir com donativos para a realização da festa, significaria 
correr o risco da escassez.

Na Festa do Divino de Mogi das Cruzes, a participação da Folia era e é reduzida, como ressalta o Sr. Ulisses: "Só que lá [em Mogi] nós não cantávamos de dia, nós cantávamos só essa passeata que sai nas casas, às noites, um pouquinho, e na rua".

Os donativos para a Festa eram conseguidos através do Livro de Ouro, em Mogi das Cruzes, na década de 1960, quando a Folia do Divino de Biritiba Ussu foi convidada a participar. A Folia se ocupava em angariar prendas para a Festa do Divino de Biritiba Ussu, e não poderia, portanto, dedicar-se da mesma forma às duas Festas que ocorriam na mesma época. Em Biritiba Ussu, a Folia logo sentiu o enfraquecimento da participação dos foliões em sua função. O problema estava relacionado ao trabalho. Os foliões que, até então, viviam a condição de camponeses, se viram obrigados a uma nova inserção no mundo do trabalho.

Com base nos estudos de Martins (1975) sobre a música sertaneja no contexto da cultura caipira, é possível dizer que os foliões do Divino de Biritiba Ussu, são personagens do processo de urbanização que provocou "[...] a perda da liberdade, isto é, do ajustamento ao ciclo da natureza para o ajustamento compulsório ao ciclo das obrigações formais, do relógio de ponto, etc., na indústria”. (MARTINS, 1975: 145).

Nesse ajustamento ao contexto urbano-industrial, houve a redução do ritual da Folia do Divino, que perdeu, não só a função de recolher donativos nos bairros rurais, como a de conduzir a bandeira do Divino pelos bairros rurais. Os foliões começaram a atuar somente durante o tempo livre do grupo, e a sua participação se limita hoje, tanto na Festa de Mogi das Cruzes como na de Biritiba Ussu, à Passeata das Bandeiras e à Alvorada ${ }^{124}$. Assim, caíram em desuso os versos que se cantava pedindo e agradecendo pousos nos sítios para a Festa do Divino de Biritiba Ussu. Os versos cantados pela Folia fazem referência ao que está acontecendo no momento, de conformidade com o ambiente (se há velas acesas, imagens de Nossa Senhora e de santos no Subimpério (Foto 21), se os anfitriões oferecem bebidas alcoólicas aos participantes da Passeata das Bandeiras, se há alguém enfermo na casa, etc.):

${ }^{123}$ Conforme entrevista com Sr. Ulisses. 


\begin{abstract}
Abençoada foi a mão
que acendeu aquela vela

Será abençoado

por essa bandeira donzela.

As imagens que aqui estão

E todas elas são sagradas

Em nós lançai a santa benção

Por a grande caridade.
\end{abstract}

A Passeata das Bandeiras acontece por nove noites, a partir de sexta-feira até o sábado, véspera de Pentecostes (sempre após a Missa da Novena). Parte da Praça da Catedral, onde está o Império do Divino e geralmente segue para a residência de alguma família previamente agendada pelos organizadores da Festa (leia-se Associação Pró-Divino e Festeiros).

Durante o trajeto $^{125}$, devotos com suas bandeiras em punho, acompanham os Festeiros e Capitães de Mastro, os Lanterneiros e a Folia do Divino (Foto 22). Cantam ao som dos instrumentos da Folia, cânticos em louvor ao Espírito Santo ${ }^{126}$ (Anexo C). No intervalo entre uma música ou oração e outra, dá-se VIVAS aos Festeiros, aos Capitães de Mastro, à Folia do Divino, aos voluntários, enfim aos devotos em geral. Estas visitas são, na verdade, aberturas de Subimpérios que, aliás, ocorrem também antes da Festa, realizadas pelos Festeiros e Capitães de Mastro, sem a participação da Folia do Divino.

Ao chegar no destino (geralmente casa de ex-Festeiro), os Festeiros e Capitães de Mastro passam aos donos da casa o cetro, a coroa e a bandeira do Divino que irá abençoar a família. A Folia do Divino toca e canta o verso de chegada (conforme epígrafe do capítulo) e, em frente ao Subimpério (Foto 23), o anfitrião faz uso da palavra ao agradecer a visita, e ao demonstrar a sua devoção. Aliás, devoção esta expressa pela casa, cenário decorado com

${ }^{124}$ Como a Passeata é noturna e a Alvorada, de madrugada, e Biritiba Ussu é distante do centro de Mogi das Cruzes, o grupo fica hospedado no Hotel São Gabriel (centro), uma oferta do proprietário, que já se estende por oito anos. Antes disso, a Folia pernoitava na Casa da Festa.

${ }^{125}$ Rapazes do Tiro de Guerra e a Guarda Municipal acompanham organizando o trânsito, tanto na Passeata como na Alvorada.

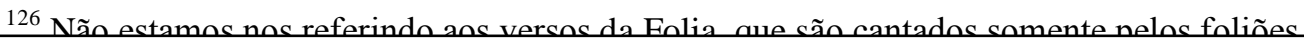
pdfMachine

A pdf writer that produces quality PDF files with ease!

Produce quality PDF files in seconds and preserve the integrity of your original documents. Compatible across nearly all Windows platforms, simply open the document you want to convert, click "print", select the "Broadgun pdfMachine printer" and that's it! Get yours now! 
motivos do Divino: quadros, pombas artesanais (em madeira, gesso, barro), bandeiras, lembrancinhas de festas anteriores, etc.

A emoção das pessoas, ao receber a Passeata das Bandeiras com a Folia do Divino, os Festeiros e Capitães de Mastro em suas casas, é bastante evidente através das palavras, dos olhares, das lágrimas, pois para elas, estão recebendo o próprio Espírito Santo.

Todos rezam, a Folia canta conforme o que se apresenta no ambiente e, ao término, são oferecidos a todos os presentes pães e bolos, chocolate quente, café ou chá... A Folia canta novamente, fechando o ritual em frente ao Subimpério, agradecendo e abençoando a família e todos seguem de volta para o Império do Divino. Geralmente é visitada uma família por noite, cujas residências localizam-se nas proximidades da Catedral de Santana (Mapa 5).

Ultimamente, porém, tem sido freqüente a passeata visitar empresas como o Jornal O Diário de $\operatorname{Mogi}^{127}$ (Foto 24), a TV Diário e a Universidade de Mogi das Cruzes, pois são pólos de divulgação e figuram como apoiadoras da Festa do Divino. A Universidade de Mogi das Cruzes localiza-se distante da Catedral, assim como a TV Diário, instalada no Distrito de César de Souza e, ir e voltar em passeata, demandaria muito tempo. Por isso, o percurso até estes dois locais, é feito de ônibus (geralmente dois), o que leva a modificar o ritual da caminhada que, de rezas e cantos pelas ruas da cidade, passa para conversas paralelas num espaço pequeno.

Assim como nas residências, o ambiente da recepção do jornal O Diário de Mogi, decorado com o tema da Festa do Divino, não é exclusivo do tempo festivo. Quadros na recepção do Jornal retratam a Folia do Divino, grupos de Congada e Moçambique e decoram o ambiente o ano todo.

Já em 1994, (é bom lembrar, quando foi fundada a Associação Pró-Divino) a Passeata das Bandeiras visitou a Universidade Mogi das Cruzes, quando foi recepcionada por Inezita Barroso (O DIÁRIO DE MOGI, 18/05/1994). Esboçava-se, naquele momento, a atuação pela integração dos jovens universitários na Festa do Divino, tanto na UMC, como na UBC.

${ }^{127}$ Uma funcionária do Diário de Mogi, contou em conversa rápida (agosto de 2006), que no início dos anos 2000, o Jornal estava passando por uma grave crise, correndo o risco de falência. Ela, como devota do Espírito Santo, sugeriu ao seu chefe que se fizesse um Subimpério do Divino, na recepção da empresa, e que ele pedisse a visita da Folia do Divino para abençoá-lo, durante a Passeata das 


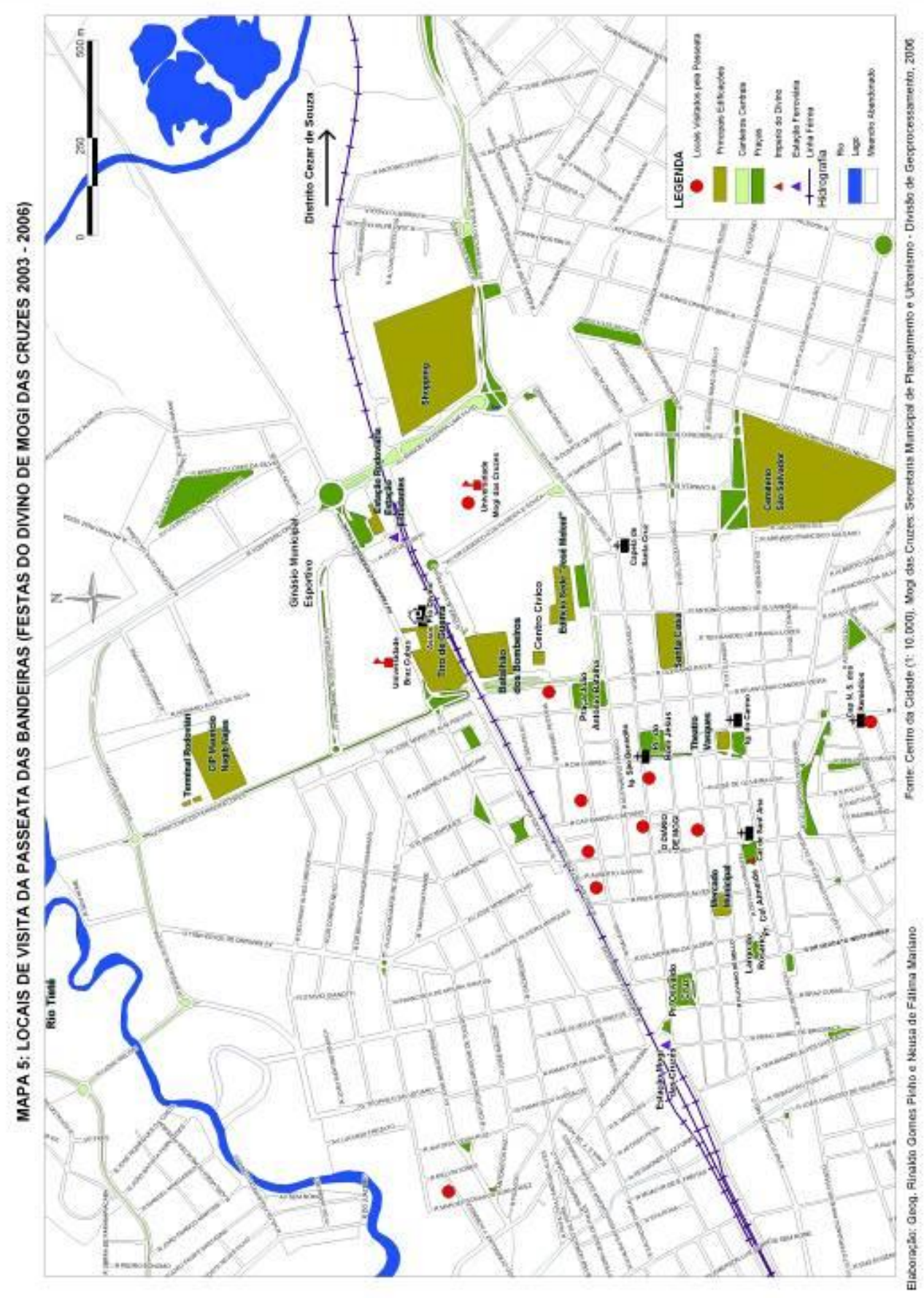

Bandeiras. Tal feito, como acredita a funcionária, "tirou o Jornal do sufoco" e, por isso, resolveu-se montar um Subimnério também na TV Diário emnreca nertencente an mesmo oruno 


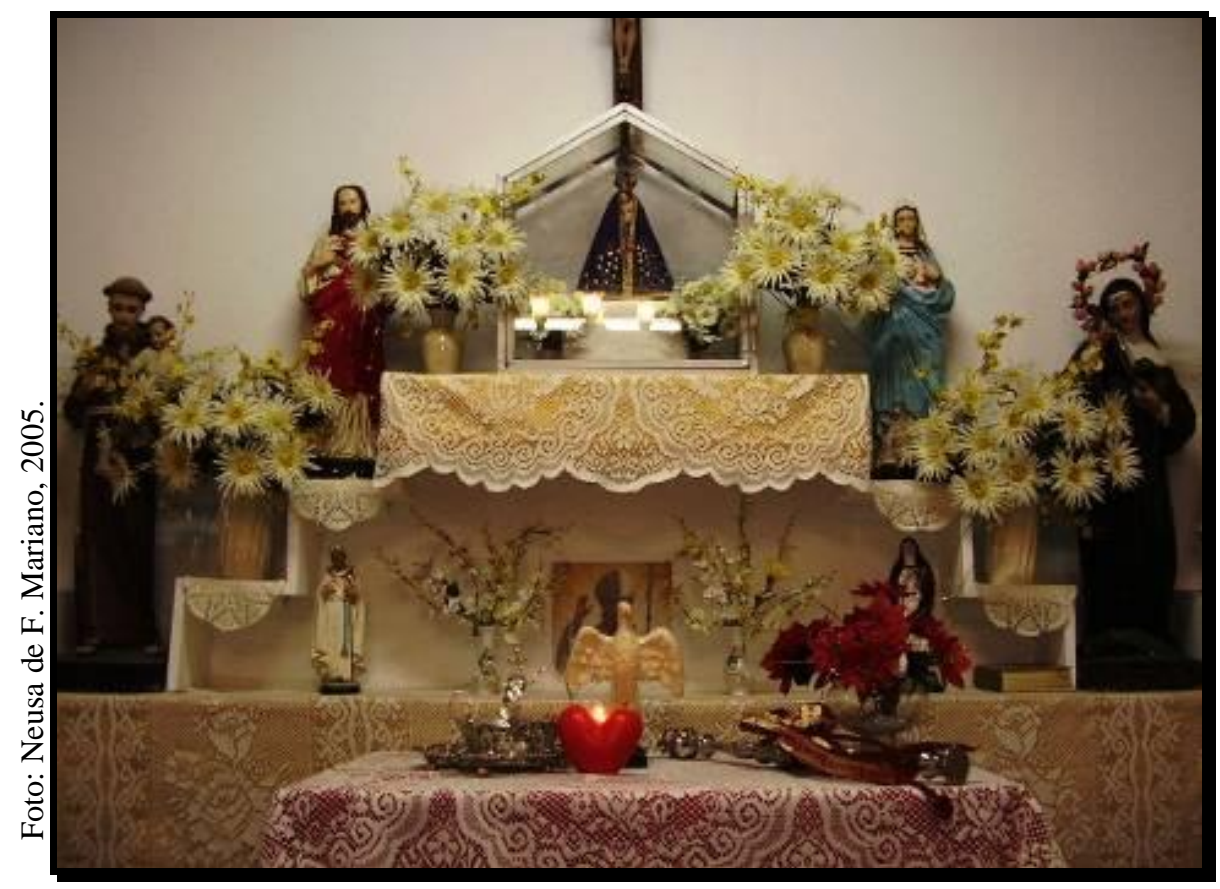

O Subimpério montado na Capela de Nossa Senhora dos Remédios recebeu a visita da Passeata das Bandeiras, com a Folia do Divino de Biritiba Ussu.

Foto 22.

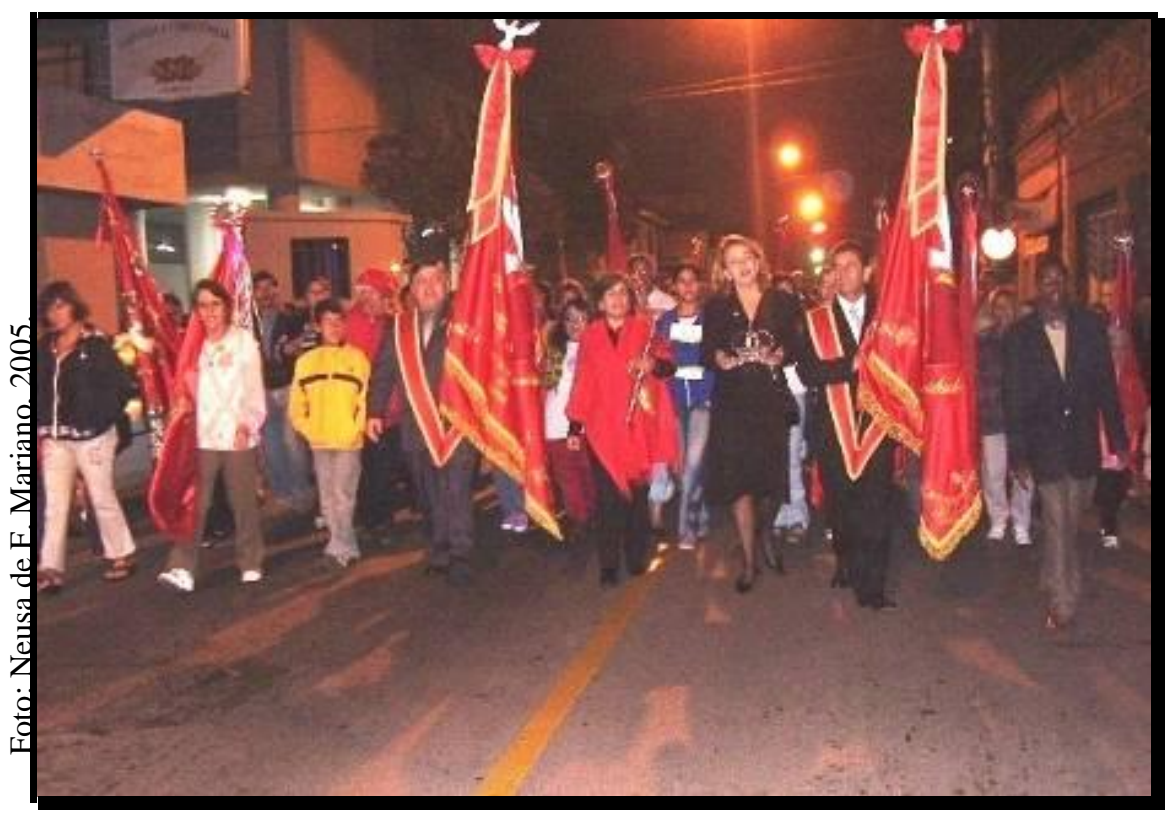

À frente da Passeata vão o Festeiro e Capitão de Mastro levando as Bandeiras do Divino. A Festeira segura a coroa e a Capitã do Mastro, o cetro. A Folia do Divino está no meio das muitas pessoas que seguem para a residência de um ex-festeiro, conforme agendado.

\section{pdfMachine}

\section{A pdf writer that produces quality PDF files with ease!}

Produce quality PDF files in seconds and preserve the integrity of your original documents. Compatible across nearly all Windows platforms, simply open the document you want to convert, click "print", select the "Broadgun pdfMachine printer" and that's it! Get yours now! 


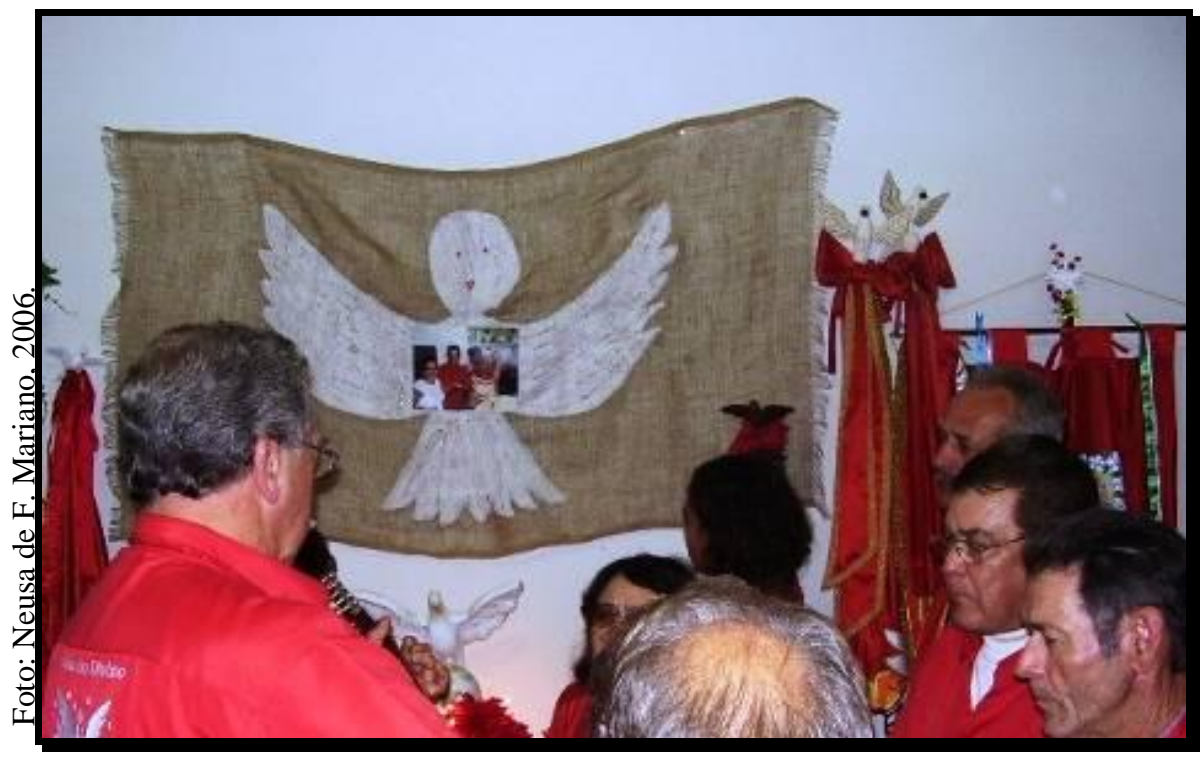

Sob o comando de Mestre Ulisses, a Folia canta, acompanhada pelos instrumentos musicais, ao se despedir da família que os recebeu:

O senhor e sua família/ Licença queira nos dál O meu Divino vai emboral e nós queremo acompanhá, eh!! (CAMPOS, 2001: 18).

Foto 24.

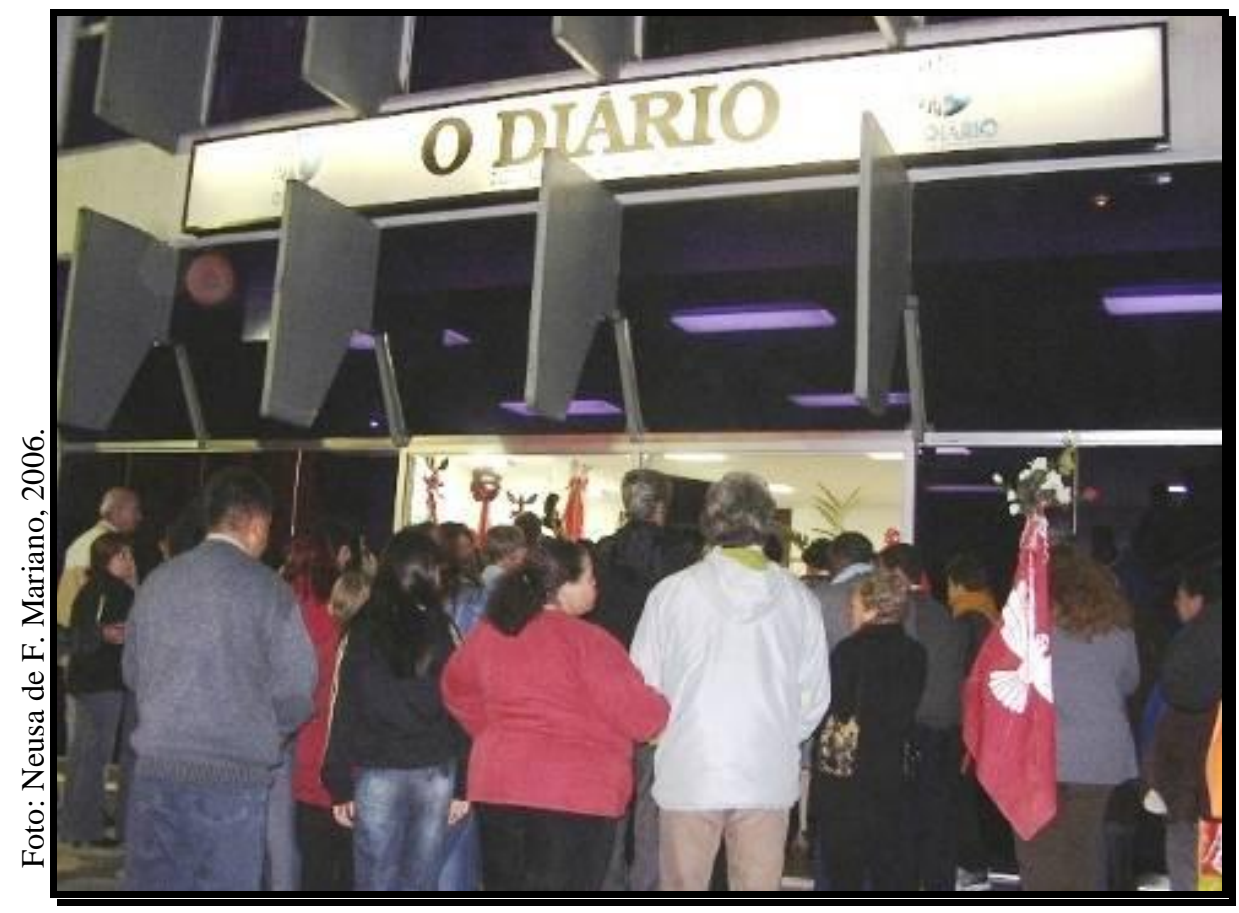

Localizado no centro de Mogi das Cruzes, o Jornal O Diário de Mogi recebe a Passeata das Bandeiras todos os anos. No seu interior está montado um Subimpério e, após a Folia do Divino cantar e o dono do Diário proferir algumas palavras, é servido pão acompanhado de café preto.

\section{pdfMachine}

A pdf writer that produces quality PDF files with ease!

Produce quality PDF files in seconds and preserve the integrity of your original documents. Compatible across nearly all Windows platforms, simply open the document you want to convert, click "print", select the 
A Folia do Divino, depois da caminhada noturna, acompanha o primeiro evento de cada dia: a Alvorada. Tendo início no primeiro sábado da Festa, segue até o domingo de Pentecostes, completando nove dias. Trata-se de uma caminhada a partir das 5:00h da manhã, sob os primeiros raios de sol do dia - simbolicamente, a luz do Espírito Santo. Algumas pessoas enfrentam o frio de maio/junho para pagar promessa; outras fazem sacrifício, participando todos os dias da Alvorada, mesmo que depois tenham que enfrentar um dia normal de trabalho. Há aqueles que fazem o percurso descalços e há ainda os que vestem seus filhos com túnicas e asas, representando anjos.

Partindo sempre do Império do Divino, a Alvorada percorre ruas do centro da cidade $^{128}$ e dura em média uma hora; geralmente alguém "puxa", com o auxílio de um microfone, as orações da Coroa do Divino (Anexo B) e os cânticos (Anexo C) durante a procissão. Assim como na Passeata das Bandeiras, os Festeiros e Capitães de Mastro vão à frente, logo após os Lanterneiros que iluminam o caminho.

A primeira segunda-feira da Alvorada, dia normal de trabalho, é considerada bastante especial, pois a caminhada da madrugada leva os fiéis, sempre portando suas bandeiras, até o Cemitério São Salvador (Mapa 6), local onde é celebrada uma missa em intenção de Festeiros, Capitães de Mastro e devotos já falecidos (Fotos 25 e 26). Como a capela do cemitério é muito pequena, os devotos assistem à missa do lado de fora, por um telão, colocado logo à frente da mesma. Este é o dia da Alvorada mais demorada, pois há a integração de uma missa, celebrada pelo Bispo Diocesano de Mogi das Cruzes. Do Cemitério seguem, ainda em procissão, até o Império do Divino, onde há o encerramento do ritual. Neste momento, voluntários aguardam os devotos no salão da Catedral de Santana, para distribuir biscoitos de Santo Antonio (que alguns chamam "biscoito de Mogi", ou ainda, "biscoito caipira"), pão com mortadela e café preto. Festeiros e Capitães de Mastro, reunidos com os voluntários que prepararam o café da manhã, juntamente com os devotos que já se encontram no salão, rezam em frente ao Subimpério ali montado. Agradecem, antes, pelo alimento que será servido. Fila de devotos rodeia a Catedral de Santana, para receber o alimento (Foto 27).

128 Diferente da Passeata das Bandeiras na Alvorada nã há visita a residências ow emnresac pdfMachine A pdf writer that produces quality PDF files with ease!

Produce quality PDF files in seconds and preserve the integrity of your original documents. Compatible across nearly all Windows platforms, simply open the document you want to convert, click "print", select the "Broadgun pdfMachine printer" and that's it! Get yours now! 
No dia seguinte (terça-feira), a Alvorada faz uma parada em frente à Santa Casa de Misericórdia (Mapa 6) onde são rezados o Pai-Nosso e a Ave Maria pela intenção dos enfermos. Logo após, segue-se o trajeto previamente estabelecido pelos organizadores da Festa.

No Domingo de Pentecostes, último dia da Alvorada, acontece o ritual da fogueira, em que a procissão é recebida pelas pessoas que ficaram em vigília na igreja Nossa Senhora do Carmo (Mapa 6). Em frente a essa igreja é acesa uma fogueira, e feita a celebração com todos os fiéis, que se acomodam na Praça do Carmo. O fogo tem importante significado neste momento, pois representa o próprio Espírito Santo, que logo ao amanhecer, pousa sobre a Terra, conforme a promessa de Cristo, que o enviaria cinqüenta dias após a sua ressurreição, ou seja, em Pentecostes.

O Padre (que estava em vigília) invoca o Espírito Santo e pede aos devotos que imponham suas mãos, uns sobre as cabeças dos outros, e orem para que "Ele" ilumine suas vidas (Foto 28). Juntamente com a Alvorada que segue até o Cemitério, esta tem maior participação dos devotos, com a vantagem de acontecer na madrugada de um domingo.

Como ocorreu nos dias anteriores, o fechamento da Alvorada acontece no Império do Divino, com versos cantados e música tocada pela Folia do Divino de Biritiba Ussu. 


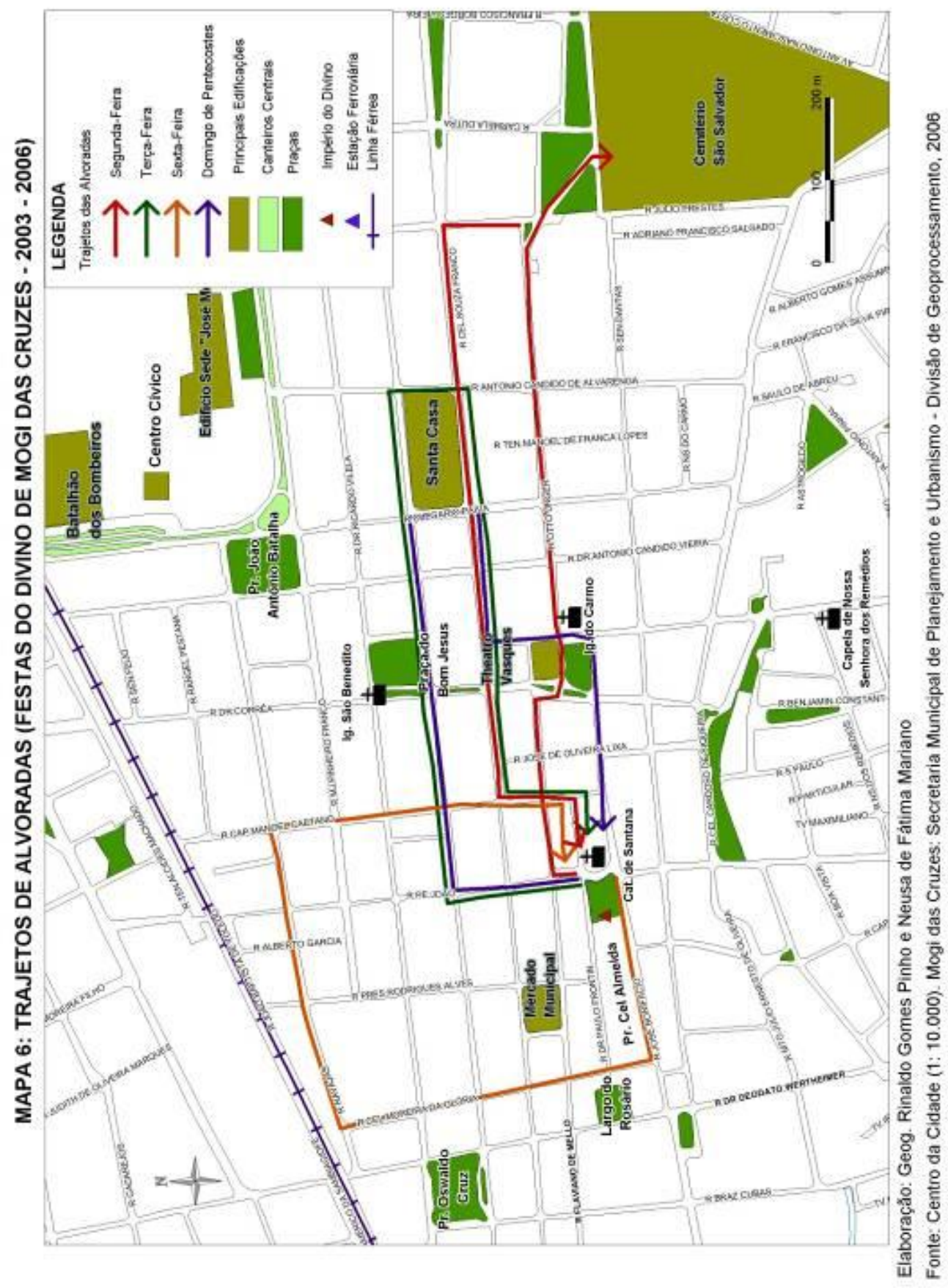

pdfMachine

A pdf writer that produces quality PDF files with ease!

Produce quality PDF files in seconds and preserve the integrity of your original documents. Compatible across nearly all Windows platforms, simply open the document you want to convert, click "print", select the 
Foto 25.

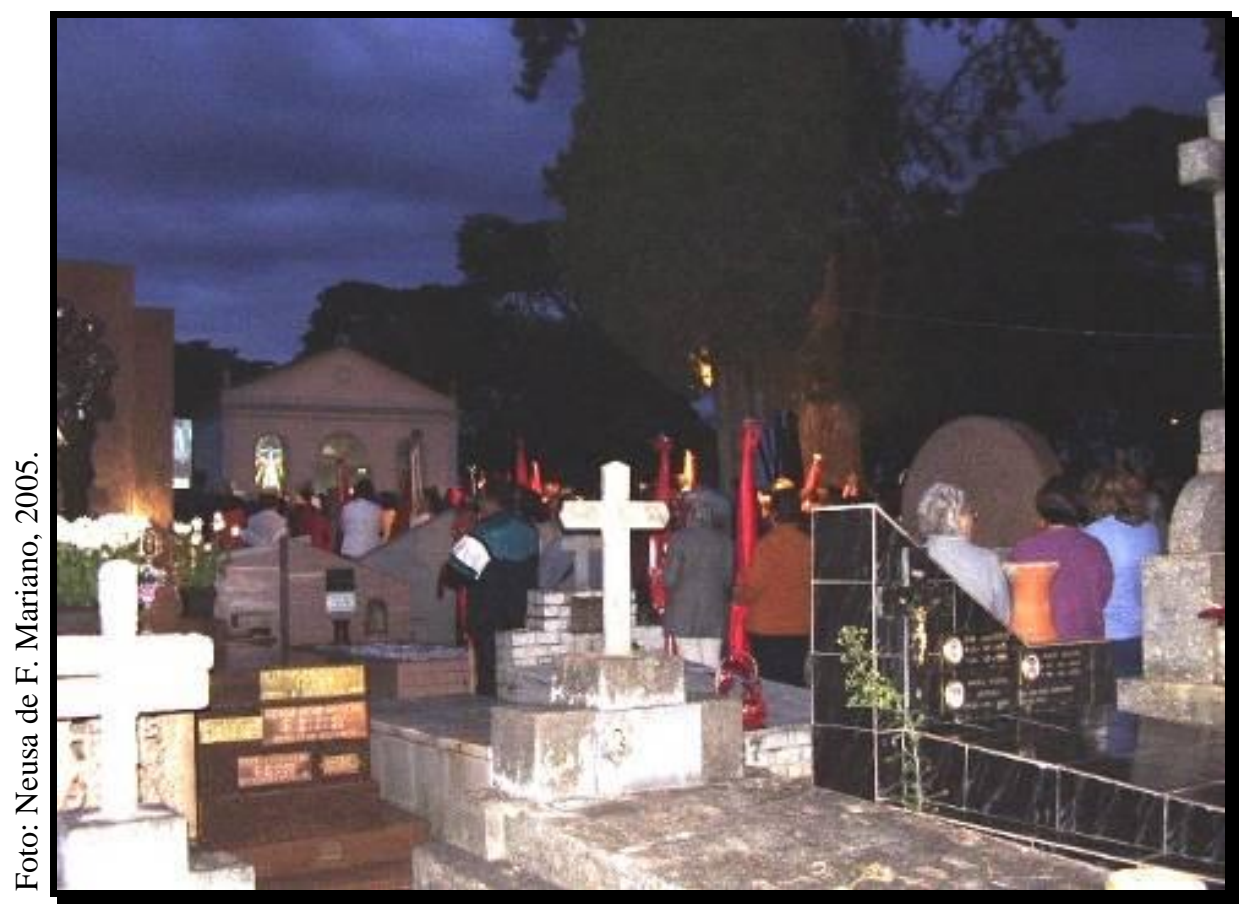

Mas não dava para entrar! Eu procurei um portão grande, primeiro, ali em frente à capela. Não consegui entrar. Mas olha! Não consegui... Então eles puseram telões grandes, que todo mundo via. Era assim, muito grande.

Dina

Foto 26.

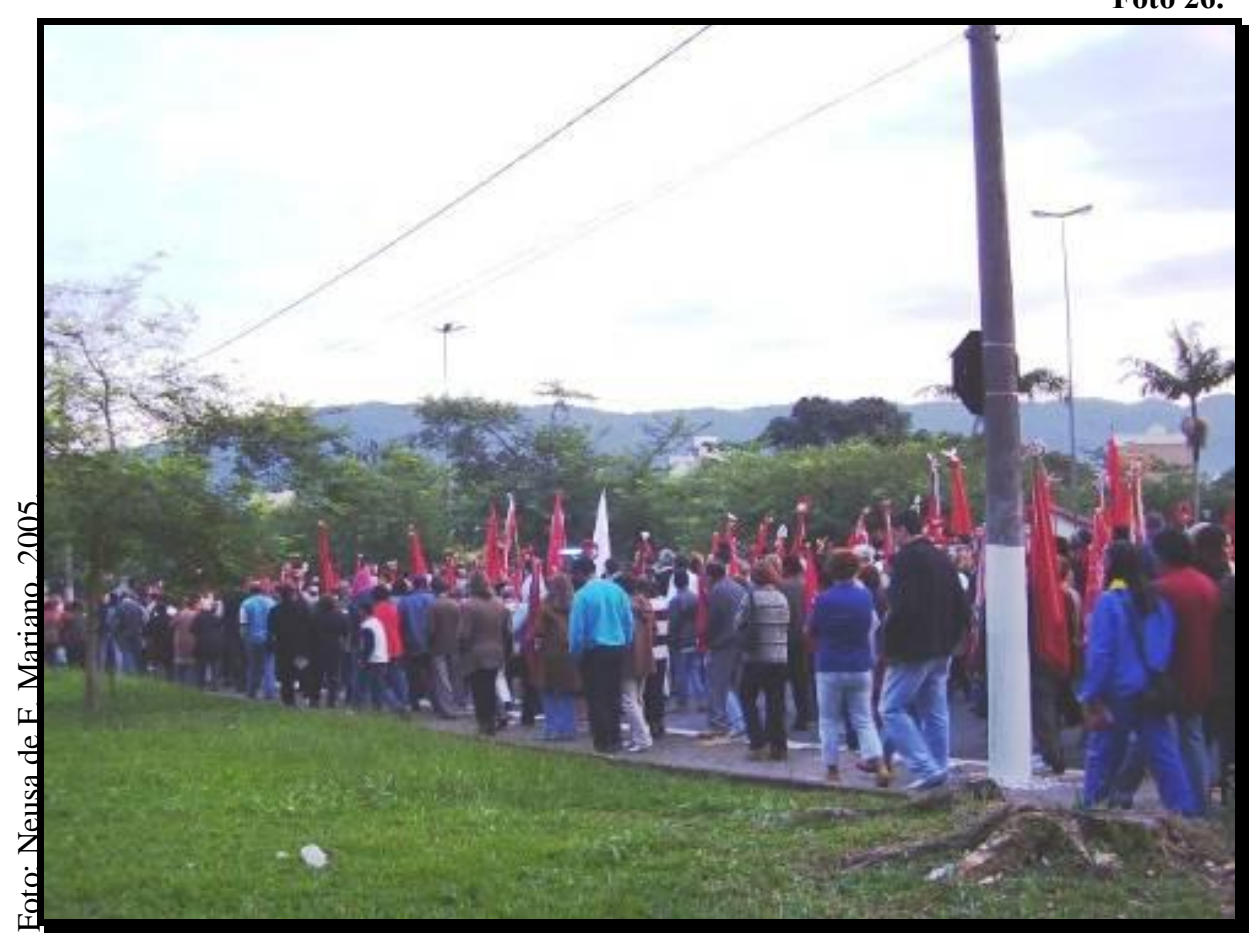

Com o dia claro, após a Missa da Alvorada no Cemitério São Salvador, os devotos caminham de volta ao Império do Divino.

\section{pdfMachine}

A pdf writer that produces quality PDF files with ease!

Produce quality PDF files in seconds and preserve the integrity of your original documents. Compatible across

nearly all Windows platforms, simply open the document you want to convert, click "print", select the

"Broadgun pdfMachine printer" and that's it! Get yours now! 
Foto 27.

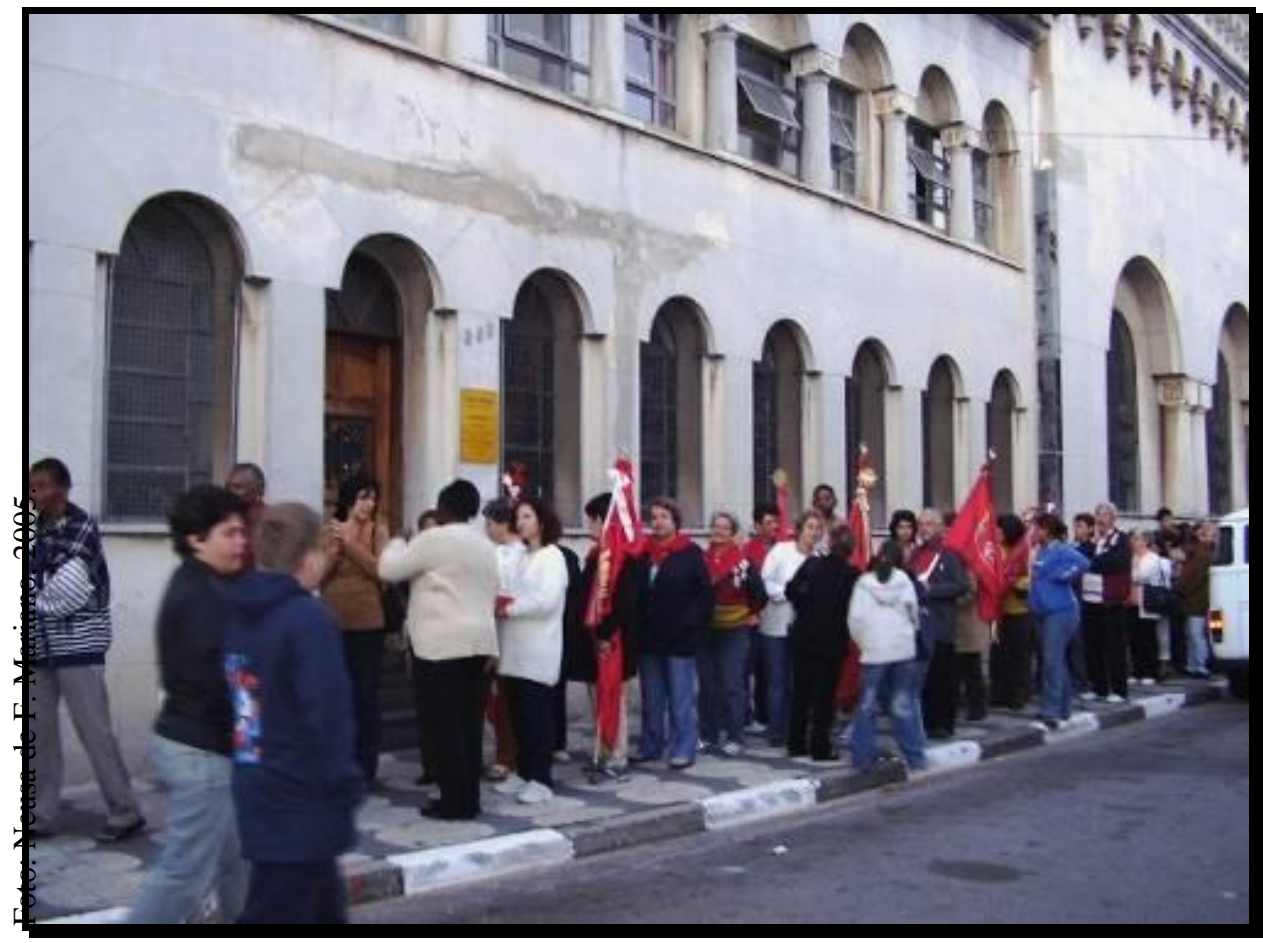

Devotos aguardam em fila para, juntos, tomar o café da manhã, o café do Divino.

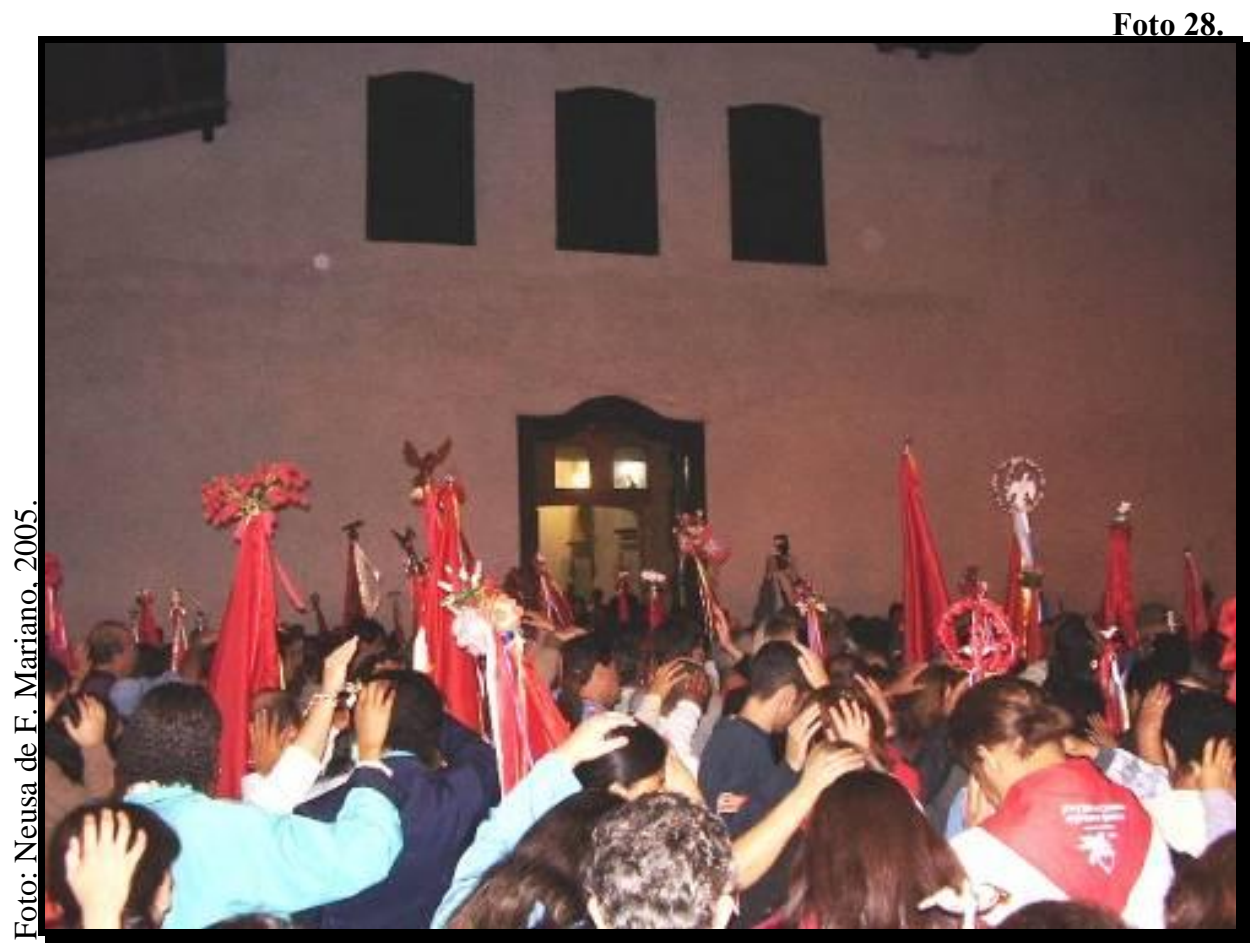

Espírito Santo pousa sobre a Terra, durante ritual da Alvorada, em frente à igreja de Nossa Senhora do Carmo. O sol ainda está nascendo.

\section{pdfMachine}

A pdf writer that produces quality PDF files with ease!

Produce quality PDF files in seconds and preserve the integrity of your original documents. Compatible across

nearly all Windows platforms, simply open the document you want to convert, click "print", select the

"Broadgun pdfMachine printer" and that's it! Get yours now! 
Houve uma grande redução da atuação da Folia do Divino, da longa peregrinação antes do período festivo, para as visitas noturnas (junto com a Passeata das Bandeiras) a residências de devotos. Acrescente-se a isso que as casas são previamente agendadas, que se oferece bolo, lanche, café, refrigerante especialmente preparados para a ocasião (ninguém é surpreendido com a visita), que tem hora para começar (depois da missa da Novena que termina por volta de 21:00h) e não pode se estender muito porque na madrugada do dia seguinte, tem que estar na Alvorada. As residências previamente selecionadas parecem não incluir aquelas onde há enfermos, como foi um dia, sendo praticamente as mesmas em todos os anos. Observa o Sr. Ulisses: "Mas antes ainda, quando começou [em Mogi das Cruzes], a gente chegava nas casas das pessoas que não podiam ir na Festa. Gente doente, de cama. Hoje em dia, agora não”.

É notável, além da redução do papel da Folia do Divino, a perda da identidade do grupo, pois muitos se referem à Folia do Divino como "os violeiros” (somente o Mestre, Sr. Ulisses, toca viola). Tal fato é um indício que de há um processo no qual é extraído da Folia do Divino o seu caráter religioso e sagrado, passando ela a ser considerada um grupo de "tocadores de viola", para animar a Passeata das Bandeiras e as Alvoradas.

\subsubsection{Os Palmitos chegam à cidade}

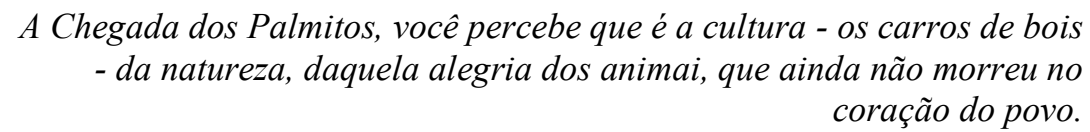

Cida

A Entrada dos Palmitos, manifestação considerada folclórica, é momento dos mais importantes na Festa do Divino de Mogi das Cruzes. Ocorre no sábado, véspera do Dia de Pentecostes, a partir das 10:00h.

Mário de Andrade (1937: 62) entende que o palmito e os carros de bois presentes no cortejo, não são meras adaptações, mas "produtos derivados mais profundamente da 
tradição”. Segundo o autor, como já ressaltado em outra parte deste trabalho, há forte ligação entre a Entrada dos Palmitos e as tradições européias como, por exemplo, a prática de se plantar uma árvore-de-maio diante de cada casa, ou de conduzir uma árvore de porta em porta, com o objetivo de trazer os benefícios que o espírito da árvore concede, durante as festas realizadas no mês de maio. Trata-a, assim, como reminiscência do culto vegetal da primavera, permanecendo o mês de maio, mas mudando a estação do ano no Brasil.

A Entrada dos Palmitos consiste em um grande cortejo, que parte da Capela de Santa Cruz (Mapa 7), da qual participam devotos com bandeiras do Divino, Festeiros e exFesteiros, Capitães e ex-Capitães de Mastro, autoridades municipais, casal de crianças representando o Imperador e a Imperatriz do Divino, Banda de Música Santa Cecília, grupos de Congada e Moçambique, Banda de Clarins da Cavalaria da Polícia Militar, várias Irmandades e Paróquias, carros de bois, carroças, charretes, cavaleiros, etc.

A Entrada dos Palmitos percorre as Ruas Dr. Ricardo Vilela até a Praça Oswaldo Cruz, passa pela Rua Dr. Deodato Weitheimer e alcança a Rua José Bonifácio, se dispersando logo após a passagem em frente à Catedral de Santana (Mapa 7). O cortejo é assistido pelas autoridades (de um palanque montado para este fim), por devotos, curiosos e turistas; ao todo, em 2006, cerca de cinqüenta mil pessoas, conforme notícia no jornal O Diário de Mogi (06/06/2006).

Algumas alas - vamos chamar assim - se manifestam com música, como a Banda Santa Cecília, grupos escolares, Folia do Divino dos Açores da Penha, etc.; outras cantam e dançam como os grupos de Congada e Moçambique; na ala dos cavaleiros, destacam-se os tocadores de berrantes; há ainda as alas dos que rezam e outras que apenas desfilam em silêncio, carregando a bandeira do Divino.

A abertura do desfile se dá com os escoteiros, desde crianças de cinco anos de idade, até adolescentes, com cerca de treze anos. Eles distribuem pequenas bandeiras do Divino, feitas de papel, para a população que foi prestigiar o cortejo. Nos anos de 2005 e 2006, houve também a distribuição de um texto explicativo sobre a Entrada dos Palmitos ${ }^{129}$, (ANEXO E) com o intuito de divulgar a tradição e as origens da Festa do Divino.

129 Texto de autoria de Insemir Ferraz de Camons e Marize Helena de Camnos 


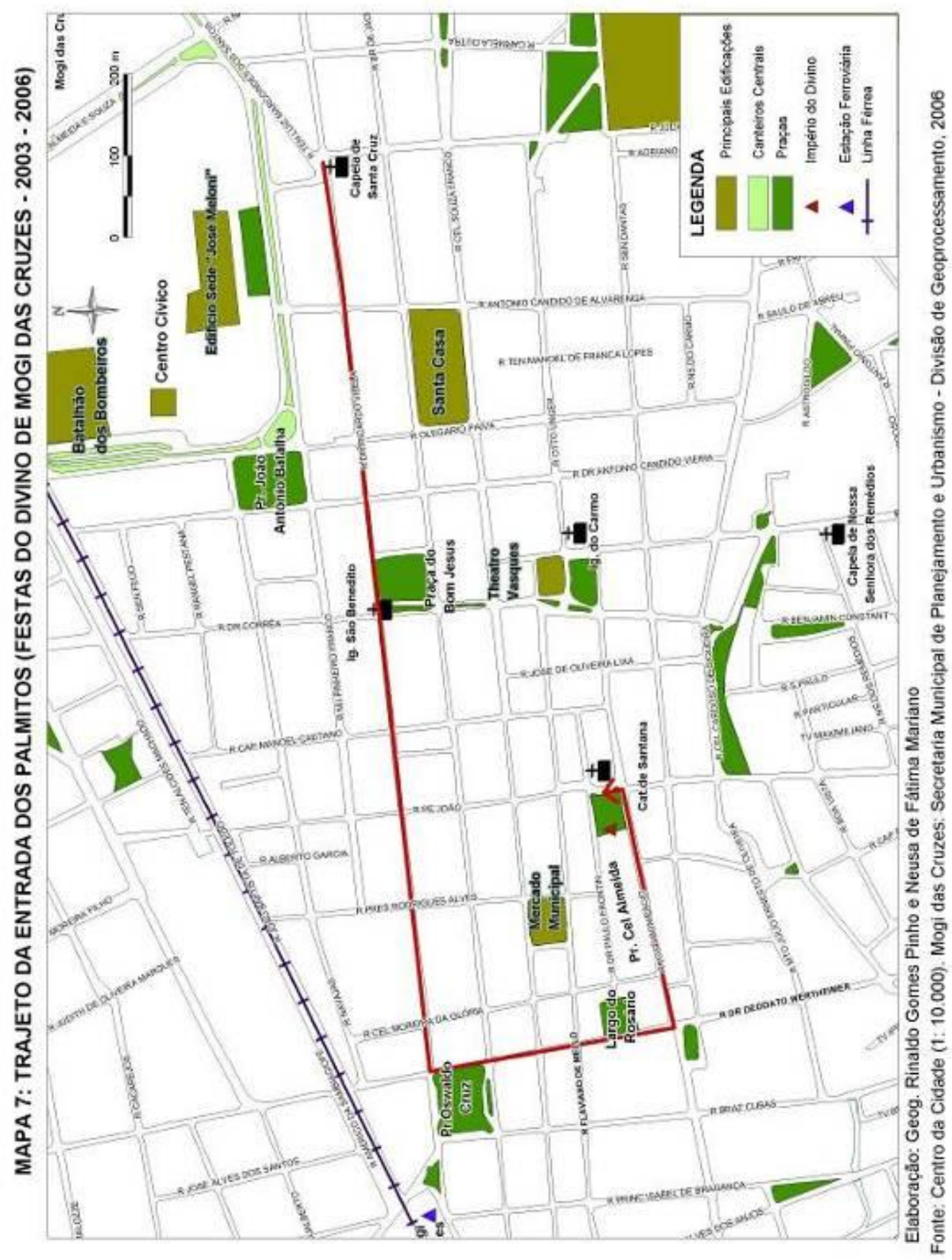

pdfMachine

A pdf writer that produces quality PDF files with ease!

Produce quality PDF files in seconds and preserve the integrity of your original documents. Compatible across nearly all Windows platforms, simply open the document you want to convert, click "print", select the 
Na seqüência vêm os chamados "grupos folclóricos", todos de Mogi das Cruzes, que participam da Festa do Divino, e se alternam em suas manifestações (canto e dança) durante o cortejo (Fotos 29-31). São eles, com suas respectivas datas de fundação: Congada Nossa Senhora do Rosário (1956), Congada de São Benedito (1961), Moçambique de São Benedito e Nossa Senhora do Rosário (1971), Moçambique de São Benedito, Bom Jesus e Nossa Senhora do Rosário (1977), Congada de Santa Efigênia (1984), e Batalhão Nossa Senhora Aparecida (2003) ${ }^{130}$.

Cada grupo é identificado pelo estandarte com o santo de devoção, e pelas cores de seus uniformes. A Congada de Santa Efigênia, por exemplo, é caracterizada pelo verde e branco em seu figurino. Segundo Gislaine, a Capitã do grupo, essas são as cores escolhidas pelo seu falecido pai - fundador da Congada - e representam a esperança e a paz, respectivamente. Lúcia, da Congada Nossa Senhora do Rosário, explica o significado das cores do grupo: "As cores do boné vêm do arco-íris, chamadas cores de Deus. As cores azuis vêm dentro da capa de Nossa Senhora, e a cor branca vem da paz."

Os grupos se diferenciam entre si através também da batida dos instrumentos, (geralmente percussivos: caixas, surdos, zabumbas, pandeiros e bastões); através do manejo dos bastõezinhos, no caso, dos grupos de Moçambique, e dos personagens que são representados, como Rainha, Rei, Porta-Estandarte, Bandeireiros, Princesas. Mas, claro, cada grupo possui o seu Mestre ou Capitão que o dirige.

Talvez pela dimensão que a Festa do Divino esteja tomando em Mogi das Cruzes, hoje muito divulgada na mídia, é notável o crescimento destes grupos, com a presença de muitos jovens que talvez não entendam o significado da dança da qual participam ${ }^{131}$. Parece

${ }^{130}$ Conforme entrevistas e o site: http://www.festadodivino.org.br - acesso em 17/08/2006.

${ }^{131}$ Parece que somente o comandante do grupo detém certo conhecimento sobre a origem e o significado da dança. Mas é importante observar que há versões diferentes para a origem da Congada. Em 1933, Mário de Andrade (2002) já havia percebido confusões por parte do Mestre de Moçambique, com relação à origem da dança. As contradições permanecem nos dias de hoje, conforme pudemos constatar nas entrevistas realizadas com Mestres e Capitães de Congada e Moçambique. Para o Sr. José Tavares (Mestre do Moçambique de São Benedito e Nossa Senhora do Rosário), a prática da dança teve início em 1520, com a história de dois fazendeiros, um negro e um branco. Um dia, o fazendeiro negro quis comprar a fazenda do seu vizinho, que lhe impôs a condição de não derrubar a capela de Nossa Senhora do Rosário. O comprador, ao aceitar a proposta, manteve também a capela de sua propriedade, de São Benedito. Quando o negócio foi feito, festejou-se em homenagem aos dois santos, mantendo-se até hoje a tradição da dança em sua devoção. Porém, a versão do Sr. Nego Otaviano, Capitão do Batalhão Nossa Senhora Aparecida, e do Sr. Dico, da Congada Nossa Senhora do Rosário, é outra: uma imagem de Nossa Senhora do Rosário estava no rio. seus devotos a huscaram a a colocaram de volta na sua canela. no dia pdfMachine

A pdf writer that produces quality PDF files with ease!

Produce quality PDF files in seconds and preserve the integrity of your original documents. Compatible across nearly all Windows platforms, simply open the document you want to convert, click "print", select the "Broadgun pdfMachine printer" and that's it! Get yours now! 
que para eles, saber que a dança representa a história de um povo escravizado, tolhido de praticar as suas crenças religiosas oriundas da África, é o essencial. Para Sebastiana, Rainha da Congada de São Benedito, o grupo manifesta, antes de tudo, forte religiosidade, por isso nega que integra um "grupo folclórico". Assim, separa a religiosidade do folclore, este entendido como exótico, pitoresco, colorido. As pessoas que assistem às apresentações dos grupos de Congada e Moçambique, os identificam como folclóricos, sem deixar de reconhecer neles a religiosidade, principalmente por causa do canto, que acreditam ser orações (Anexo F).

Cabe lembrar que a Entrada dos Palmitos que, segundo o jornal O Diário de Mogi (06/06/2006) contabiliza cerca de 2000 pessoas desfilando, é considerada, conforme a programação oficial, parte folclórica da Festa do Divino. Na sua grandiosidade, a Entrada dos Palmitos permite a participação de tudo o que possa ser identificado como folclore, como declara Caíque:

Em 2001 [quando foi Festeiro] com os bonecões da AMDEM, e com os que eu trouxe do Vale do Paraiba, foram dezesseis grupos. Eu trouxe a Folia de Reis, eu trouxe todo mundo para se apresentar porque eu entendo hoje que a Entrada dos Palmitos é resgatar e lembrar a simbologia e a resistência da cultura, e mostrar para o povo que existe grupo folclórico.

Os bonecões da AMDEM - Associação Mogicruzense para Defesa do Menor - são bonecos gigantes feitos de papel marchê, que representam alguns personagens importantes da Festa do Divino como o cozinheiro do "Afogado", o Lanterneiro, etc.

A Entrada dos Palmitos, que representa a antiga chegada da população rural para a Festa do Divino na cidade, trazendo o excedente de sua produção, tornou-se cada vez mais atrativa e, os organizadores do cortejo, ao perceberem isso, aproveitaram o seu potencial, sob o discurso do "resgate da tradição", para divulgar a Festa e inserir nela elementos do folclore brasileiro. Desta forma, grupos oriundos de outros locais, são convidados a se apresentar no cortejo. É o caso, entre outros já citados, do grupo de trança fitas "Ô de Casa!"132, da Vila Sabrina, cidade de São Paulo (Foto 32). A coreografia do grupo envolve

seguinte, a mesma imagem voltava para o rio; somente após um grupo de negros a buscarem num ritual de batuques e danças é que a imagem de Nossa Senhora do Rosário ficou na capela, sem nunca mais sair. Desde então, grupos de Congada e Moçambique dançam em homenagem a Nossa Senhora do Rosário.

${ }^{132}$ Grupo fundado por volta do ano de 2000, cujo núcleo principal é a família do Sr. Eli (o Mestre do grupo), foi formado a partir de pesquisas bibliográficas, ou seja, não se explica por tradição oral, por uma heranca familiar o orual Assim somo tantas dancas nowlares no Rrasil o Tranca Fitas foi pdfMachine

A pdf writer that produces quality PDF files with ease!

Produce quality PDF files in seconds and preserve the integrity of your original documents. Compatible across nearly all Windows platforms, simply open the document you want to convert, click "print", select the "Broadgun pdfMachine printer" and that's it! Get yours now! 
moças devidamente uniformizadas, sempre em número par, que seguram as pontas das fitas vermelhas e azuis que estão presas ao topo do mastro, formando um círculo em sua volta. Conforme os passos que elas dão, o mastro vai sendo enfeitado com as fitas, formando trançados diferentes. Como se trata de um desfile, uma pessoa carrega o mastro enquanto a dança se desenvolve. Originalmente, porém, o mastro ficava imóvel para que a evolução da dança acontecesse tranquilamente. Ou seja, há um esforço do grupo em se ajustar às condições que a Entrada dos Palmitos impõe.

Outro grupo paulistano, frequentemente convidado a participar da Entrada dos Palmitos, é a Folia do Divino Açoriana, proveniente do bairro da Penha. Eles tocam bandolim, viola caipira, cavaquinho, violão e trazem bandejas com um típico pão dos Açores (pão do Divino) e carne. Ao final do desfile, doam o alimento para os Festeiros e Capitães de Mastro, num ritual que se desenrola em frente ao Império do Divino.

Não só para o que se considera folclórico, pertencente ou não à realidade de Mogi das Cruzes, a Entrada dos Palmitos permite a inserção. Tomam parte do desfile também representantes políticos, como mostra matéria no jornal Mogi News $(04 / 06 / 2006)^{133}$ :

Autoridades como o prefeito Junji Abe (PSDB); o deputado estadual Luís Carlos Gondim Teixeira (PPS); o presidente da Câmara de Mogi, Rubens Benedito Fernandes, o Bibo (PP), além dos parlamentares José Antonio Cuco Pereira (PSDB) e Protássio Ribeiro Nogueira (PFL), participaram do cortejo.

Alguns destes representantes participavam do desfile na qualidade de ex-Festeiros (como era o caso de José Antonio Cuco Pereira, Festeiro do Divino em 2003), e todos eles seguiam ao lado dos Festeiros e Capitães de Mastro, sobre os quais são lançadas pétalas de rosas enquanto são aplaudidos (Foto 33). Casas das ruas por onde passa a Entrada dos Palmitos são decoradas com bandeiras, altares, flores, e delas, muitos assistem ao cortejo.

trazido pelos colonizadores portugueses, tendo como origem homenagens pagãs à natureza, seja para pedir ou para agradecer uma boa colheita. A prática da dança foi ficando cada vez mais rara devido a restrições impostas pela Igreja, que não aprovava a celebração pagã. Hoje, desvinculada de qualquer devoção, costuma ser apresentada em festas religiosas ou não. O objetivo do grupo é educar culturalmente, e divulgar o folclore brasileiro nas ruas, escolas, empresas, etc. Os personagens do grupo são a Rainha, que carrega o Estandarte com o nome do grupo, o Mestre que dirige a dança, e os dançarinos em número par. Se ocorrer de estarem em número ímpar, o sobrante dança como "Branca", ao lado da Rainha. Cantam e dançam "Cabelo Loiro", de Tião Carreiro e Pardinho, escolhida por ser uma música conhecida pelas pessoas que os acompanham na cantoria, e terminam com uma quadrinha de despedida. (Tânia e Thaís, componentes do grupo, em entrevista).

133 Acessado em marco de 2007 através do site httn //www festadodivino oro hr 
Ainda participam da Entrada dos Palmitos, os familiares de Nhá Zefa, crianças e jovens de várias Paróquias de Mogi das Cruzes, bem como algumas escolas que trazem cartazes referentes aos sete dons do Divino, com as cores que os representam.

A charola, o primeiro dos carros de bois, traz alimentos diversos, e representa os vegetais vindos do campo para a cidade (Foto 34). Ela dá início à seqüência de carros de bois. A charola foi retomada na Festa do Divino a partir de 1993, quando Dona Maria José $^{134}$ e o Sr. Miled foram Festeiros. Ao final da Entrada dos Palmitos, os alimentos da charola são doados às instituições de caridade: creches, asilos e afins.

O segundo carro de bois traz mudas de palmitos com o intuito de lembrar o costume antigo, quando palmitos eram trazidos pela população da Serra do Mar e da Serra de Itapeti, por ocasião da Festa do Divino de Mogi (Foto 35). Segundo o Sr. Josemir, a pedido da Associação Pró-Divino, a Prefeitura faz a poda das palmeiras das praças da cidade na véspera da Entrada dos Palmitos; assim os galhos das palmeiras são aproveitados para enfeitar os postes, em alusão à prática do passado. Uma conotação de preservação da natureza se faz presente nesse caso, somada à compra de mudas de palmito que serão distribuídas a várias entidades.

Os carros de bois, continua o Sr. Josemir, são encontrados, em sua maioria, fora de Mogi das Cruzes, pois no município este meio de transporte caiu em desuso. Eles são trazidos de Igaratá, Nazaré Paulista, Santa Isabel e Salesópolis e, em 2005, somaram vinte e três na Entrada dos Palmitos (O DIÁRIO DE MOGI, 14/05/2005). A dificuldade em encontrá-los decorre da extinção do uso de carros de bois como meio de transporte, inclusive nas atividades internas das fazendas. Os carros de bois chegam à cidade na tarde de sexta-feira, para o desfile do dia seguinte e ficam alojados em um terreno sob os cuidados da Associação Pró-Festa do Divino. No sábado, pela manhã, são enfeitados com flores de papel crepom ou naturais, e palmeiras. Crianças, organizadas pelas escolas, sob os cuidados de coordenadores da Associação Pró-Festa do Divino, desfilam dentro dos carros de bois (Foto 36). Todas as crianças, devidamente identificadas com crachás, recebem assistência de seus pais e professores que caminham ao lado. As carroças chegam ao número de cem $(\mathrm{O}$ DIÁRIO DE MOGI, 14/05/2005), e são mais fáceis de ser encontradas, compondo o cortejo logo após os carros de bois.

${ }^{134}$ Ela lembra que quando criança, na década de 1930 em Mogi das Cruzes, se encantava com a charola. nor isso awis retomá-la awando teve onortunidade 
Os cavaleiros que vêm na seqüência (Foto 38), não são contatados antes, e chegam ao número de quinhentos (O DIÁRIO DE MOGI, 06/06/2006). Conforme o Sr. Josemir, como os cavaleiros vão para o cortejo espontaneamente, a Associação Pró-Divino, que nunca sabe quantos serão, sente dificuldade em articular infra-estrutura para eles. Não só por isso os cavaleiros são alvo de preocupação dos organizadores da Festa, mas também pelo fato de que muitos deles não demonstram (aos olhos dos organizadores da Entrada dos Palmitos) consciência da tradição e da religiosidade da Festa do Divino, ao desfilarem com rádios e auto-falantes que entoam músicas sem referência alguma à Festa, ou ainda, ao se exibirem em seus cavalos como se estivessem em um concurso, ou algo assim...

Podemos aqui, lançar uma questão: não seria esta espontaneidade, expressão da alegria destes cavaleiros em participar da tradicional homenagem ao Espírito Santo, que os leva a tocar berrantes (Foto 37), a levar rádios que entoam músicas que não dizem respeito à festividade? Não seria essa a maneira encontrada por eles para festejar, numa tradução para a sua realidade, para a sua linguagem? Não fariam eles, parte da cultura popular?

Voltando ao cortejo. O resgate da Cavalhada ${ }^{135}$ na Festa do Divino tem sido preocupação freqüente do Sr. Josemir, e em 2002, o Grupo de Cavalhada de Guararema participou da Entrada dos Palmitos, fazendo uma apresentação no dia seguinte, pela manhã, no Ginásio Municipal de Esportes (Foto 40). A Cavalhada retrata a luta entre cristãos e mouros, terminando com a derrota e a conversão dos mouros ao cristianismo ${ }^{136}$.

Na ponta final do cortejo, está a Banda de Clarins da Polícia Militar, montada em cavalos. A pouca distância estão os garis, que participam trabalhando. Eles ficaram mais evidentes e eficientes a partir de 2005, pois logo que o cortejo foi passando, as ruas foram sendo limpas e, ao término da Entrada dos Palmitos, quase não havia vestígios do ocorrido.

Após circular pelas ruas próximas à Catedral de Santana, a Entrada dos Palmitos termina em frente ao Império do Divino (Foto 41). De lá há a dispersão dos grupos

${ }^{135}$ Há o registro da Cavalhada durante a Festa do Divino em Mogi das Cruzes, na década de 1930, quando Mário de Andrade colheu material filmográfico para a Missão de Pesquisas Folclóricas. O material faz parte do acervo do Centro Cultural São Paulo, como também do LISA, Laboratório de Imagem e Som do Departamento de Antropologia/ FFLCH/ USP.

${ }^{136}$ A Cavalhada é o ponto alto da Festa do Divino Espírito Santo de Pirinópolis (GO), onde os atores se vestem com armaduras e empunham espadas nas representações. Estas remetem ao século VIII, com Carlos Magno e os Doze Pares de França e sua luta contra os mouros. Essa história, que termina com a batalha vencida pelos cristãos de Carlos Magno, chegou ao Brasil pela via impressa que, ao longo do tempo, foi se modificando em alguns aspectos, devido às várias traduções, mas mantendo a sua estrutura aw foi difundida nelo território nacional $(C \Delta S C I D O 2001 \cdot 42,48)$ 
procurando-se evitar tumulto e liberar as vias públicas.

Os devotos seguem para o Centro de Iniciação Profissional Maurício Najar (CIP atual local da Quermesse) onde é distribuído o Afogado ${ }^{137}$ (Foto 42), carinhosamente apelidado de "Afogadão". O Sr. Airton explica como esse prato típico da Festa do Divino é feito:

O Afogado é uma comida que não é diferente do cozido português, do minestrone italiano, da feijoada e etc., [...] que eu acredito, nasceram de resto. O que vai fazer com o resto da batata? O que vai fazer com o resto da cenoura? O que vai fazer com o resto disso ou daquilo? Ou então, utilizando carnes que não eram normalmente usadas pelos "senhores da terra". Então, o Afogado era, na verdade, de carnes duras como costela e músculo. Carnes que ninguém utilizaria para pôr numa panela, porque demora muito para cozinhar. E são carnes extremamente gordurosas. Então, o Afogado nasceu de você colocar carnes gordurosas, sal, algum tempero, pimenta, etc., e água. Isso é o Afogado. E ele cozinha, para amolecer a carne, é no mínimo cinco, seis, sete horas de fogo. Então isso faz com que aquele caldo tenha muita sustância em razão da gordura que ele mantém. Bom, isso se você pegar desde Mogi das Cruzes até Cunha, você vai, todas essas localidades tem o seu Afogado, cada um com a sua particularidade. Em Mogi das Cruzes, deve ter seguramente cinqüenta receitas de Afogado. Cada família tem a sua. [...] Então ele, ele é feito assim: [...] põe o óleo pra esquentar, põe o alho, deixa ele dar uma fritadinha, dourar um pouquinho e colocamos a carne [...], ai deixa refogar. Põe umas doze, quinze cebolas bem picadinhas, uns quarenta tomates maduros, bem picados. Depois você põe uns oito pimentões; uns quinze jilós, um pé e meio de salsão; uns quinze maços de salsinha; depois você põe quase um quilo de sal. [...] Aí você põe manjericão, pimenta do reino e o louro. Tampa e deixa no fogo baixo. Ai, toda essa verdura é só água, e ela vai se decompondo e fazendo aquele caldo. [...] Então, você enche a panela de água, e deixa ferver ai mais uma hora, uma hora e meia. Aí põe a batata [...] e deixa ferver, cozinhar a batata. Quando ela estiver quase macia, desliga o fogo e deixa ela terminar de cozinhar naquela água quente. Toda a gordura vai subir. A gente tira mais ou menos, uns cinco litros de gordura. [...] Então é assim que é o Afogado. Serve-se muito quente. De preferência, no prato você coloca farinha de mandioca crua, umas três colheres de sopa, mais ou menos, três a quatro colheres. Joga o caldo quente, muito quente, que cozinha essa farinha.

${ }^{137}$ Os locais para a distribuição do Afogado aos devotos eram modificados a cada ano, conforme os acordos feitos pelos Festeiros: estacionamentos de supermercados, escolas públicas, etc.

Algumas entrevistas mostraram que muitos sabem preparar o Afogado, porém, com receitas e origens diferentes. Para Ana, por exemplo, o "Afogado" nasceu com os tropeiros que, originalmente não introduziam vegetais ao caldo de carne. Já o Sr. Marco Antonio, em uma rápida conversa, faz uma analogia do "Afogado" com a Feijoada, cuja origem relaciona-se à precariedade de alimentação dos escravos: da mesma forma, o Afogado é feito com restos de carne, incrementados com legumes. Dona Maria José diz que o nome original do "Afogado" é "Fogado", ou seja, algo que está no fogo. É que a carne demora para ser cozida, ficando muito tempo "fogada". Daí, continua ela, foi ficando

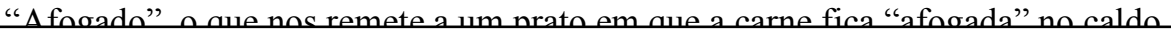


Feito conforme a receita perpetuada pelo Sr. Ezelino Franco (já falecido), o Sr. Airton coordena cerca de vinte e cinco voluntários que passam a madrugada cozinhando. $\mathrm{O}$ pessoal dos carros de bois é servido no acampamento onde se concentram desde o dia anterior, e os cavaleiros num rancho de uma pessoa da organização da Festa. Esta separação de participantes se dá para que haja uma maior rapidez e funcionalidade na distribuição do prato típico $^{138}$. Na contabilidade final, cinco mil pratos de Afogado são servidos na véspera de Pentecostes, logo após a Entrada dos Palmitos (O DIÁRIO DE MOGI, 06/06/2006).

Cabe ressaltar que o Afogado não é, para os devotos, simplesmente uma rememoração do passado, mas significa principalmente o alimento sagrado, bendito pelo Espírito Santo, carregado de boas energias, podendo até curar. A comida de festa "torna-se comida sagrada num lugar consagrado, ato cósmico e eficaz.” (LEFEBVRE, 1958: 219). Sendo assim, muitas pessoas buscam o Afogado para levar a alguém enfermo, acreditando no seu poder milagroso.

A comensalidade dos vários momentos da Festa do Divino (Passeatas, Café das Alvoradas e principalmente, "Afogadão") revela algo para além do religioso, pois pode representar o elo entre o homem e a natureza, na busca do equilíbrio, mesmo sob o caráter religioso do qual se reveste e, que um dia, fez parte de práticas consideradas pagãs, de relações mais imediatas com a natureza.

Por isso, há uma associação das festas populares religiosas ao período pós-colheita, período de fartura que deve ser partilhada pela comunidade que as realiza. Essas festas, geralmente ricas em alimentos - destacando-se aquelas em homenagem ao Espírito Santo -, mantêm os costumes festivos do período agrário, quando eram devoradas em um dia, as provisões que levavam meses para serem acumuladas.

138 Parece que em 2006 houve, por parte dos organizadores, uma preocupação maior para com o conforto dos que esperavam pelo "Afogado", fazendo diminuir o tempo de espera na fila, que já cheonu a ser de dwas horas somo em 2004 
Foto 29.

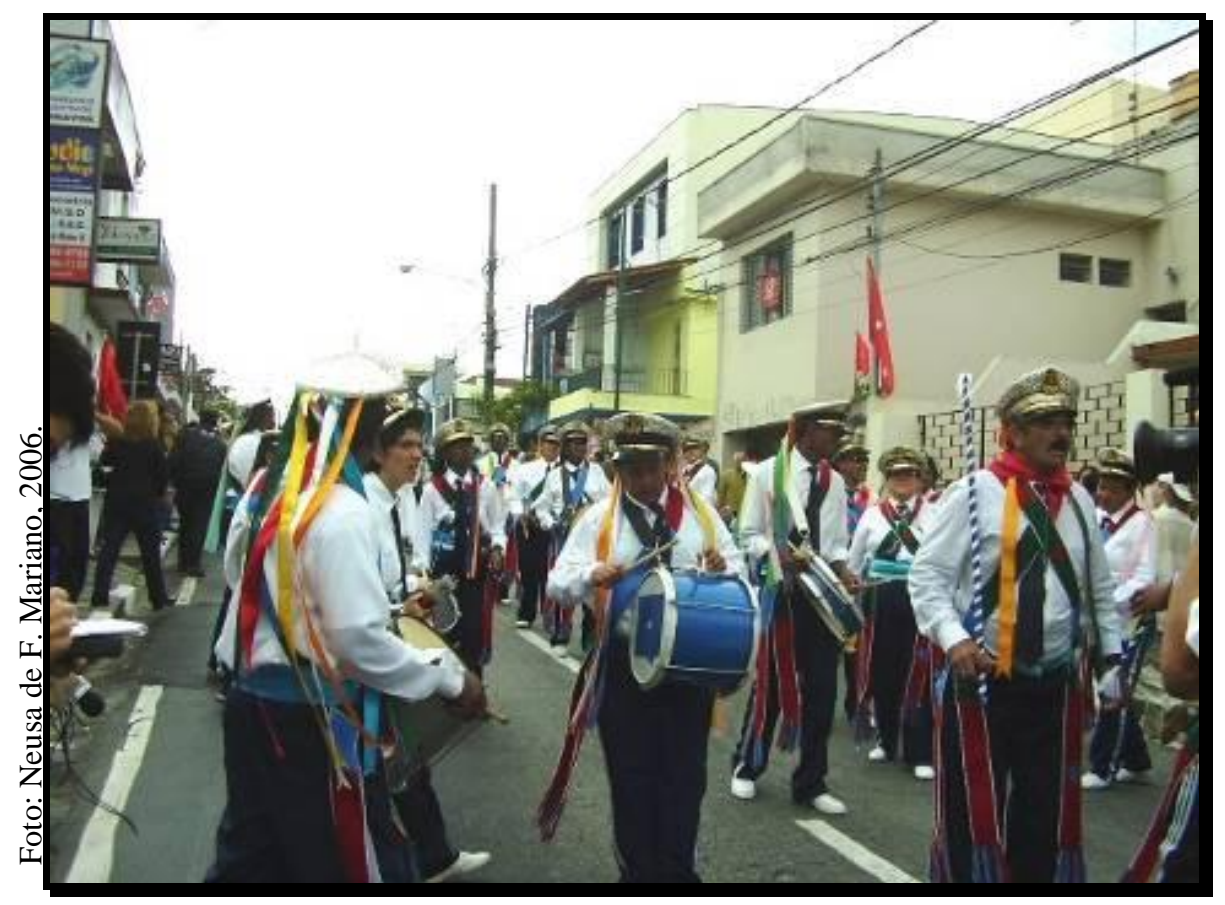

Até que hoje nosso folclore está bem revivido. No passado, a gente dançava menos do que hoje. A gente tinha uma festividade de uma ou duas vezes por... durante o ano todo. E hoje não. Hoje a gente participa das igrejas, participa das escolas, eventos culturais essas coisas. Então a gente participa muito mais que no passado.

Dico, Mestre da Congada Nossa Senhora do Rosário

Foto 30.

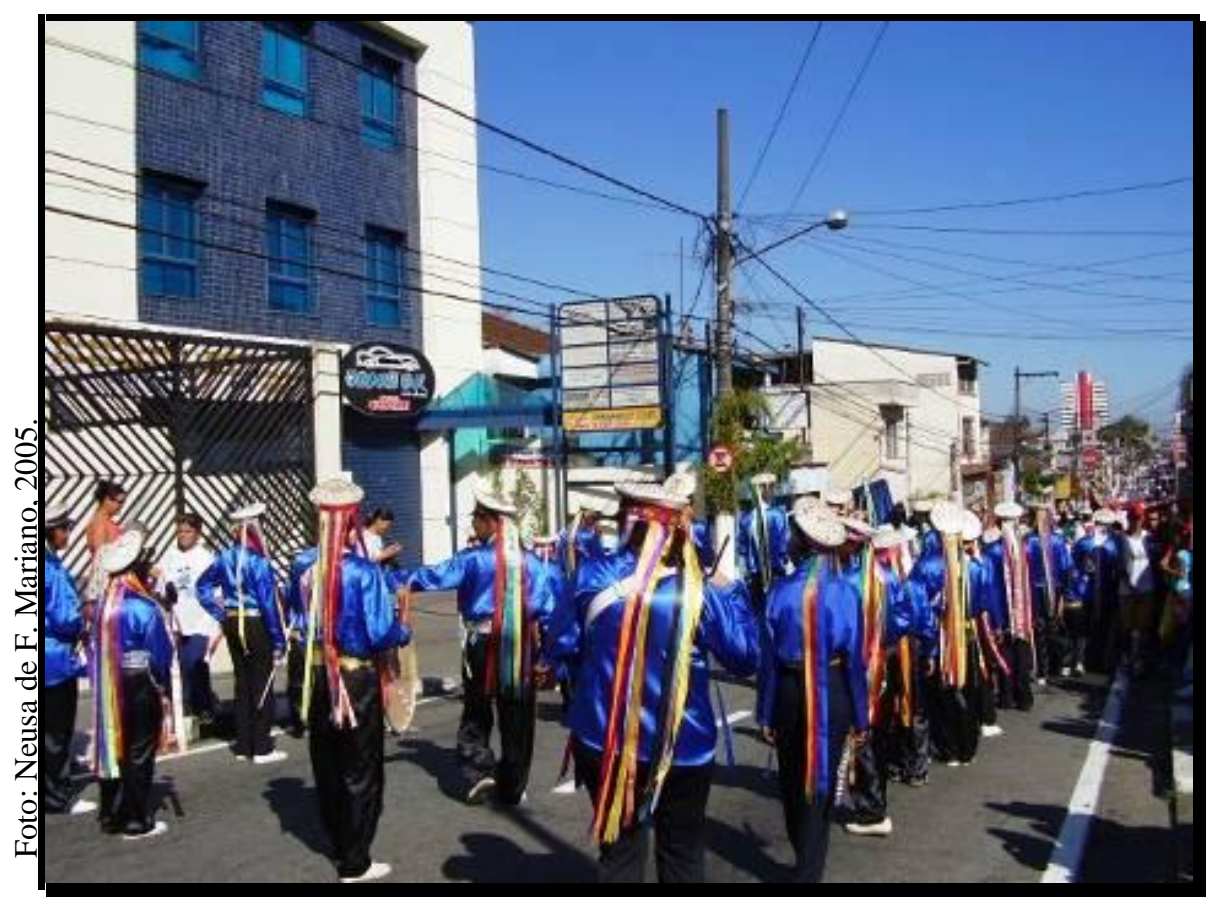

Assim canta o

Batalhão Nossa

Senhora Aparecida:

Fita vermelha, e fita amarela. Meu

batalhão vai entrar na passarela.

\section{pdfMachine}

A pdf writer that produces quality PDF files with ease!

Produce quality PDF files in seconds and preserve the integrity of your original documents. Compatible across nearly all Windows platforms, simply open the document you want to convert, click "print", select the "Broadgun pdfMachine printer" and that's it! Get yours now! 
Foto 31 .

O Moçambique é um folclore, é uma dança folclórica. Ele, segundo a história, vem de 1520.

Mestre José Tavares do Moçambique de São Benedito e Nossa Senhora do Rosário

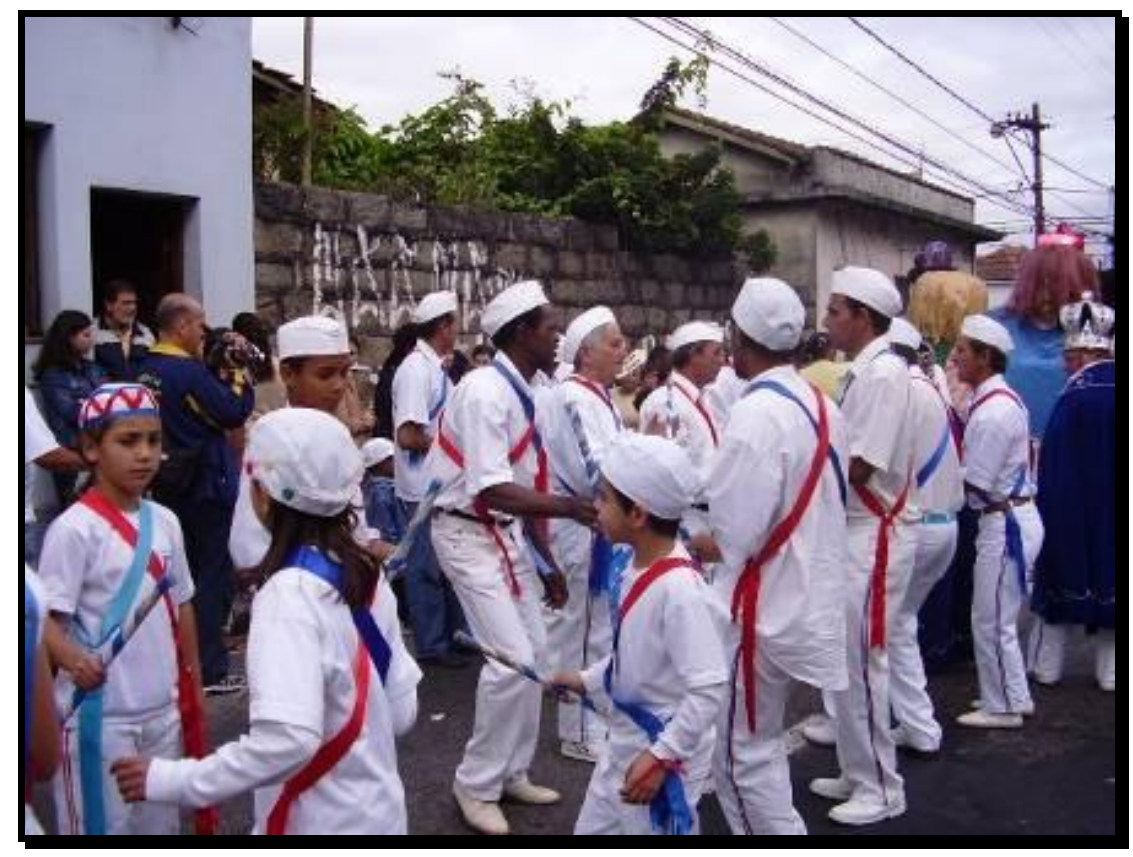

Foto: Neusa de F. Mariano, 2006.

Foto 32.

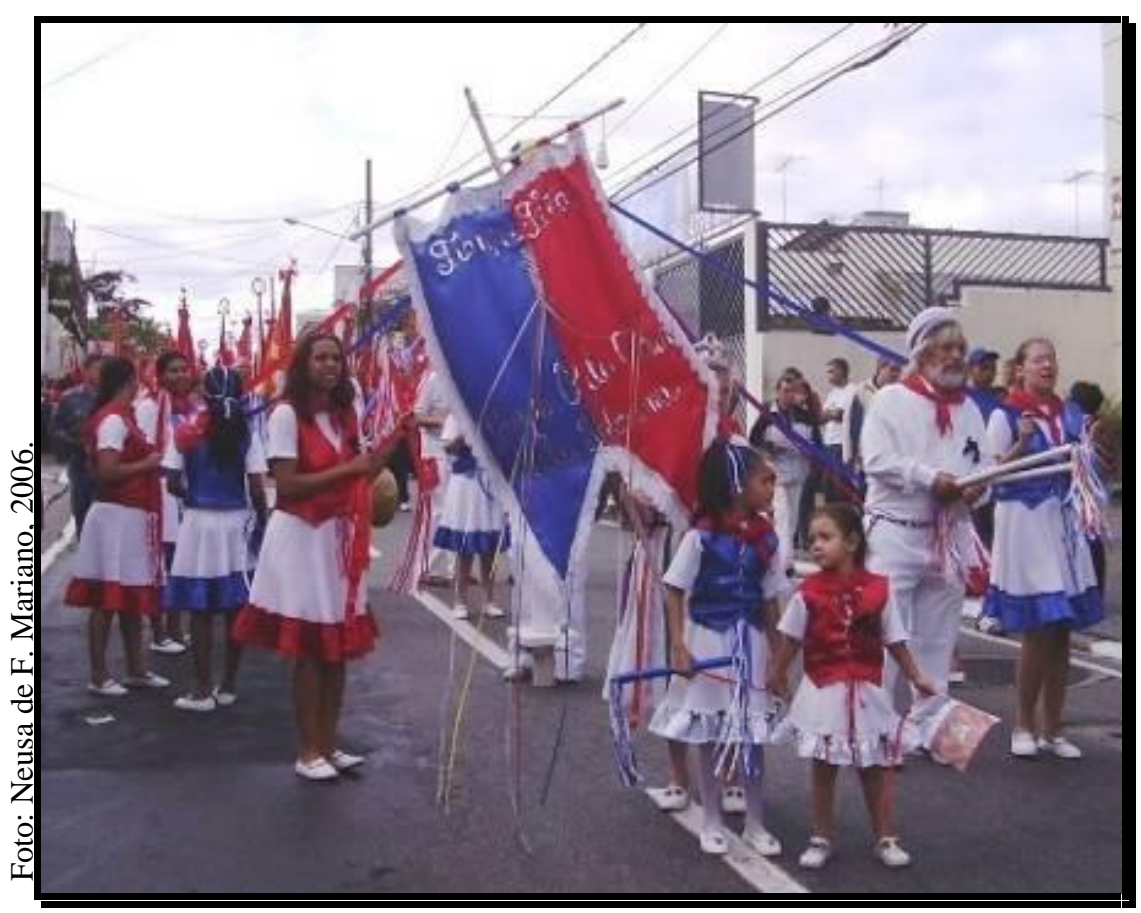

A gente não pode falar que nós somos devotos, não somos. Nós vamos pela parte folclórica, pela parte bonita, lúdica de ver a criatividade deles [devotos do Divino de Mogi das Cruzes], a luta deles de fazer tudo isso.

Thaís, do Grupo de Trança Fitas "Ó de Casa!"

\section{pdfMachine}

\section{A pdf writer that produces quality PDF files with ease!}

Produce quality PDF files in seconds and preserve the integrity of your original documents. Compatible across nearly all Windows platforms, simply open the document you want to convert, click "print", select the "Broadgun pdfMachine printer" and that's it! Get yours now! 
Foto 33.

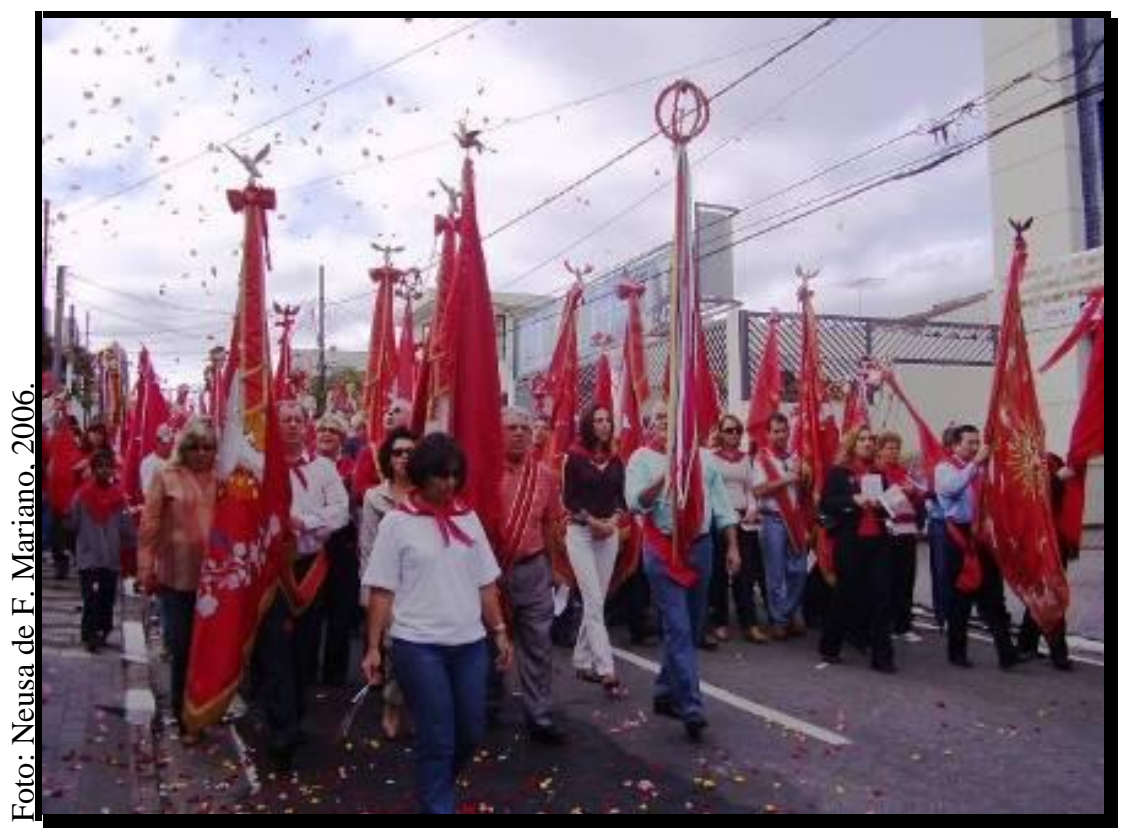

Festeiros, Capitães de Mastro, ex-Festeiros e ex-Capitães de Mastro, autoridades municipais participam da Entrada dos Palmitos, que portando suas bandeiras, são aplaudidos e recebidos com pétalas de rosas pelos devotos que os assistem.

Foto 34

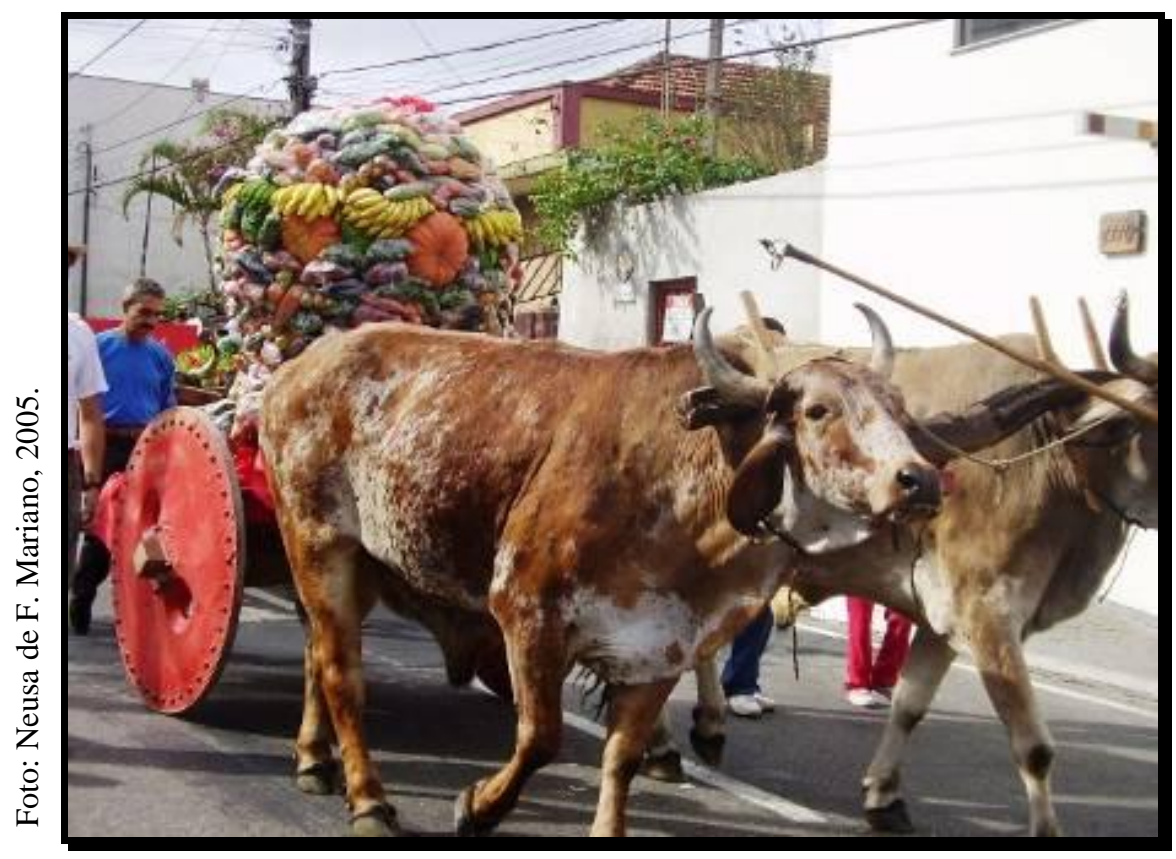

A charola vem no primeiro carro de bois do cortejo, montada com legumes e frutas, uma representação da fartura.

\section{pdfMachine}

A pdf writer that produces quality PDF files with ease!

Produce quality PDF files in seconds and preserve the integrity of your original documents. Compatible across nearly all Windows platforms, simply open the document you want to convert, click "print", select the "Broadgun pdfMachine printer" and that's it! Get yours now! 
Foto 35.

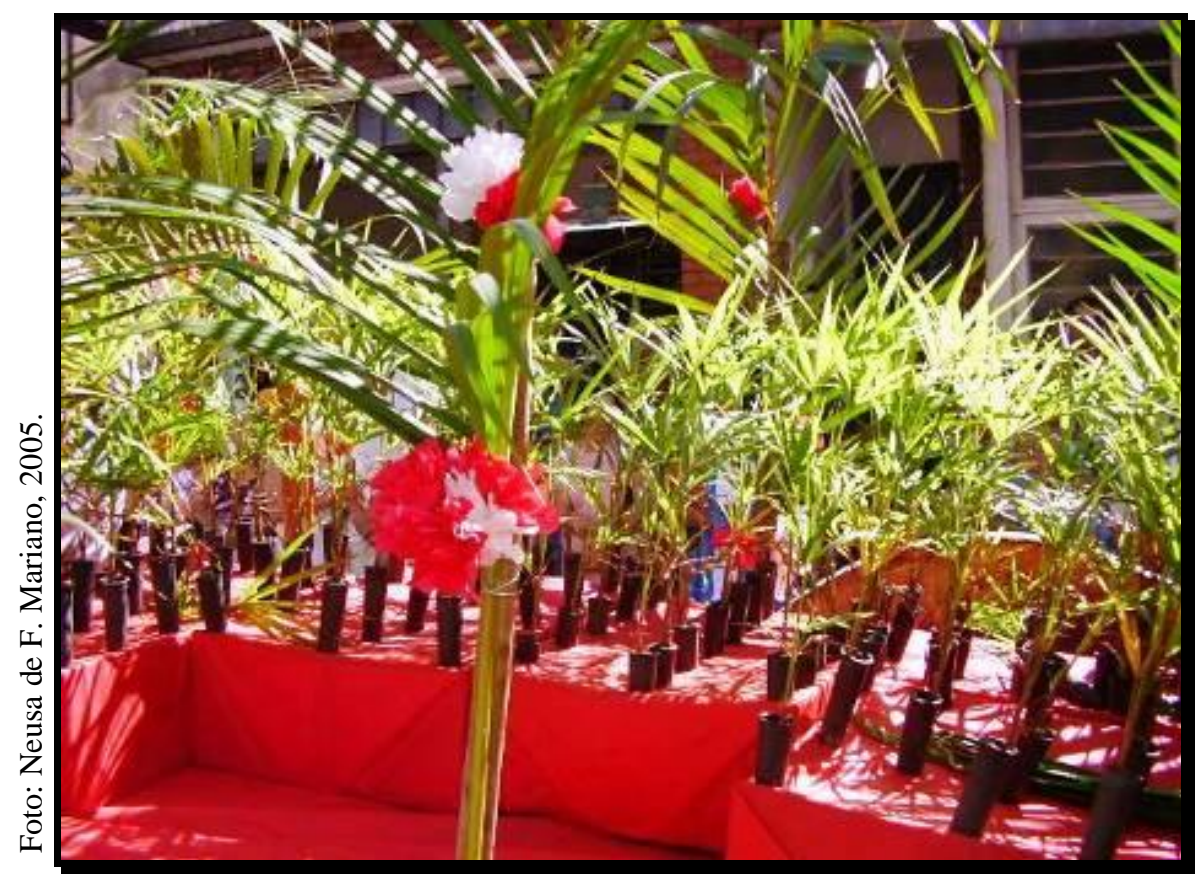

As mudas de palmito são alusivas àqueles trazidos pela população rural.

Foto 36.

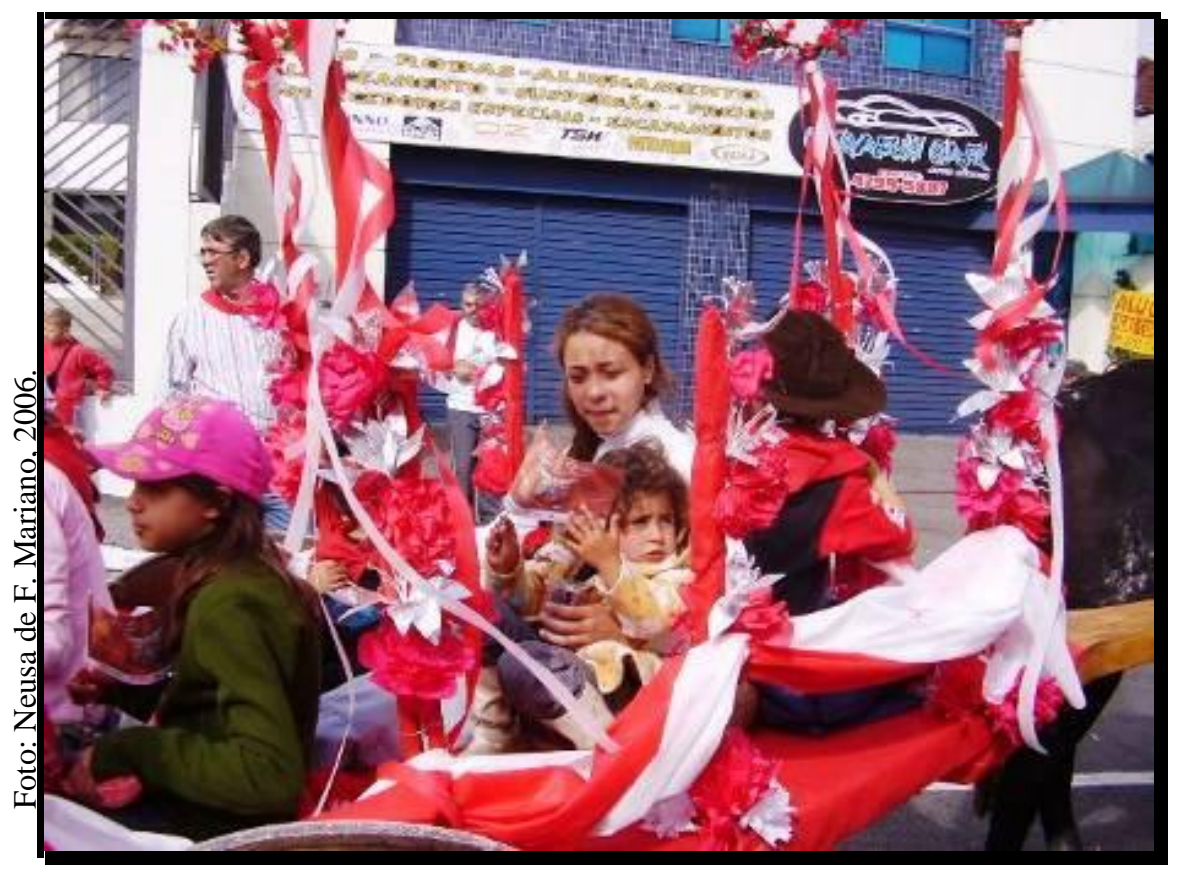

Crianças organizadas pelas escolas ou pelas paróquias participam da Entrada dos Palmitos dentro dos carros de bois.

\section{pdfMachine}

A pdf writer that produces quality PDF files with ease!

Produce quality PDF files in seconds and preserve the integrity of your original documents. Compatible across

nearly all Windows platforms, simply open the document you want to convert, click "print", select the

"Broadgun pdfMachine printer" and that's it! Get yours now! 
Foto 37.

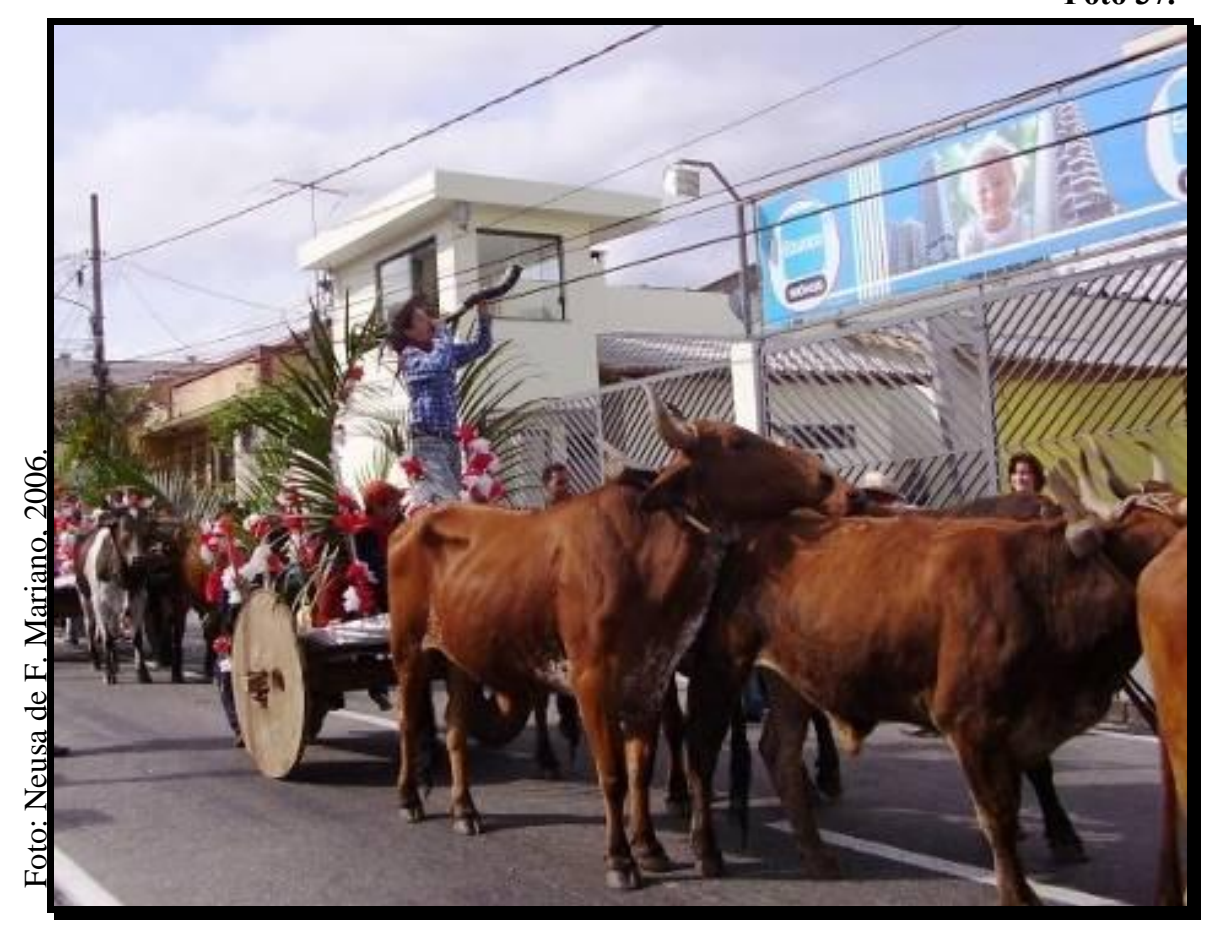

O boi do carro de bois não vai ser abatido, ele não vai ser usado para nada, ele só vai ser usado para carregar o carro dele. Então ele precisa ser treinado, precisa treinar ele todo dia, senão não anda: um vai pra lá, o outro vai pra cá.

Foto 38.

Airton

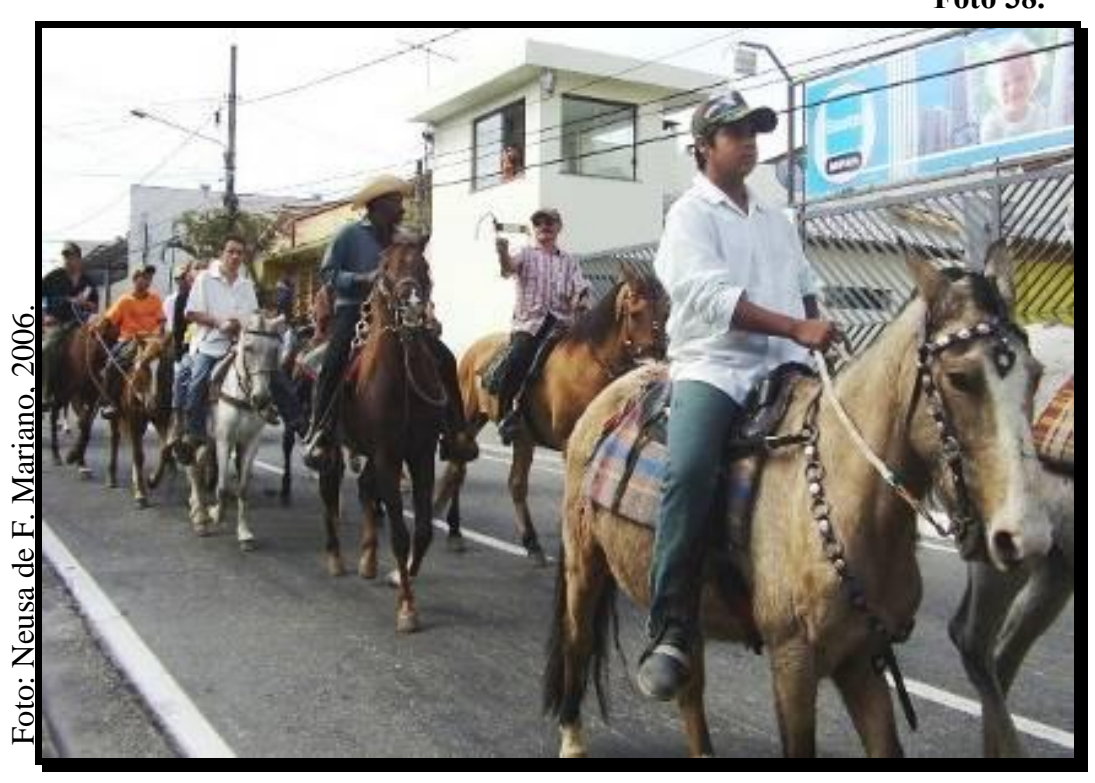

Tem muitos cavaleiros, mas é aquele negócio, são cavaleiros que fazem isso por hobby também. [...] A gente tem enfrentado este problema na Entrada dos Palmitos, de os cavaleiros não entenderem que a Entrada dos Palmitos é um cortejo folclórico de aspecto religioso.

Josemir

\section{pdfMachine}

\section{A pdf writer that produces quality PDF files with ease!}

Produce quality PDF files in seconds and preserve the integrity of your original documents. Compatible across nearly all Windows platforms, simply open the document you want to convert, click "print", select the

"Broadgun pdfMachine printer" and that's it! Get yours now! 
Foto 39.

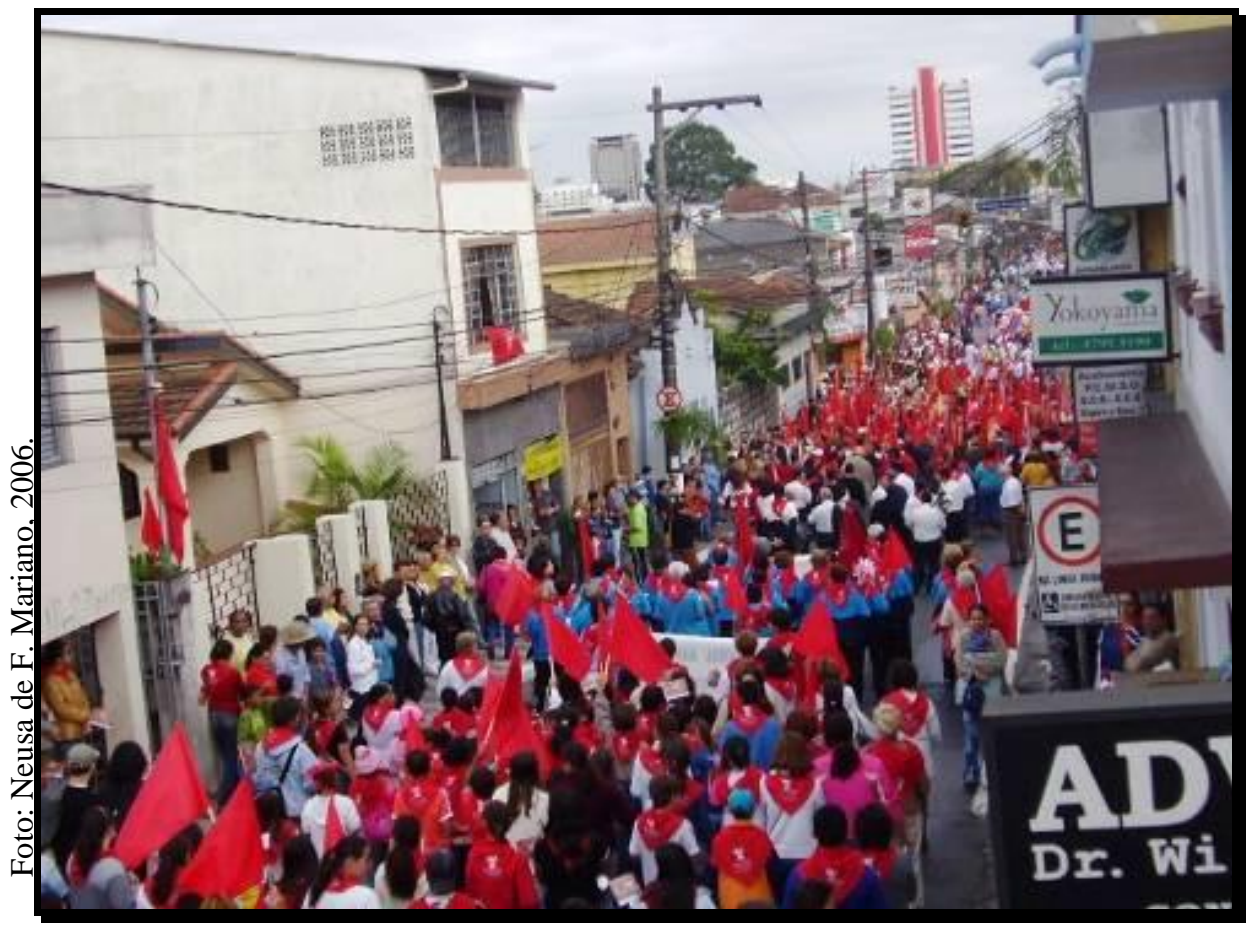

A Entrada dos Palmitos é marcante, é muito marcante.

Eu acho que quase cem por cento das pessoas esperam por esse momento.

Vicente

Foto 40.

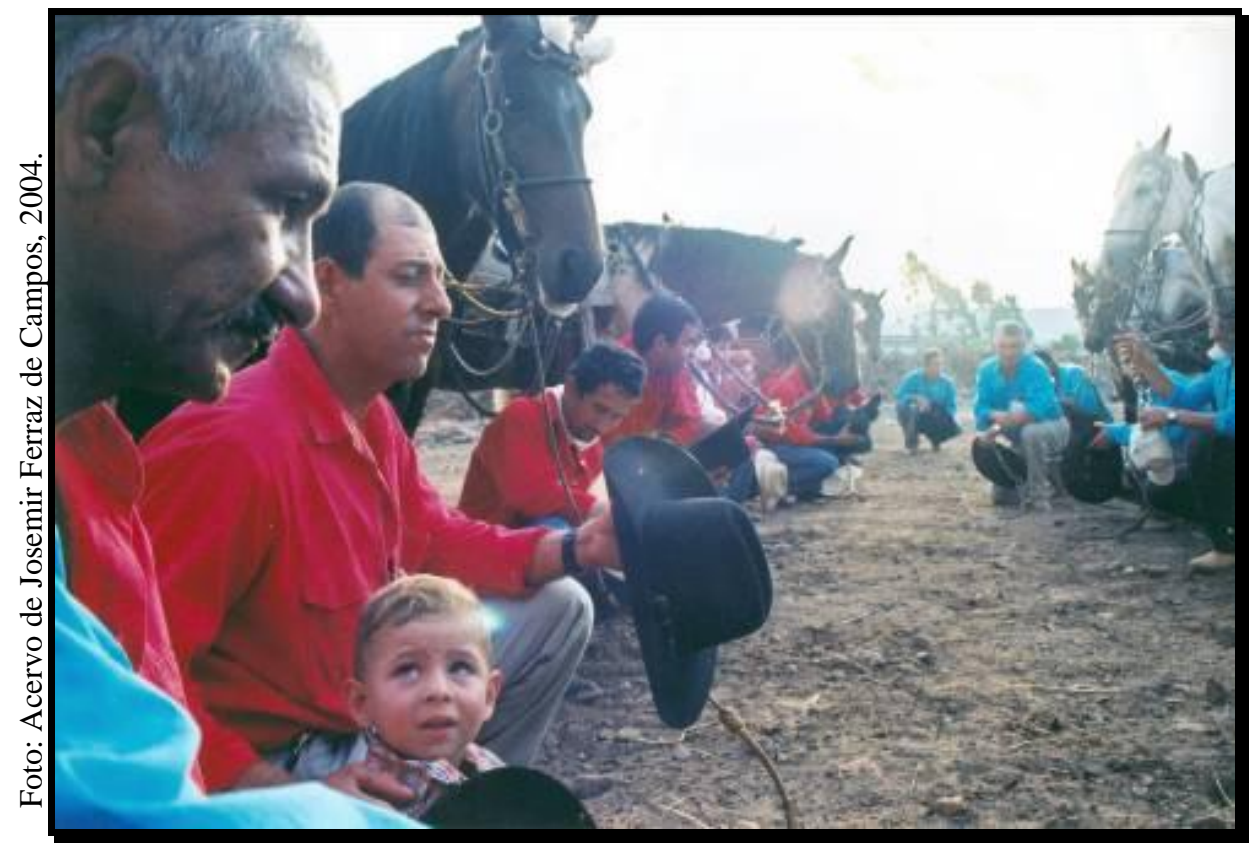

Cavalhada de Guararema, em apresentação após a Entrada dos Palmitos.

\section{pdfMachine}

A pdf writer that produces quality PDF files with ease!

Produce quality PDF files in seconds and preserve the integrity of your original documents. Compatible across

nearly all Windows platforms, simply open the document you want to convert, click "print", select the

"Broadgun pdfMachine printer" and that's it! Get yours now! 
Foto 41.

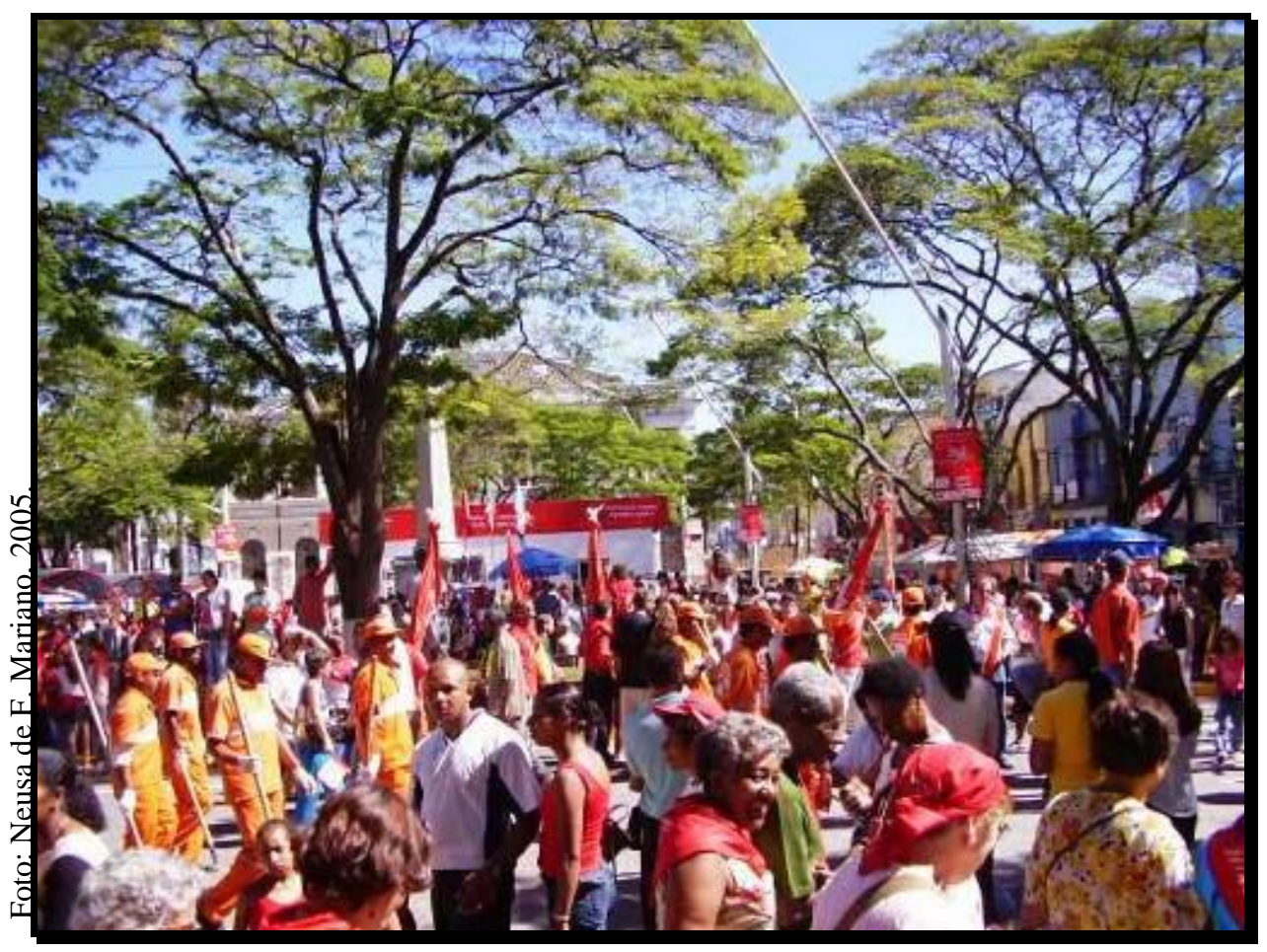

A Entrada dos Palmitos termina em frente ao Império do Divino. Garis se juntam à população que participou do cortejo.

Foto 42.

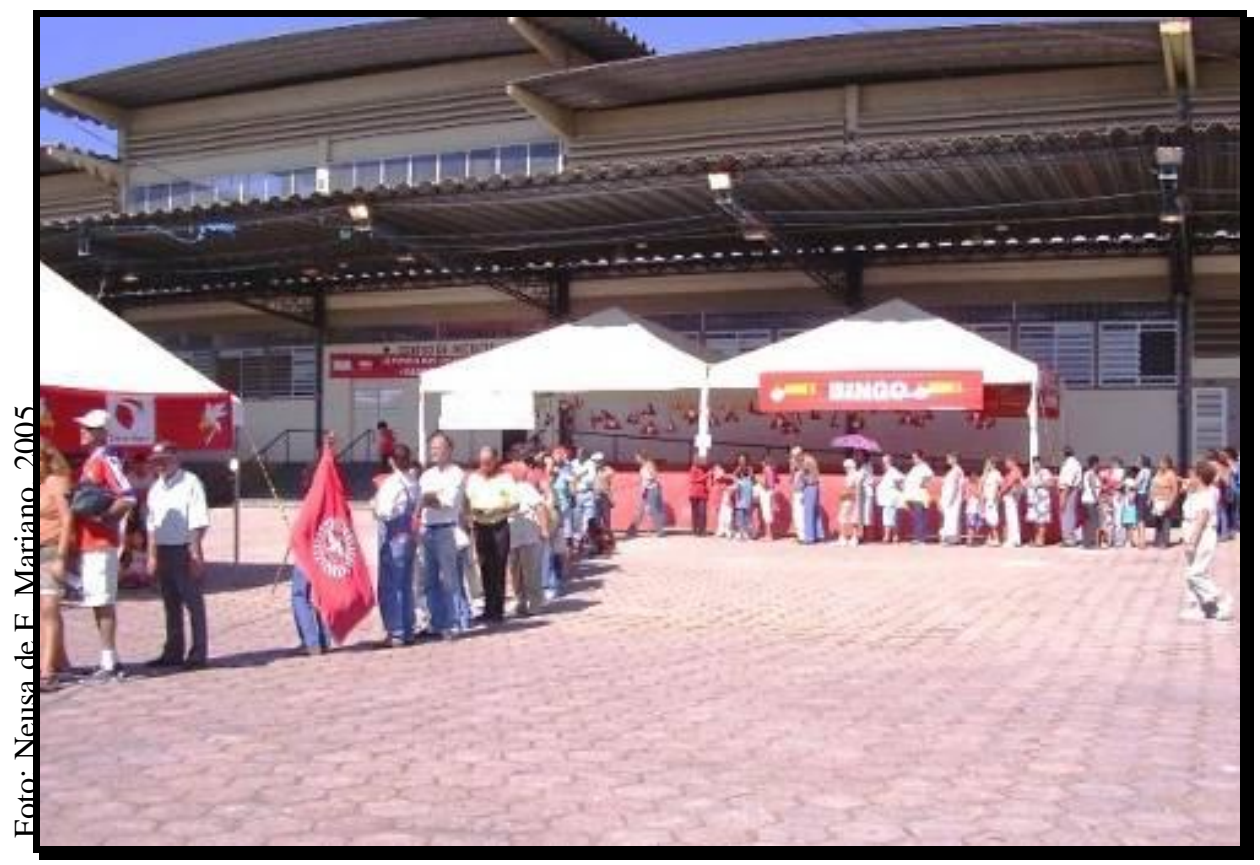

As pessoas seguem para o CIP, onde o "Afogadão" é distribuído aos que enfrentaram fila imensa, sob sol forte.

\section{pdfMachine}

A pdf writer that produces quality PDF files with ease!

Produce quality PDF files in seconds and preserve the integrity of your original documents. Compatible across nearly all Windows platforms, simply open the document you want to convert, click "print", select the "Broadgun pdfMachine printer" and that's it! Get yours now! 
O sábado, véspera de Pentecostes, é o dia que mais tem atividades na Festa do Divino de Mogi. Após a distribuição do Afogado, inicia-se, a partir de 17:00h, o ritual de levantamento do Mastro, uma responsabilidade específica dos Capitães de Mastro. Em procissão ${ }^{139}$ seguem os Lanterneiros, os "grupos folclóricos" e os devotos. Fiéis carregam o Mastro à frente dos Festeiros e Capitães de Mastro que levam a Bandeira do Divino (hoje estampada em uma placa de acrílico - Foto 43). Ao chegar em frente à Catedral de Santana, o Padre asperge a Bandeira do Divino antes de ser colocada no Mastro, após o quê é servido o licor "rosa-sol" ${ }^{140}$. Talvez as baixas temperaturas de maio e junho tenham contribuído para a distribuição do licor, pois como a bebida é alcoólica, confortaria as pessoas no frio da tarde.

A Bandeira no alto do Mastro anuncia que o Espírito Santo está por chegar, ao som dos grupos de Congada e Moçambique, que tocam e dançam sob o Mastro (Foto 44).

${ }^{139}$ A procissão, que partia da residência dos Capitães de Mastro, geralmente tem saído da casa de Dona Amália (falecida em 2006), provavelmente por se localizar próxima à Catedral de Santana.

140 "A bebida típica é feita com pinga, bastante cravo, canela, erva doce, casca de limão e noz moscada. Depois de fazer uma calda com os ingredientes, se mistura um pouco de anilina vermelha, até que a bebida adquira a cor rosada" (http://www.festadodivino.org.br - acesso em março de $20 \cap 7)$

\section{pdfMachine}

A pdf writer that produces quality PDF files with ease!

Produce quality PDF files in seconds and preserve the integrity of your original documents. Compatible across nearly all Windows platforms, simply open the document you want to convert, click "print", select the "Broadgun pdfMachine printer" and that's it! Get yours now! 


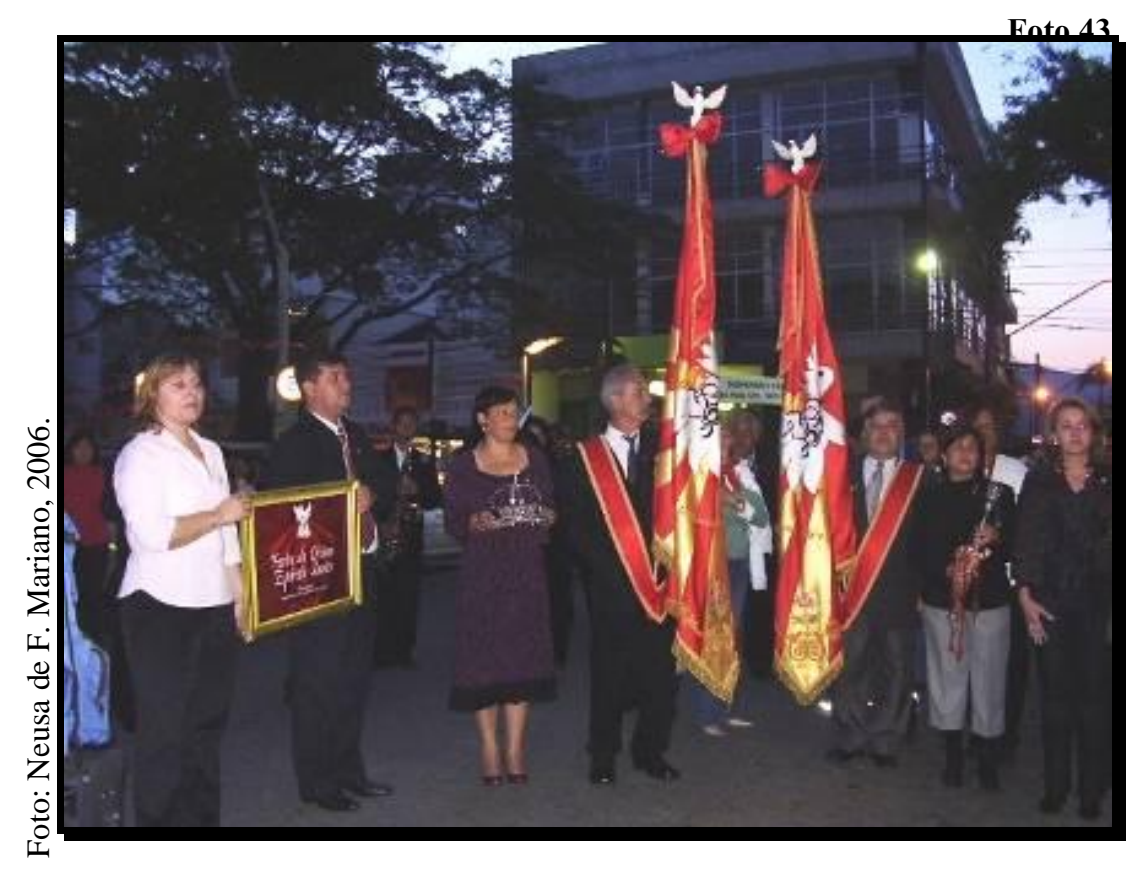

Nós saímos em procissão e nós viemos para a Catedral de Santana, onde é feito o levantamento do Mastro. [...] Essa é a parte em que o capitão tem à frente [...]. Então aquela bandeira no Mastro imenso, a gente precisa de muitas pessoas para carregar. [...] Então foi um momento muito bonito também.

Mônica

Foto 44.

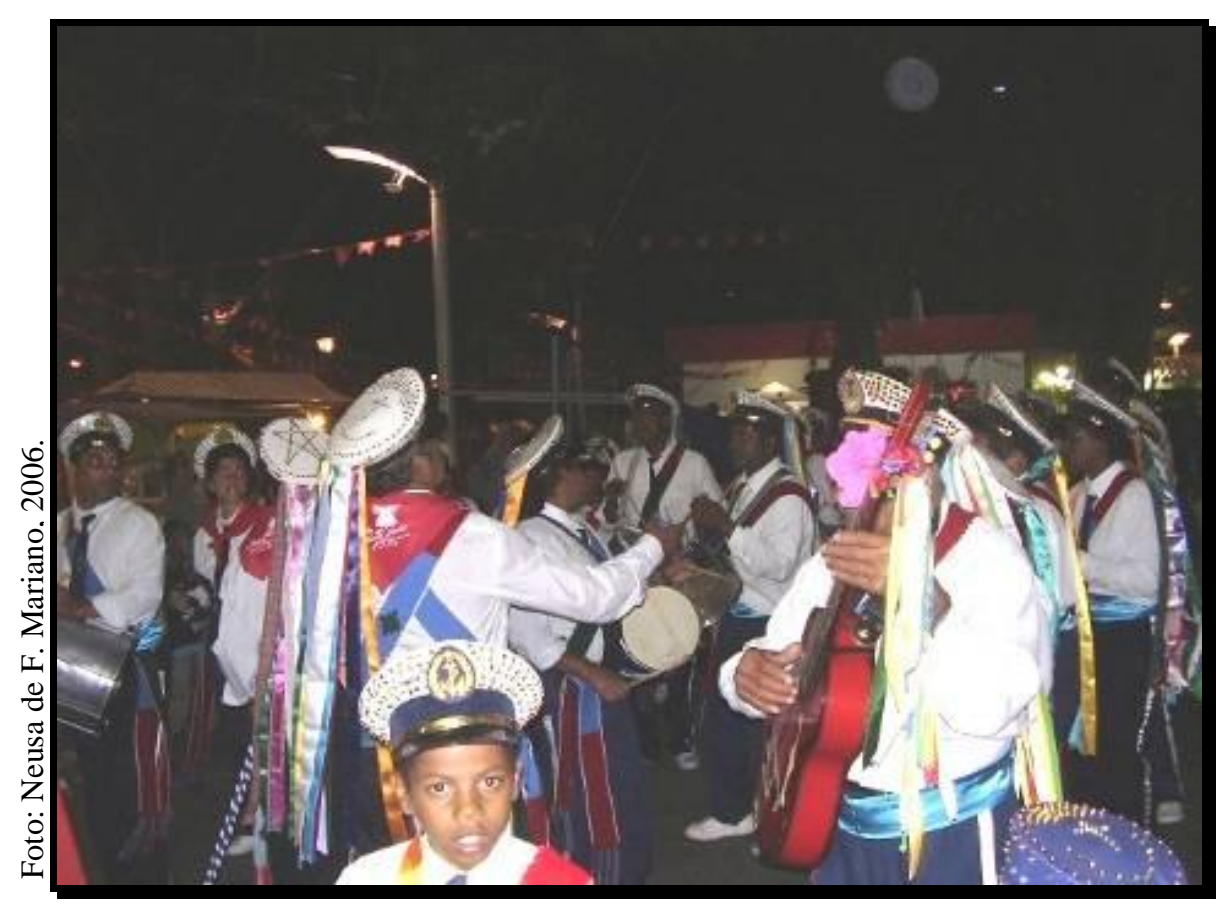

Grupos de Congada e Moçambique dançam ao pé do Mastro com a Bandeira do Divino no alto. Na foto, está o Grupo de Congada de Nossa Senhora do Rosário.

\section{pdfMachine}

\section{A pdf writer that produces quality PDF files with ease!}

Produce quality PDF files in seconds and preserve the integrity of your original documents. Compatible across nearly all Windows platforms, simply open the document you want to convert, click "print", select the "Broadgun pdfMachine printer" and that's it! Get yours now! 


\subsubsection{O Divino passeia com seus devotos}

Nessa última Festa do Divino agora... aquela Procissão do Divino foi

muito bonita. Assistiu?

Georgina

A Procissão de Pentecostes, o "ponto alto" da parte religiosa da Festa do Divino, é realizada no domingo a partir das 16:00h. Participam dela os grupos de Congada e Moçambique, as Irmandades de São Benedito, do Sagrado Coração de Jesus, de Santana e do Santíssimo Sacramento, além da Venerável Ordem Terceira do Carmo; na seqüência vêm as Rezadeiras, uniformizadas com saia e casaco azuis, carregando os pedidos dos devotos dentro de caixas fechadas. Seguem-se o Bispo Diocesano e os padres; o Imperador e a Imperatriz (casal de crianças); os Festeiros e Capitães de Mastro; os casais de ex-Festeiros e ex-Capitães de Mastro; o andor do Divino (representado pela imagem de uma Pomba Branca), ricamente decorado e conduzido pelos rapazes do Tiro de Guerra; a Banda Santa Cecília e os devotos em geral ${ }^{141}$. (Fotos 45-54).

Geralmente os "grupos folclóricos" abriam a Procissão, mas em 2005 foi diferente. Eles se apresentaram depois do Andor do Divino e, em 2006, fechavam o cortejo, variação que depende não só dos organizadores da Procissão, mas também do Bispo. No percurso da Procissão são montados sete altares do Divino, um de cada cor, representando os dons do Divino Espírito Santo. Ali, a procissão pára, reza-se a oração do Divino Espírito Santo, fazse uma referência ao dom, e uma pomba branca que estava presa em uma gaiola, é solta. A procissão parte da Catedral de Santana, passa pelas igrejas do Carmo e de São Benedito, segue pela rua Dr. Deodato Wertheimer onde havia a igreja de Nossa Senhora do Rosário ${ }^{142}$, demolida em 1966, e termina na Catedral de Santana (Mapa 8).

${ }^{141}$ Conforme observado durante a Festa do Divino de Mogi em 2004.

${ }^{142}$ Hoje há uma imagem da igreja de Nossa Senhora do Rosário em um painel, suspenso em frente an Hotel Binder onde se localizava a ioreia 


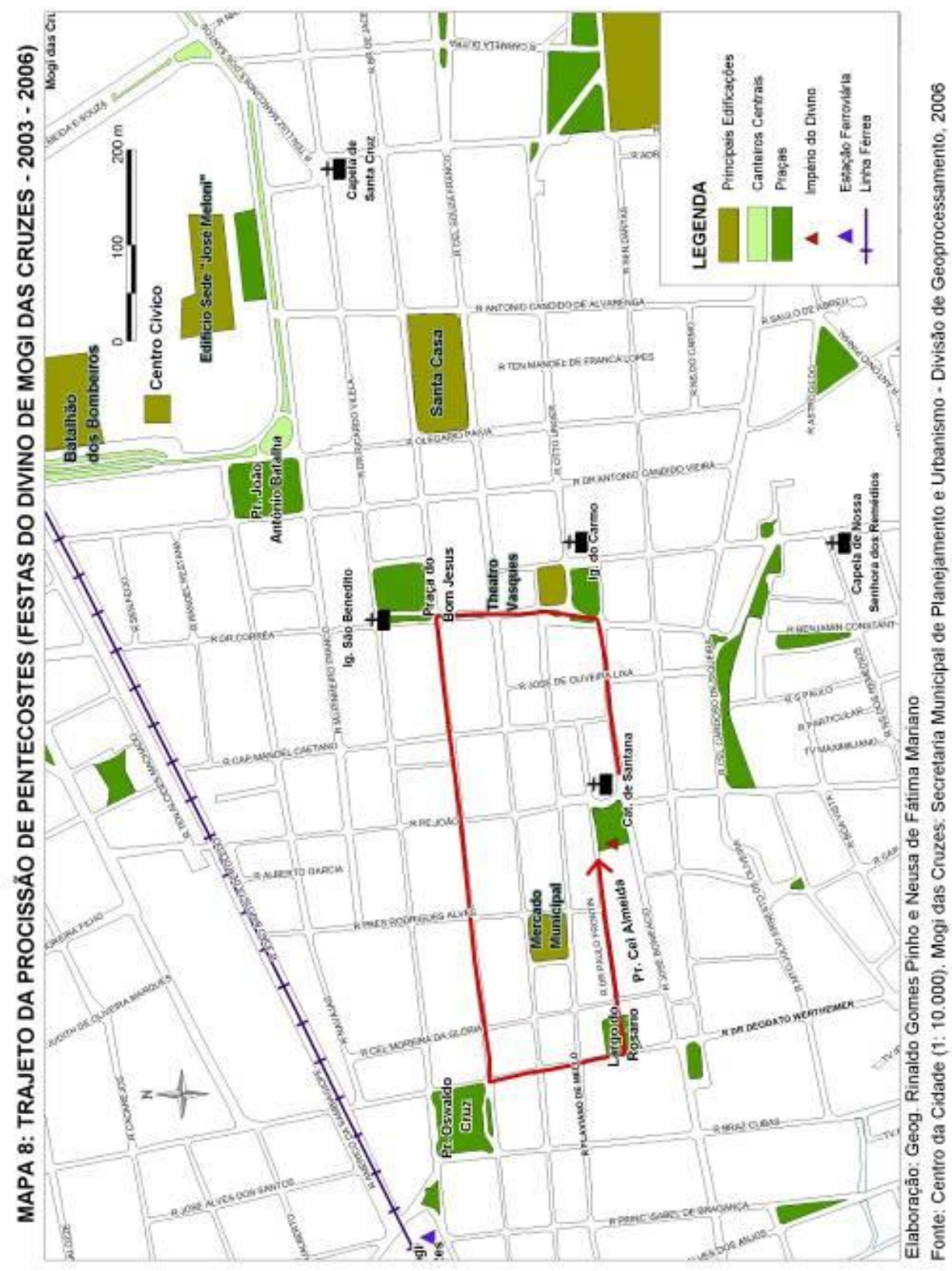

pdfMachine

A pdf writer that produces quality PDF files with ease!

Produce quality PDF files in seconds and preserve the integrity of your original documents. Compatible across nearly all Windows platforms, simply open the document you want to convert, click "print", select the 
Foto 45.

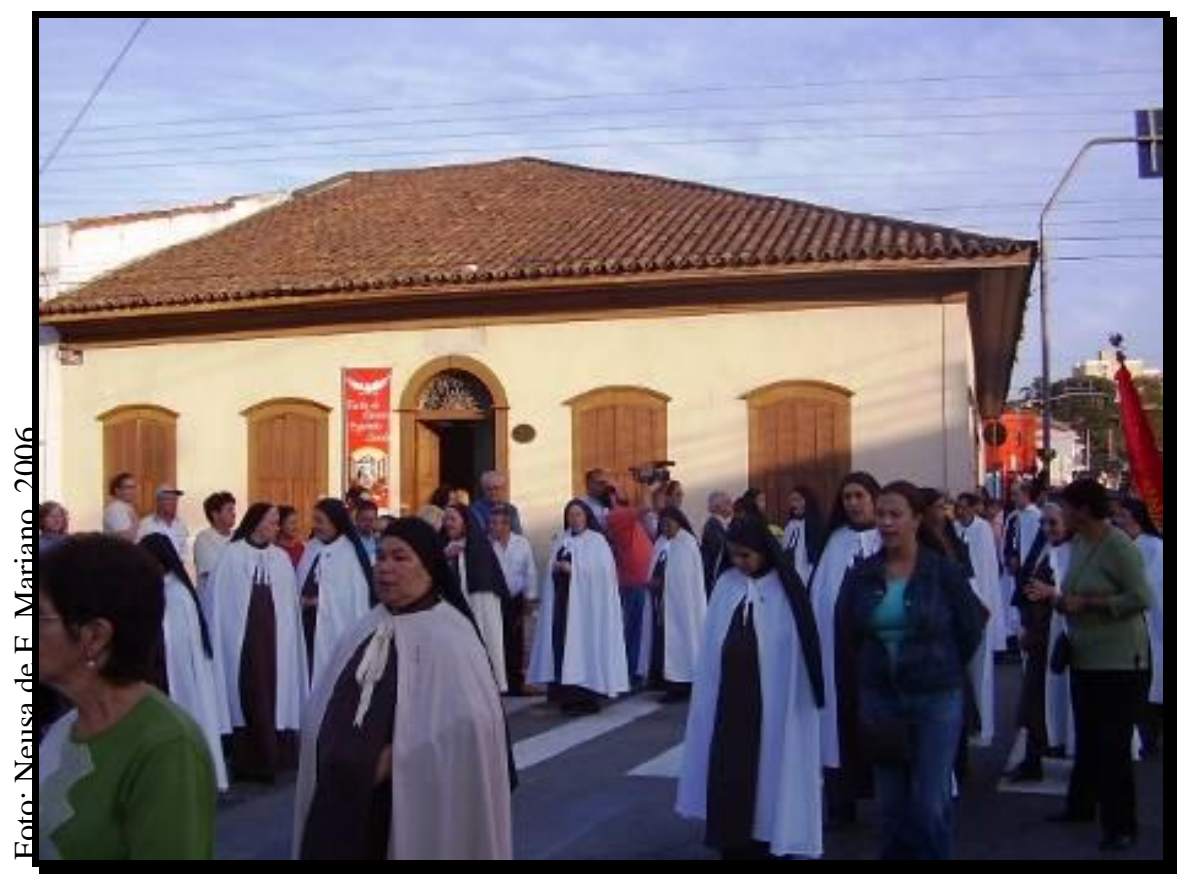

Irmãs Carmelitas saem da clausura para participar da Procissão de Pentecostes.

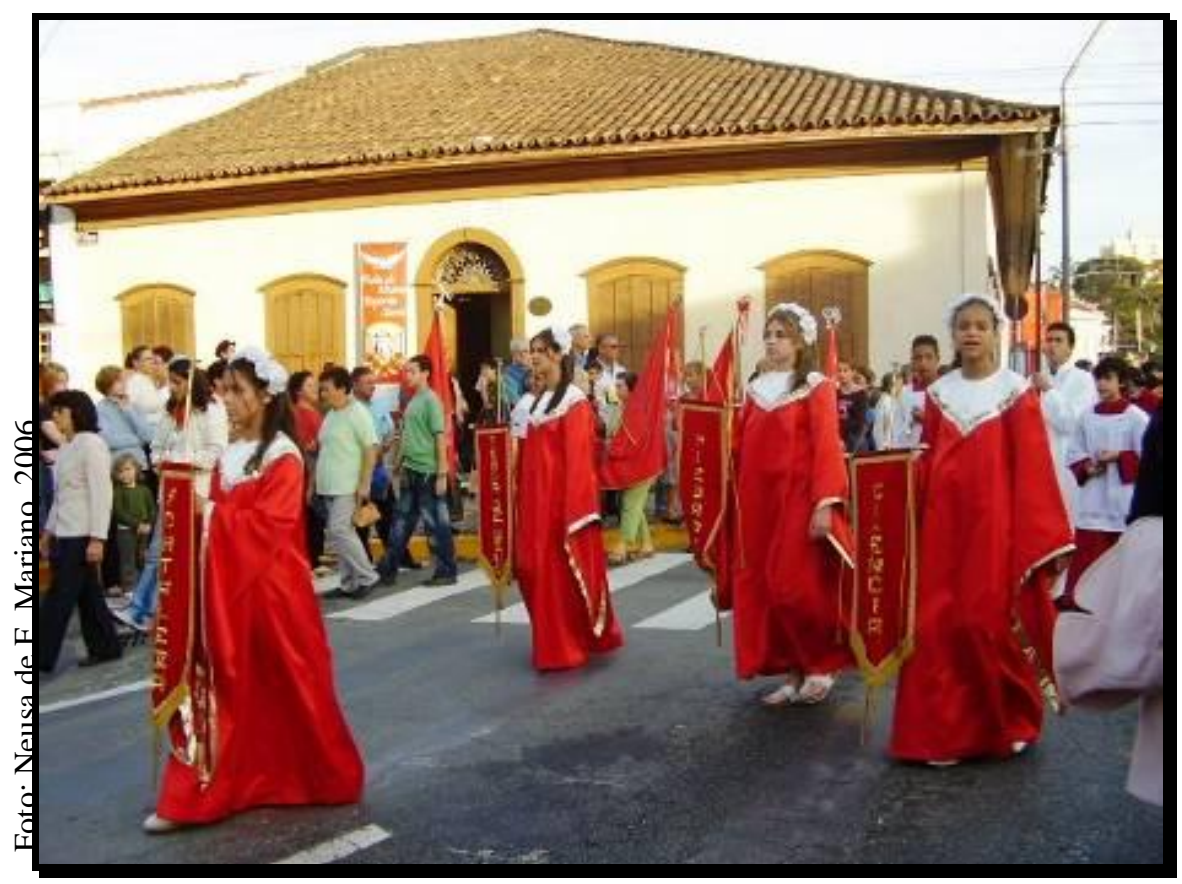

Foto 46.

Recrutar as meninas que saem vestidas com túnicas, levando os dons do Divino em pequenos estandartes, ou como anjos na Procissão de Pentecostes, é um trabalho que requer tempo, pois a partir de um primeiro contato, é preciso experimentar a roupa e fazer possíveis ajustes ${ }^{143}$.

${ }^{143}$ Conforme Salete, coordenadora de Ornamentação da Associação Pró-Festa do Divino Espírito Santo

\section{pdfMachine}

A pdf writer that produces quality PDF files with ease!

Produce quality PDF files in seconds and preserve the integrity of your original documents. Compatible across

nearly all Windows platforms, simply open the document you want to convert, click "print", select the

"Broadgun pdfMachine printer" and that's it! Get yours now! 


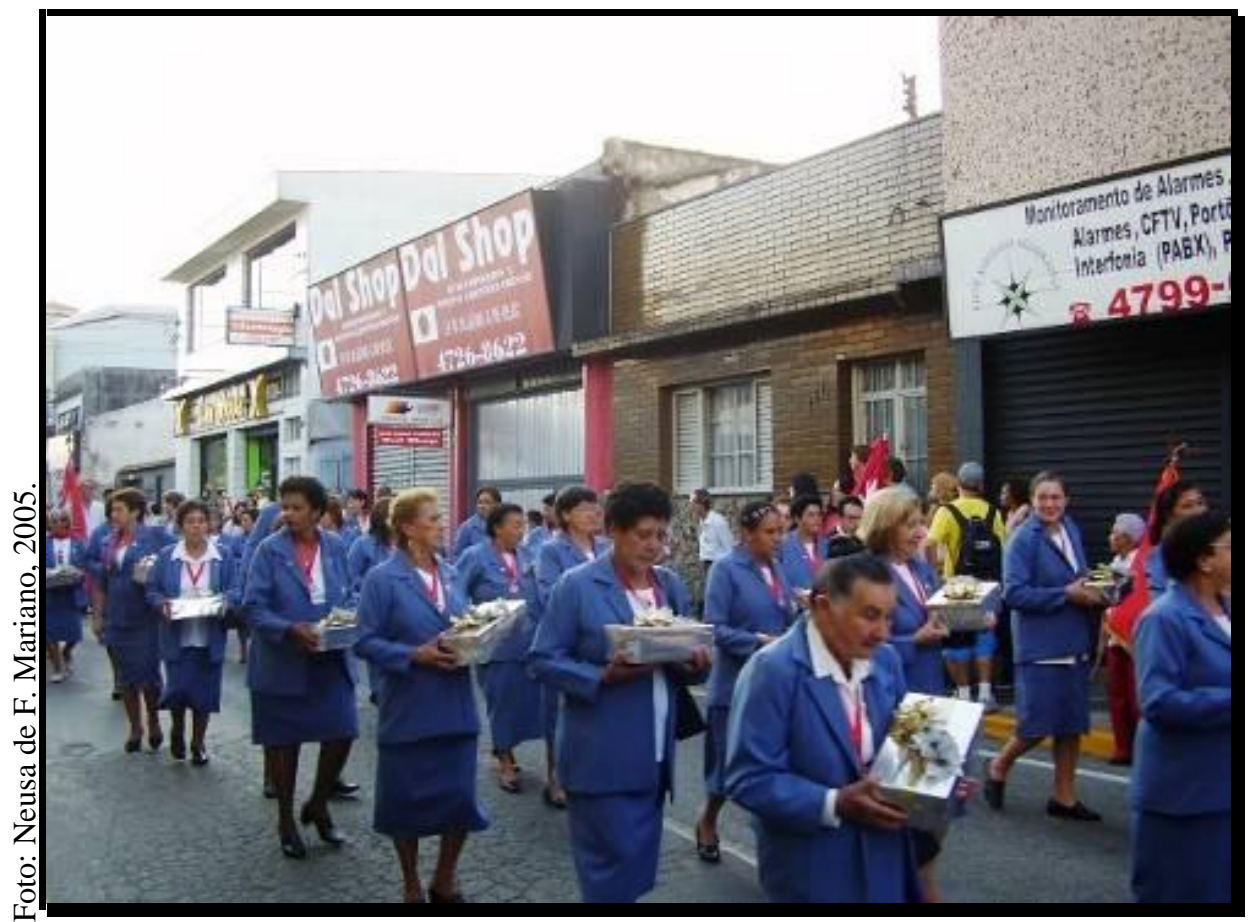

Agora não, é tudo registrado, tudo direitinho. Hoje nós temos uniforme das rezadeiras, saem na procissão, todas iguais. Nós temos a caixa de pedidos, todas iguais.

Dona Rita

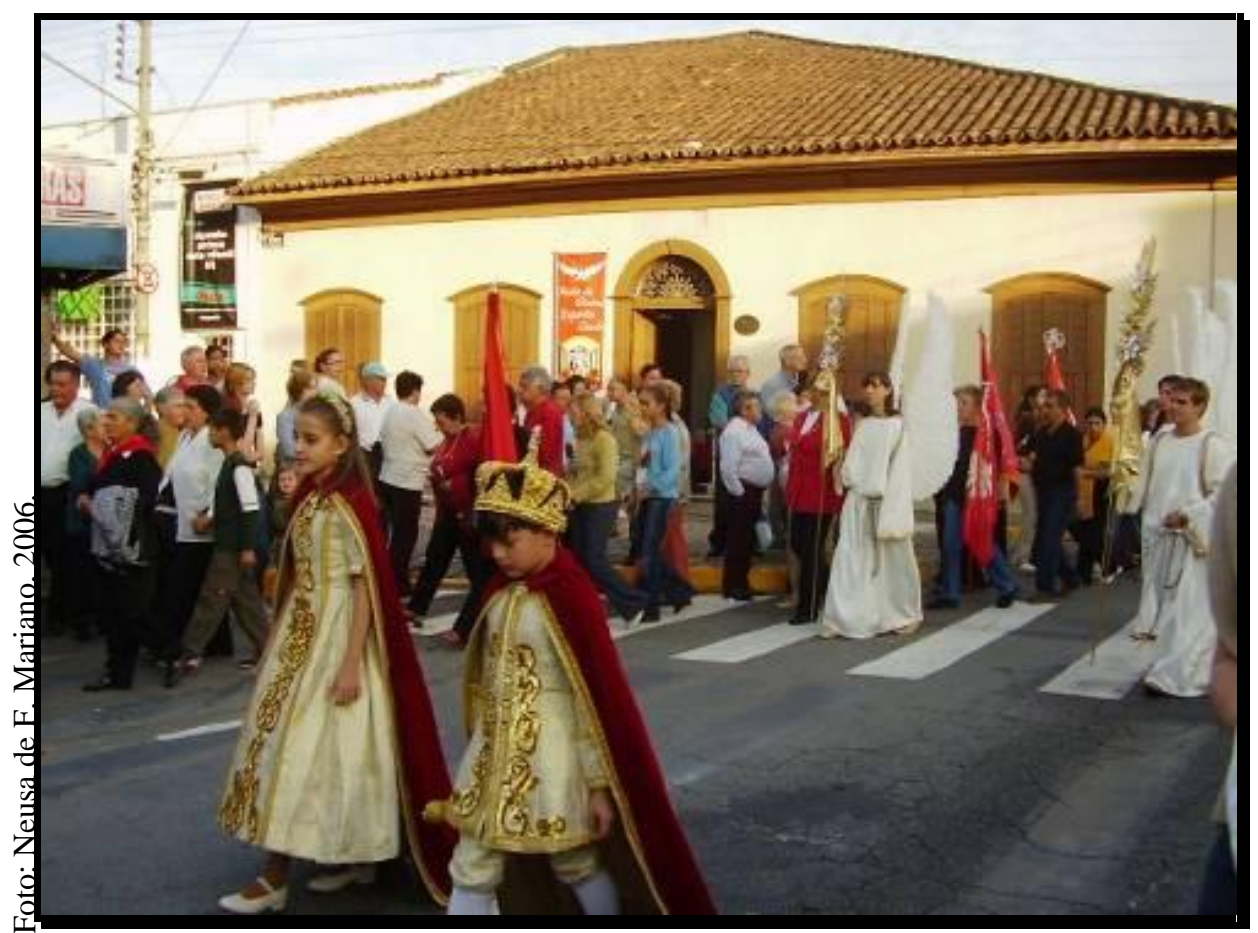

Foto 48.

Com seus trajes medievais, os Imperadores do Divino seguem na Procissão de Pentecostes.

\section{pdfMachine}

\section{A pdf writer that produces quality PDF files with ease!}

Produce quality PDF files in seconds and preserve the integrity of your original documents. Compatible across nearly all Windows platforms, simply open the document you want to convert, click "print", select the "Broadgun pdfMachine printer" and that's it! Get yours now! 
Foto 49.

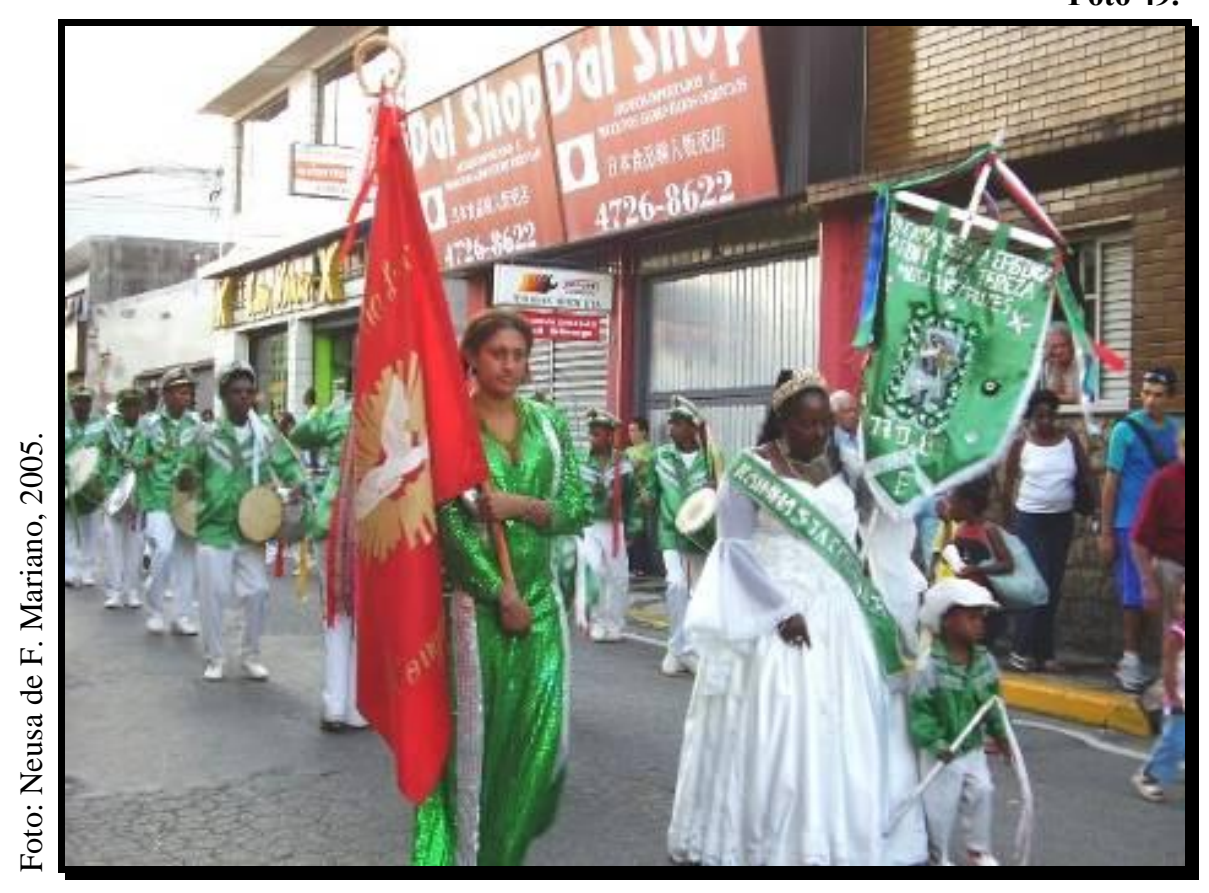

Antigamente tinha isso: o Festeiro ia na casa de cada grupo folclórico. Vinha o Festeiro e o Capitão de Mastro. [...]. Agora não! [...] Quando você vai conhecer o Festeiro, que às vezes não dá tempo, é muita correria, é na hora que está chegando o Divino, que eles estão chegando com a Coroa...

Capitã Gislaine da Congada de Santa Efigênia

Foto 50.

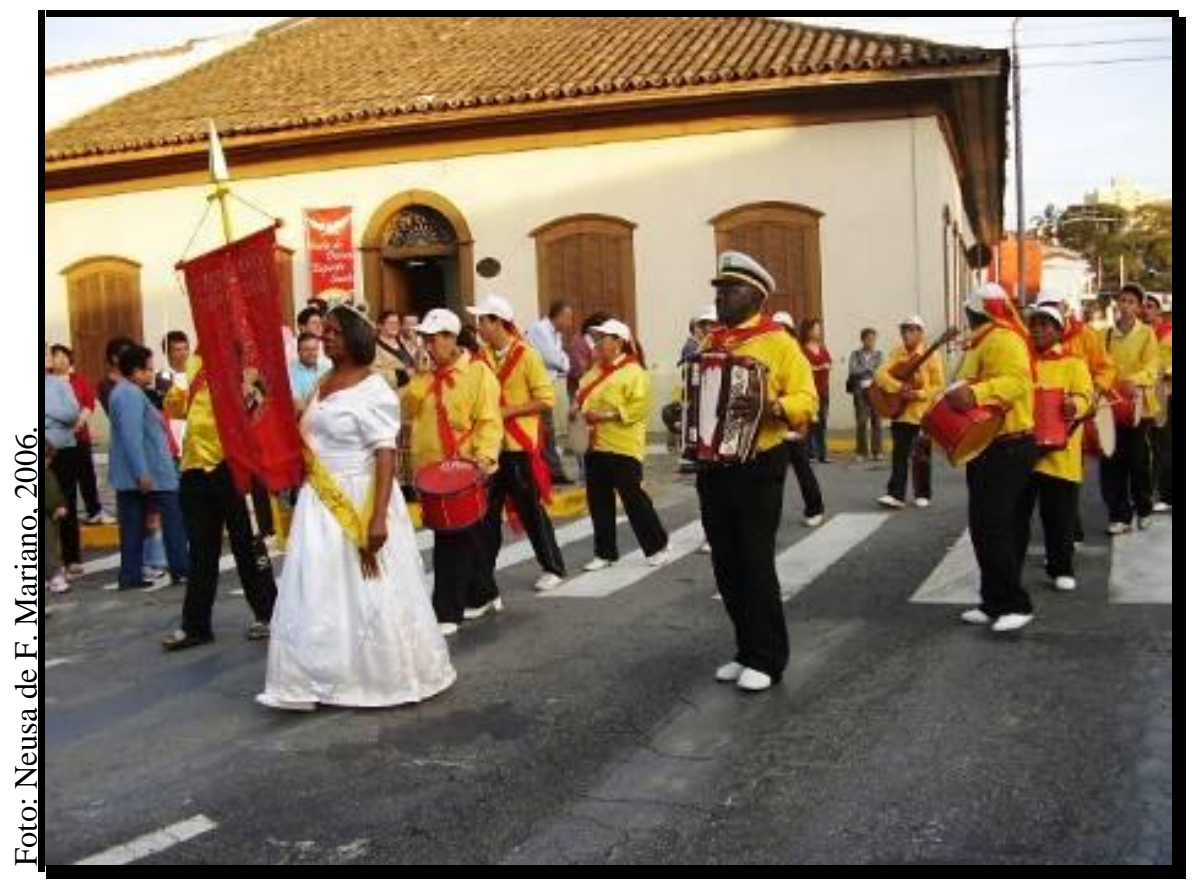

[Na época dos escravos] fizeram um sorteio, chamaram o dono da Congada e sortearam São Benedito, [para padroeiro do grupo] e colocar $o$ Santo na bandeira. Então meu avô falava que não podia ser outro santo, a minha é São Benedito.

Capitão Chico Preto da Congada de São Benedito

\section{pdfMachine}

\section{A pdf writer that produces quality PDF files with ease!}

Produce quality PDF files in seconds and preserve the integrity of your original documents. Compatible across nearly all Windows platforms, simply open the document you want to convert, click "print", select the 
Foto 51.

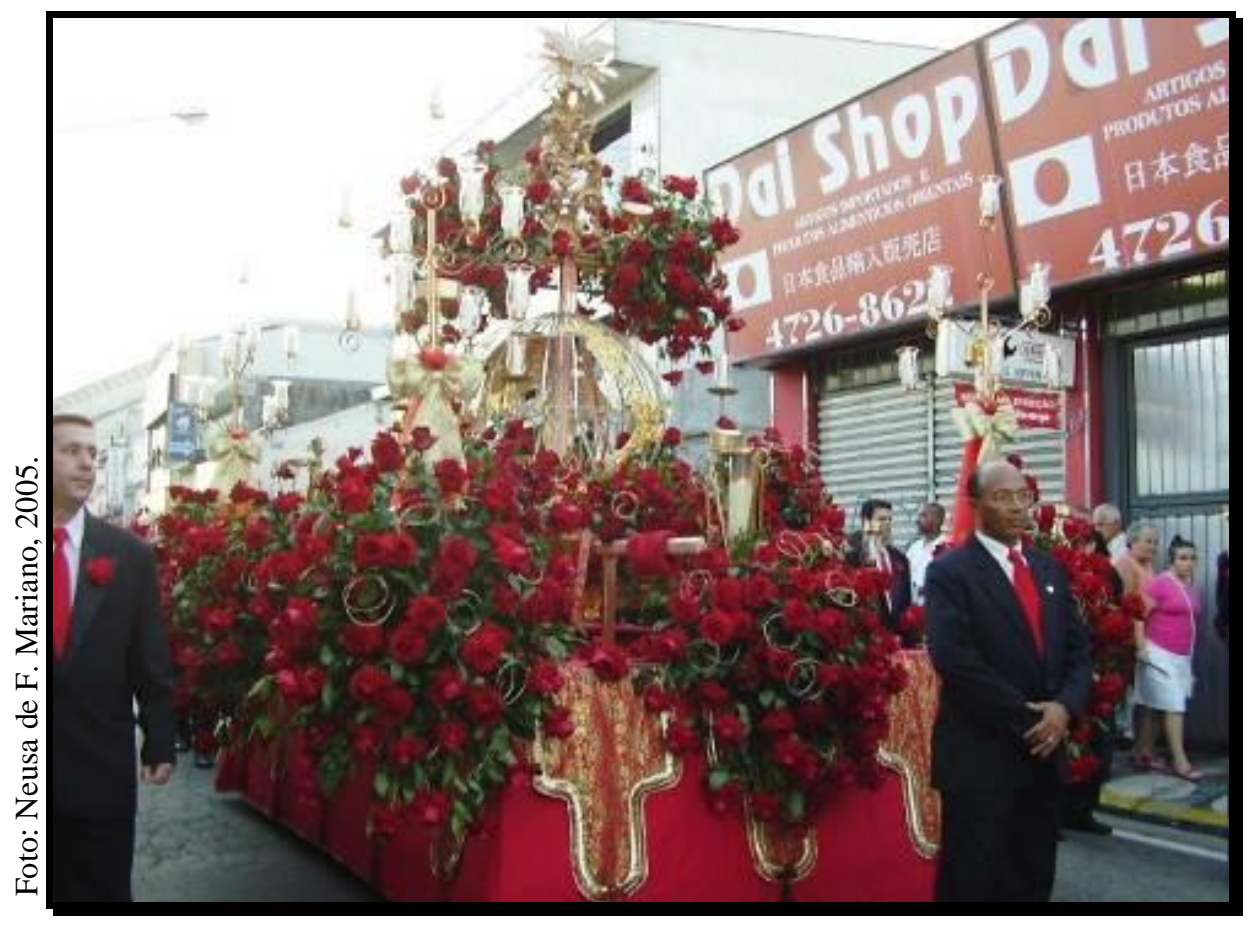

Andor do Espírito Santo, representado por uma Pomba Branca, que segue, com os devotos, na Procissão de Pentecostes cercado de seguranças.

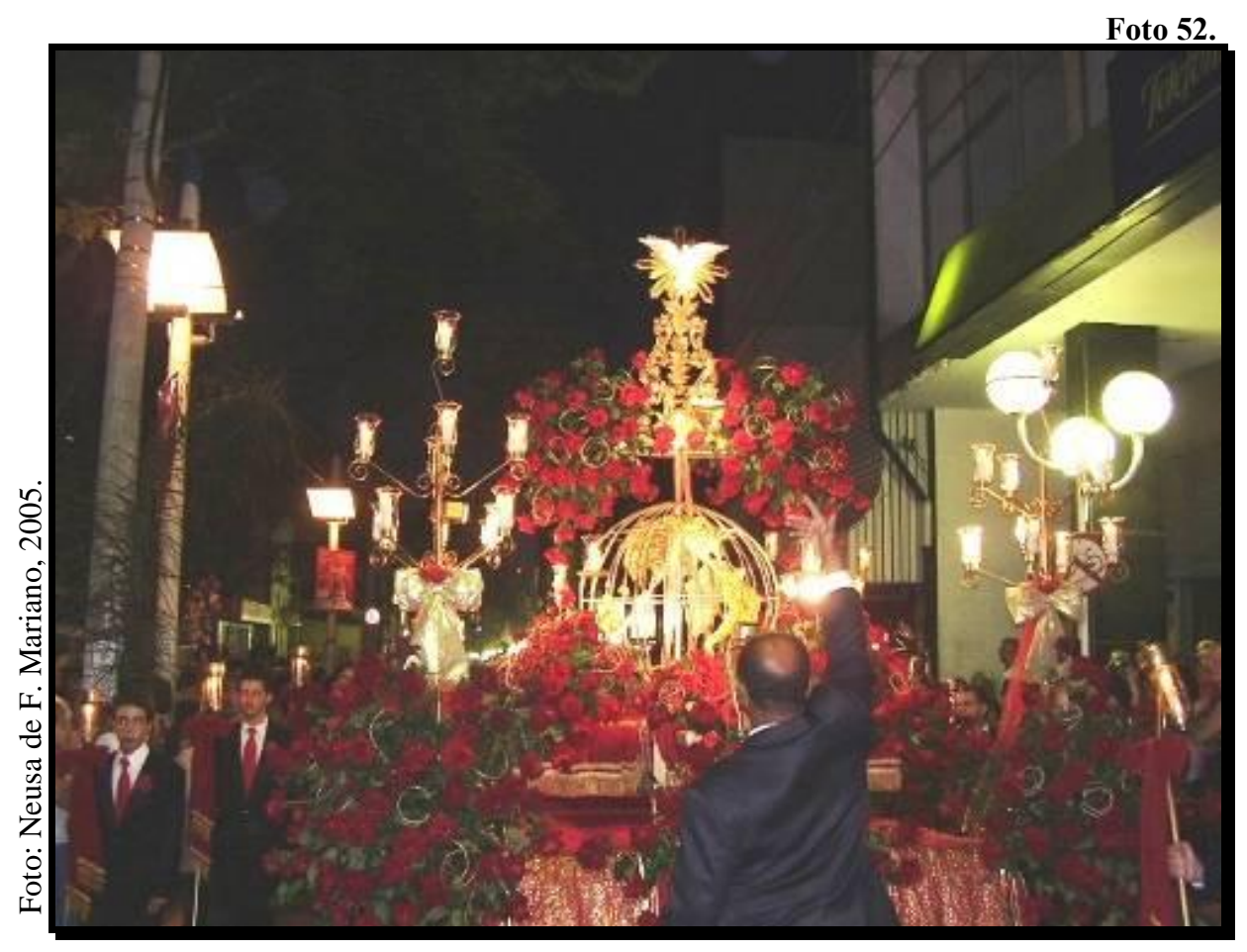

\section{pdfMachine}

A pdf writer that produces quality PDF files with ease!

Produce quality PDF files in seconds and preserve the integrity of your original documents. Compatible across nearly all Windows platforms, simply open the document you want to convert, click "print", select the "Broadgun pdfMachine printer" and that's it! Get yours now! 
Foto 53.

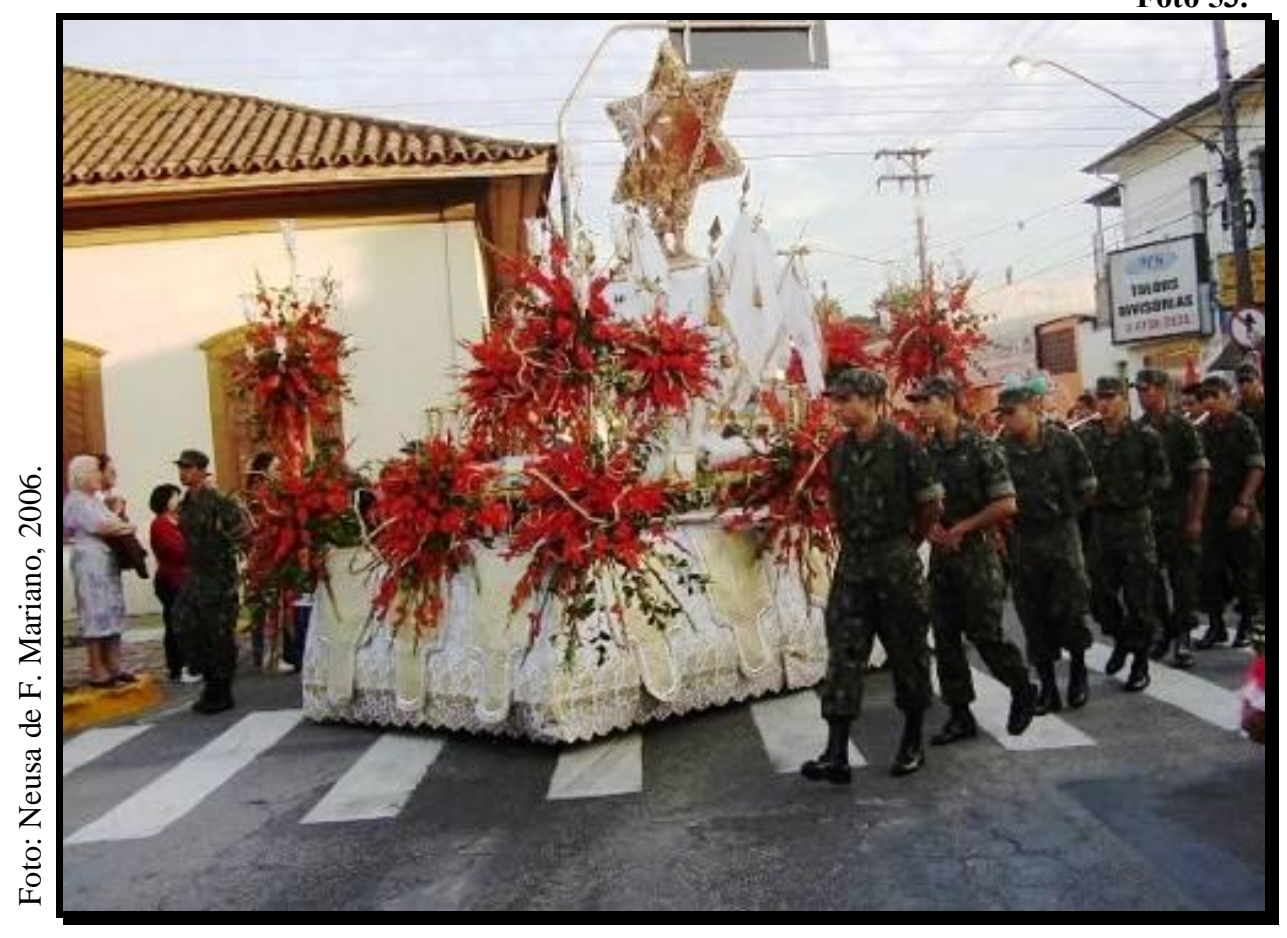

A cada ano, o Andor do Divino é superado em beleza e luxo, sempre recebido com aplausos pela população que fica nas calçadas das ruas da cidade, à sua espera.

Foto 54.

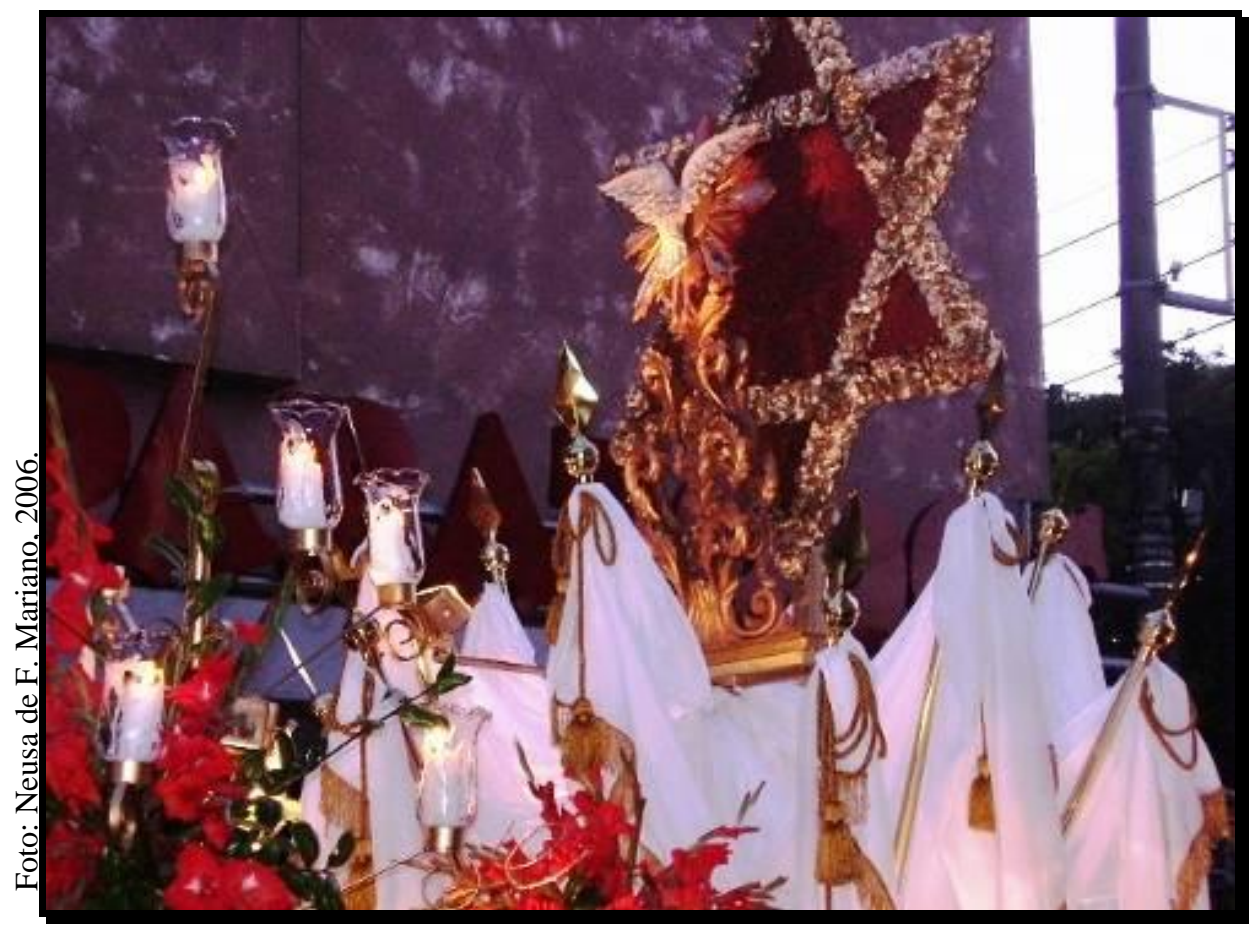

\section{pdfMachine}

A pdf writer that produces quality PDF files with ease!

Produce quality PDF files in seconds and preserve the integrity of your original documents. Compatible across nearly all Windows platforms, simply open the document you want to convert, click "print", select the "Broadgun pdfMachine printer" and that's it! Get yours now! 
A partir da rua Dr. Deodato Wertheimer, a Procissão passa sobre o Tapete Ornamental $^{144}$ confeccionado, pela manhã, por estudantes e membros de várias instituições como a APAE - Associação de Pais e Amigos dos Excepcionais - e algumas Paróquias. Enquanto aguardam a Procissão de Pentecostes, as pessoas podem apreciar o Tapete, feito com pó de quartzo colorido - um quadro superando o outro em beleza e delicadeza (Fotos 55 e 56). Desde 1994, o Tapete Ornamental foi incorporado às atividades da Festa do Divino de Mogi das Cruzes, mesmo sendo uma tradição da Procissão de Corpus Christi, aliás, não praticada na cidade. Explica o Sr. Mathias Tomasulo, coordenador do Tapete desde então, que o convite partiu do Festeiro da época, Saul Grinberg ${ }^{145}$, com o objetivo de “incrementar” as festividades do Divino Espírito Santo.

A extensão do Tapete nas ruas do centro da cidade passou de $100 \mathrm{~m}$ nos primeiros anos para 500m atualmente, e é confeccionado conforme explica o Sr. Mathias:

Na Festa do Divino, o Divino tem sete dons; obrigatoriamente, nós colocamos os sete dons. Cada Festeiro tem um logotipo [da Festa do ano] a gente coloca o logotipo do Festeiro. Nós dividimos o tapete assim: dons do Divino, parte folclórica, e parte de assunto do momento da CNBB [Conferência Nacional dos Bispos do Brasil] [...] O primeiro tapete que eu fiz, nós unimos quadro a quadro. Quadro com quadro. Ficou pequeno! Ficou curto! O quê que eu fiz? Eu fiz assim: eu fiz uma passadeira, para esticar o tapete. Tem o quadro, e tem uma passadeira. Seis, sete, oito metros, outro quadro. Seis, sete, oito metros, outro quadro. Então, o tapete esticou. E pega o calçadão da Paulo Frontin, o calçadão da Doutor Deodato, passando pelo meio do largo do Rosário. Chega a dar uns quinhentos metros. E nós fazemos também, um quadro em frente à Catedral, um quadro grande. É assim, o desenho da passadeira sou eu que faço. Eu faço o desenho, a gente dá o material, tudo - a Festa dá o material. E cada quadro é sorteado o tema, vamos dizer, os dons do Divino: piedade, fortaleza, temor a Deus... - é sorteado. A escola que pega, bola um desenho, baseado no tema.

${ }^{144}$ Em 2006, alguns dias antes do início da Festa do Divino, o Tapete Ornamental ganhou corredores do shopping de Mogi das Cruzes, confeccionado com pó de quartzo, pelos alunos da Universidade Braz Cubas e da UNAI (Universidade Aberta à Integração - voltada para idosos), conforme o Diário de Mogi (23/05/2006).

145 Reitor da URC Saul Grinhero foi um dos fundadores da Ascaciacão Pró-Divino 
Foto 55.

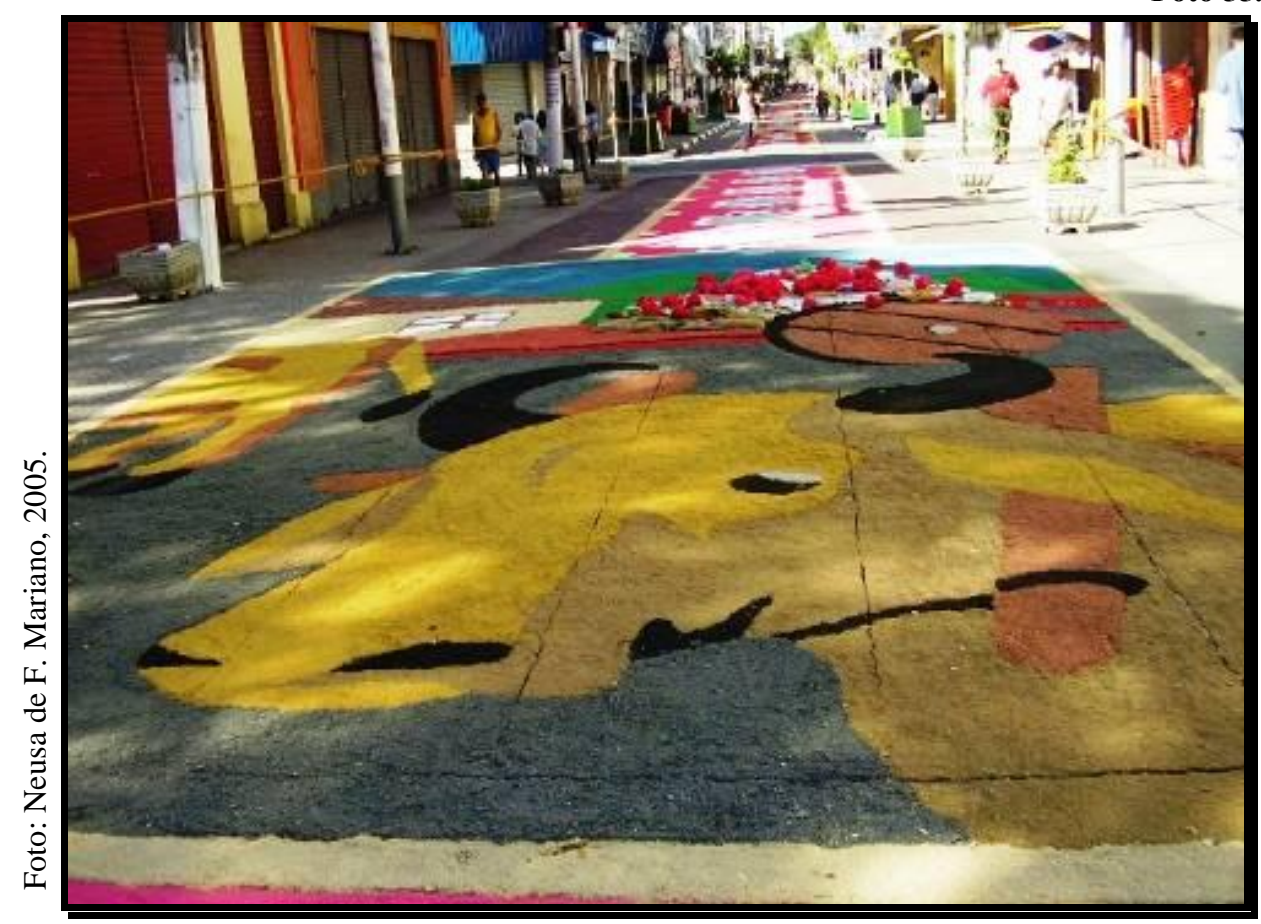

Foto 56.

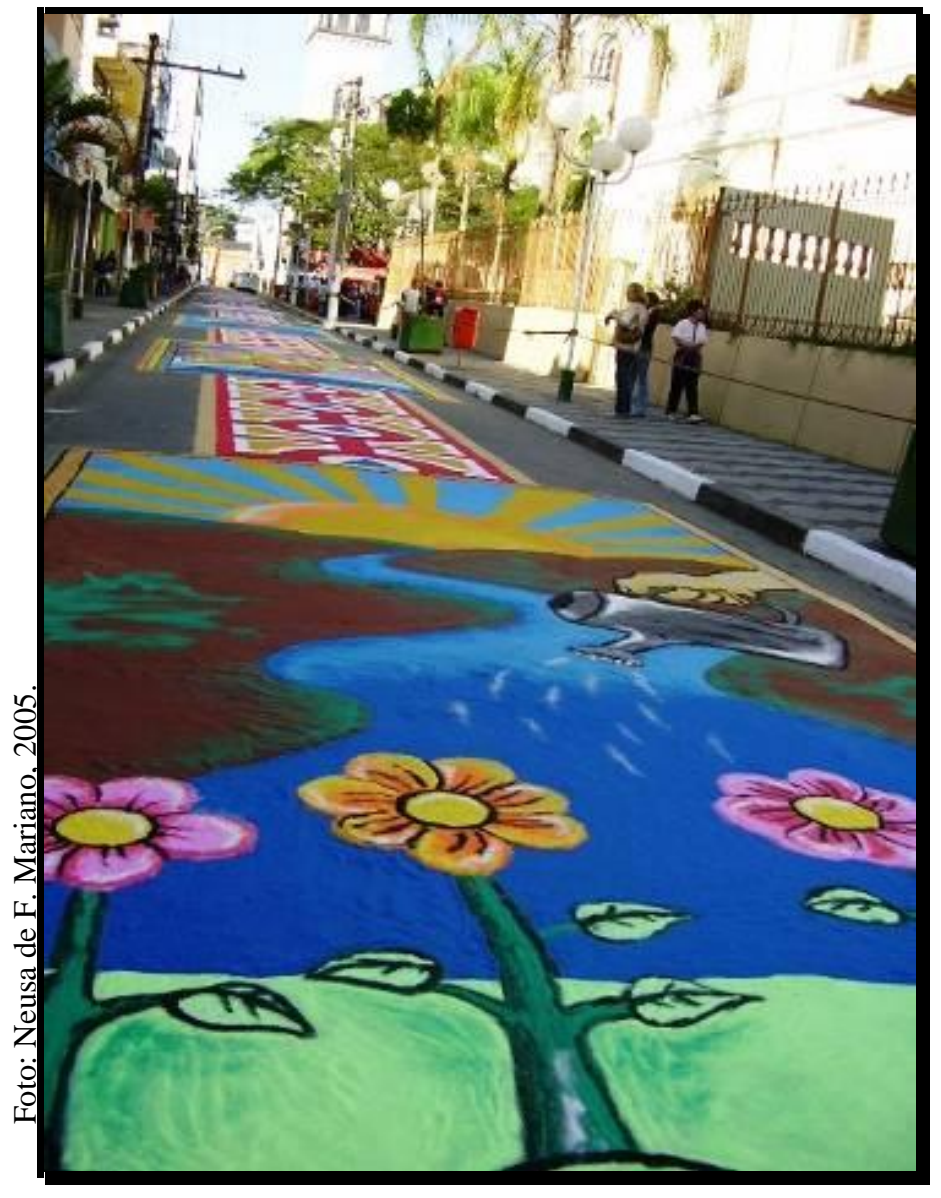

Porque em Mogi não tem esse tapete do Corpus Christi. Ele [o Festeiro] me pediu, nós arregimentamos algumas escolas e confeccionamos $o$ primeiro tapete em 1994. De lá para cá, começou a se transformar numa tradição da Festa do Divino de Mogi das Cruzes.

Mathias

\section{pdfMachine}

A pdf writer that produces quality PDF files with ease!

Produce quality PDF files in seconds and preserve the integrity of your original documents. Compatible across nearly all Windows platforms, simply open the document you want to convert, click "print", select the "Broadgun pdfMachine printer" and that's it! Get yours now! 
Ainda segundo o Sr. Mathias, a Associação Pró-Festa do Divino, através da coordenação do tapete, fornece às escolas e demais instituições a temática da Festa, que faz parte do logotipo"146; em 2003 era "Fé, Família e Cultura", em 2004 "Família, Amor e Esperança", em 2005, "Fé, Família e Caridade", em 2006 "Família, Construtora de Fraternidade e Paz", e em 2007 "Família e Missão, o Caminho para Cristo", temas estes escolhidos pelos Festeiros e Capitães de Mastro de cada ano.

O Bispo é o primeiro a pisar no Tapete, durante a Procissão de Pentecostes, porque ele é a autoridade máxima da Igreja presente no evento. Nas margens das vias há duas faixas livres, sem tapete, para que todos os que estão antes do Bispo possam passar em fila, uma de cada lado. Após a passagem do Bispo, todos podem caminhar sobre o Tapete, desfigurandoo, conseqüentemente. Alguns fiéis recolhem um pouco do material do tapete que sobrou, acreditando ser sagrado e estar bento, afinal é o Tapete do Divino.

A imagem do Divino é levada para dentro da Catedral de Santana, onde é celebrada missa solene, em homenagem ao Espírito Santo, pelo Bispo Diocesano de Mogi das Cruzes. Cabe mencionar que é necessário telão do lado de fora da Catedral, uma vez que não cabem todos os fiéis na igreja para assistir à celebração.

Mais uma vez, para mostrar a eficiência na limpeza das vias públicas, nos anos de 2005 e 2006, assim que a procissão passou e se distanciou, os garis foram atrás, recolhendo o material do tapete já desfigurado e jogando seus restos no caminhão de limpeza (Foto 58). Em poucos minutos as ruas, antes cobertas pelo tapete, estavam completamente lavadas e sem vestígios da Procissão.

Logo após a missa ocorre a queima dos pedidos ao Espírito Santo: os que foram depositados em uma urna, dentro do Império do Divino; os que estavam nas caixinhas das Rezadeiras; e as fitas de bandeiras do Divino, cujos nós feitos pelos devotos representam pedidos e agradecimentos ao Espírito Santo. Este ritual, que simboliza a ascensão dos pedidos dos fiéis ao Espírito Santo, conta com a presença do Bispo, dos Festeiros, dos Capitães de Mastro e de devotos em geral. Os Festeiros, após uma prece, fecham as portas do Império do Divino que serão reabertas somente um ano depois, na próxima Festa.

Geralmente durante as celebrações de Corpus Christi é anunciado o nome dos novos Festeiros pelo Bispo Diocesano. E tudo começa outra vez.

${ }^{146}$ A temática da Festa parece ser coisa recente, pois não foram encontrados registros sobre os temas em Festas do Divino mais antioas de Mooi das Cruzes 
Foto 57.

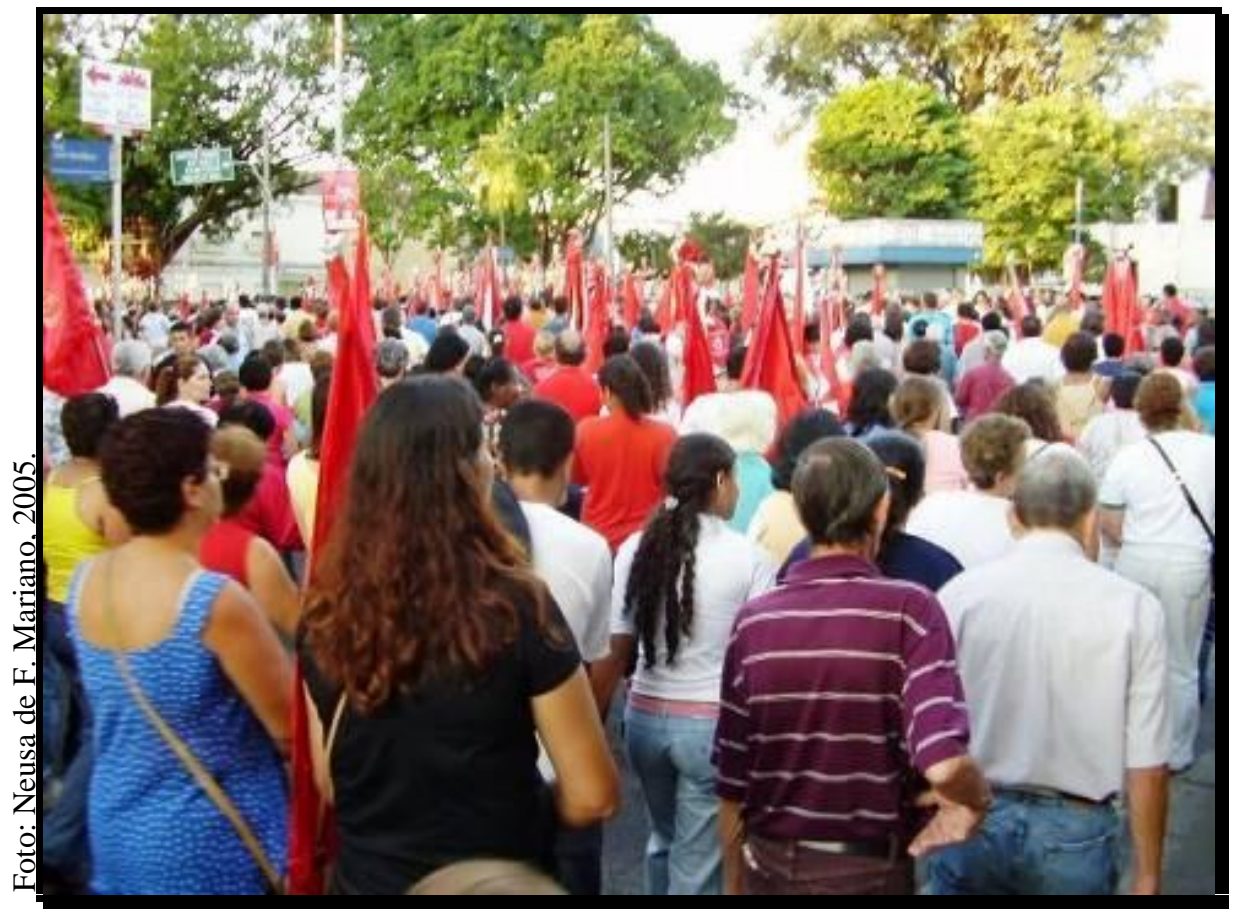

A multidão participa da Procissão de Pentecostes, que termina na Catedral de Santana, onde é celebrada a Missa de Pentecostes.

Foto 58.

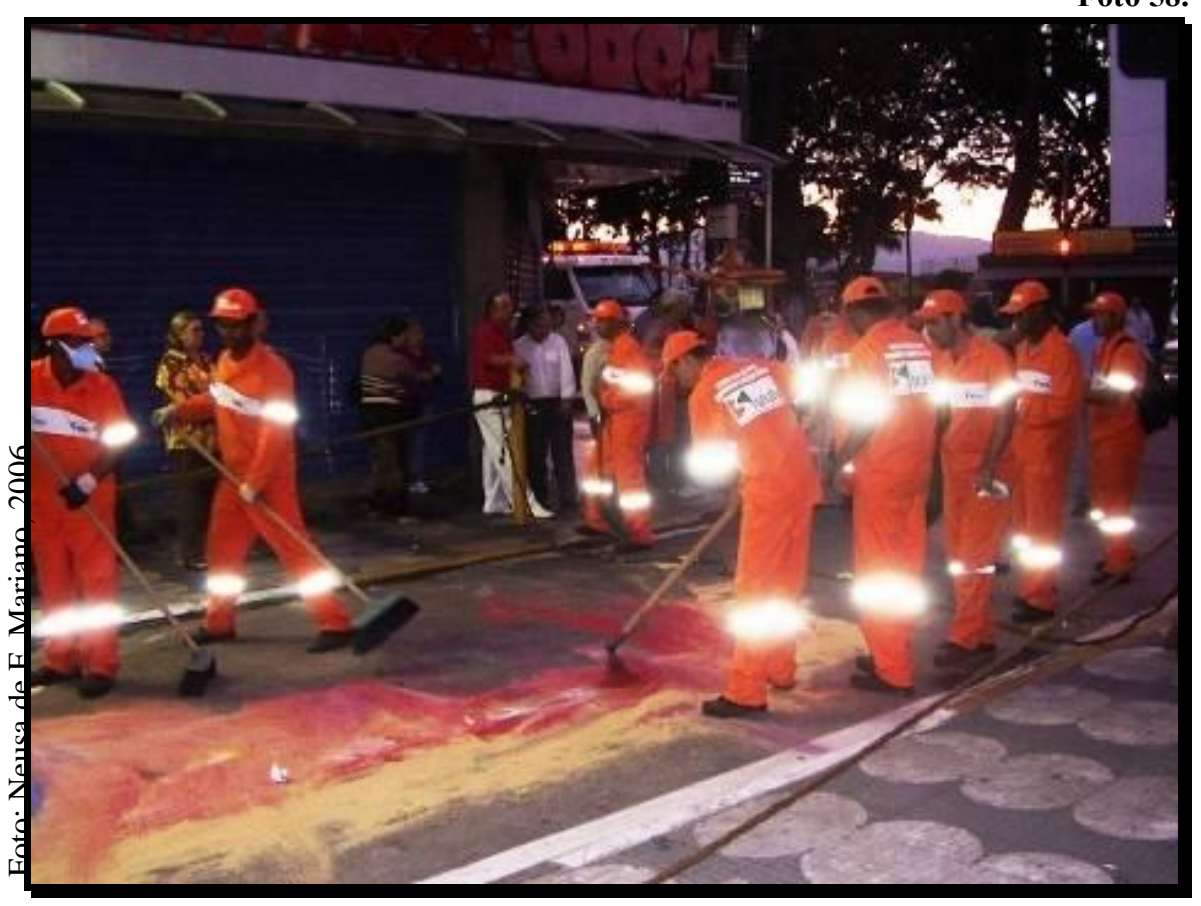

Os garis já estão prontos para começar a trabalhar assim que a Procissão termina de passar sobre o Tapete Ornamental.

\section{pdfMachine}

\section{A pdf writer that produces quality PDF files with ease!}

Produce quality PDF files in seconds and preserve the integrity of your original documents. Compatible across nearly all Windows platforms, simply open the document you want to convert, click "print", select the 
Para que a Festa se realize conforme apresentamos, faz-se necessário arrecadação de grande quantia em dinheiro, pois há muitos gastos que não seriam cobertos, valendo-se apenas dos donativos e recursos resultantes dos bingos e da Quermesse. Por isso, do Livro de Ouro de antigamente, passou-se aos patrocinadores/parceiros/apoiadores da Festa, numa relação de mercado, bem mais complexa.

Para Reginaldo (ex-Festeiro), gasta-se muito com a parte chamada folclórica da Festa, que demanda, também, trabalho de voluntários. Algumas despesas estão relacionadas aos alojamentos para os carros de bois, charretes e cavaleiros que participam da Entrada dos Palmitos; à confecção de panfletos, bandeirinhas, livrinhos de orações e cânticos, programação, etc.; ao deslocamento dos grupos de Congada e Moçambique ${ }^{147}$; à construção e decoração do Império do Divino, da Catedral de Santana e do tapete ornamental. Ainda há gastos com ajuda de custo de cerca de $\mathrm{R} \$ 500,00$ (quinhentos reais) oferecida a cada "grupo folclórico”, além do uniforme e alimentação da Folia do Divino durante o período da Festa.

Mesmo com as muitas doações que recebem dos devotos através das escolas, das Rezadeiras, dos chás-bingo e Quermesse, segundo Caíque, a Festa, cujo custo chega a R\$ 400.000,00 (quatrocentos mil reais), não se paga, sendo necessário o patrocínio de empresas. Estas, recebem em troca, o seu logotipo no material de divulgação da Festa, nos aventais, bonés e lenços dos voluntários da Quermesse.

A coordenação de maketing da Pró-Divino, neste sentido, é primordial para a Festa, pois é ela quem atua junto às empresas, na captação de recursos, desde o ano de 2000 de forma mais sistematizada (O DIÁRIO DE MOGI, 20/05/2000). Desta forma, são vendidas quotas de valores diferentes conforme o destaque para o logotipo da empresa: banners, camisetas, bonés, aventais, lenços. Ao mesmo tempo em que surgia esta nova forma de negociação de recursos para a Festa, a Associação Pró-Divino produzia um Manual Operacional, que registrava:

Se é importante manter a Festa, muito mais importante é manter os detalhes de sua tradição [...].

Não podemos deixar que a Festa se transforme num movimento puramente econômico/financeiro, esquecendo-nos da extrema importância de seus

${ }^{147}$ Esses grupos são oriundos de locais um pouco distantes do centro de Mogi das Cruzes, como Braz Cubas Cezar de Sowza 
aspectos social e religioso. (Manual Operacional da Festa do Divino, 2000: 19).

Essa preocupação sempre presente no discurso dos membros da Associação PróDivino não "freou" o crescimento da Festa, que se deu também através da divulgação feita pela TV Diário e pelos jornais locais, que se tornaram parceiros do evento. Com a Festa bem divulgada, ela se torna um investimento, sendo utilizada para fazer propaganda das empresas.

Sem comprar quotas, as Universidades de Mogi das Cruzes e Braz Cubas apóiam a Festa através da impressão de folhetos com os cânticos das missas e Alvoradas e cartazes de divulgação, como afirmou o Sr. Saul Grinberg, além de serem estabelecimentos com atividades voltadas para a divulgação (palestras, debates, campanhas para voluntários, etc.).

As escolas também se tornaram vias de divulgação da Festa do Divino, a partir da montagem e inauguração de Subimpérios ${ }^{148}$, momento em que são visitadas por representantes da Associação Pró-Festa, algumas delas, pelos próprios Festeiros. Nas escolas são solicitados aos estudantes, produtos comestíveis como prendas, para a confecção dos doces da Festa.

Poderia citar vários exemplos, mas a intenção é apenas mostrar que os auxílios abrangem desde a pequena contribuição do devoto, aquele que doa uma pasta de dente, até grandes somas vindas de empresas do porte da General Motors ${ }^{149}$. No Relatório Final da Festa do Divino de 2002, organizado pela Associação, constam trinta e um patrocinadores, variando de grandes (Divena, Pão de Açúcar, Bradesco) a pequenas empresas (Guarudonto, Escritório Hélio). Ao pé dos cartazes das Festas de 2003 a 2006 temos os logotipos das seguintes empresas: Banespa, Banco do Brasil, Barateiro, Hipermercado D’Avó, Habib's, PETROM, LOCAR - Transportes Técnicos e Guindastes, Chevrolet, INAL - Empresa CSN, Instituto General Motors, Cia. Suzano de Papel e Celulose, Oscar Calçados, Itaipu Shopping Construção, Nancy (moda), Universidade de Mogi das Cruzes, Universidade Braz Cubas e Prefeitura Municipal de Mogi das Cruzes.

O marketing da Associação para a Festa torna-se também marketing das empresas, a partir e em nome de uma tradição religiosa popular, embora a Associação Pró-Divino

${ }^{148}$ Segundo Márcia, coordenadora da Pró-Divino, no início dos anos 1990, apenas três escolas montavam Subimpério, e hoje, somam cerca de cem. Tanto a Prefeitura como estabelecimentos comerciais (principalmente parceiros da Festa), também têm montado Subimpérios.

149 Instalada em Movi das Cruzes desde 1990 na Zona Industrial do Tahoa 
entenda que a empresa é que deve divulgar a Festa e não o contrário. Ao questionar algumas pessoas envolvidas com a Associação Pró-Divino sobre o crescimento da Festa e o risco da perda de tradições em favor das empresas, a resposta vem em uníssono: "A Associação não deixa!"

Alguns defendem a necessidade de se trazer novidades para a Festa, porém desde que não a descaracterizem. Pensando assim, Caíque acredita que há espaço para os empresários mostrarem o seu logotipo na Festa, mas jamais seriam os mesmos espaços do Espírito Santo: “É preciso ter a sensibilidade e saber onde e como colocar o logotipo das empresas".

Em 2004, ocorreu um episódio que, segundo Márcia, uma das coordenadoras da Pró-Divino, mostra que a propaganda fugiu ao controle da Associação:

Há dois anos atrás o pessoal do supermercado, um grupo que fazia ginástica, com camiseta do supermercado D'Avó, na Entrada dos Palmitos. Eu só fiquei sabendo na hora. Mas tinha anuência dos Festeiros. Eu fiquei louca com os organizadores da Entrada dos Palmitos. Porque, lógico que tudo o que é patrocinador quer a vitrine... A maior vitrine da festa é a Entrada dos Palmitos, e a gente segura para não colocar nada que seja patrocínio para não perder, para perder o mínimo possivel da tradição, da seriedade da Entrada dos Palmitos. [...] Não é nem por maldade... porque [o Festeiro] quer agradar quem deu o dinheiro para ele, lógico.

A Entrada dos Palmitos, como momento mais atrativo da considerada parte folclórica da Festa do Divino, reúne cerca de quarenta a cinqüenta mil pessoas que a assistem. Ao atingir bastante gente, o cortejo estrategicamente pode tornar-se vitrine dos patrocinadores da Festa.

Mônica (Capitã de Mastro de 2006) cita um exemplo no qual a Associação e os Festeiros não se curvaram aos interesses empresariais:

Eu falo de uma empresa que queria patrocinar, mas estava com problemas com a cidade, com a prefeitura, com os moradores. [...]. Ela disse que nos ajudaria, mas nós achamos por bem que não deveria aceitar esse patrocínio porque iria entrar em conflito, praticamente com a cidade. A gente não estava vendo só essa parte financeira. Se fôssemos olhar a parte financeira estaríamos tranqüilos, mas nós vemos a outra parte e decidimos por isso. ${ }^{150}$

${ }^{150}$ A partir de outras entrevistas, e de artigo do jornal Mogi News (05/05/2005), há a suspeita de que a emnresa é a Oweiroz Galvão aw eweria instalar um aterro sanitário na cidade de Maoi das Cruzes pdfMachine

A pdf writer that produces quality PDF files with ease!

Produce quality PDF files in seconds and preserve the integrity of your original documents. Compatible across nearly all Windows platforms, simply open the document you want to convert, click "print", select the

"Broadgun pdfMachine printer" and that's it! Get yours now! 
Para Mário Sérgio ${ }^{151}$, o patrocínio é primordial para a Festa, no entanto é sempre um risco para a manutenção das tradições:

Eu vejo mais como um diálogo natural e perigoso. Natural porque a gente não pode estancar a festa como se fosse uma espécie de uma redoma, impossivel! Então, natural neste sentido. É preciso que a sociedade desperte para um diálogo entre o novo e a tradição. [...] Então não é porque a Rede Globo está lá e ela vem com o karaokê, e ela vem lá com a sua imagem plastificada, ela vem com um sentido muito aguçado de produto cultural, que eu vá simplesmente aceitá-la. [...] Mas eu tenho a impressão que tem coisas que passam na festa do Divino que ainda isso aí está sendo detido, por exemplo, da publicidade comercial que se faz, vindo principalmente de grandes mercados, você percebe que a publicidade está contida ainda. Ou seja, a imagem da pomba, da inspiração, ela é ainda mais forte que as marcas.

O risco do desvirtuamento existe, mas a Festa como mercadoria parece não fazer parte dos discursos da Associação, cujos membros defendem a preservação da tradição (e quanto mais antiga melhor). Observemos, no entanto, que a Festa é negociada a todo o momento com empresas, numa relação sem a qual ela não se realiza. Utilizo poucas palavras apenas no sentido de chamar a atenção, ou provocar uma discussão que retomarei mais adiante: a tradição e a religiosidade não deixam de ser mantidas, mas a Festa do Divino também não deixa de ser produto e espetáculo.

Cabe mencionar ainda os órgãos públicos contatados pela Associação, que vêm auxiliar na logística da Festa do Divino. Há diálogo constante com a Prefeitura, seja na Coordenação de Cultura, seja na limpeza das ruas, bem como há preocupação com a segurança, contando com o trabalho das Polícias Militar e Civil, e do Exército. Explica o Sr. Mathias, que todos os serviços necessários são solicitados formalmente aos órgãos públicos. Desta forma, a Associação pretende que a Prefeitura

[...] arque com a montagem de palco, com parte da Quermesse, da água, da luz, essas coisas, eles arquem com tudo - dêem o pessoal, o material, e dêem todo esse apoio. Na parte de tapete, por exemplo, limpeza de rua, cercar com corda... A gente já antecipadamente estuda, passa para cada coordenador, para ver a necessidade que ele tem - dentro do quê a gente já colocou - ver se ele precisa de mais alguma coisa, e manda para a Prefeitura. A Prefeitura marca um dia, uma reunião, que é para a gente se reunir com todos os responsáveis pelos setores da Prefeitura. [...]. A gente precisa pôr ambulância, segurança, enfim, uma série de coisas, limpeza da estrada. [...] Então, nós pedimos médico, ambulância, bombeiro. [...] Por exemplo, a Entrada dos Palmitos: precisa vir na frente o pessoal do

151 Presidente da Cáritas Diocesana 
trânsito fechando as ruas, que é para o cortejo poder passar. Nós temos a Alvorada, que também precisa parar o trânsito. [...] E tudo isso está incluído no ofício. O prefeito é que vai ver quem é que vai cuidar de cada parte.

Assim, entendemos que a Associação Pró-Divino funciona segundo a racionalidade empresarial, embora não tenha fins lucrativos. Organizada a partir de coordenadorias, é a Associação que mantém o diálogo com os patrocinadores, com os órgãos públicos municipais e estaduais, auxilia os Festeiros e Capitães de Mastro em suas funções. Busca, nas pesquisas históricas, elementos que estavam presentes na Festa do passado, com o objetivo de resgatá-los. Agrega Rezadeiras, voluntários, comunidades, artistas plásticos (pintores, escultores, fazedores de bandeiras) e devotos. E por fim, presta contas à Mitra Diocesana, depois de pagas todas as despesas da Festa, pronta para começar tudo de novo e perpetuar a tradição.

Parece inegável que a própria existência da Associação Pró-Divino, assim como o modo de sua atuação, são indicativos da transformação da Festa em mercadoria, em produto de consumo da chamada indústria cultural.

\subsection{A terceira parte da Festa: a Quermesse}

A gente fazia questão de ir à quermesse, nem que fosse para dar uma passadinha no finalzinho, porque é uma coisa que os voluntários gostam.

Reginaldo, Festeiro do Divino de 2005

Depois de várias mudanças de local de realização (Mapa 4), a partir de 2003 a Quermesse começou a ser realizada no Centro de Iniciação Profissional, distante do Império do Divino, a centralidade da Festa. O CIP é um local grande o suficiente para abrigar as cerca de quarenta barracas de comidas, bebidas, doces, além de um conjunto de diversões como o bingo, o karaokê, shows, etc. (Croqui 1). 


\section{Croqui 1 - Quermesse da Festa do Divino de Mogi das Cruzes - CIP (2005)}

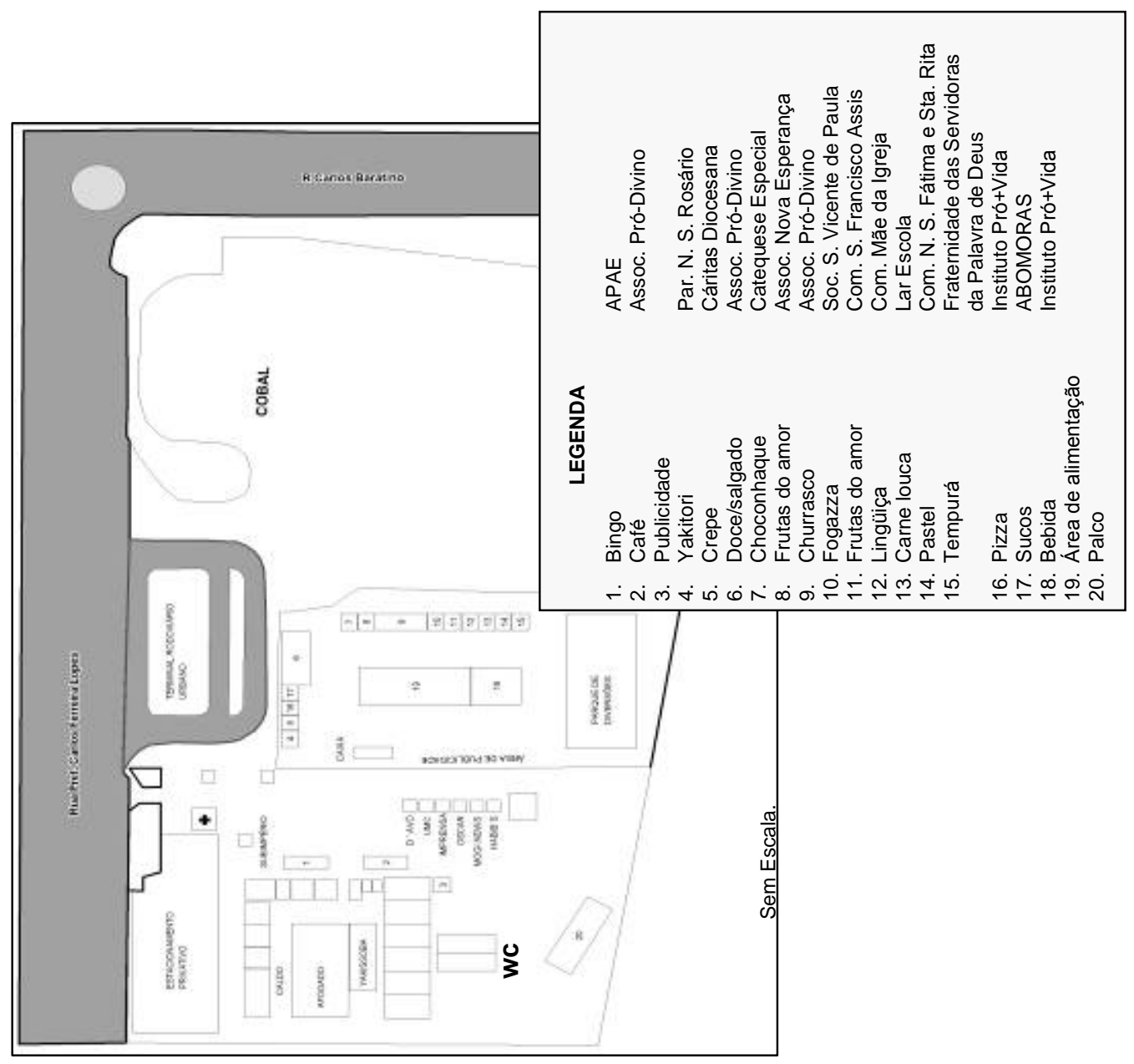

Fonte: Festa do Divino 2005. (Sem Escala). In: Mogi News. Cidades. Quinta-Feira, 05 de maio de 2005, p. 3.

Elaboração: Rinaldo Gomes Pinho e Neusa de Fátima Mariano.

\section{pdfMachine}

A pdf writer that produces quality PDF files with ease!

Produce quality PDF files in seconds and preserve the integrity of your original documents. Compatible across nearly all Windows platforms, simply open the document you want to convert, click "print", select the 
Atividade de todas as noites, a Quermesse conta com o trabalho voluntário dos devotos nas barracas oficiais, organizadas pela Associação Pró-Festa do Divino Espírito Santo (Fotos 59 e 60). Aliás, o voluntariado está presente em todos os momentos da Festa do Divino, muitas vezes como uma maneira de pagar promessa feita ao Espírito Santo.

Voluntárias carinhosamente conhecidas como "Abelhinhas do Divino", se dedicam à confecção de doces e salgados para a Quermesse. Considerado, pelos participantes, comida caipira da Festa, o tortinho faz sucesso, sendo produzidas, de setecentas a novecentas e cinqüenta unidades por dia. $\mathrm{O}$ salgado frito que tem formato de meia lua, é feito com farinha de milho e recheado com carne moída ${ }^{152}$.

O Afogado ${ }^{153}$ também pode ser saboreado, bem como o vinho quente e o quentão, café feito no fogão à lenha, além da pipoca e do pão de queijo. E não poderia faltar o churrasco do Divino: pão com a "carne temperada com os sete dons do Divino", como dizem os devotos. São incorporados a esse conjunto de comes e bebes típicos de quermesse, comidas italianas (pizza, panqueca e afins), comida oriental (yakissoba e tempurá), comida portuguesa (bolinhos de bacalhau), e caldos (de feijão, caldo verde...), e ainda o "choconhaque" (mistura de chocolate com leite quente e uma dose de conhaque, temperado com cravo e canela), refrigerantes e cervejas. No ramo dos doces, chamam a atenção os morangos e uvas cobertos com chocolate ${ }^{154}$. Não se pode esquecer do espaço de exposição de artes, onde quadros, fotos e esculturas representam temas sobre o Divino Espírito Santo e a Festa. "Lembrancinhas" da Festa podem ser adquiridas na Quermesse: são pombinhas representando o Divino, dentro de cestas de gesso, ou em formato de medalhinhas, lenços com o logotipo da Festa do ano corrente, orações, pulseiras, terços, bandeirinhas, etc.

A Quermesse aglutina entidades assistenciais que montam suas barracas de comes e bebes ficando com 75\% do que arrecadam. Em 2006 eram as seguintes entidades: Instituto Pró Mais Vida; Catequese Especial; DOM - Dislexia Organização Mogiana; Cáritas Diocesana; Sociedade São Vicente de Paula; Comunidade São Francisco de Assis;

${ }^{152} \mathrm{O}$ movimento na cozinha da Casa da Festa começa às 9:00h da manhã e termina por volta de 18:00h, mas nem todos os voluntários, que chegam ao número de setenta, ficam o dia todo. À tarde, tomam um café com leite, bolo, torta, mas só depois de rezar e agradecer ao Espírito Santo por mais um dia, conforme Dona Maria José, coordenadora da Casa da Festa.

${ }^{153} \mathrm{O}$ Afogado da Quermesse é vendido à população, e não distribuído como acontece depois da Entrada dos Palmitos.

154 A venda das guloseimas se faz mediante entrega de fichas adquiridas previamente, seu preço

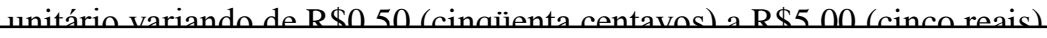


Comunidade Mãe da Igreja; Lar Escola; Casa Irmã Salvadora; Associação Beneficente Onde Moras? (ABOMORAS); Comunidades Nossa Senhora de Fátima e Santa Rita; e finalmente, Paróquia Nossa Senhora do Rosário (O DIÁRIO DE MOGI, 07/06/2006).

Desde 2005, uma reorganização das barracas da Quermesse facilitou a circulação entre elas. Um Parque de Diversões divide o espaço mais ao fundo, próximo do palco onde são realizados shows de violeiros (alguns já consagrados) e o Festival de Viola, sob os cuidados do Sr. Jorge Correia, coordenador de eventos da Associação Pró-Festa do Divino.

Mais para o meio do espaço da Quermesse, em direção ao portão principal está o estande da TV Diário, afiliada à Rede Globo. Lá, um rapaz bastante conhecido principalmente pelos adolescentes da região, apresenta um programa que promove namoros e um programa de $\operatorname{karaok}^{155}$. O estande funciona como um divisor de ambientes e de público: ao fundo o pessoal mais velho apaixonado pela música caipira e, mais à frente, o grupo dos adolescentes. Em paralelo a este estande, as barracas de comes e bebes, posto de venda de fichas ao centro, e a praça de alimentação (a novidade de 2005 que se manteve em 2006) montada sob uma grande tenda, junto à barraca de cerveja e refrigerante, com mesas e cadeiras à disposição. Nessa tenda da alimentação foram colocadas caixas de som que transmitem uma programação especial para a Festa, a da Divina Rádio, com seu repertório eclético. A Rádio é um meio de divulgação dos patrocinadores/parceiros/apoiadores da Festa, anunciados com freqüência entre uma seqüência de música e outra.

Do lado de fora, na entrada do CIP, adolescentes se aglomeram com bebidas alcoólicas em recipientes PETs e obstruem a passagem pelo grande número em que se encontram, mas dificilmente entram na Quermesse. A Associação Pró-Divino vê nisso um problema porque quando resolvem entrar, os adolescentes já estão alcoolizados e, embora haja segurança pública e privada, sempre se corre o risco de conflitos no espaço da Quermesse. Geralmente os conflitos não chegam ao conhecimento da população, por serem “abafados" pela Associação ${ }^{156}$ junto à imprensa. No intuito de solucionar o problema, em

${ }^{155}$ Em 2006 já não havia mais esta atividade na Quermesse. Explicou Caíque, um dos coordenadores da Associação Pró-Divino, que o convite à TV Diário não foi feito, entre tantos contratempos, devido ao falecimento de sua mãe, que muito se dedicava à Festa do Divino, abalando assim, os trabalhos da Associação. O Sr. Josemir, também da Pró-Divino, deu a entender que, na verdade, a ausência do karaokê tinha sido uma conquista da Associação já que a sua presença não agradava a muitos.

${ }^{156}$ A maioria das pessoas entrevistadas ressalta que apesar da Festa do Divino ter crescido muito nos últimos tempos, não tem tido brigas em seu histórico, abençoada que é pelo Espírito Santo. Na

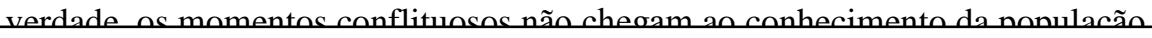


2005 a Associação Pró-Festa do Divino propôs a cobrança de ingresso para a Quermesse. O tíquete no valor de $\mathrm{R} \$ 1,00$ (um real) poderia ser trocado em qualquer barraca da Quermesse, quando efetuada a compra de algum produto.

Diante da polêmica que a proposta gerou, mesmo no interior da própria Associação, a idéia de cobrança de ingressos não foi concretizada. O problema continua.

Cabe aqui um parêntese para falar sobre a Tarde de Folguedos Infantis, atividade realizada no primeiro domingo da Festa, no CIP. A intenção é resgatar brincadeiras antigas ${ }^{157}$ como cabra-cega, lencinho-na-mão, roda, corrida do saco e a corrida de equilíbrio do ovo na colher... Mas o objetivo maior é incluir os jovens no espírito da Festa, envolvendo estudantes das Universidades Braz Cubas e de Mogi das Cruzes, que monitoram, voluntariamente, as crianças na gincana. Esta seria uma das formas de se trabalhar as causas do problema logo acima citado, mas diretores da Associação Pró-Divino reconhecem que algo mais eficaz, no sentido de atrair os jovens para a Festa, precisa ser feito.

Assim como a Entrada dos Palmitos, a Quermesse parece ser um espaço em que "tudo" é permitido. Os "grupos folclóricos", por exemplo, que ali se apresentavam, ganharam o espaço do palco para a dança em 2006, o que não agradou a todos os dançadores $^{158}$. Neste mesmo palco acontece o Festival de Música Sertaneja, além de apresentações de artistas renomados.

Mas, o que chama bastante atenção são os voluntários da elite da cidade, que trabalham na barraca do "Afogado", na Quermesse. No jornal O Diário de Mogi (28/05/2004), o Sr. Airton Nogueira conta como começou o voluntariado com a participação de empresas:

[...] a demanda era tão grande que o número de voluntários não dava conta do serviço, que é muito pesado. Então, Nogueira, ao lado de seus ajudantes, teve a idéia de convidar segmentos da sociedade para participarem da Festa. Assim, funcionários de bancos, empresas, prefeitura, escolas e universidades começaram a dar reforço ao trabalho nas barracas. "O interessante da nova medida, que conquistou apoio de mais pessoas, foi que autoridades como o prefeito e secretários passaram a servir o povo", comenta Nogueira.

Assim, funcionários do jornal O Diário de Mogi e da Prefeitura são convocados a

${ }^{157}$ Algumas das brincadeiras mais antigas como o pau-de-sebo e a do porco ensebado não são mais realizadas devido às leis de proteção aos animais e segurança das crianças, já que podem causar algum acidente grave. 
trabalhar na Quermesse, na qualidade de voluntários, durante uma noite ${ }^{159}$. Não só os empresários e a autoridade municipal ganham notoriedade, por mais anônimos que estejam, trajados com aventais e lenços da Festa, mas as empresas, através de seus funcionários, realizam o marketing, quando são notícia nos jornais. Com isso, a afirmação ouvida em entrevista de que a Festa do Divino é um momento em que as diferenças sociais não existem, é negada. As diferenças já aparecem nos casais de Festeiros e Capitães de Mastro, que precisam ter certo conhecimento administrativo e financeiro, além de contatos empresariais para conseguir patrocínios para a Festa. Em outro ponto, encontramos voluntários da Quermesse, pertencente a uma elite da cidade, como descrito logo acima. Apesar de trabalharem ao lado do povo em posição de igualdade, a imprensa não deixa de lhes dar destaque, tirando-os do anonimato aparente.

${ }^{158}$ Conforme entrevistas.

159 Conforme Reoina funcionária do Diário de Mooi 
Foto 59.

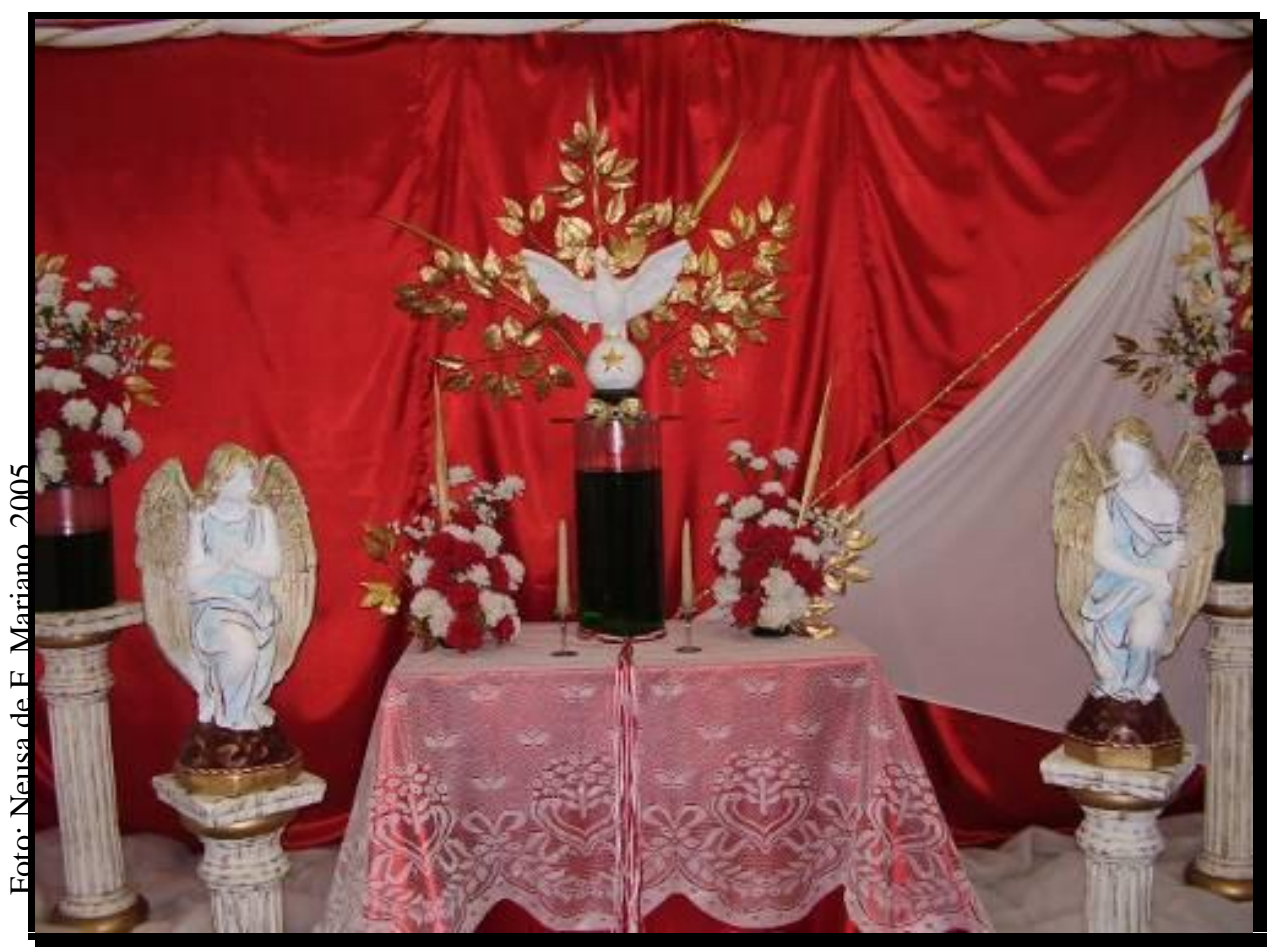

Subimpério do Divino Espírito Santo da Quermesse, inaugurado no mesmo dia do Império do Divino.

Foto 60.

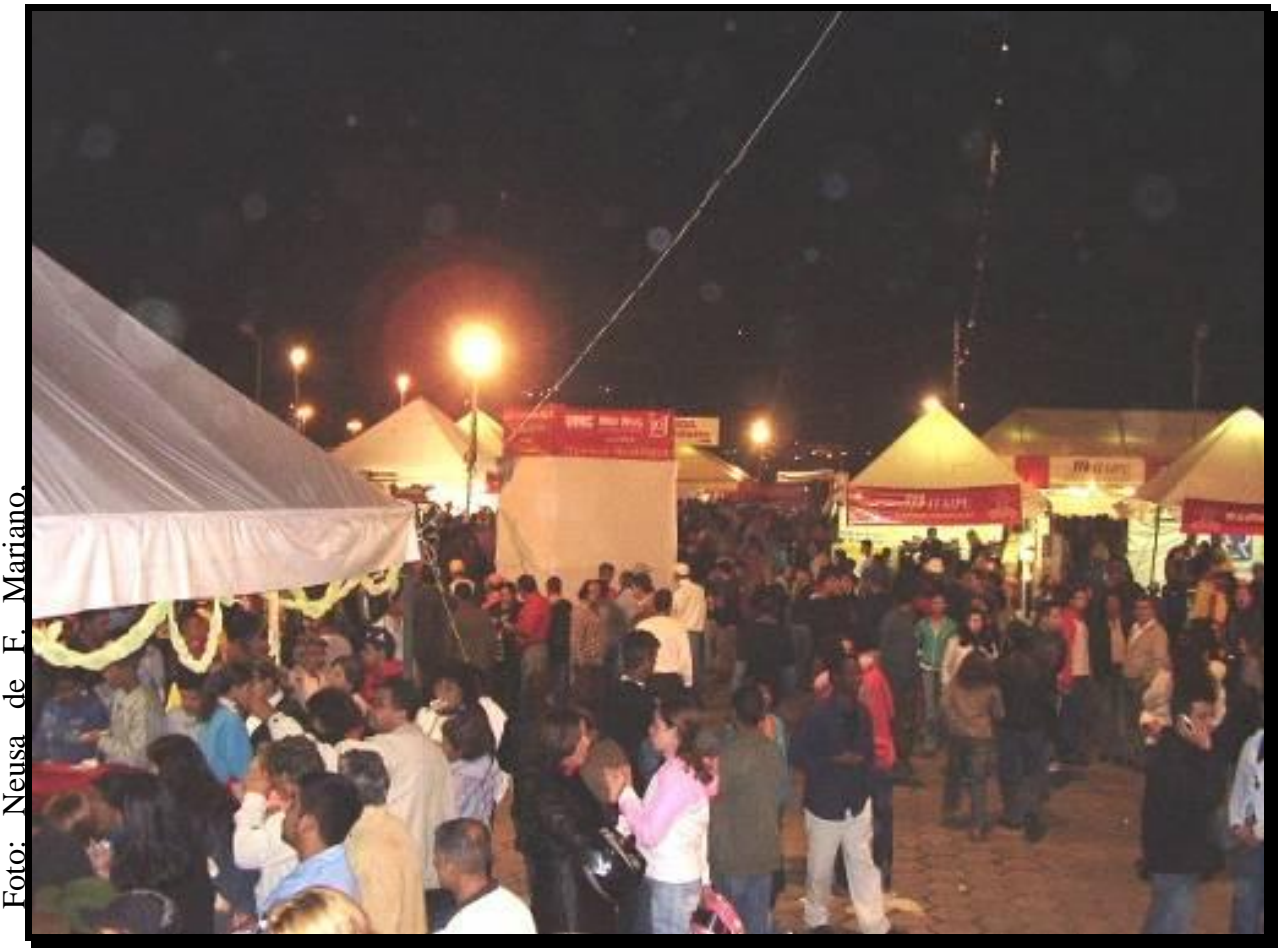

A quermesse é muito longe [...], então esse ano eu não fui uma vez.

Elisete

\section{pdfMachine}

A pdf writer that produces quality PDF files with ease!

Produce quality PDF files in seconds and preserve the integrity of your original documents. Compatible across

nearly all Windows platforms, simply open the document you want to convert, click "print", select the

"Broadgun pdfMachine printer" and that's it! Get yours now! 


\subsection{Festas do Divino em todos os cantos de Mogi das Cruzes}

Eu só não sei dizer como que eles calculam data, ou se eles simplesmente se reúnem. Não pode atropelar a daqui.

Sr. Mathias

A Festa do Divino Espírito Santo de Mogi das Cruzes parece ter influenciado a realização ou o fortalecimento de outras menores, hoje, nos distritos ou bairros mais distantes do centro da cidade. Apresentamos brevemente ${ }^{160}$ algumas destas Festas do Divino menores, que se realizam em datas ${ }^{161}$ e de maneiras diferentes entre si.

Já nos referimos à Festa do Divino do distrito de Biritiba Ussu quando apresentamos a Folia do Divino. A Festa tem sido realizada, há cerca de cem anos, na então capela de Santa Cruz, erguida em $1867^{162}$.

A programação da Festa do Divino, realizada de 22 a 29 de maio de 2005, teve início com a missa de abertura da Festa e a inauguração do Império do Divino, erguido em um salão nos fundos da igreja de Santa Cruz (Foto 61). No decorrer da semana, foram feitas orações em homenagem ao Espírito Santo, seguidas pela Quermesse, instalada em volta da igreja.

No sábado, aconteceu a Entrada dos Palmitos, um dos momentos de maior destaque, da festividade. Aqui, diferente de Mogi das Cruzes, carros de bois não participam do cortejo há cerca de trinta anos ${ }^{163}$. Tratores agrícolas os substituíram e agora são eles que chamam atenção no desfile, enfeitados com palmeiras e flores (Foto 62). A presença de

${ }^{160}$ Uma análise mais detida destas festas menores implicaria uma ampliação da pesquisa que poderia até inviabilizá-la.

${ }^{161}$ Geralmente as datas destas Festas não coincidem com a data da Festa do Divino de Mogi das Cruzes. Assim, organizadores das Festas dos distritos podem atuar como voluntários na Festa de Mogi, e os grupos de Congada e Moçambique podem dançar também nas Festas menores.

${ }^{162}$ Uma nova igreja de Santa Cruz foi inaugurada em 1991 ou 1992, já que a antiga estava ruindo, segundo afirmou o Sr. Moacyr, administrador do Distrito de Biritiba Ussu, em conversa rápida durante a Festa do Divino em 2005.

163 Conforme Sr Hlisses 
tratores na Entrada dos Palmitos na Festa do Divino Espírito Santo, neste caso, pode ser entendida como um ajustamento da tradição ao processo de modernização. Os carros de bois não são mais usados no campo, e a colheita está agora dependente do trabalho mecanizado: o trator é o instrumento de trabalho e, por isso, deve ser abençoado pelo Espírito Santo.

Festeiros, Capitães de Mastro e devotos foram à frente (Foto 63), no desfile, carregando as bandeiras do Divino, seguidos de crianças vestidas com túnicas brancas; depois seguiam os cerca de cinqüenta tratores, os carros e as camionetes (que juntos somavam vinte e cinco) ${ }^{164}$ e, por último, a Congada de São Benedito, oriunda do distrito de Cezar de Souza (Foto 64). O cortejo com aproximadamente trezentas pessoas, seguiu pela Estrada Dom Paulo Rolim Loureiro, a conhecida Mogi-Bertioga, percorrendo 1,3 Km da Estrada $^{165}$, em direção à igreja de Santa Cruz.

Postes, no interior do núcleo urbano, foram enfeitados com palmeiras e "banners" com os dons do Espírito Santo ou, simplesmente, com uma pomba branca desenhada. A concentração dos devotos e demais participantes na Praça da igreja foi animada pelos cantos católicos de um grupo de jovens que se apresentou no palco, montado no local. Os agricultores e seus tratores foram aspergidos com água benta, pelo Padre. Cabe observar que na Festa de Biritiba Ussu, o Afogado, em nenhum momento é distribuído, mas vendido aos interessados ${ }^{166}$.

À noite, a Folia do Divino participou da Passeata das Bandeiras, e, no último dia da Festa (domingo) houve uma missa pela manhã, Procissão de Pentecostes à tarde, e fogos de artifício à noite, momento em que o Império do Divino foi fechado.

${ }^{164}$ Conforme informações obtidas, durante a Festa do Divino de Biritiba Ussu, em maio de 2005, da Polícia Rodoviária.

${ }^{165}$ A Estrada é interditada em uma via e liberada logo após a passagem da Congada (último grupo da procissão).

${ }^{166}$ Segundo Sueli, uma das organizadoras da Festa do Divino de Biritiba Ussu, há cerca de trinta anos, os fazendeiros da região chegavam a doar oito bois para o Afogado, que era distribuído entre odfMachine A pdf writer that produces quality PDF files with ease!

Produce quality PDF files in seconds and preserve the integrity of your original documents. Compatible across nearly all Windows platforms, simply open the document you want to convert, click "print", select the "Broadgun pdfMachine printer" and that's it! Get yours now! 
Foto 61.

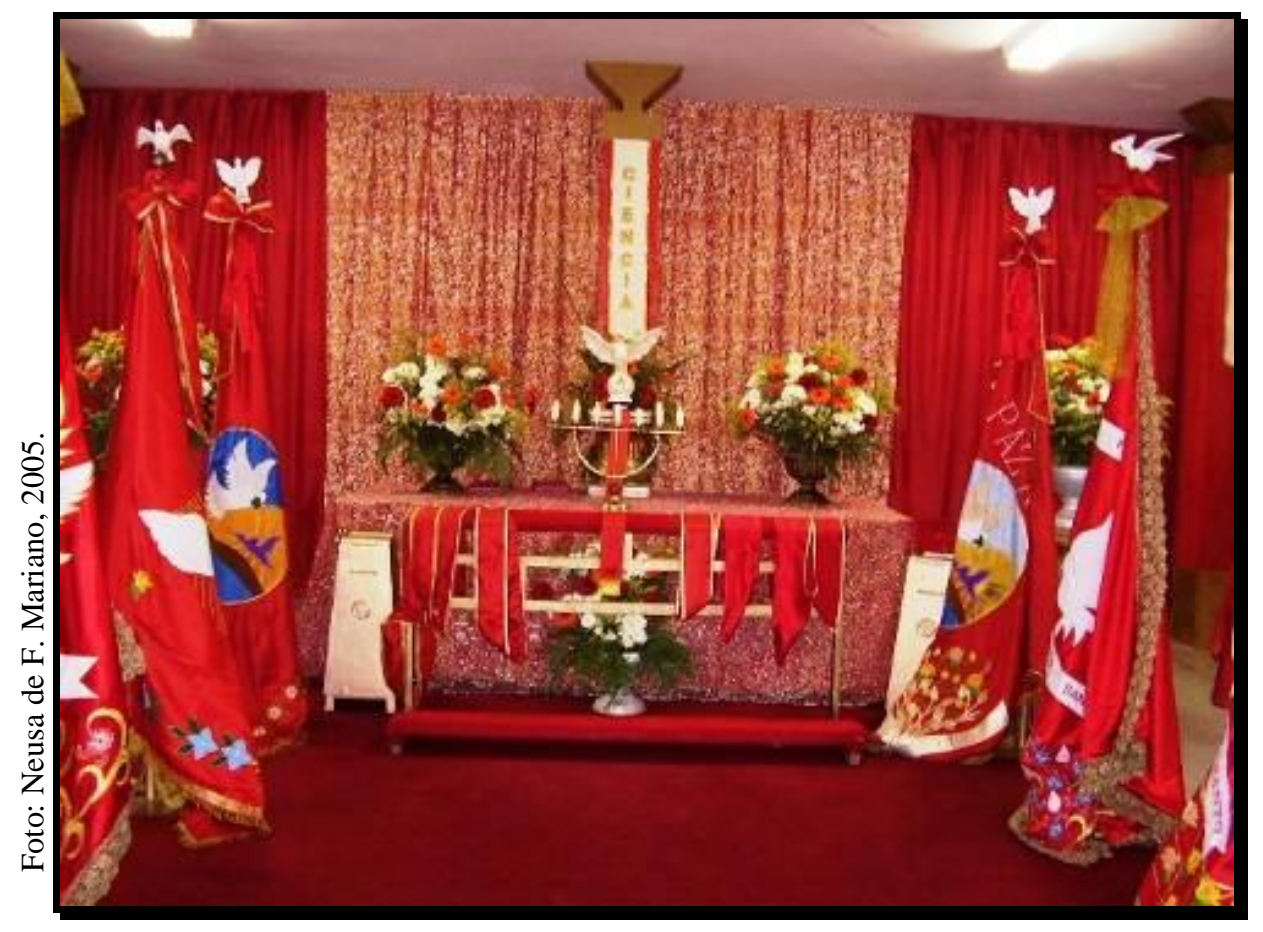

Império do Divino, no salão da igreja de Santa Cruz, em Biritiba Ussu.

Foto 62.

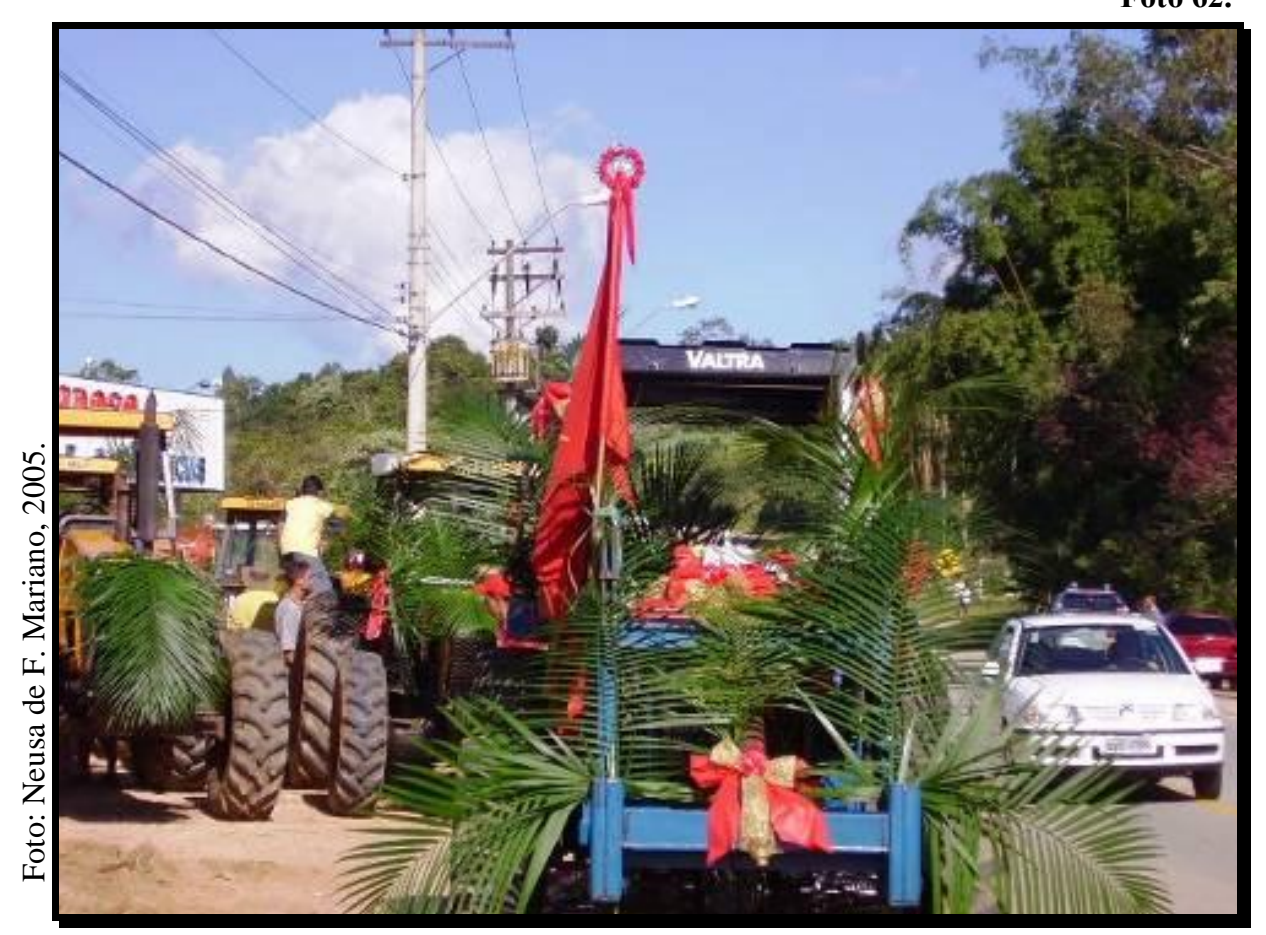

Entrada dos Palmitos, com o primeiro trator trazendo a imagem do Divino, a Pomba Branca.

\section{pdfMachine}

A pdf writer that produces quality PDF files with ease!

Produce quality PDF files in seconds and preserve the integrity of your original documents. Compatible across

nearly all Windows platforms, simply open the document you want to convert, click "print", select the

"Broadgun pdfMachine printer" and that's it! Get yours now! 
Foto 63.

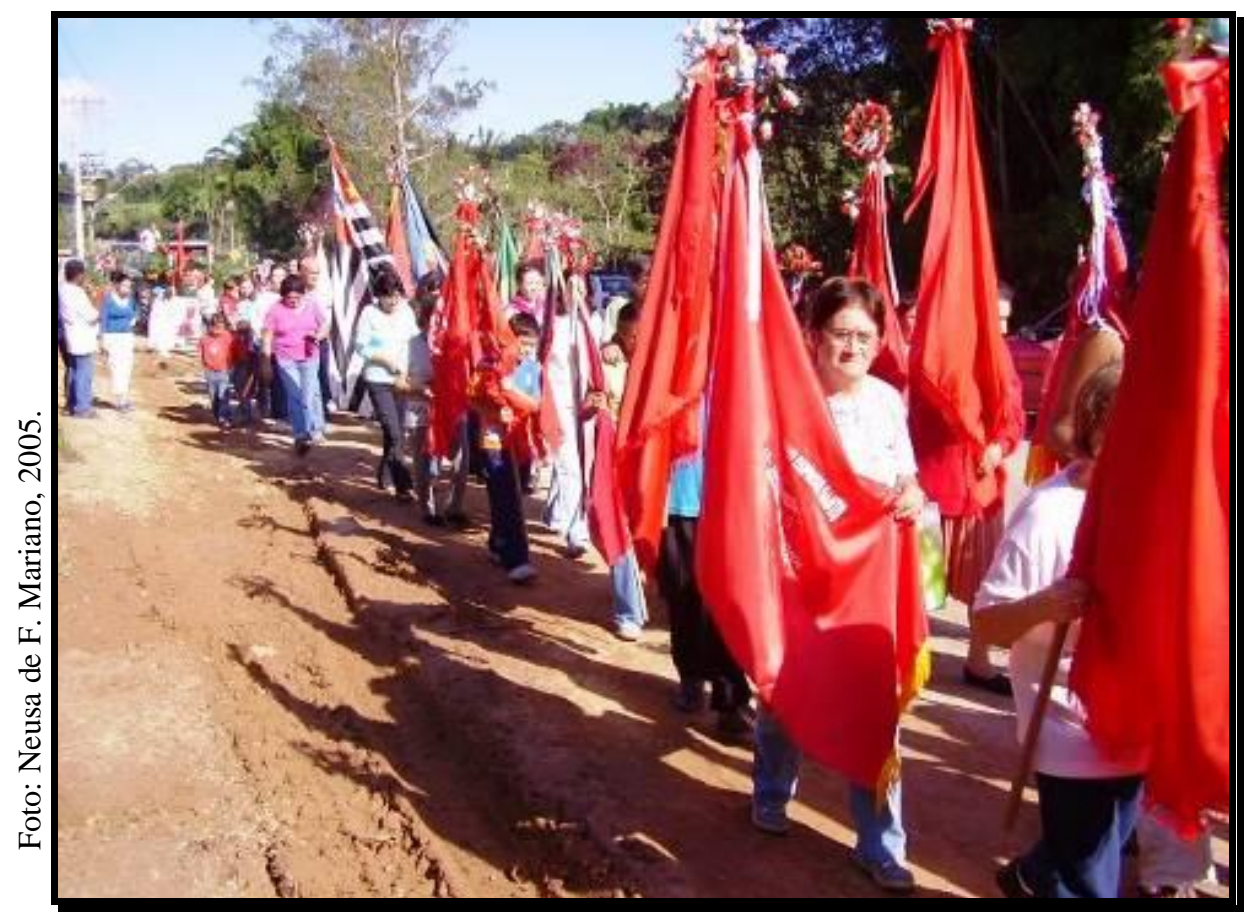

Devotos desfilam na Entrada dos Palmitos de Biritiba Ussu, portando bandeiras do Divino e seguem para a praça da igreja de Santa Cruz.

Foto 64.

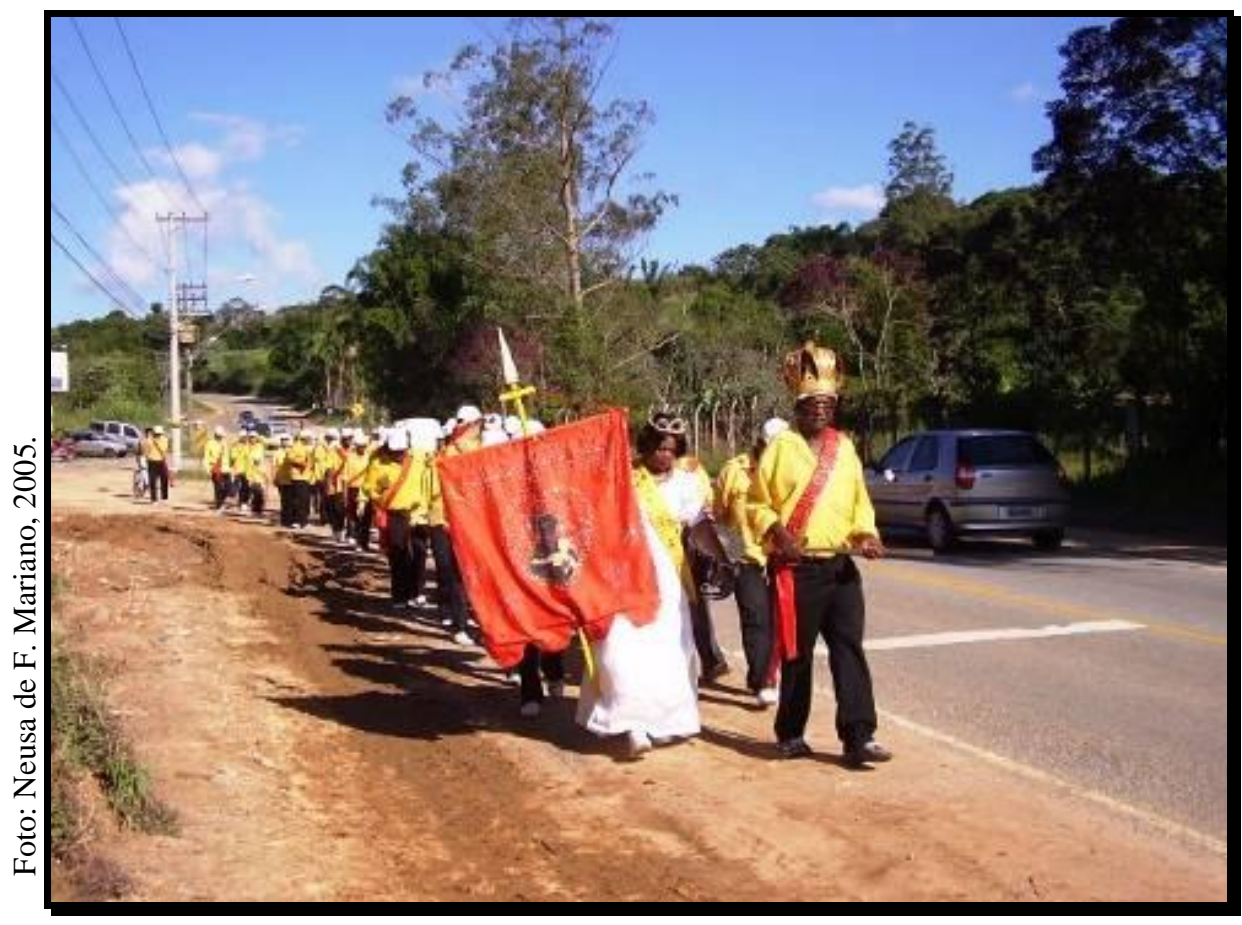

Eu já senti bem no fundo mesmo, porque eu ia segurar aquela bandeira - como Deus me iluminou e São Benedito falou para eu segurar a bandeira, para prestar serviço para eles -, eu senti uma honra muito grande, que hoje, graças a Deus, tenho muita fé.

Sebastiana. Rainha da Congada de São Benedito.

\section{pdfMachine}

A pdf writer that produces quality PDF files with ease!

Produce quality PDF files in seconds and preserve the integrity of your original documents. Compatible across

nearly all Windows platforms, simply open the document you want to convert, click "print", select the

"Broadgun pdfMachine printer" and that's it! Get yours now! 
Já no distrito de Cezar de Souza, a festividade é realizada desde $1970^{167}$. Em 2005, a Festa do Divino ${ }^{168}$, estava centralizada na igreja de São Benedito, que abrigava o Império do Divino (Foto 65). O levantamento do Mastro ocorreu um mês antes da Festa acontecer, seguido de uma Novena do Espírito Santo. Acompanhada pela Folia do Divino de Biritiba Ussu, a Alvorada ocorreu apenas no primeiro domingo da Festa do Divino, depois da qual foi servido café aos participantes, a exemplo da Festa de Mogi das Cruzes. Neste mesmo dia, ainda pela manhã, houve a Procissão dos Cavaleiros e distribuição do Afogado. No último dia da Festa, no domingo seguinte, a igreja de São Benedito de Cezar de Souza ficou totalmente ocupada pela população daquele distrito, durante a Missa de Encerramento. Na seqüência, todos participaram da Procissão de Pentecostes (que não ocorreu no dia de Pentecostes, oficialmente), com a presença dos Festeiros, dos Capitães de Mastro de Cezar de Souza, dos Imperadores do Divino (Foto 66), da Congada de São Benedito, e do Padre que acabara de celebrar a missa. Devotos carregavam os andores do Divino, de São Benedito e de Nossa Senhora de Fátima; todos seguiam pelas ladeiras do pequeno núcleo urbano, onde moradores humildes observavam a procissão.

Próximo à igreja de São Benedito, o tapete ornamental, feito de serragem era percorrido, primeiramente pelo Padre e só depois, pelos devotos. Ao término da Procissão, de volta à igreja, o Padre anunciou os nomes dos novos Festeiros, que escolheriam os Capitães de Mastro do ano seguinte. Em seguida, a Congada de São Benedito fez uma apresentação em frente à igreja, inclusive com músicas de Luiz Gonzaga, uma homenagem do Mestre Chico Preto. A Quermesse, instalada logo em frente à igreja de São Benedito era constituída por barracas simples, sem qualquer padronização (pescaria com prendas, caixassurpresas, bingo, doces, salgados e bebidas). Alguns ambulantes se fixaram junto às barracas da Quermesse, talvez de comum acordo com os organizadores da Festa e com a igreja; talvez para aproveitar a aglomeração eles, de repente, apareceram.

${ }^{167}$ Conforme o Sr. Chico Preto, Mestre da Congada de São Benedito. 
Há cerca de trinta e sete anos, a Festa do Divino Espírito Santo é realizada no distrito de César de Souza.

O Império é montado no interior da igreja e apreciado pelos devotos

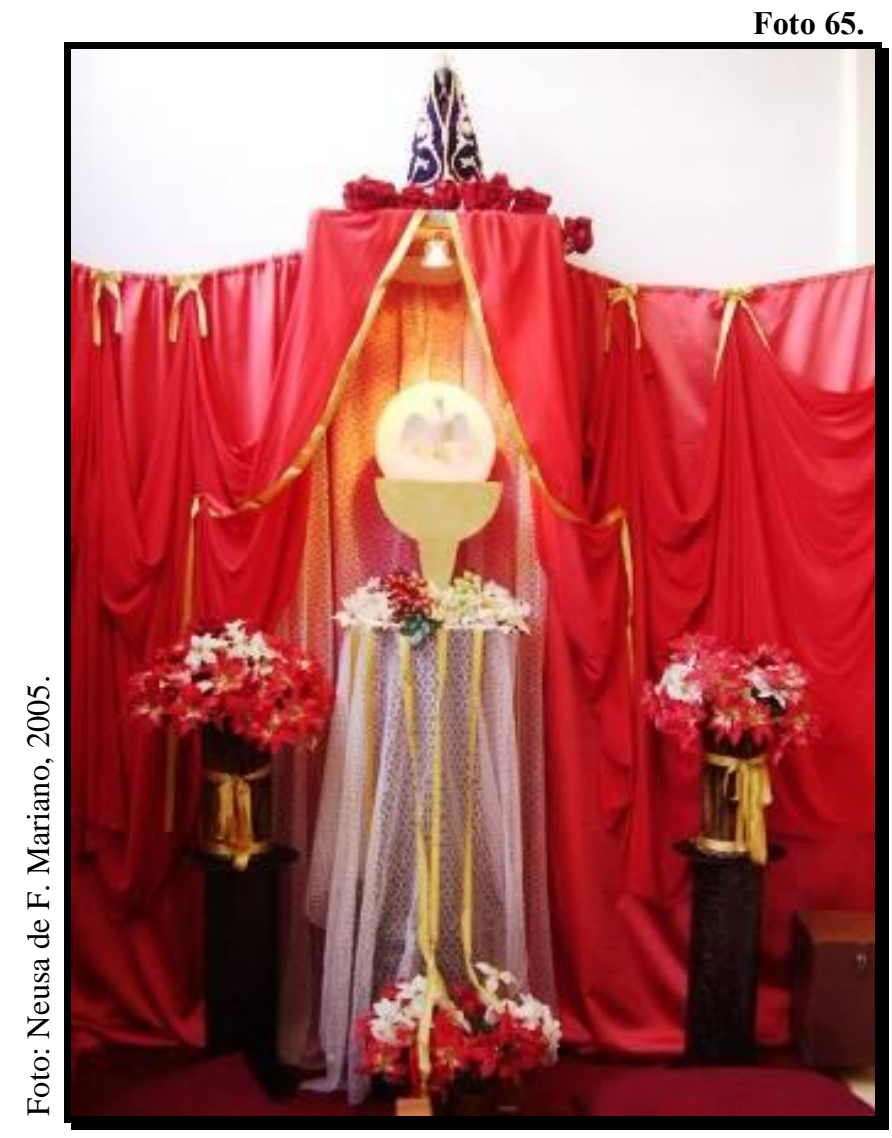

Foto 66.

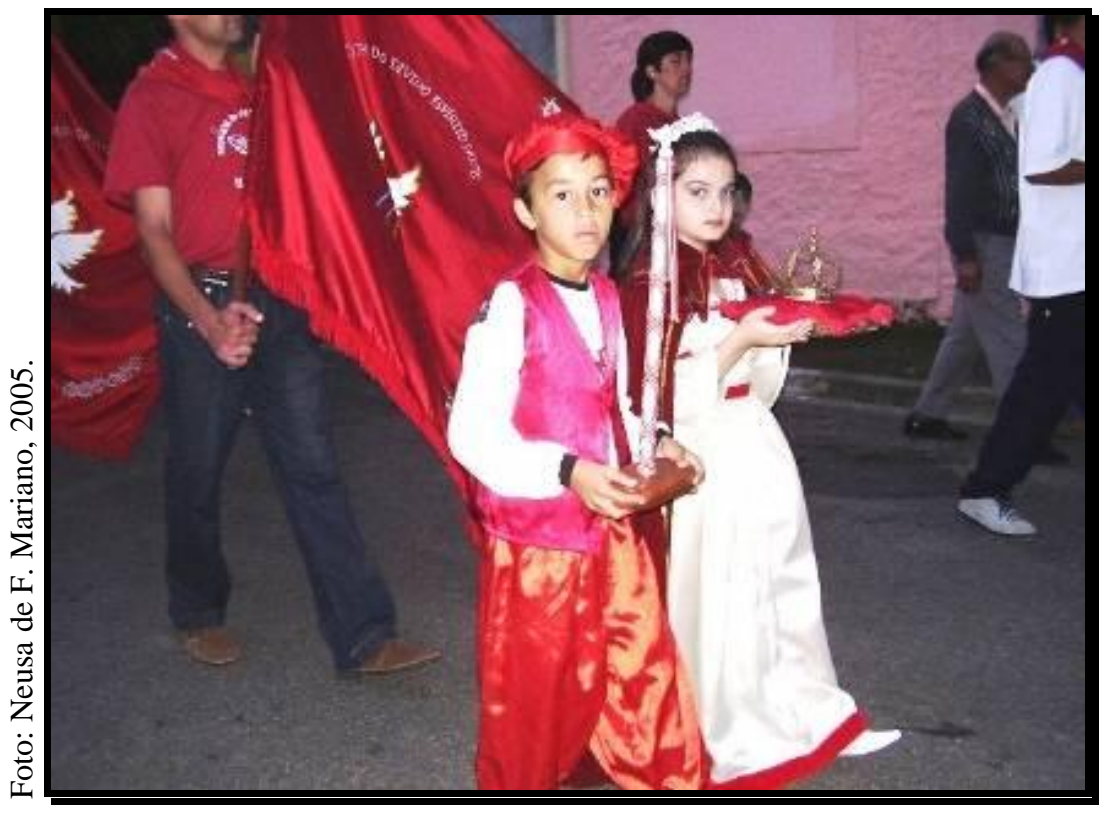

Na Procissão de

Pentecostes, crianças participam representado o Imperador e a Imperatriz do Divino, carregando o cetro e a coroa.

${ }^{168}$ Conforme informações no cartaz de divulgação da Festa do Divino Espírito Santo de Cezar de Souza e observações feitas durante o último dia de Festa que, no ano de 2005 realizou-se de 01 a $05 / 05$

\section{pdfMachine}

A pdf writer that produces quality PDF files with ease!

Produce quality PDF files in seconds and preserve the integrity of your original documents. Compatible across nearly all Windows platforms, simply open the document you want to convert, click "print", select the "Broadgun pdfMachine printer" and that's it! Get yours now! 
O cartaz de divulgação da Festa do Divino Espírito Santo de Sabaúna, realizada de 02 a 12 de junho de 2005, indicava ser aquela a $12^{\text {a }}$ Festa realizada no distrito. Segundo Dona Terezinha, moradora de Sabaúna, a Festa existe há cerca de vinte anos. Deduz-se que a Festa do Divino, apenas pode ter deixado de ser realizada em um ano ou outro, e a de 2005 tenha sido a $12^{\mathrm{a}}$, realizada ininterruptamente.

O primeiro dia da Festa (quinta-feira) foi marcado pela concentração de bandeiras do Divino na casa dos Capitães de Mastro, seguindo em procissão até a igreja de São Sebastião de Vila Mathias onde ocorreu o levantamento do Mastro e, logo após, uma missa. É nesta igreja que se encontrava o Império do Divino Espírito Santo ${ }^{169}$. Durante a semana, à noite, rezava-se a missa da Novena na referida igreja.

No sábado à noite, a concentração de bandeiras se deu na casa dos Festeiros e seguiu de lá até a igreja de Nossa Senhora do Carmo, onde a Novena foi encerrada. No domingo aconteceu a Alvorada a partir de 6:00h da manhã que, diferente da de Mogi das Cruzes, não era uma procissão, os devotos soltando rojões, cada qual em sua casa. Às 7:00h começou a ser servido o café com biscoito para a população em geral e, às 9:00h iniciou-se a missa dominical, celebrada do lado de fora da igreja de São Sebastião, por ser esta muito pequena. A Procissão de Pentecostes ${ }^{170}$, com o andor da Pomba que representa o Divino Espírito Santo, teve início logo após a missa (Fotos 67 e 68), e contou com a participação da Banda Santa Cecília (de Mogi das Cruzes); da Congada Santa Efigênia ${ }^{171}$; de crianças da catequese que, vestidas com túnicas vermelhas, carregavam pequenos estandartes que traziam escrito, cada qual, um dom do Espírito Santo; Festeiros e Capitães de Mastro; o Padre; cavaleiros (cerca de duzentos); um carro de boi, e cerca de cinqüenta charretes (Fotos 69 e 70). A Procissão, tendo à frente os fogueteiros, passou sobre o Tapete Ornamental (Foto 72), feito de serragem, cujos desenhos representam os dons do Divino Espírito Santo.

Ao chegar à igreja de Nossa Senhora do Carmo, os Festeiros e Capitães de Mastro passaram a missão da Festa do ano seguinte para os novos Festeiros e Capitães de Mastro, então escolhidos.

169 Também pode ocorrer de a Festa do Divino estar concentrada na igreja de Nossa Senhora do Carmo, localizada no centro de Sabaúna. Segundo Dona Terezinha, a variação se dá de acordo com as comunidades que a organizam.

${ }^{170}$ Assim como em Cezar de Souza, não era oficialmente dia de Pentecostes.

${ }^{171}$ O mesmo grupo participa da Festa do Divino de Mogi das Cruzes, oriundo do distrito de Braz Cubas 
Após a solenidade foi distribuído o Afogado, acompanhado de arroz e salada, para a população ${ }^{172}$. Para evitar que as pessoas ficassem muito tempo na fila do Afogado, durante a procissão foram distribuídas senhas configurando a prioridade para os que dela participassem. A Quermesse ${ }^{173}$ (montada na rua principal de Sabaúna, próximo à antiga estação de trem), que geralmente funciona à noite, somente neste dia estava em pleno funcionamento desde a manhã, devido ao grande movimento da Procissão de Pentecostes e distribuição do Afogado.

Também aconteceram, à noite, shows com duplas caipiras e violeiros, sobre um palco, montado na Quermesse para este fim. Às 21:00h de domingo terminou a Festa do Divino de Sabaúna, com a queima de fogos.

A Festa de Sabaúna tem algumas semelhanças com a Festa de Mogi das Cruzes: o Tapete Ornamental, o carro de bois, charretes e cavaleiros, só que aqui, durante a Procissão de Pentecostes, já que não há Entrada dos Palmitos na programação.

Festa do Divino mais singela é a realizada no Bairro de Itapeti ${ }^{174}$, pela Comunidade de Santo Alberto. Com uma população dispersa em sítios, a capela de Santo Alberto (pertencente à Paróquia Rural de São Bento do Parateí), constitui a centralidade para o bairro rural de Itapeti (Fotos 73 e 74), onde acontece a Festa em apenas um domingo. Iniciase com o levantamento do Mastro e a Missa, pela manhã, seguida de distribuição do café aos presentes. À tarde é rezado um terço antes da Procissão de Pentecostes (assim como nos outros distritos, não é oficialmente dia de Pentecostes), com a presença do grupo de Moçambique de Santa Isabel (município vizinho de Mogi das Cruzes). À noite acontece a Quermesse no pátio da igreja, com leilão, bingo, churrasco, bebidas, etc.

A Festa do Divino, também realizada no distrito de Taiaçupeba, ocorreu no mesmo período da Festa de Mogi, em 2005, impossibilitando, desta forma, o seu acompanhamento.

${ }^{172}$ Cada pessoa deveria levar seu próprio prato e talheres ou então, comprá-los no local, pois os organizadores da Festa estavam vendendo estes utensílios descartáveis por R $\$ 1,00$.

${ }^{173}$ Segundo Ana, moradora de Sabaúna, as pessoas que montaram barracas na Quermesse, pagaram à igreja $\mathrm{R} \$ 20,00$ (vinte reais) pelo espaço. Parece não ter havido muito critério com relação aos produtos vendidos, pois havia tanto barracas de artigos típicos de quermesse (vinho quente, quentão, churrasco, doces, etc.) como barracas de brinquedos e CDs.

${ }^{174} \mathrm{O}$ acesso ao Bairro de Itapeti é dificultado em razão da reduzida freqüência dos ônibus urbanos que servem à localidade. As informações foram obtidas através de cartaz de divulgação da Festa do Divino de Itaneti realizada em $05 / 06 / 2005$ 


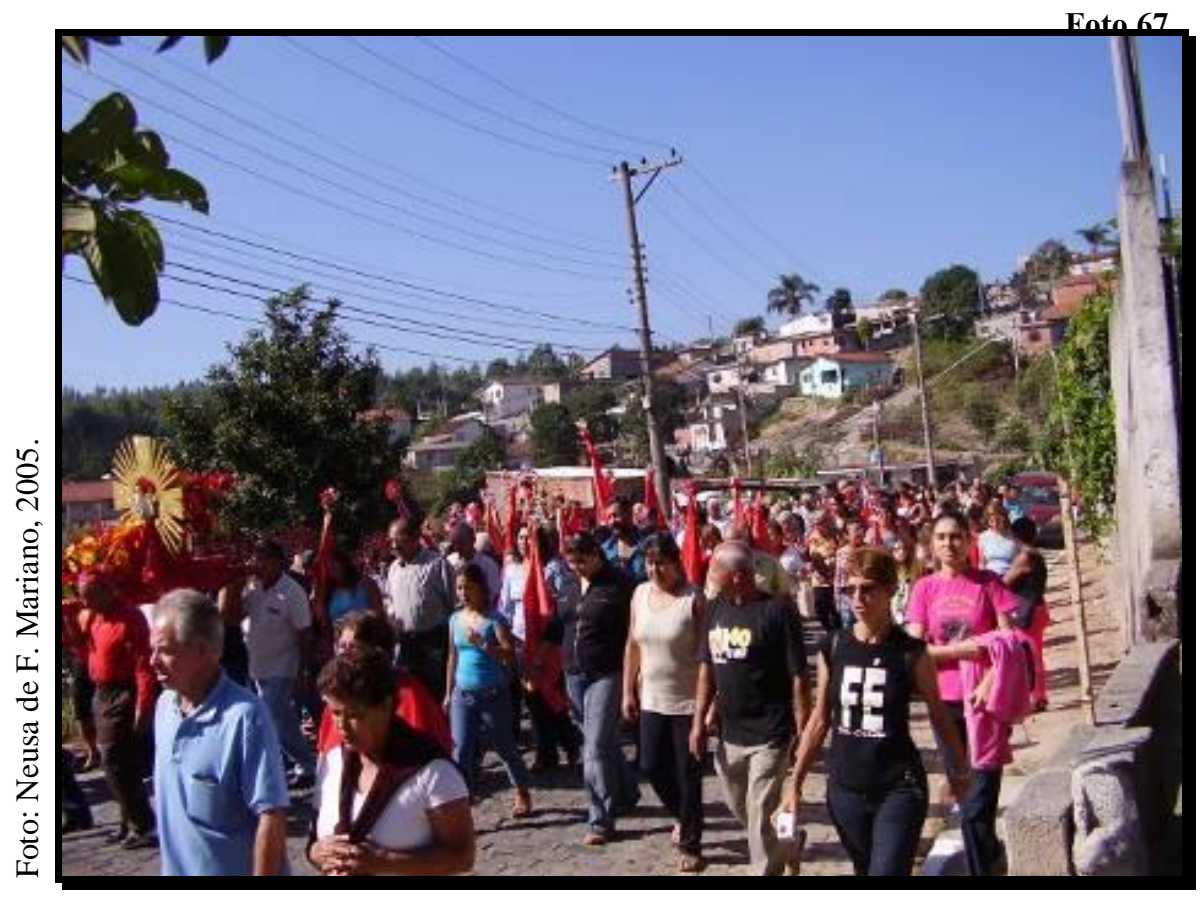

Embora não seja grandiosa quanto a de Mogi das Cruzes, a Festa do Divino de Sabaúna reúne muitos fiéis durante a Procissão de Pentecostes.

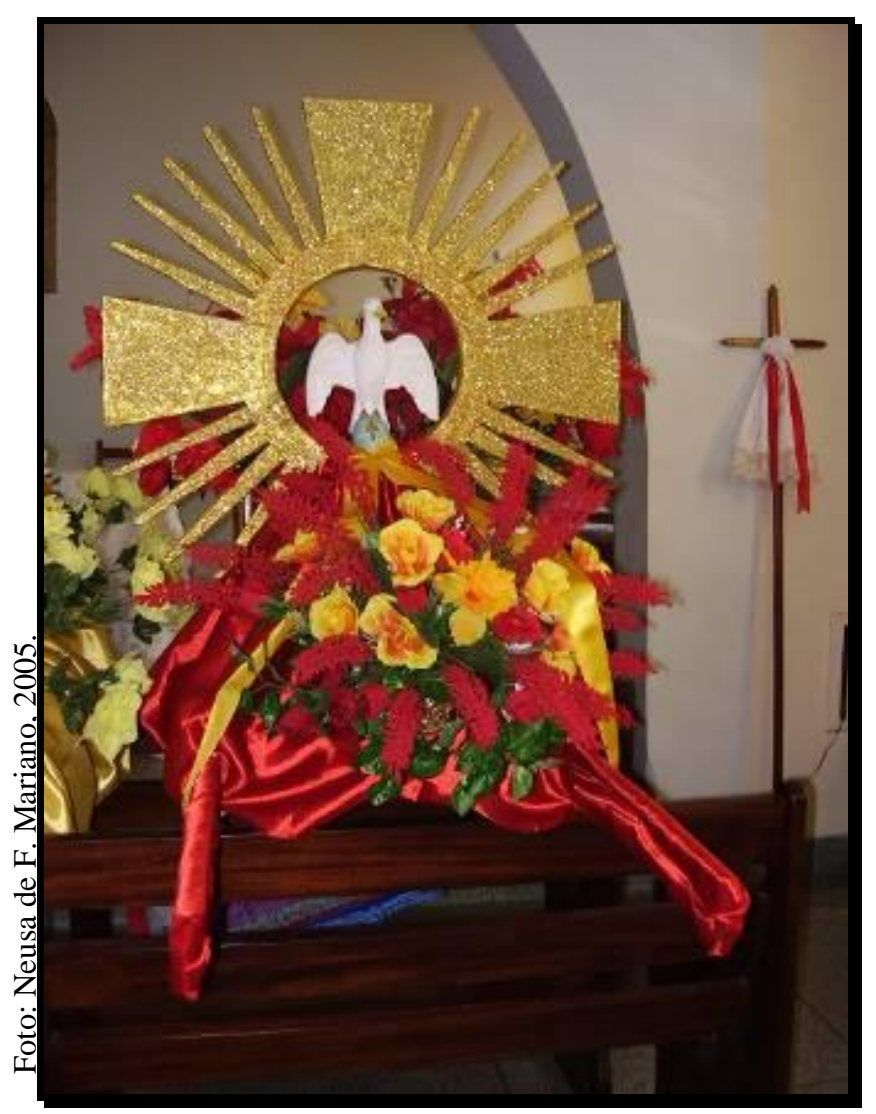

Foto 68.

Andor do Divino Espírito Santo que, após percorrer as ruas de Sabaúna, repousa na Igreja de Nossa Senhora do Carmo daquele distrito.

\section{pdfMachine}

A pdf writer that produces quality PDF files with ease!

Produce quality PDF files in seconds and preserve the integrity of your original documents. Compatible across nearly all Windows platforms, simply open the document you want to convert, click "print", select the "Broadgun pdfMachine printer" and that's it! Get yours now! 


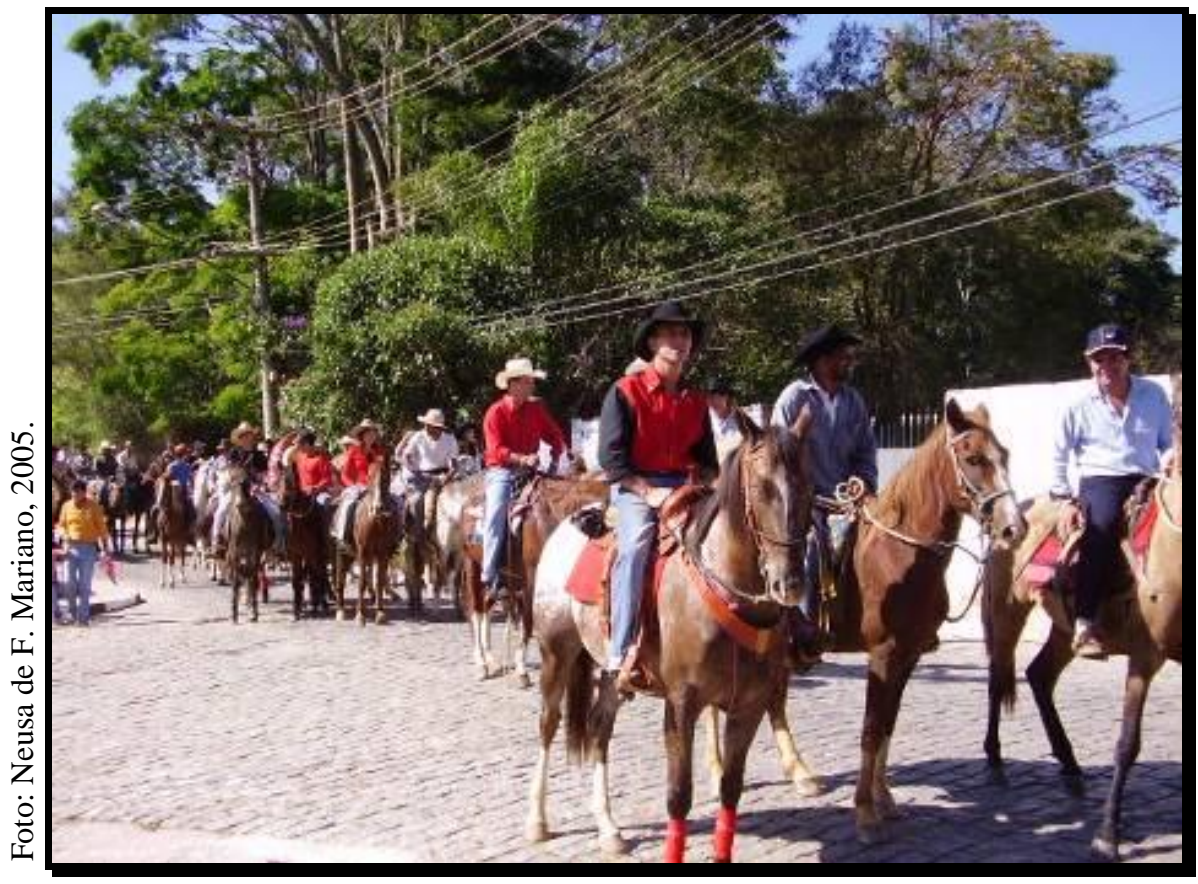

A Procissão de Pentecostes de Sabaúna conta com as homenagens dos cavaleiros, vindos da zona rural.

Foto 70.

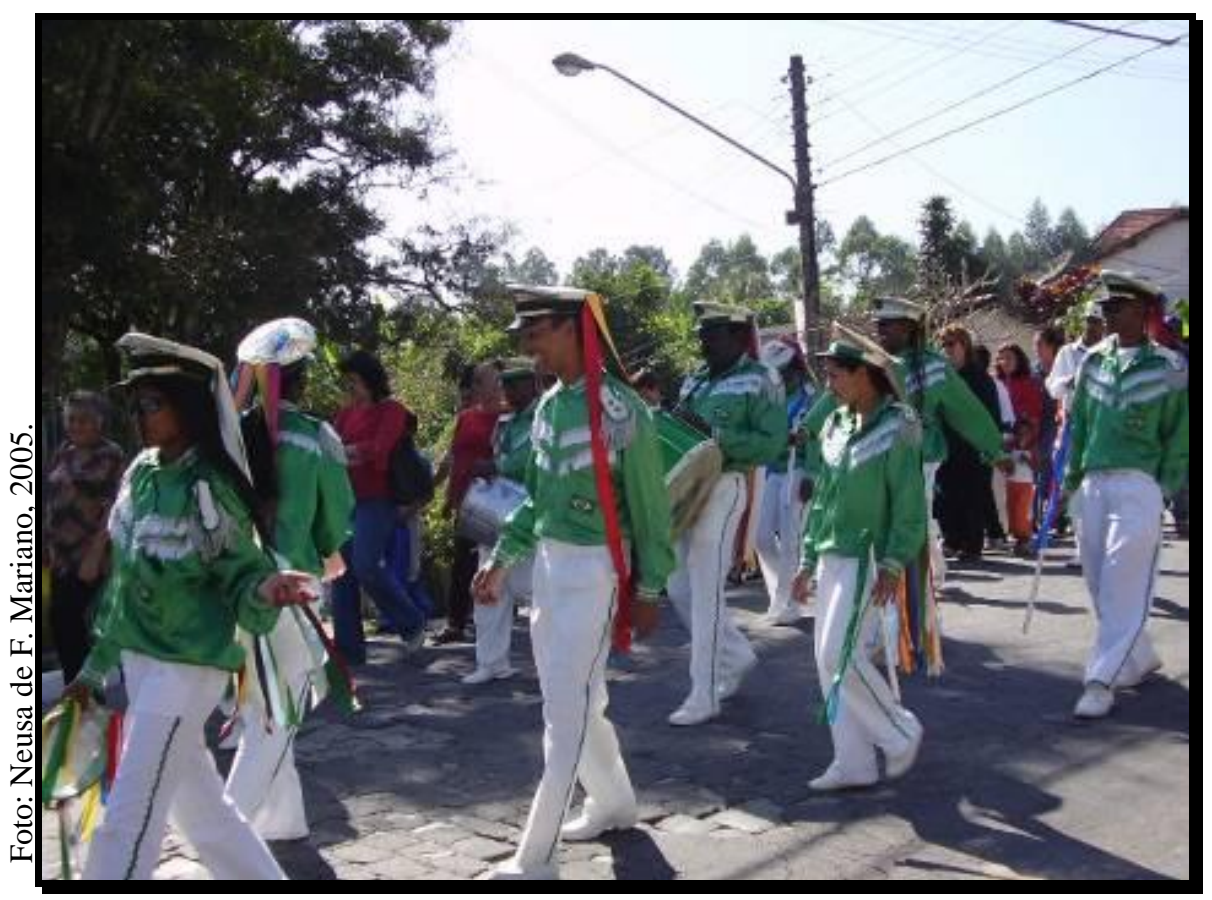

Presença fundamental para os festejos de Pentecostes é a de um Grupo de Congada, no caso, da Congada de Santa Efigênia na Festa do Divino de Sabaúna.

\section{pdfMachine}

\section{A pdf writer that produces quality PDF files with ease!}

Produce quality PDF files in seconds and preserve the integrity of your original documents. Compatible across nearly all Windows platforms, simply open the document you want to convert, click "print", select the 


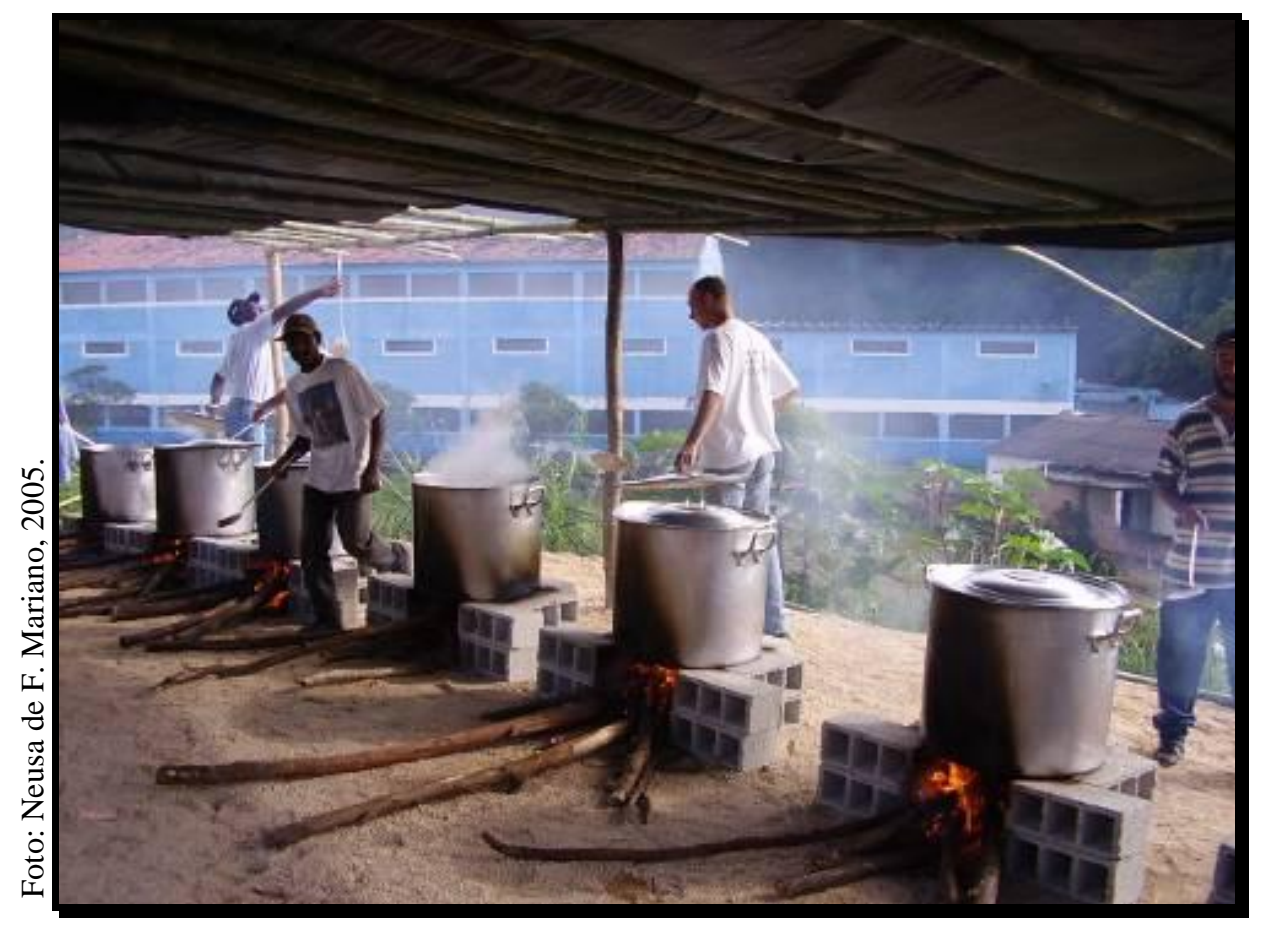

A incumbência de preparar o Afogado, que será distribuído à população logo após a Procissão de Pentecostes, fica, em Sabaúna, reservada aos homens.

Foto 72.

A confecção do Tapete Ornamental, feito com pó de quartzo colorido e serragem, também tornou-se prática quase indispensável na Procissão de Pentecostes.

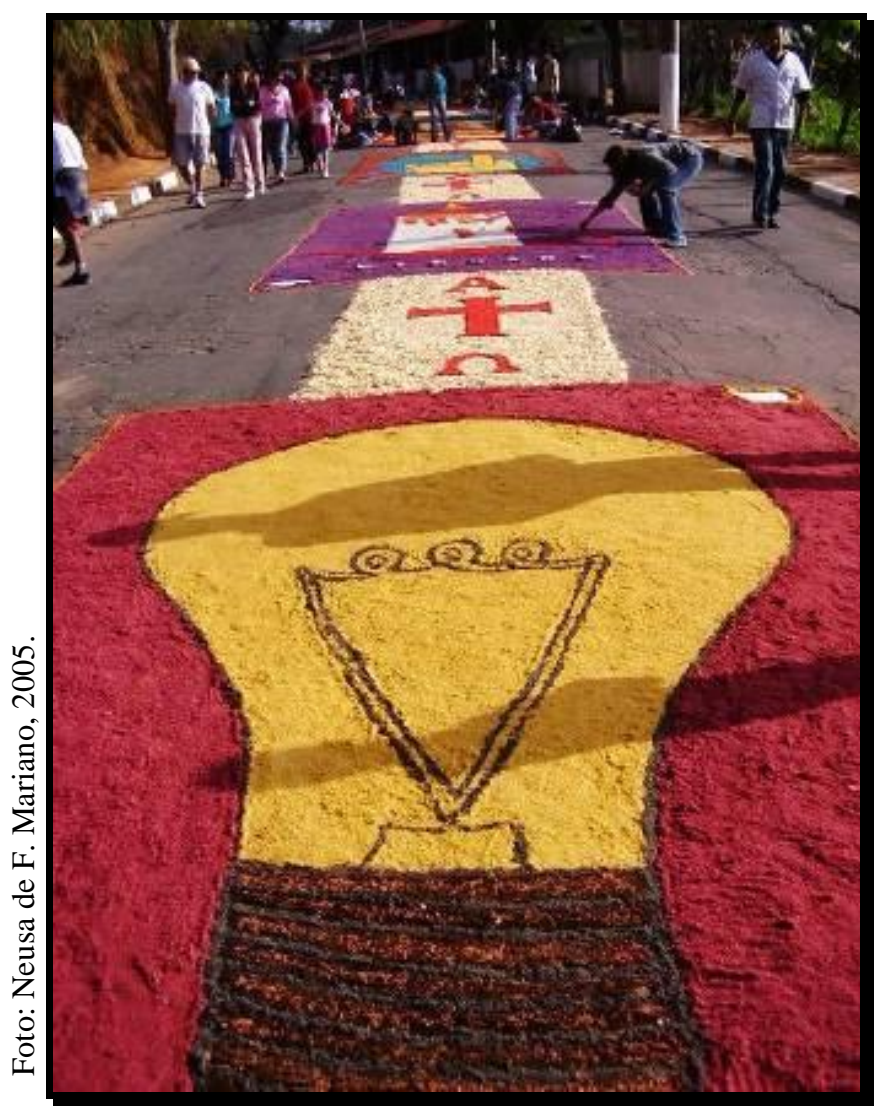

\section{pdfMachine}

A pdf writer that produces quality PDF files with ease!

Produce quality PDF files in seconds and preserve the integrity of your original documents. Compatible across nearly all Windows platforms, simply open the document you want to convert, click "print", select the "Broadgun pdfMachine printer" and that's it! Get yours now! 


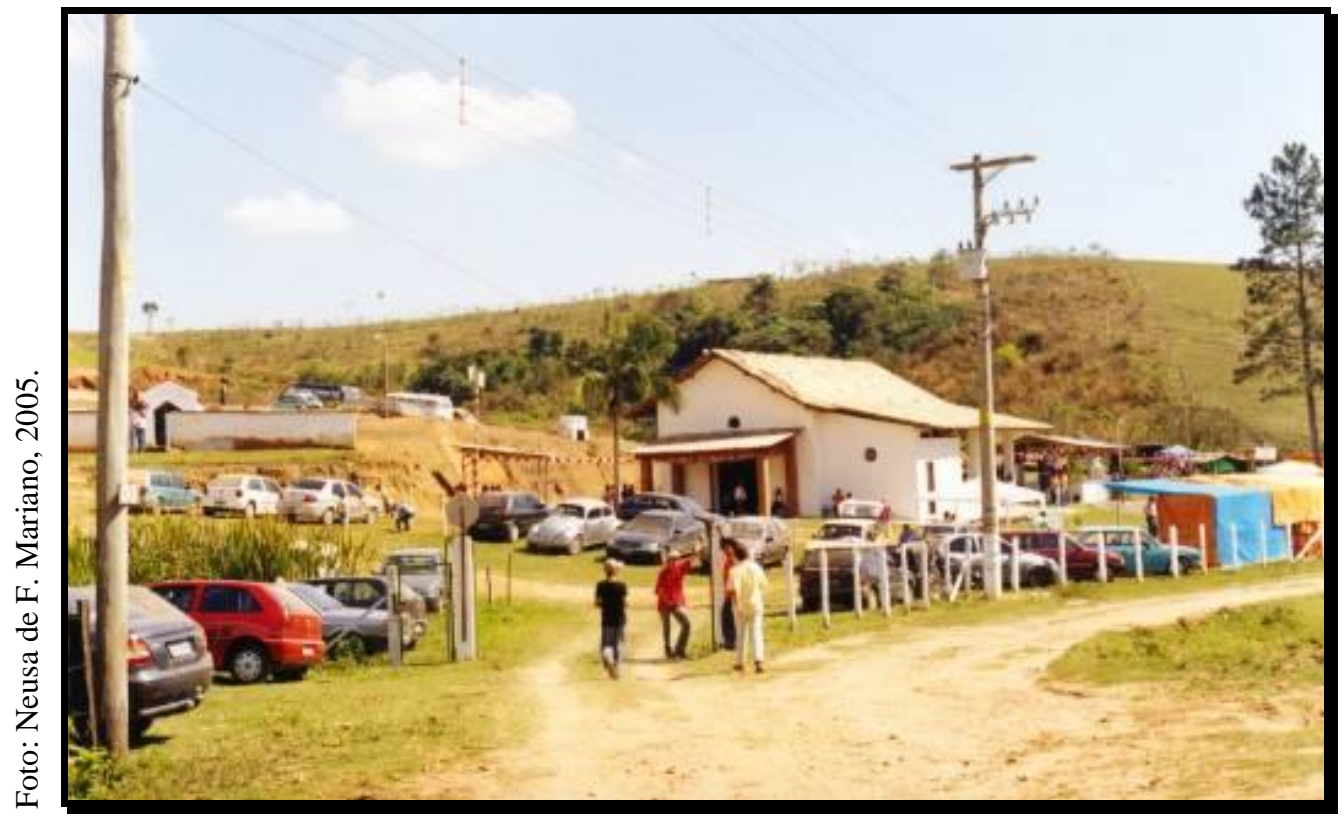

Foto 74.

Igreja de Santo Alberto, fundada no século XVII, no Bairro de Itapeti.

Os festejos, na ocasião, eram em homenagem a Santo Alberto.

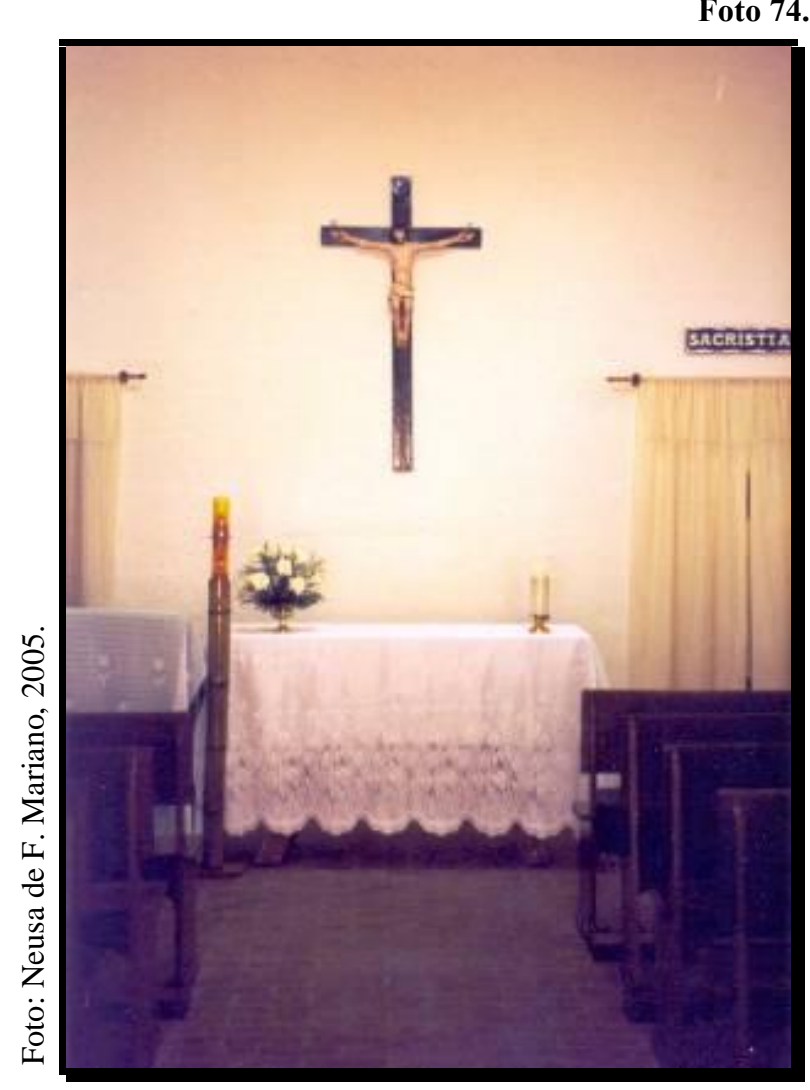

pdfMachine

A pdf writer that produces quality PDF files with ease!

Produce quality PDF files in seconds and preserve the integrity of your original documents. Compatible across nearly all Windows platforms, simply open the document you want to convert, click "print", select the "Broadgun pdfMachine printer" and that's it! Get yours now! 
O atual Bispo Diocesano de Mogi das Cruzes tem incentivado a realização de Festas do Divino Espírito Santo (sem ostentações) em todos os bairros do município. Nas festividades brevemente descritas, pudemos constatar algumas semelhanças com as atividades promovidas durante a Festa do Divino de Mogi das Cruzes: tapete ornamental, Entrada dos Palmitos, Afogado, Passeata das Bandeiras, Alvorada e Café... Portanto, a Festa de Mogi parece ser o modelo de Festa do Divino seguido pelos organizadores das Festas menores, apesar da antiguidade de algumas delas.

A Associação Pró-Festa do Divino, que não atua nas Festas dos distritos, é apontada como fonte de orientação aos organizadores, mais inexperientes, das Festas menores. O risco, segundo Caíque (um dos coordenadores da Associação), está na possível confusão frente aos patrocinadores/apoiadores da Festa do Divino de Mogi das Cruzes, que podem não mais reconhecer os representantes da Festa de Mogi, e negociar com as Festas dos distritos. Isso geraria uma concorrência entre as Festas do Divino, na captação de recursos.

Eu acho que está criando demais festas do Divino, tem muita festa do Divino. Em Mogi, eu mapeei [...] eu não sei se são nove ou se são onze, dentro de Mogi. Não tem condição! Aí começa uma a descaracterizar a outra. Daqui a pouco vai descaracterizar a maior. E é dificil. Eles têm o respeito, querem procurar a gente, tem dica, mas todos eles vêm aqui: "Como eu posso fazer minha festa melhor? Como que eu posso fazer para ser tradicional e diferente daqui? Como é que eu capto patrocinio? Quanto é que eu arrecado mais de dinheiro?" Todos eles vêm perguntar a mesma coisa para mim. E isso me deixa chateado, me deixa preocupado. Não vêm pelo aspecto de Festa, vêm pela arrecadação, o que é uma realidade, mas eu me preocupo com isso. (Caíque).

Outra dificuldade está na ornamentação e figurino de anjos, quando organizadores das Festas menores buscam apoio junto à Associação Pró-Divino, como expõe Salete, uma coordenadora de ornamentação:

O Dom Airton quis que todos os bairros passassem a ter Festa do Divino durante o ano. Então muita gente vem pedir pra gente roupa emprestada. Olha, é o que eu falo: "-Infelizmente, não". Não é por má vontade, mas se você empresta para um... são muitos bairros. Então aquele lava, lava, lava, lava... quando nós chegamos no fim, nós não temos. E nós não temos patrocínio nem para criar alguma coisa, nós temos que preservar o que nós temos. Senão, de um ano para outro, nós ficamos sem. Porque já são roupas compridas que arrastam [as roupas dos anjos usadas na Procissão de Pentecostes], você tem que lavar, você enrosca aqui, você pisa ali. E se for feito semanalmente, quinzenalmente porque são várias festas, de um ano para o outro, nós ficamos sem... [...] Acho que a parte da ornamentação é uma parte que tem sido, assim, tanto quanto ingrata nesse 
sentido, porque é dificil da gente adquirir alguma coisa. Para estragar, estraga fácil. A gente faz artesanalmente, tem flores que a gente compra pronta na 25 de Março [em São Paulo]. Tem muita coisa que a gente faz artesanalmente. Se você destrói, você não repõe. Faixas, flâmulas, colunas, se você empresta, volta quebrado, ninguém repõe. Então são coisas que a gente tem titubeado em emprestar porque, você faz as flâmulas pra igreja... some uma, estraga, queima, desaparece, já desfalca.

O trabalho de confecção artesanal das flores e outros adereços é feito a partir de trabalho voluntário, sob a coordenação de Salete e Sérgio Vicco, que também decoram o Império do Divino e o interior da Catedral de Santana durante a Festa. Atualmente, o Bispo tem solicitado simplicidade nas ornamentações, inclusive na Catedral, que passou a ser decorada de forma singela, com flores naturais.

Parece que a preocupação com o "patrimônio" material da Festa, sob a guarda da Associação Pró-Divino não chama a atenção do Sr. Josemir, pois ele acredita que a PróDivino possa auxiliar os organizadores das Festas menores, com o fornecimento de material. Para ele, a proliferação de Festas do Divino em Mogi das Cruzes é resultado do crescimento da Festa Maior, principalmente no que diz respeito ao trabalho de evangelização, como também aponta o Sr. Mathias:

Eu acho bom [ter Festas do Divino nos distritos], porque difunde esse espirito. Uma das funções, uma das coisas que a gente quer é a evangelização do fiel, do católico. E essa festa traz essa evangelização, $e$ tem as missas aonde é feita a homilia. E eu acho importante.

As Festas do Divino nos distritos tendem a reproduzir a Festa de Mogi, muitas vezes pelo fato de os seus agentes serem os mesmos, voluntários na Festa Maior. Assim há acesso às receitas de comes e bebes, aprendizado de rituais, contatos com empresas... Enfim, a própria Festa de Mogi que se tornou tão grande e precisa de tantos voluntários possibilita que estes se tornem agentes mais visíveis nas Festas de seus bairros, levando o conhecimento adquirido em Mogi das Cruzes. Uma relação que, para os organizadores da Festa de Mogi, deveria ser de mão única. Pessoas dos distritos podem ajudar na Festa de Mogi, mas o inverso parece não agradar muito aos organizadores da Festa Maior.

A Festa do Divino, como tradição, tem sido incorporada cada vez mais à lógica do mercado, uma vez que entra no calendário turístico do município de Mogi das Cruzes e recebe, conseqüentemente, turistas vindos dos municípios próximos. Mas a visibilidade da festa se dá graças à Associação Pró-Festa do Divino que a promove, institucionalizando-a. Haveria aqui, o "monopólio da tradição", pois a Associação não é questionada quanto ao 
modo de organização do evento, ela simplesmente o realiza, com o respaldo dos Festeiros, da Igreja e do poder público municipal, ou seja, é reconhecida como órgão que faz a Festa acontecer.

Uma vez fortalecida (enquanto espetáculo) e enfraquecida (enquanto manifestação espontânea), a Festa se expandiu pelos distritos de Mogi das Cruzes. Mesmo com postura oposta, querendo afirmar a Festa como tradicional, a "verdadeira", alguns distritos (ex.: Biritiba Ussu), reconhecem a perda de costumes pretéritos da Festa e o avanço da comercialização na mesma. Há, portanto, uma "reinvenção da tradição" da Festa nos distritos de Mogi das Cruzes, como a Entrada dos Palmitos de Biritiba Ussu com os tratores no lugar dos carros de bois, ou ainda, como a presença de charretes e cavaleiros na Procissão de Pentecostes em Sabaúna.

Mesmo dentro da Festa Maior há acontecimentos festivos de forma espontânea que quebram com as relações existentes entre as instituições realizadoras da Festa do Divino (a Associação, a Igreja, a Prefeitura, etc.). Estes momentos sutis, imperceptíveis às vezes (que podem se manifestar na forma como o devoto paga a sua promessa ao Espírito Santo, ou ainda, na esperança de vida melhor, com a vinda do Espírito Santo, através da observância dos rituais) tendem a romper com a espetacularização da Festa e o seu sentido de mercadoria, havendo uma restituição da Festa enquanto manifestação da cultura popular. 


\section{CONSIDERAÇÕES FINAIS}

Eu sinto de fato a presença divina, que é uma energia que eu não sei explicar com detalhes. Mas é uma energia que faz você ter coragem de realizar as coisas. Faz você ter coragem de enfrentar as dificuldades.

Caíque

A utopia de Joaquim de Fiore, que anuncia a chegada da Era do Espírito Santo é renovado a cada ano, através das festividades de Pentecostes, numa manifestação religiosa, sobretudo, popular. Espera-se pelo tempo em que a caridade, a solidariedade, o amor, a esperança e a justiça, reinarão no mundo em que vivemos.

Em Portugal do século XIV, homenagens festivas ao Espírito Santo eram realizadas por vontade da rainha Dona Isabel que coroava um mendigo, transformando-o em imperador por um dia. Ao lado da coroação do "imperador", os "vodos" eram praticados, caracterizando uma festividade com fartura e ostentação, já que era uma festa da realeza. A sua realização não partia do povo, mas era para o povo: coroação de um membro do povo e distribuição de alimentos aos pobres. Mesmo por um curto espaço de tempo, havia, nas festividades, uma "inversão", em que o poder passava, aparentemente, para as mãos de um novo imperador, que dele usufruía, aplicando-o sobre assuntos pré-determinados pelos verdadeiros imperadores.

Já no Brasil Império, o imperador do Divino era representado por alguém de posses (salvo exceções), sob autorização da Igreja mediante pagamento de taxa para a realização da 
Festa. Quem a organizava eram as Irmandades do Espírito Santo, em conjunto com a elite que a ela era afiliada, mantendo o caráter de festa da realeza, com ostentação (ABREU, 1999). No início do século XX não seria tão diferente, pois a escolha do imperador (criança ou adulto) recaía sobre a família que pudesse arcar com as despesas da comensalidade da Festa do Divino, além do pagamento de fianças para libertação de presos nas cadeias públicas. Assim, o poder de decisão sobre a sociedade mantém-se nas mãos da elite.

A Festa do Divino, neste período, era um momento para o encontro, em que o devoto contribuía para a sua realização e participava dos festejos, de forma espontânea, mantendo o caráter de religiosidade popular. Uma dessas expressões populares está na atuação da Folia do Divino, que peregrinava pelos bairros rurais em nome do Espírito Santo e recolhia prendas (porcos, vacas, galinhas, e outros produtos da roça), garantindo a bênção do Espírito Santo sobre a família que os recebia, como sobre a colheita.

No caso de Mogi das Cruzes, o Bandeireiro era esse portador da mensagem e da bênção do Espírito Santo sobre a população. Outras formas de expressão popular em Mogi das Cruzes eram as danças de Congadas e Moçambiques, como também a realização da Entrada dos Palmitos.

Com a Romanização, na segunda metade do século XIX, as festas populares enfraqueceram, porque as Irmandades perderam poder. Como promotoras de manifestações consideradas profanas, foram alvo de um trabalho de moralização por parte da Igreja. Contribuiu, também, para a decadência das festas de cunho religioso popular a posição anticlerical por parte da elite, que associava o catolicismo ao atraso, fazendo-se divulgar o aspecto negativo da festividade: a Festa era vista como estímulo à vagabundagem; as barracas de comes e bebes das festas contribuíam para a falta de higiene; e ainda, tais barracas poderiam desencadear a violência porque eram pontos de aglomeração. Com o advento da República ocorreu um maior cerceamento das manifestações religiosas populares, enfraquecendo-as principalmente nas cidades; elas iam sendo realizadas em locais cada vez mais distantes (ABREU, 1999), com características cada vez mais populares. Alimentando um catolicismo rústico, portanto, as festas religiosas passaram a ter fortes contornos populares, com pouca ou nenhuma importância ao caráter ostentatório, mas mantendo o seu sentido mais forte enquanto manifestação da cultura popular. 
Lembremo-nos das Festas do Divino realizadas, no município de Mogi das Cruzes, pelo Sr. Aquino já em meados do século $\mathrm{XX}^{175}$, quando a vida ainda girava muito em torno do calendário litúrgico. Estas festas aconteciam paralelas às Festas oficiais da cidade de Mogi das Cruzes. A Festa, que durava dias, com rezas dirigidas por um capelão, configurava-se numa manifestação espontânea da população, com muita comida, bebida e dança; a Festa era vivida pelos devotos em todos os seus sentidos: preparação conjunta, partilha, solidariedade, identidade, fé e alegria.

Em meados século XIX ${ }^{176}$, a representação do Imperador do Divino ${ }^{177}$, sobre quem recaía a responsabilidade pelo sucesso da Festa, cedeu lugar ao "Festeiro", como foi designado nos registros de Provisões do Arquivo da Cúria Metropolitana de São Paulo.

Na primeira metade do século XX, em Mogi das Cruzes, o Festeiro já não era mais aquele que arcava com todo o gasto da Festa sozinho, mas contava com o auxílio financeiro de devotos, principalmente os da elite da cidade. Assim, circulava o Livro de Ouro, uma maneira mais formalizada de arrecadação de prendas e recursos para a Festa do Divino. Fábricas e estabelecimentos comerciais começaram a ser contatados para auxiliar a Festa, o que lhes proporcionava status social. Devotos continuavam contribuindo, e seus nomes, assim como os das fábricas, também eram registrados no Livro de Ouro.

Com o processo de industrialização e urbanização pós II Guerra Mundial, a cidade de Mogi das Cruzes cresceu, provocando o enfraquecimento das relações próximas (de vizinhança, de compadrio, de amizade, com base no sentimento de confiança). Este enfraquecimento também é revelado pelos entrevistados, que dizem manter relações de confiança com seus vizinhos mais antigos, o que confere a Mogi das Cruzes o "espírito" de cidade pequena; já em novas relações que se estabelecem (de vizinhança, de clientela...), a impessoalidade domina.

${ }^{175}$ Segundo Eulália, filha do Sr. Aquino, conforme já mencionado no Capítulo 4.

${ }^{176}$ Conforme ACMSP - Registros de Provisões, que datam do século XIX.

${ }^{177}$ A figura do Imperador do Divino ressurgiu em Mogi das Cruzes recentemente, em 1989. Assim, os dois personagens (Imperador e Festeiro) coexistem e, diferentemente do início do século XX (como relatou Oswald de Andrade), o Imperador é representado por uma criança escolhida pelo Festeiro, podendo ser seu parente, e tem a função de participar da Entrada dos Palmitos e da Procissão de Pentecostes, ao lado da Imperatriz do Divino, igualmente criança. Em alguns lugares, o Festeiro assume hoje a denominação de Imperador do Divino, como em Pirenópolis (GO), conforme Brandão (1978) e também em São Paulo na Freomesia do 
Não há a negação das relações próximas, mas uma observação referente ao seu enfraquecimento, diferente do que ocorria no passado, quando a economia tinha uma forte base rural.

$\mathrm{O}$ processo de industrialização leva à racionalização do cotidiano e à individualização, no espaço agora, fragmentado da cidade. A indústria, uma vez implantada nas cidades, provoca

[...] seu crescimento desmedido, mas com uma ruptura de suas características antigas (fenômeno de implosão-explosão). Com a indústria foi a generalização da troca e do mundo da mercadoria que se produziu; o uso e o valor de uso desapareceram quase completamente só persistindo como exigência do consumo das mercadorias, o lado qualitativo do uso desaparecendo quase inteiramente. (LEFEBVRE, 1976: 67).

A apropriação do espaço pelo uso é negada pelo capital, ou seja, passa a haver a dissociação entre o homem e o espaço, através da mediação do mercado, e a própria cidade é transformada em mercadoria. As cidades são produzidas e vendidas na medida em que exploram e investem em suas tradições, suas histórias, seus monumentos, não da forma que permita a seus moradores apropriar-se delas, mas puramente como atrativo turístico com o objetivo de fazer movimentar a economia e ganhar status frente a outras cidades.

Na década de 1970, artigos do jornal O Diário de Mogi já anunciavam, ainda que timidamente, o turismo que a Festa do Divino Espírito Santo poderia proporcionar à cidade, incentivando e fazendo com que se intensificasse seu caráter espetacular. Em 1985, a Festa do Divino foi incluída no calendário turístico do município, com o intuito de "não deixar a Festa acabar”. Era esta uma forma de incentivar a população a realizá-la, visto que naquele período faltavam casais que a assumissem como Festeiros. A estratégia de parte da elite, era utilizar atrativos "pitorescos", tendo as Congadas e os Moçambiques como elementos centrais, por serem considerados "folclóricos"; o incentivo se dava no âmbito do discurso de "preservar" a cultura do povo, considerado o bem cultural que resiste à urbanização. Cabe aqui um parêntese para a observação de Bosi (1987: 123), de que a cultura popular não precisa ser "conservada", mas sim, o povo que a origina. Enquanto existir povo, existirá cultura popular.

Nesse processo de transformação de Festa em produto a ser consumido, a Entrada dos Palmitos que, antes, tinha relação direta com o vivido, passa a ser um cortejo organizado para atender interesses de determinados grupos locais. Nesse sentido, as ruas são interditadas e as rotas alternativas são divulgadas nos meios de comunicação, a fím de não 
provocar transtornos aos usuários; autoridades municipais se vêm ao lado de Festeiros e Capitães de Mastro carregando bandeiras do Divino; Paróquias são representadas pelas crianças da catequese e pelos grupos da comunidade; grupos de Congada e de Moçambique continuam se apresentando, só que agora, têm direito a pequeno "cachê" ou ajuda de custo, embora, segundo entrevistas, este não seja o fator determinante de sua participação; a população rural da região (com charretes e carros de bois) recebe toda a assistência ao chegar para a Entrada dos Palmitos, uma vez que é convidada pela Associação. Vai-se perdendo o sentido espontâneo da participação popular numa tendência à reinvenção do tradicional, pois o cortejo agrega tudo o que pode ser considerado folclórico, mesmo que haja elementos, hoje, que não façam parte do passado da Festa, o passado que se quer preservar. Terminado o cortejo, as ruas são imediatamente limpas, sem deixar vestígios do ocorrido, a fim de interferir pouco na "ordem urbana".

Nesse sentido, a Festa do Divino e, sobretudo, a Entrada dos Palmitos, transforma as ruas da cidade em palco, com as calçadas tomadas por expectadores, atraídos pelo espetáculo ali realizado, onde a aparência parece ter ganhado importância exacerbada. Para Debord (1997: 18), quando a aparência ganha contornos fundamentais, é porque a vida social está tomada pelo espetáculo, subordinada aos "resultados acumulados da economia".

Para garantir a tradição, a Festa, aos poucos vai se tornando mercadoria, através da venda de quotas de patrocínio às empresas de Mogi das Cruzes e região, a partir do surgimento da Associação Pró-Festa do Divino, que hoje auxilia os Festeiros na sua realização, de forma racionalizada. As empresas apoiadoras da Festa ganham notoriedade, através dos folhetos e cartazes de divulgação, e da mídia. A diretoria da Associação, por sua vez, entende que seu papel é justamente preservar a tradição da Festa e, para isso, contrapõe-se a algumas condições impostas por possíveis patrocinadores: não é em todo lugar que se pode colocar o logotipo da empresa patrocinadora. A Bandeira do Divino, a Entrada dos Palmitos, a Procissão de Pentecostes, o Tapete Ornamental são intocáveis neste sentido; não é qualquer empresa que pode patrocinar, pois prevalece o bom senso (os Festeiros de 2006 negaram o apoio de uma empresa que queria instalar um aterro sanitário na cidade). 
O caráter espetacular da Festa domina, também, a Quermesse, gerenciada pela Associação Pró-Divino, embora auxilie entidades filantrópicas ${ }^{178}$. Acontece que o comércio que neste momento festivo se estabelece, é fundamental, pois o lucro torna-se importante na medida em que é usado para pagamento de serviços que contribuem para a transformação da Festa em espetáculo. Na Quermesse, os patrocinadores da Festa são mencionados frequentemente pela Divina Rádio, no mesmo instante em que shows, festivais de música sertaneja e apresentações dos grupos de Congada e Moçambique acontecem no palco. Distante da igreja (a centralidade principal da Festa), a Quermesse organiza uma outra centralidade que atrai não só devotos, mas é uma forma de a Festa ser mostrada também a um público que não freqüenta a "parte religiosa". Além da separação entre o religioso e o folclórico na programação da Festa do Divino, há a separação do espaço físico da Quermesse (em alguns momentos considerados folclóricos) que, com o objetivo de atender à demanda do público, precisa ser montada em espaço amplo. E ainda, na Quermesse é possível visualizar a aparente "inversão", pois a igualdade social ali parece ser estabelecida. Voluntários em algumas barracas são, muitas vezes, profissionais liberais da cidade: arquitetos, advogados, médicos, delegados, professores, políticos, etc., e trabalham juntamente com pessoas menos abastadas ${ }^{179}$, com funcionários (públicos ou não) que são, compulsoriamente, "voluntários" na Quermesse ${ }^{180}$. Aparentemente, estabelece-se uma condição de igualdade, desaparecem as diferenças de classes, nestes momentos de servir à Festa. Esta aparência, no entanto, se desfaz através da imprensa, por exemplo, que destaca a elite que "humildemente" trabalha voluntariamente na Festa, obtendo assim, automaticamente, status. Esse é o retorno do voluntário (pessoa física ou jurídica): reconhecimento social, o que não deixa de ser espetáculo, numa sociedade em que tudo pode ser transformado em mercadoria, inclusive a própria imagem.

Na realidade, conforme Queiroz (1992: 154), ocorre uma dissimulação, através das representações coletivas, das estruturas e valores sociais:

[...] estruturas e valores permanecem os mesmos durante sua realização [do carnaval]; somente ficam escondidos sob o véu do entusiasmo e da efervescência desencadeados pelas representações coletivas que compõem

${ }^{178}$ Conforme já mencionado no Capítulo 5, as entidades ficam com $75 \%$ do lucro que obtiveram em suas barracas, com a venda de doces, salgados e bebidas durante a Quermesse.

${ }^{179}$ Algumas pessoas encontram no trabalho voluntário da Festa do Divino uma forma de agradecer ao espírito Santo por graças alcançadas.

180 Conforme relatow informalmente uma funcionária destas emnresas 
a imagem da festa. Nenhuma modificação, nenhuma inversão palpável aparece, nem nas estruturas e na organização da coletividade da festa, nem em seus valores profundos, que continuam governando os comportamentos. (QUEIROZ, 1992: 154).

Assim, a Festa do Divino Espírito Santo de Mogi das Cruzes reproduz as contradições da sociedade, as diferenças sociais e econômicas. A Igreja, através do Bispo Diocesano, busca seus fiéis, atraídos pelas atividades da Festa, e, atualmente, freia a ostentação, incentiva a realização da Festa pelos diversos bairros de Mogi das Cruzes, esperando a intensificação de seu caráter religioso. Os organizadores destas festas de bairro, por seu turno, se espelham na Festa do Divino de Mogi, cuja estrutura é montada pela Associação através da divisão do trabalho, em vista da grande dimensão que a Festa tomou nos últimos anos.

Assim, como revelou a pesquisa realizada por Brandão (1978), a Igreja respeita, mas desprestigia o "lado profano" dos festejos, tentando deslocar para a tradição da Festa, o aspecto mais religioso; as autoridades civis e as empresas, ao contrário, privilegiam os rituais "folclóricos", centrando a Festa nos momentos mais atrativos aos turistas, aos curiosos, ao mercado; os "[...] agentes da Festa [devotos] trabalham no sentido de preservar o que consideram 'suas tradições', para eles o motivo quase único pelo qual ainda tem sentido repeti-la todos os anos.” (BRANDÃO, 1978: 45).

A forma como é feita essa "preservação da tradição", pelos organizadores, no caso de Mogi, pela Associação Pró-Divino, é aquela sob o domínio do capital. A espetacularização da Festa não pode ser entendida como um fato dissociado do contexto urbano-industrial, do processo de modernização.

Moradores mais antigos de Mogi das Cruzes já não reconhecem a cidade como um todo, pois pontos de referências deram lugar a novos bairros, alguns deles, de alto padrão. Lembram os entrevistados da bica d'água, dos quintais grandes, da criação de vacas nos pastos onde se ia buscar e tomar leite, das brincadeiras nas ruas que hoje fazem parte do centro da cidade, dos domingos festivos, dos dias de missa, etc. Diante da nova configuração da cidade de Mogi das Cruzes, que se estendeu aos bairros antes rurais, Festeiros e Capitães de Mastro têm a oportunidade, em função da Festa do Divino, de conhecer áreas mais periféricas e as rurais, onde incentivam seus moradores a conhecerem o centro da cidade, num contato mais próximo com a festividade. A Festa se perde na fragmentação da cidade, uma vez que ela própria se fragmentou. 
A própria Festa do Divino, nas proporções que tomou, torna-se inapreensível na sua totalidade, no seu sentido mais profundo para os Festeiros, preocupados em administrála.

A Festa se moderniza, ao se atualizar no processo de urbanização, mas mantém elementos do seu passado, os quais emergem no período festivo e, mesmo antes dele. No cotidiano acelerado do processo de modernização dominado pelo capital, o tempo lento de uma sociedade agrária ainda persiste, um tempo não capturado pelo mercado, pelo capital. Pode-se falar em temporalidades diversas num mesmo tempo e espaço social, caracterizado pela simultaneidade de práticas de tempos históricos pretéritos e atuais, muitas vezes presentes nas representações, como as manifestações populares de caráter religioso tradicional. Assim, a ruralidade se faz presente no espaço urbano. Segundo Martins (2002: 221)

“[...] o rural pode subsistir culturalmente por longo tempo fora da economia agrícola. Pode subsistir como visão de mundo, como nostalgia criativa e autodefensiva, como moralidade em ambientes moralmente degradados das grandes cidades [...].

Continua o autor, dizendo que a visão de mundo permeada pela ruralidade configura-se como uma transição que permanece, porque é inconclusa, simultânea ao tempo da sociedade urbano-industrial, que a nega no seu processo de modernização.

No caso estudado, pode-se falar da ruralidade no urbano expressa na fartura, representada pelos alimentos, expostos e distribuídos em vários momentos: a distribuição do Afogado é um dos, senão o, momento mais significativo da comensalidade, que reúne centenas de pessoas para se alimentarem de algo que, para muitos, é sagrado. A força do alimento não está só nos seus ingredientes, mas no seu poder reconfortante e na refeição realizada em conjunto. No mesmo sentido, a distribuição do café da Alvorada, em que os devotos, após se alimentarem de orações, fazem, de forma coletiva, a primeira refeição do dia, para eles, abençoada. Outros momentos em que o alimento está presente e é partilhado, estão nas Passeatas das Bandeiras, estão nas visitas das Rezadeiras antes da Festa, na charola em que os legumes e cereais que a compõem são distribuídos a instituições de caridade após a Entrada dos Palmitos, etc.

Podemos ainda mencionar, como ruralidade do urbano, a confecção artesanal de flores de tecido, feitas por voluntários uma a uma tempos antes do período da Festa, que 
servem de ornamentação para o Império e para o andor do Divino. O artesanato está presente também nos doces e salgados de variados sabores que são vendidos na Quermesse.

Ao mesmo tempo em que há uma grande organização da Festa do Divino de Mogi das Cruzes através da Associação Pró-Festa, com intensa e evidente divisão do trabalho, é importante para o devoto possuir bandeira do Divino, participar da Festa como voluntário e manifestar a sua religiosidade, transformando a organização de caráter empresarial da qual participa em nada mais que devoção, agradecimento, alegria. Há, neste sentido, uma tradução do espetacular para o popular que, transforma o espetáculo da Festa, em momento privilegiado de encontro, de reunião, de uma sociabilidade mais rica.

Por mais que a Festa do Divino seja um espetáculo assistido por curiosos, por turistas, por autoridades locais, etc., por mais que haja a divisão do trabalho, que se mantém ajustando a Festa ao processo de modernização, por mais que a Festa esteja fragmentada, ela é vivida no tempo livre por aqueles que se dedicam a ela em nome do Espírito Santo, sem esperar reconhecimento social em troca.

Conforme Canclini (1983: 54), a festa representa “[...] uma ocasião na qual a sociedade penetra no mais profundo de si mesma, naquilo que habitualmente lhe escapa, para compreender-se e restaurar-se". A Festa, neste sentido, aparece como ocasião de liberação das "amarras" impostas no cotidiano do trabalho produtivo. Extrai-se do interior das residências decoradas o ano inteiro com quadros e imagens do Divino, com bandeiras expostas nas salas de estar, além de lembrancinhas e medalhinhas do Espírito Santo, produzidas pela Associação, toda a força vital do popular, direcionada à Festa.

Lembrando Lefebvre (1958), o acontecimento festivo reúne todas as energias acumuladas no cotidiano que explodem na abundância (de ornamentações, de alimentos, de alegria). Os resíduos emergem na Festa, se mostram à sociedade que não se percebe de seu potencial transformador.

As energias acumuladas durante o período de não-festa se manifestam na disposição para as procissões noturnas e matinais, na Quermesse, no café da manhã, nas danças dos grupos de Congada e Moçambique, na Folia do Divino, enfim, em tudo o que é vivido na Festa, dando-lhe sentido.

"A cidade muda" - denunciam as entrevistas. "As pessoas mudam quando tem Festa do Divino, tornam-se mais solidárias. A cidade fica em clima de Festa". Essa 
“explosão de energia”, essa vitalidade, identificada pelos entrevistados como a própria presença do Espírito Santo, não é cooptada pelo capital.

Manifestam-se as possibilidades de transformação, na alegria coletiva, no estar em festa, mesmo esta espetacularizada. Essas possibilidades não significam retorno ao passado porque a Festa é tradicional, antes visam o que está por vir ou, como diz Bloch (2005: 2122), visam o "ainda-não-consciente", aquilo que "ainda não veio a ser", algo que ainda não se alcançou, o futuro que se almeja: o "lado voltado para frente". A intenção futura, para este autor, é utópica, visto ser sustentada pelo sonho "para frente".

A Festa do Divino Espírito Santo de Mogi das Cruzes manifesta esse potencial que alimenta a esperança de um mundo melhor. Os resíduos (da religião: vitalidade; da organização: o original, o "desviante"; da racionalidade: o natural; da mimèsis: a poèsis) ${ }^{181}$, se fazem presentes na Festa, através da cultura popular, mas "ainda-não-conscientes", ainda não compreendidos, separados que estão, diluídos no cotidiano e no espetáculo que tende (mas, trata-se de uma tendência) a destruir de a Festa.

181 Conforme Lefehvre $(1958 \cdot 68)$ 


\section{REFERÊNCIAS}

\section{Bibliografia}

ABREU, Marta. O Império do Divino: festas religiosas e cultura popular no Rio de Janeiro, 1830-1900. Rio de Janeiro, São Paulo: Nova Fronteira-Fapesp, 1999. 406 p.

ALMEIDA, Jaime. Revisitando São Luís do Paraitinga. Continuidades e rupturas. In: JANCSÓ, István; KANTOR, Íris (orgs.). Festa: cultura e sociedade na América Portuguesa. Vol. II. São Paulo: Hucitec, Edusp, Fapesp, Imprensa Oficial, 2001. p. 657-679.

ANDRADE, Mário de. A Entrada dos Palmitos. Revista do Arquivo Municipal. São Paulo, 1937, vol. 32. p. 51-64.

2002. 840 p.

Danças Dramáticas do Brasil. $2^{\mathrm{a}}$ ed. Belo Horizonte: Ed. Itatiaia,

ANDRADE, Oswald de. Um homem sem profissão: sob as ordens da mamãe. $2^{a}$ ed. São Paulo: Globo: Secretaria do Estado da Cultura, 1990. 133p.

ARANTES, Antonio Augusto. O que é cultura popular. São Paulo: Ed. Brasiliense, 1981. $83 \mathrm{p}$.

ARAUJO, Ana Maria R. Câmara. Festa do Divino e suas transformações na comunicação e na cultura. São Paulo: Andross, 2005.

AYALA, Marcos; AYALA, Maria Ignez Novais. Cultura popular no Brasil. Perspectiva de análise. $2^{\mathrm{a}}$ ed. São Paulo: Editora Ática, 1995. 77 p.

BÍBLIA. Mensagem de Deus. São Paulo: Editora Santuário; Edições Loyola, 1994. 1324 p.

BLOCH, Ernst. Formas remanescentes mais antigas do tempo livre, deturpadas, porém não sem esperança: hobby, festa popular, anfiteatro. In:

O Princípio Esperança.

Vol. II. Tradução de Werner Fuchs. Rio de Janeiro: EDUERJ: Contraponto, 2006. p. 459467.

Prefácio. In:

O Princípio Esperança. Vol. I.

Tradução de Nélio Shcneider. Rio de Janeiro: EDUERJ: Contraponto, 2005. p. 13-28.

BOSI, Alfredo. A cultura como tradição. In: BORNHEIM, G. et al. Cultura brasileira: tradição/contradição. Rio de Janeiro: Jorge Zahar, 1987. p. 112-137.

Cultura brasileira e culturas brasileiras. In:

Dialética da

Colonização. São Paulo: Cia. Das Letras, 1992. p. 308-345.

BOSI, Ecléa. Memória e sociedade. Lembrança de velhos. São Paulo: EDUSP, 1987. 402p.

BRANDÃO, Carlos R. O Divino, o Santo e a Senhora. Rio de Janeiro: Campanha de Defesa do Folclore Brasileiro: FUNARTE, 1978. 159 p. 
O que é folclore. $5^{\mathrm{a}}$ ed. São Paulo: Editora Brasiliense, 1985. 111 p.

Os caipiras de São Paulo. São Paulo: Ed. Brasiliense, 1983. 92 p.

Sacerdotes de viola. Rituais religiosos do catolicismo popular em São Paulo e Minas Gerais. Petrópolis: Vozes, 1981. 274 p.

BRUNO, Ernani da Silva. História e tradições da cidade de São Paulo. $4^{\mathrm{a}}$ ed. Vol. II Burgo de Estudantes (1828-1872). São Paulo: Hucitec, 1991.

CADASTRO INDUSTRIAL - 1965 - Estado de São Paulo, vol. VII - Tomo IV. São Paulo: IBGE, 1968.

CAMPOS, Jurandyr Ferraz. A Festa do Divino em Mogi das Cruzes. Mais de trezentos anos de fé e tradição. Mogi das Cruzes: Associação Pró-Festa do Divino Espírito Santo, 2001. 22 p.

CANCLINI, Nestor Garcia. As culturas populares no capitalismo. Tradução de Cláudio Novaes Pinto Coelho. São Paulo: Brasiliense, 1983. 149 p.

Culturas híbridas. $4^{\mathrm{a}}$ ed. Tradução de Heloísa Pezza Cintrão e Ana Regina Lessa; tradução da Introdução: Gênese Andrade. São Paulo: Edusp, 2006. 385p.

CANDIDO, Antônio. Caipiradas. In: Recortes. São Paulo: Companhia das Letras, 1993. p. 248-251.

Os parceiros do Rio Bonito: estudo sobre o caipira paulista e a transformação dos seus meios de vida. $7^{\mathrm{a}}$ ed. São Paulo: Livraria Duas Cidades, 1987. 372p.

CARLOS, Ana Fani Alessandri. Espaço-tempo na metrópole: a fragmentação da vida cotidiana. São Paulo: Contexto, 2001. 368 p.

CASCUDO, Luís da Câmara. Dicionário do Folclore Brasileiro. $11^{\mathrm{a}}$ edição. São Paulo: Global, 2001. 768 p.

Global, 2001. 111 p.

Mouros, franceses e judeus: três presenças no Brasil. $3^{\text {a }}$ ed. São Paulo:

CLAVAL, Paul. O Papel da Nova Geografia Cultural na compreensão da ação humana. In: ROSENDHAL, Zeny; CORREA, Roberto Lobato (orgs.). Matrizes da Geografia Cultural. Rio de Janeiro: Eduerj, 2001. p. 35-86.

CORREA, Roberto Lobato. Carl Sauer e a Escola de Berkeley - uma apreciação. In: ROSENDHAL, Zeny; CORREA, Roberto Lobato (orgs.). Matrizes da Geografia Cultural. Rio de Janeiro: Eduerj, 2001. p. 9-33.

DEBORD, Guy. A sociedade do espetáculo. Tradução de Estela dos Santos Abreu. Rio de Janeiro: Contraponto, 1997. 237 p.

DEBRET, Jean Baptiste. Viagem pitoresca e histórica ao Brasil. Tradução de Sergio Milliet. Tomo I, vol. II. São Paulo: Livraria Martins, 1940. 
DIAS, Madalena Marques. A formação das elites numa vila colonial paulista: Mogi das Cruzes (1608-1646). 2001. 167 p. Dissertação (Mestrado em História Social) Departamento de História, Universidade de São Paulo, São Paulo, 2001.

DUVIGNAUD, Jean. Festas e Civilizações. Tradução de C. F. Raposo Fontenelle. Fortaleza: Edições Universidade Federal do Ceará; Rio de Janeiro: Tempo Brasileiro, 1983.

ETZEL, Eduardo. Divino - simbolismo no folclore e na arte popular. São Paulo: Giordano; Rio de Janeiro: Kosmos, 1995. 180 p.

FAZENDA, Vieira. Antiqualhas e memórias da cidade do Rio de Janeiro. Revista do Instituto Histórico e Geográfico Brasileiro. Rio de Janeiro: IHGB, tomo 88, v. 142, p. 365-373. 1920.

FERLINI, Vera Lúcia Amaral. Folguedos, Feiras e Feriados: aspectos socioeconômicos das festas no mundo dos engenhos. In: JANCSÓ, István; KANTOR, Íris (orgs.). Festa: cultura e sociedade na América Portuguesa. Vol. II. São Paulo: Hucitec, Edusp, Fapesp, Imprensa Oficial, 2001. p. 449-463.

FERNANDES, Florestan. O folclore de uma cidade em mudança. In: OLIVEIRA, Paulo de Salles (org.). Metodologia das Ciências Humanas. São Paulo: Hucitec/UNESP, 1998. p. 53-80.

FESTA do Divino Espírito Santo 2002. Mogi das Cruzes: Associação Pró-Festa do Divino Espírito Santo, 2002. Relatório Final. 18 p.

FESTA do Divino Espírito Santo. Mogi das Cruzes: Associação Pró-Festa do Divino Espírito Santo, 2000. Manual Operacional. 34 p.

FREITAS, Afonso de. Tradições e reminiscências paulistanas. São Paulo: Itatiaia, 1985. Coleção Reconquista do Brasil, Nova Série. V. 92. 266p.

FRIEDMANN, Georges. O lazer e a civilização tecnicista. In: OLIVEIRA, Paulo de Salles (org.). O lúdico na cultura solidária. São Paulo: Hucitec, 2001. p. 115-130.

GEERTZ, Clifford. A interpretação das culturas. Tradução de Fanny Wrobel. Rio de Janeiro: Zahar Editores, 1978. 323 p.

GRINBERG, Isaac. Folclore de Mogi das Cruzes. São Paulo: Isaac Grinberg, 1983. 146 p. História de Mogi das Cruzes. São Paulo: Saraiva, 1961. 377 p.

1986. $181 \mathrm{p}$. Memória fotográfica de Mogi das Cruzes. São Paulo: Ed. Ex Libris, 1986. $181 \mathrm{p}$ $175 \mathrm{p}$. Mogi das Cruzes de 1601 a 1640. São Paulo: Isaac Grinberg, 1981. $240 \mathrm{p}$. Mogi das Cruzes de antigamente. São Paulo: Isaac Grinberg, 1964.

Retrato de Mogi das Cruzes. São Paulo: Isaac Grinberg, 1974. 233 p. pdfMachine A pdf writer that produces quality PDF files with ease!

Produce quality PDF files in seconds and preserve the integrity of your original documents. Compatible across nearly all Windows platforms, simply open the document you want to convert, click "print", select the "Broadgun pdfMachine printer" and that's it! Get yours now! 
Viajantes ilustres de Mogi das Cruzes. São Paulo: S.C.P., 1992. 176p.

GUARINELLO, Norberto Luiz. Festa, trabalho e cotidiano. In: JANCSÓ, István; KANTOR, Íris (orgs.). Festa: cultura e sociedade na América Portuguesa. Vol. II. São Paulo: Hucitec, Edusp, Fapesp, Imprensa Oficial, 2001. p. 969-975.

HOBSBAWN, Eric; RANGER, Terence (orgs.). A Invenção das Tradições. Rio de Janeiro: Paz e Terra, 1997. 316 p.

HOGGART, Richard. As utilizações da cultura. Aspectos da vida cultural da classe trabalhadora, com especiais referências a publicações e divertimentos. Tradução de Maria do Carmo Cary. Lisboa: Editorial Presença, LDA, 1973.

HOLANDA, Sérgio Buarque de. Raízes do Brasil. 26ª ed. São Paulo: Cia. das Letras, 1995. $220 \mathrm{p}$.

JANCSÓ, István; KANTOR, Íris (orgs.). Falando de festas. In: Festa: cultura e sociedade na América Portuguesa. Vol. I. São Paulo: Hucitec, Edusp, Fapesp, Imprensa Oficial, 2001. p. 3-13.

KATO, Alice; MORLINI, Alfredo. Divino Espírito Santo. Mogi das Cruzes: Centro Mogiano de Pesquisa, 1973. 21 p.

KOSMINSKY, Ethel Volfzon (org.). A utilização do dado qualitativo e a subjetividade do pesquisador. In: Agruras e prazeres de uma pesquisadora: ensaios sobre a sociologia de Maria Isaura Pereira de Queiroz. Marília: Unesp, Marília Publicações. São Paulo: Fapesp, 1999. p. 77-88.

KOWARICK, Lúcio. Escravos, párias e proletários. Uma contribuição para o estudo da formação do capitalismo no Brasil. 1981. Tese (Livre-Docência em Ciências Sociais) Departamento de Ciências Sociais, Universidade de São Paulo, São Paulo, 1981.

LA BLACHE, P. Vidal de. Les Genres de Vie dans La Géographie Humaine. (Artigos I e II). Tradução de Regina Sader (mimeo). In: Annales de Géographie no 111 - XX Année 15/05/1911, e no 112 - 15/06/1911.

LARAIA, Roque de Barros. Cultura. Um conceito antropológico. 13 ${ }^{\mathrm{a}}$ ed. Jorge Zahar Editor. Rio de Janeiro, 2000. 116 p.

LEFEBVRE, Henri. A práxis. In: Sociologia de Marx. Tradução de Carlos Roberto Alves Dias. $2^{\mathrm{a}}$ ed. brasileira. Rio de Janeiro: Forense-Universitária, 1979. p. $22-44$.

La production de l'espace. Paris: Anthropos, 1974. 485 p.

UFMG, 1999. $178 \mathrm{p}$.

A revolução urbana. Tradução de Sérgio Martins. Belo Horizonte: Ed.

. De lo rural a lo urbano. Barcelona: Ediciones Península, 1978. 268 p.

Espacio y política. El derecho a la ciudad, II. Barcelona: Ediciones

Península. $1976.157 n$ 
La presencia y la ausência. Contribuición a la teoria de las representaciones. México: Fondo de Cultura Econômica, 1983. 276 p.

Le Retour de la Dialectique: 12 mots clef pour le monde moderne. Paris, Messidor/Éditions Sociales, 1986.

LEFEBVRE, Henri. Le romantisme Revolutionnaire. In: Au-delà du structuralisme. Paris: Éditions Anthropos, 1971. p. 27-50.

Lógica formal, lógica dialética. $6^{\mathrm{a}}$ ed. Rio de Janeiro: Civilização Brasileira, 1995. $301 \mathrm{p}$.

Metafilosofia: Prolegômenos. Tradução e Introdução de Roland Corbisier. Rio de Janeiro: Civilização Brasileira, 1967. 399 p.

Notes écrites um dimarche dans la campagne française. In: Critique de la Vie Quotidienne I. Introduction. 2a ed. Paris: L'Arche Editeur, 1958. p. 215-241.

Moraes Ltda., 1991. 145 p.

O direito à cidade. Tradução de Rubens Eduardo Frias. São Paulo: Ed.

LÖWY, Michel. Marxismo e Romantismo em Mariátegui. Teoria \& Debate. Revista Trimestral da Fundação Perseu Abramo. Abo 12, n. 41. p. 38-45, mai/jun/jul. 1999.

Le marxisme romantique. M (mensuel, marxisme, mouvement). N. 50, p. 6-8. Paris: Syllepse, décembre de 1991.

MACEDO, Valéria Mendonça de. O império das festas. O império do Divino e outras festividades católicas no Rio de Janeiro oitocentista. 2002. 191 p. Dissertação (Mestrado em Antropologia Social) - Departamento de Antropologia, Universidade de São Paulo, São Paulo, 2002.

MACHADO, Lia Osório. As idéias no lugar. O desenvolvimento do pensamento geográfico no Brasil no início do século XX. Terra Brasilis - Revista da História do Pensamento Geográfico no Brasil. Rio de Janeiro, ano 1, $\mathrm{n}^{\mathrm{o}}$ 2., 2000. p. 11-31.

MAGALHÃES, Beatriz Ricardina. O Divino e a "Festa do Martírio". In: JANCSÓ, István; KANTOR, Íris (orgs.). Festa: cultura e sociedade na América Portuguesa. Vol. II. São Paulo: Hucitec, Edusp, Fapesp, Imprensa Oficial, 2001. p. 935-947.

MAIA, Doralice Sátyro. Tempos lentos na cidade: permanência e transformações dos costumes rurais na cidade de João Pessoa-PB. 2000. 364 p. Tese (Doutoramento em Geografia Humana) - Departamento de Geografia, Universidade de São Paulo, São Paulo, 2000 .

MARIANO, Neusa de Fátima. Fogão de lenha, chapéu de palha. Jauenses herdeiros da rusticidade no processo de modernização. 2000. 273 p. Dissertação (Mestrado em Geografia Humana) - Departamento de Geografia, Universidade de São Paulo, São Paulo, 2001. 
MARTINS, José de Souza (org.). Henri Lefebvre e o retorno à dialética. São Paulo: Hucitec, 1996. 149 p.

- A sociabilidade do homem simples: cotidiano e história na modernidade anômala. São Paulo: Hucitec, 2000. 210 p.

A sociedade vista do abismo: novos estudos sobre exclusão, pobreza e classes sociais. Petrópolis: Vozes, 2002. 228 p.

Capitalismo e tradicionalismo: estudos sobre as contradições da sociedade agrária no Brasil. São Paulo: Pioneira, 1975. 161 p.

O cativeiro da terra. $6^{a}$ edição. São Paulo: Livraria e Editora de Ciências Humanas, 1996. 157 p.

O enigma de Paim Vieira. O Estado de S. Paulo. Caderno Metrópole 2. p. C-11. São Paulo, 21 de abril de 2007.

. Periferia Revisitada. Espaço \& Debates - Revista de Estudos Rurais e Urbanos. São Paulo, ano XVII, nº 42, p. 75-84. NERU, 2001.

MORAES Filho, Mello. Festas e tradições populares no Brasil. São Paulo: Edusp; Belo Horizonte: Ed. Itatiaia, 1979. 312 p.

MORAES, Fernando Oliveira de. A Festa do Divino em Mogi das Cruzes. 2000. 128 p. Dissertação (Mestrado em Comunicação e Artes) - Departamento de Comunicações e Artes, Universidade de São Paulo, São Paulo, 2000.

MORAES, José Geraldo Vinci de. As sonoridades paulistanas: a música popular na cidade de São Paulo - final do século XIX ao início do século XX. Rio de Janeiro: Funarte, 1995. $208 \mathrm{p}$.

NASSER, Ana Cristina Arantes. Sair para o mundo: trabalho, família e lazer na vida dos excluídos. São Paulo: Hucitec, Fapesp, 2001. 285 p.

ORTIZ, Renato. A moderna tradição brasileira. São Paulo: Brasiliense, 1999. 222 p.

PEREIRA, João Baptista Borges; QUEIROZ, Renato da Silva. Por onde anda o Jeca Tatu? Revista USP. São Paulo: USP - Coordenadoria de Comunicação Social, n. 64, p. 7-13, dez./jan./fev. 2004-2005.

PETRONE, Pasquale. Aldeamentos paulistas. São Paulo: Edusp, 1995. 396 p.

PIAZZA, Walter F. Aspectos folclóricos catarinenses. Florianópolis: Edição da Comissão Catarinense do Folclore, 1953. 138 p.

PLANO Diretor do Município de Mogi das Cruzes 1999/2005. Mogi das Cruzes: Prefeitura Municipal. 103 p.

PRADO Jr. A cidade de São Paulo: Geografia e História. São Paulo: Brasiliense, 1998. 93p. 
QUEIROZ, Maria Isaura Pereira de. Carnaval brasileiro. O vivido e o mito. São Paulo: Editora Brasiliense, 1992. 237 p.

Dialética do rural e do urbano: exemplos brasileiros. In: BLAY, Eva. A luta pelo espaço: textos de sociologia urbana. Petrópolis: Vozes, 1978. p. 21-73.

. Relatos Orais: do "indizível” ao "dizível”. p. 14-43. In: SIMON, Olga

de Moraes Von (org.). Experimentos com histórias de vida: Itália-Brasil. São Paulo: Vértice, Editora Revista dos Tribunais, 1988. (Enciclopédia aberta de ciências sociais; v. 5).

Variações sobre a técnica de gravador e registro da informação viva. São Paulo: CERU e FFLCH/USP, 1991 (Coleção de textos, 4). 182 p.

RAMOS, Aluisio W. Fragmentação do espaço da/na cidade de São Paulo. Espacialidades diversas do Bairro da Água Branca. 2001. 196 p. Dissertação (Mestrado em Geografia Humana) - Departamento de Geografia, Universidade de São Paulo, São Paulo, 2001.

RATZEL, F. Antropogeografia. In: MORAES, Antonio Carlos R. Moraes. (Org.) Ratzel. Ed. Ática, São Paulo, 1990. 199 p.

RE CONHECER a Festa do Divino. Mogi das Cruzes: UBC, Secretaria Municipal de Educação e Cultura, Governo do Município de Mogi das Cruzes, 1994. 12 p.

RIBEIRO, Darcy. O povo brasileiro: a formação e o sentido do Brasil. $2^{\mathrm{a}}$ ed. São Paulo: Cia. das Letras, 1995. 476 p.

RODRIGUES, Herbert. Entre o espetáculo e a devoção. A Festa do Divino Espírito Santo em Mogi das Cruzes (SP). 2006. 163 p. Dissertação (Mestrado em Antropologia Social) Departamento de Antropologia, Universidade de São Paulo, São Paulo, 2006.

ROGRIGUES Filho, José Maria; De CARLO Filho, José. Das origens à Festa do Divino. Mogi das Cruzes S. P. $2^{\mathrm{a}}$ ed. São Paulo, 2004. 104 p.

SANTANA, Antonio Carlos da Paz. A organização e inserção da produção de pequenas unidades agrícolas nos mercados paulistanos: os agricultores do bairro rural de Santo Ângelo. 2006. 179 p. Dissertação (Mestrado em Geografia Humana) - Departamento de Geografia, Universidade de São Paulo, São Paulo, 2006.

SANTOS, José Luiz dos. O que é cultura. $8^{\mathrm{a}}$ ed. São Paulo: Ed. Brasiliense, 1989. 89 p.

SANTOS, Rosselvelt José. Festa no cerrado. Travessia - Revista do Migrante. São Paulo, Centro de Estudos Migratórios, ano XI, nº 31, p. 17-21, mai-ago. 1998.

SATRIANI, Luigi M. Lombardi. Antropologia cultural e análise da cultura subalterna. São Paulo: Hucitec, 1986. 162 p.

SCHWARCZ, Lilia Moritz; MACEDO, Valéria Mendonça de. O império das festas e as festas do Império. In: SCHWARCZ, Lilia Moritz. As barbas do imperador: D. pedro II, um momarca nos trópicos. São Paulo: Companhia das Letras, 1998. p. 247-294.

SEABRA. Odette Carvalho de Lima. Urbanizacão e fragmentacão. Cotidiano e vida de pdfMachine

A pdf writer that produces quality PDF files with ease!

Produce quality PDF files in seconds and preserve the integrity of your original documents. Compatible across nearly all Windows platforms, simply open the document you want to convert, click "print", select the "Broadgun pdfMachine printer" and that's it! Get yours now! 
bairro na metamorfose da cidade em metrópole, a partir das transformações do Bairro do Limão. 2003. 397 p. Tese (Livre-Docência, Geografia Humana) - Departamento de Geografia; Universidade de São Paulo, São Paulo, 2003.

Urbanização. Bairro e vida de bairro. Travessia - Revista do Migrante. São Paulo, Centro de Estudos Migratórios, ano XIII, nº 38, p. 11-17, set-dez. 2000.

SILVA, Maria Aparecida Moraes. Como "expulsar o camponês" do proletariado. Travessia - Revista do Migrante. São Paulo, Centro de Estudos Migratórios, ano III, no 8, p. 5-11, setdez. 1990.

SILVA, Sidney Antonio da. Tradições religiosas e cultura no Brasil. Travessia - Revista do Migrante. São Paulo, Centro de Estudos Migratórios, ano XVI, nº 46, p. 27-30, mai-agos. 2003.

Virgem/Mãe/Terra: festas e tradições bolivianas na metrópole. São Paulo: Hucitec, Fapesp, 2003. 263 p.

SINGER, Paul Israel. Desenvolvimento econômico e evolução urbana: análise da evolução econômica de São Paulo, Blumenau, Porto Alegre, Belo Horizonte e Recife. $2^{\mathrm{a}}$ ed. São Paulo: Ed. Nacional, 1977. 377 p.

SORRE, Maximillien. Max Sorre: Geografia. São Paulo: Ática, 1984. 192 p.

SOUZA, Laura de Mello e. O diabo e a terra de Santa Cruz: feitiçaria e religiosidade popular no Brasil colonial. São Paulo: Companhia das Letras, 1986a. 396 p.

O falso fausto. In: - Desclassificados do ouro: a pobreza mineira no século XVIII. 2a ed. Rio de Janeiro: Edições Graal, 1986b. p. 19-43.

SOUZA, Marina de Mello e. Reis negros no Brasil escravista: história da festa de coroação de Rei Congo. Belo Horizonte: Editora UFMG, 2002. 387 p.

THOMPSON, E. P. Costumes em comum. Estudos sobre a cultura popular tradicional. São Paulo: Cia. Das Letras, 1998. 493 p.

TINHORÃO, José Ramos. As festas no Brasil colonial. São Paulo: Editora 34, 2000. 173p.

TRADICIONAL Festa do Divino Espírito Santo. Mogi das Cruzes. 12 a 22 de maio de 1994. Mogi das Cruzes, 1994. 30 p.

WAGNER, Philip L.; MIKESELL, Marvin W. Temas da Geografia Cultural. In: CORREA, Roberto Lobato; ROZENDAHL, Zeni (orgs.). Geografia Cultural: um século (1). Rio de Janeiro: EdUERJ, 2000. p. 111-167.

WILLIAMS, Raymond. O campo e a cidade na História e na Literatura. São Paulo: Cia. das Letras, 1989. 439 p.

WOORTMANN, Klaas. "Com parente não se neguceia". O campesinato como ordem social. p. 11-73. In: Anuário Antropológico/87. Brasília: Editora Universidade de Brasília, Tempo Brasileiro, 1990. 


\section{Imagens}

DIVINO Espírito Popular. Produção de Pedro Abib. Mogi das Cruzes, 2004. 1 videocassete.

FESTA do Divino Espírito Santo de Santa Isabel. Produção de Artur Pereira. São Paulo, 1933. Acervo Histórico da Discoteca Oneyda Alvarenga do Centro Cultural São Paulo. 1 DVD.

\section{Iconografia}

MONTEIRO, Firmino de (1855-1888). Bandeira do Divino. 1 original de arte, óleo sobre tela. Acervo da Pinacoteca do Estado de São Paulo.

SOUZA, Emigdio de (1868-1949). Bandeira do Divino. 1 original de arte, óleo sobre tela. Acervo da Pinacoteca do Estado de São Paulo.

ANDERE, Maurício. Bandeiras do Divino. 1 foto colorida (cartão postal). Mogi das Cruzes: Prefeitura Municipal de Mogi das Cruzes - Secretaria Municipal de Educação e Cultura, 1994.

\section{Cartografia}

FESTA do Divino 2005. Mogi das Cruzes. Mogi News, 05 Maio de 2005, p. 3. 1 Croqui pb. Sem Escala.

MARCOS, Antonio do Nascimento. Planta da cidade de Mogy das Cruzes. São Paulo. Mogi das Cruzes, 1901. 1 mapa pb. Escala: 1:2.000.

PREFEITURA Municipal de Mogi das Cruzes. Centro da Cidade. Mogi das Cruzes: Secretaria Municipal de Planejamento e Urbanismo - Divisão de Geoprocessamento, 2006. 1 mapa color. Escala: 1:10.000.

PREFEITURA Municipal de Mogi das Cruzes. Situação/Dados Gerais. Mogi das Cruzes, Secretaria Municipal de Planejamento. S/d. 1 mapa color. Escala 1: 1000000.

\section{Registro Sonoro}

A FESTA do Divino em Mogi das Cruzes. Mogi das Cruzes: Produzido por Pedro do Carmo e Rabicho, 2003. 1 CD (49min., 39seg.). 


\section{Website}

ASSOCIAÇÃO Pró-Festa do Divino Espírito Santo. Mogi das Cruzes. Disponível em: http://www.festadodivino.org.br. Acesso em abr. 2004 -.

DIOCESE de Mogi das Cruzes. Mogi das Cruzes. Disponível em: http://www.diocesedemogi.org.br. Acesso em mar. 2007.

FUNDAÇÃO Sistema Estadual de Análise de Dados. São Paulo. Disponível em: http://www.seade.gov.br. Acesso em abr. 2007.

INSTITUTO Brasileiro de Geografia e Estatística. Rio de Janeiro. Disponível em: http://www.ibge.gov.br. Acesso em abr. 2007.

O PORTAL da Festa do Divino Espírito Santo. Rio de Janeiro. Disponível em: http://www.portaldodivino.hpgplus.com.br. Acesso em abr. 2004.

PREFEITURA Municipal de Guararema. Guararema. Disponível em: http://www.guararema.sp.gov.br. Acesso em mar. 2007.

PREFEITURA Municipal de Mogi das Cruzes. Mogi das Cruzes. Disponível em: http://www.pmmc.com.br. Acesso em abr. 2004 -.

UNIVERSIDADE Braz Cubas. Mogi das Cruzes. Disponível em: http://www.brazcubas.br. Acesso em fev. 2007.

UNIVERSIDADE de Mogi das Cruzes. Mogi das Cruzes. Disponível em: http://www.umc.br. Acesso em fev. 2007.

\section{Jornais}

O DIÁRIO DE MOGI. Mogi das Cruzes: 1960-. Diário. Maio-jun. de 1960-2006.

MOGI NEWS. Mogi das Cruzes. Diário. 05 mai. 2005.

O LIBERAL. Mogi das Cruzes. Diário. Maio de 1931-1932.

O YPIRANGA. Mogi das Cruzes. 02 jul. 1899.

\section{Fontes Primárias}

\section{Arquivo da Cúria Metropolitana de São Paulo - ACMSP}

Pastas Avulsas (I a XIII) Mogi das Cruzes, SP. 
Termos de Entrada de Irmãos 1722-1836. Arquidiocese de São Paulo. Irmandade de Nossa Senhora do Rosário dos Homens Pretos de Mogi das Cruzes.

Registro de provisões: 1818-1827; 1828-1835; 1844-1849; 1851-1857; 1857-1860; 1861$1863 ; 1863-1865 ; 1865-1867 ; 1867-1870 ; 1870-1872 ; 1872-1875 ; 1875-1878 ; 1878-1881$; $1881-1884 ; 1884-1887 ; 1887-1889 ; 1889-1892 ; 1892-1895 ; 1895-1899$.

\section{Arquivo Histórico e Pedagógico de Mogi das Cruzes}

Livro de Ouro da Festa do Divino Espírito Santo, de 1938.

\section{Entrevistados $^{182}$}

1. Airton Nogueira

2. Albertina

3. Carlos

4. Carlos Henrique (Caíque)

5. Chico Preto

6. Ana

7. Terezinha

8. Dina

9. Helena

10. Rita

11. Miled e Maria José

12. Márcia

13. Elisete

14. Eulália

15. Georgina Leite

16. Gislaine
$18 / 08 / 2006$

$16 / 08 / 2006$

$26 / 08 / 2006$

26/08/2006

$12 / 05 / 2005$

$25 / 01 / 2006$

$25 / 01 / 2006$

$27 / 09 / 2006$

$13 / 05 / 2005$

$24 / 04 / 2006$

$27 / 03 / 2006$

$27 / 03 / 2006$

$16 / 08 / 2006$

$27 / 09 / 2006$

$15 / 08 / 2006$

$24 / 04 / 2006$

182 As entrevistas foram transcritas nor uma empresa esnecializada Transcreve pdfMachine A pdf writer that produces quality PDF files with ease!

Produce quality PDF files in seconds and preserve the integrity of your original documents. Compatible across nearly all Windows platforms, simply open the document you want to convert, click "print", select the "Broadgun pdfMachine printer" and that's it! Get yours now! 
17. Jorge Correia

$23 / 08 / 2006$

18. Josemir Ferraz

$26 / 09 / 2006$

19. Jurandyr Ferraz

$22 / 09 / 2006$

20. Maria do Carmo

$23 / 08 / 2006$

21. Mathias Tomasulo

$21 / 09 / 2006$

22. Mário Sérgio

$12 / 08 / 2006$

23. Mônica

$29 / 08 / 2006$

24. Darwin de Oliveira (Nego Otaviano)

$22 / 08 / 2006$

25. Padre Claudionir

$16 / 08 / 2006$

26. José Luís (Rabicho)

$07 / 10 / 2006$

27. Reginaldo

$15 / 08 / 2006$

28. Salete

$15 / 08 / 2006$

29. Saul Grinberg

$07 / 10 / 2006$

30. Sebastiana

$19 / 09 / 2006$

31. Roberto

$21 / 04 / 2006$

32. Geraldo (Dico)

$20 / 10 / 2006$

33. Lúcia

20/10/2006

34. Vicente

$31 / 03 / 2006$

35. Cida

$31 / 03 / 2006$

36. Thaís, Zoraide, Tânia, Eli, Marcos

20/08/2006

37. Ulisses

$19 / 09 / 2006$

38. José Tavares

$27 / 09 / 2006$

\section{pdfMachine}

A pdf writer that produces quality PDF files with ease!

Produce quality PDF files in seconds and preserve the integrity of your original documents. Compatible across nearly all Windows platforms, simply open the document you want to convert, click "print", select the 


\begin{abstract}
ANEXOA
Solicitação de prendas distribuída aos estudantes, nas escolas
\end{abstract}

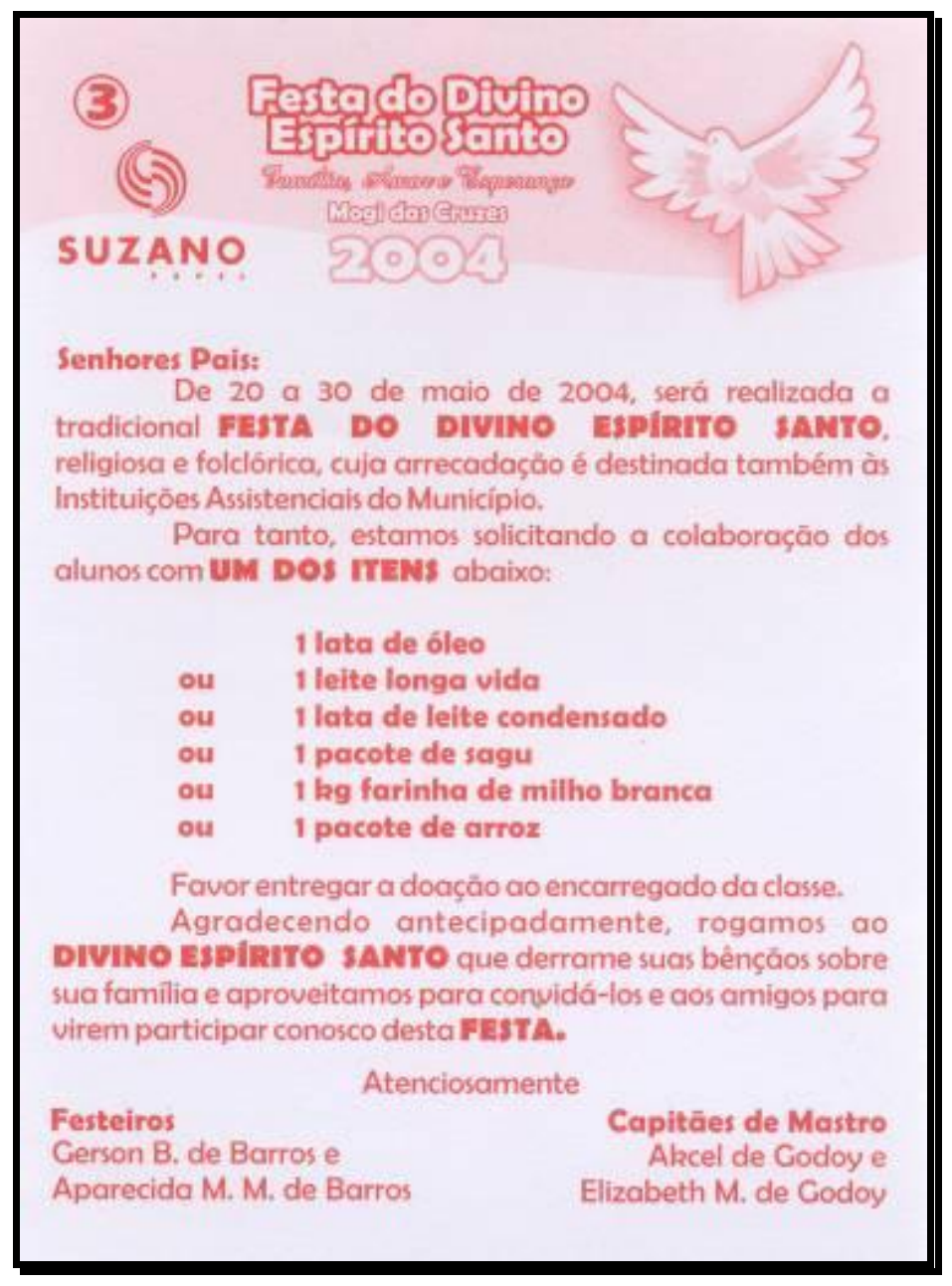

\title{
pdfMachine
}

\section{A pdf writer that produces quality PDF files with ease!}

Produce quality PDF files in seconds and preserve the integrity of your original documents. Compatible across nearly all Windows platforms, simply open the document you want to convert, click "print", select the 


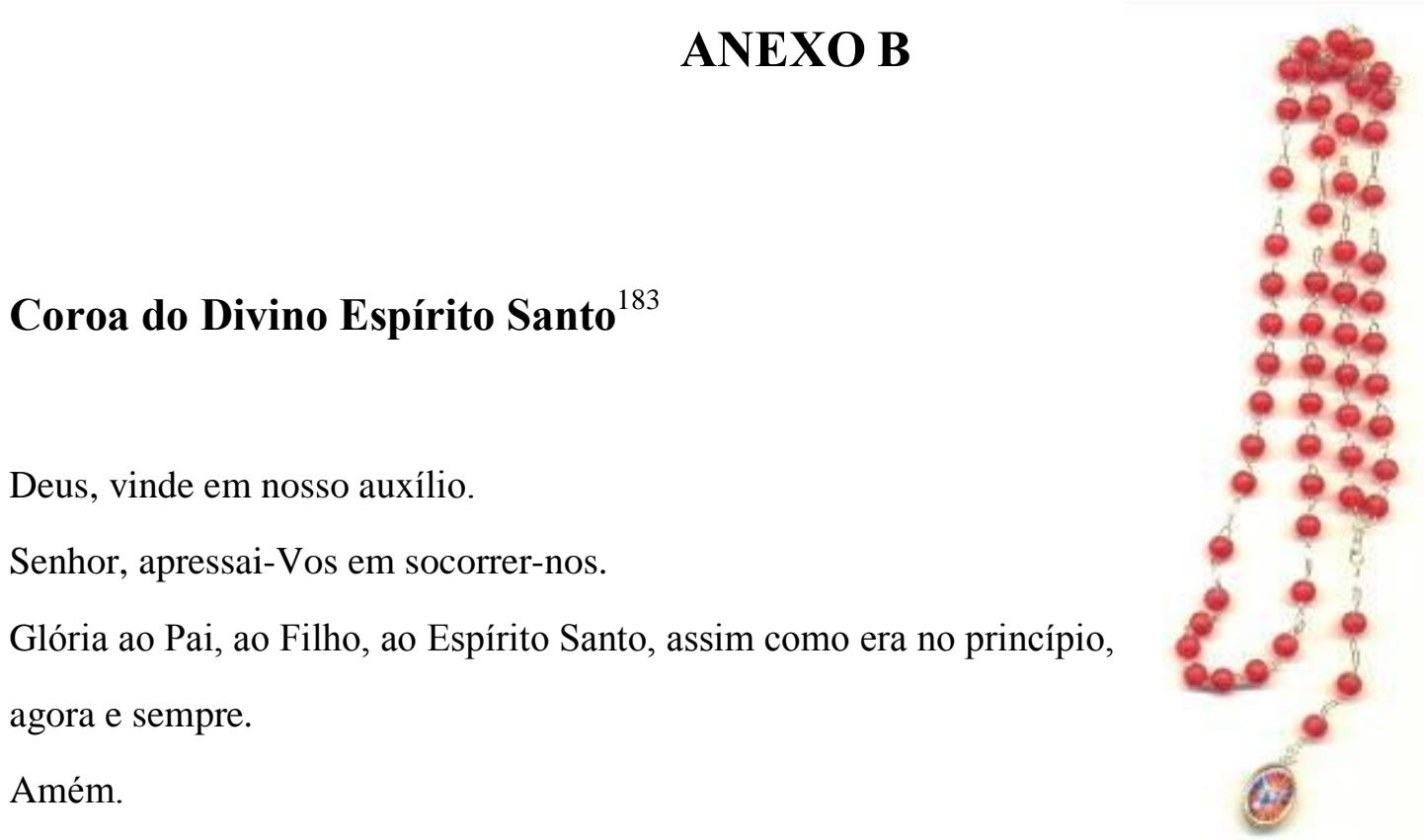

10. Mistério - Vinde Espírito de Sabedoria, desprendei-nos das coisas da Terra e infundinos o amor e o gosto pelas coisas do Céu.

- Vinde Espírito Santo, enchei os corações dos vossos fiéis e acendei neles o Fogo do Vosso amor. Vinde e renovai a face da Terra. (repete-se sete vezes a mesma invocação) - Ó Maria, que por obra do Espírito Santo concebestes o Salvador, rogai por nós.

2o. Mistério - Vinde Espírito de Entendimento, iluminai a nossa mente com a luz da Eterna Verdade e enriquecei-a de puros e santos pensamentos.

- Vinde Espírito Santo, ... (sete vezes)

- Ó Maria, ...

3o. Mistério - Vinde Espírito de Bom Conselho, fazei-nos dóceis às Vossas santas aspirações e guiai-nos no caminho da salvação.

- Vinde Espírito Santo, ... (sete vezes)

- Ó Maria, ... 
4o. Mistério - Vinde Espírito de Fortaleza, dai-nos força, constância e vitória nas batalhas contra os nossos inimigos espirituais e corporais.

- Vinde Espírito Santo, ... (sete vezes)

- Ó Maria, ...

5o. Mistério - Vinde Espírito de Ciência, sede o Mestre de nossas almas e ajudai-nos a praticar os Vossos santos ensinamentos.

- Vinde Espírito Santo, ... (sete vezes)

- Ó Maria, ...

6o. Mistério - Vinde Espírito de Piedade, vinde morar em nossos corações, tomai conta deles e santificai todos os seus afetos.

- Vinde Espírito Santo, ... (sete vezes)

- Ó Maria, ...

7o. Mistério - Vinde Espírito do Santo Temor de Deus, reinai em nossa vontade e fazei que estejamos sempre dispostos a antes sofrer e morrer que Vos ofender.

- Vinde Espírito Santo, ... (sete vezes)

- Ó Maria, ...

\section{Três Invocações a Maria Santíssima}

1a. Ó puríssima Virgem Maria, que pela Vossa Conceição Imaculada fostes pelo Espírito Santo transformada em tabernáculo predileto da Divindade, rogai por nós.

- Para que o Divino Paráclito venha o quanto antes renovar a face da Terra.

-Ave Maria...

183 Fonte $h$ htn $/ /$ wuww fectadodivino oro hr-acesso em marco de 2007 
2a. Ó puríssima Virgem Maria, que no mistério da Encarnação, Vos tornastes pela virtude do Espírito Santo verdadeira Mãe de Deus, rogai por nós.

- Para que ...

-Ave Maria...

3a. Ó puríssima Virgem Maria, que no Cenáculo, em oração com os apóstolos, fostes repleta do Espírito Santo, rogai por nós.

- Para que...

-Ave Maria...

Vinde Espírito Santo, enchei os corações dos Vossos fiéis e acendei neles o Fogo do Vosso Divino Amor.

Enviai o vosso Espírito e tudo será criado, e assim então, renovareis a face da Terra.

Oremos: Ó Deus, que instruístes os corações dos Vossos fiéis com as luzes do Espírito Santo, fazei que apreciemos retamente todas as coisas segundo o mesmo Espírito e gozemos sempre de sua consolção, por Cristo, Nosso Senhor. Amém.

\section{Oração a Nossa Senhora}

Senhor Jesus Cristo, Filho de Deus Pai, peço-Vos enviar agora à Terra o Vosso Espírito.

Fazei que o Espírito Santo habite no coração de todos os povos, a fim de que sejamos preservados da corrupção, das calamidades e da guerra.

Seja a Senhora de todos os povos, Maria Santíssima, a nossa advogada. Amém. 


\title{
ANEXO C
}

\section{Músicas $^{184}$}

\author{
A Bandeira do Divino \\ Ivan Lins e Vitor Martins
}

Os devotos do Divino

vão abrir sua morada

pra bandeira do Menino

ser bem-vinda, ser louvada.

Deus nos salve esse devoto

pela esmola em Vosso nome

dando água a quem tem sede

dando pão a quem tem fome.
Que o perdão seja sagrado

que a fé seja infinita

que o homem seja livre

que a justiça sobreviva.
Assim como os três reis magos

que seguiram a estrela guia

a bandeira segue em frente

atrás de melhores dias.

\begin{abstract}
A bandeira acredita
que a semente seja tanta

que esta mesa seja farta

que esta casa seja santa.
\end{abstract}

No estandarte vai escrito

que Ele voltará de novo

e o Rei será bendito

Ele nascerá do povo.

${ }^{184}$ Fonte: Cânticos da Alvorada da Festa do Divino Espírito Santo de Mogi das Cruzes. 29 de maio a 08 de junho de 2003. 


\section{A Nós Descei Divina Luz}

A nós descei Divina Luz (2x)

Em nossas almas acendei

o amor, amor de Jesus (2x)

Vinde Santo Espírito e do céu mandai

de Tua Luz um raio $(2 \mathrm{x})$

Vinde Pai dos pobres doador dos dons

Luz dos corações $(2 \mathrm{x})$

Grão-Consolador nossa alma habitais

e nos confortais $(2 \mathrm{x})$

$\mathrm{Na}$ fadiga, repouso e no ardor, brandura

e na dor, ternura $(2 \mathrm{x})$

A nós...

Ó Luz venturosa que vossos clarões

encham os corações $(2 \mathrm{x})$

Sem vosso poder nada há no vivente

nada de inocente $(2 \mathrm{x})$

Lavai o impuro e regai o seco

curai o enfermo $(2 \mathrm{x})$

Dobrai a dureza, aquecei o frio

livrai do desvio $(2 \mathrm{x})$

A nós...

Aos vossos fiéis, que confiastes, oram

Dai os sete dons $(2 \mathrm{x})$

Dai virtude e prêmio, e no fim dos dias

Eterna alegria $(2 \mathrm{x})$

A nós...

\section{Vem Espírito Santo}

Vem Espírito Santo, vem!

Vem iluminar!

Nossos caminhos, vem iluminar

Nossas idéias, vem iluminar

Nossas angústias, vem iluminar

Vem...

Toda Igreja, vem iluminar

A nossa vida, vem iluminar

Nossas famílias, vem iluminar

Toda a Terra, vem iluminar

Vem...

Os servidores, vem iluminar

Nossos padres, vem iluminar

Comunidades, vem iluminar

Todo o povo, vem iluminar, vem iluminar

Vem...

Nossos pastores, vem iluminar

O nosso bispo, vem iluminar

Seu rebanho, vem iluminar

Vem... 


\section{ANEXO D}

\section{Programação da Festa do Divino Espírito Santo}

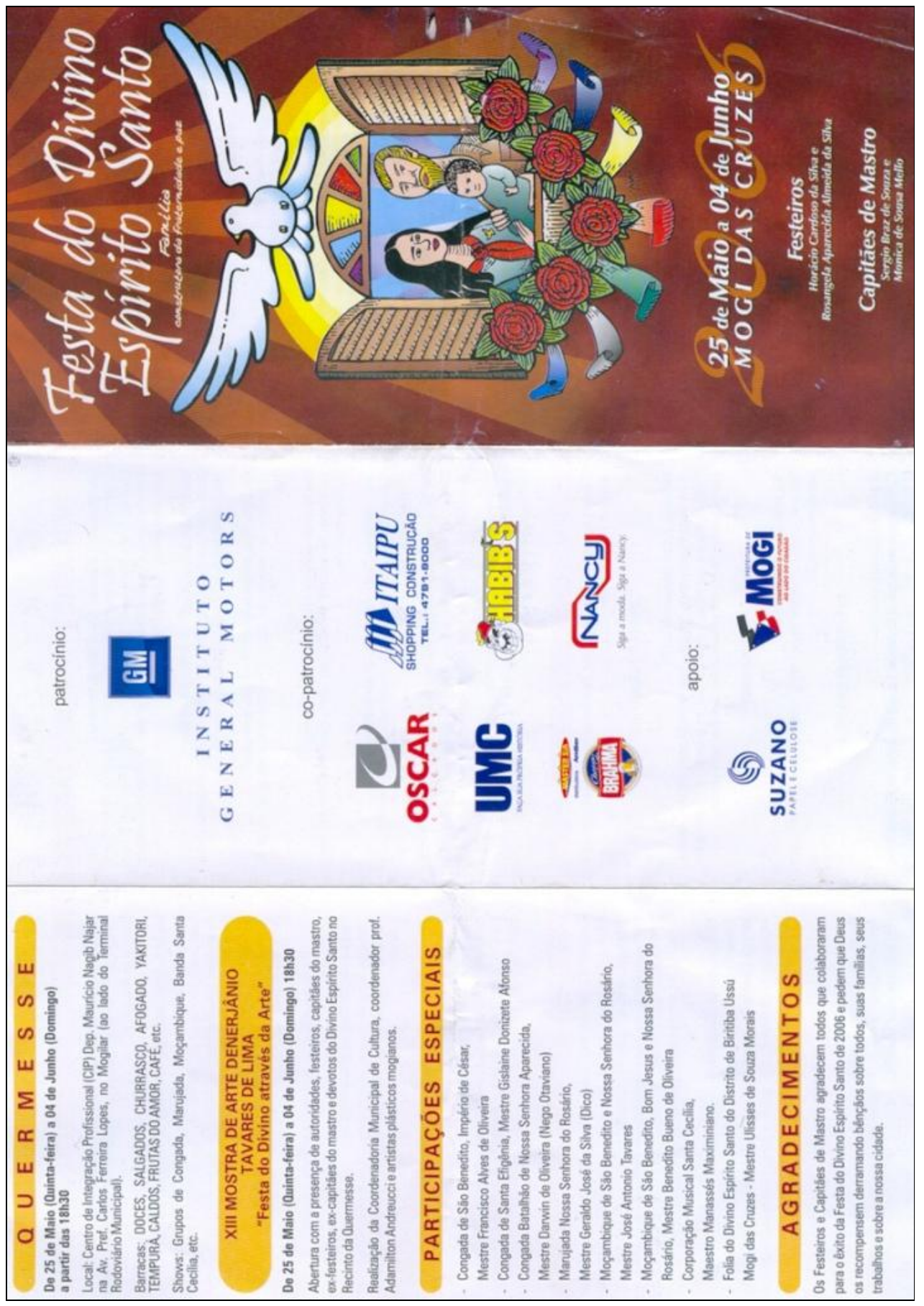

\section{pdfMachine}

A pdf writer that produces quality PDF files with ease!

Produce quality PDF files in seconds and preserve the integrity of your original documents. Compatible across nearly all Windows platforms, simply open the document you want to convert, click "print", select the "Broadgun pdfMachine printer" and that's it! Get yours now! 


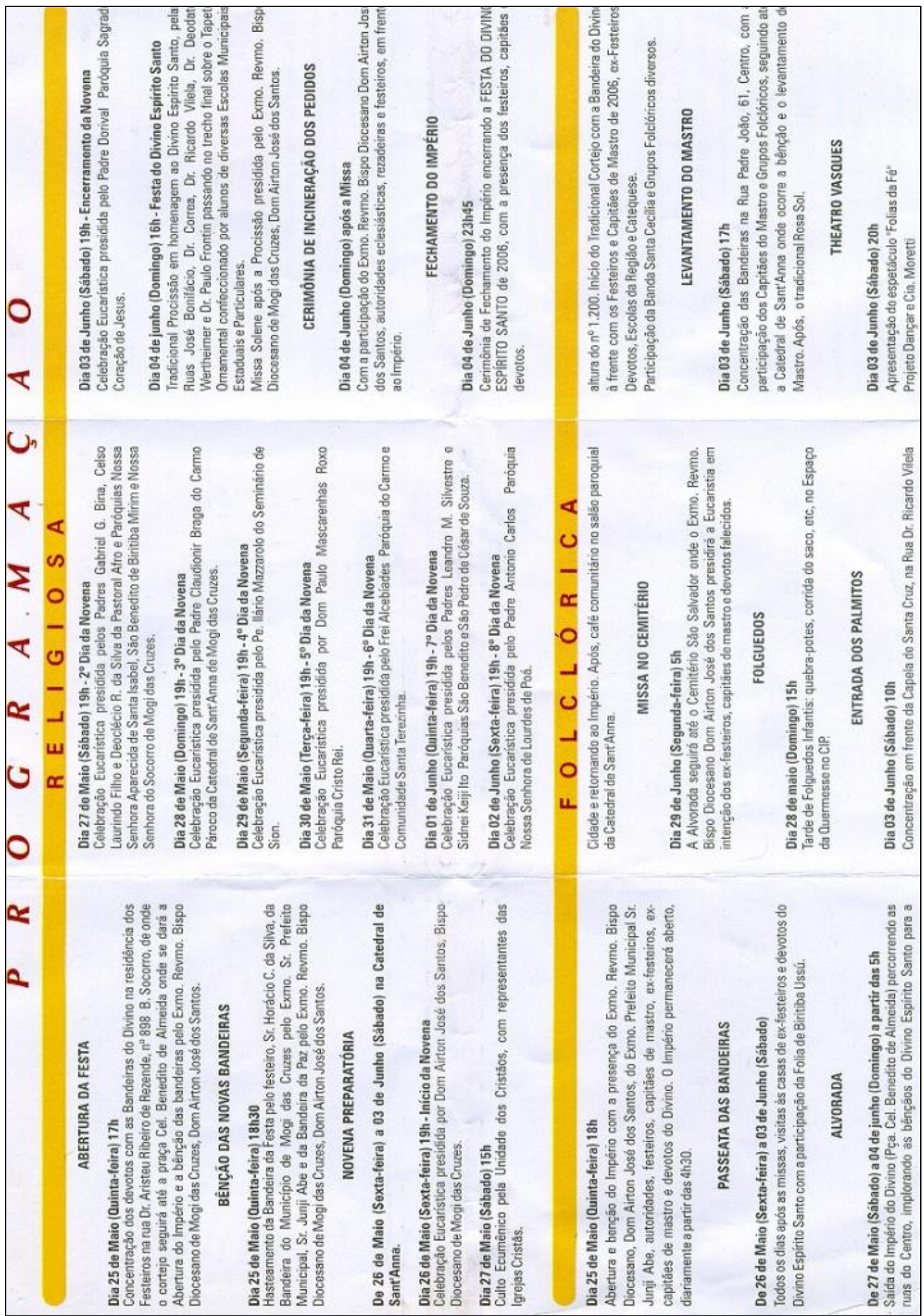

\section{pdfMachine}

A pdf writer that produces quality PDF files with ease!

Produce quality PDF files in seconds and preserve the integrity of your original documents. Compatible across

nearly all Windows platforms, simply open the document you want to convert, click "print", select the 


\section{ANEXO E}

\section{Texto sobre a Festa do Divino distribuído na Entrada dos Palmitos}

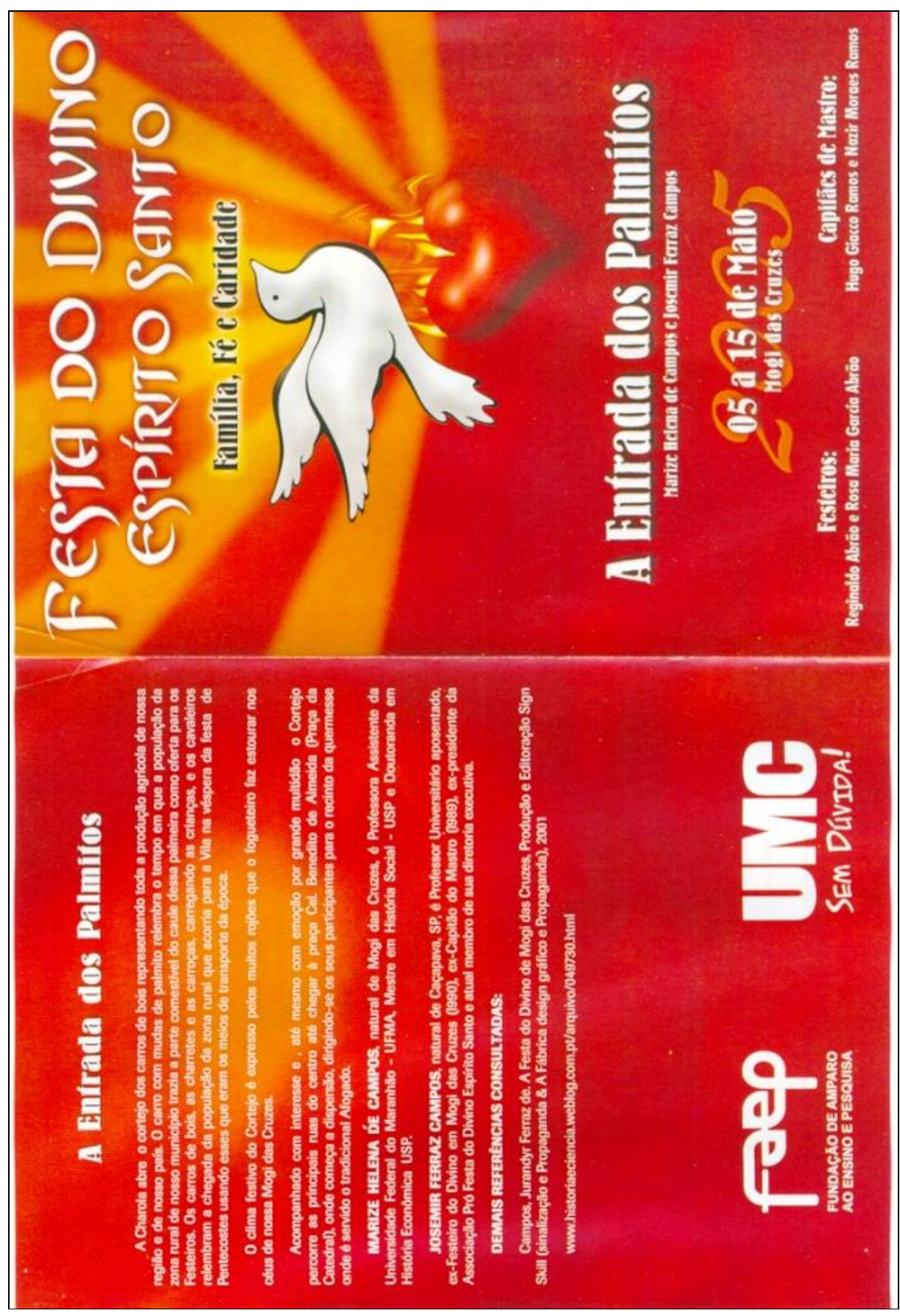

\section{pdfMachine}

A pdf writer that produces quality PDF files with ease!

Produce quality PDF files in seconds and preserve the integrity of your original documents. Compatible across

nearly all Windows platforms, simply open the document you want to convert, click "print", select the

"Broadgun pdfMachine printer" and that's it! Get yours now! 


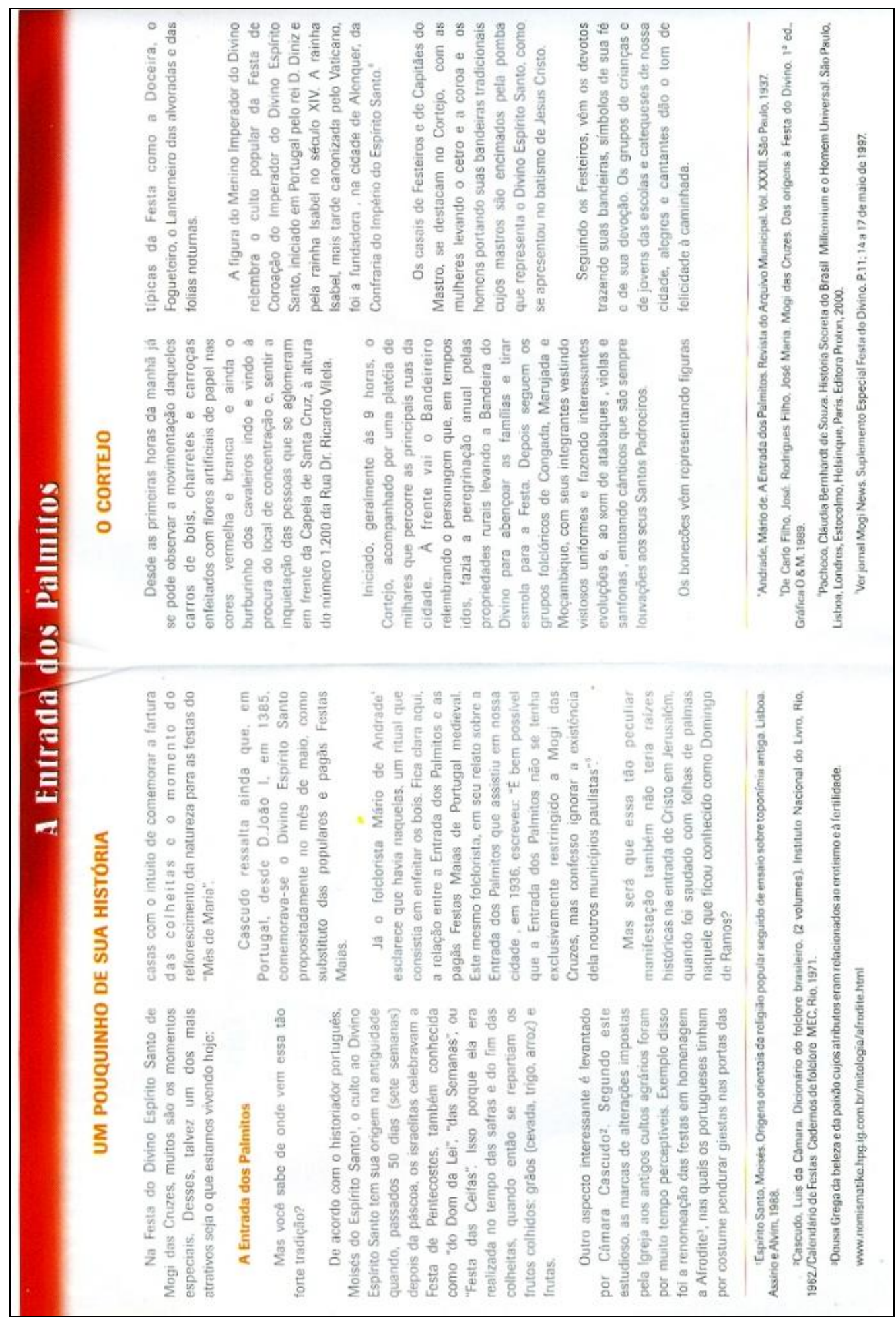

pdfMachine

A pdf writer that produces quality PDF files with ease!

Produce quality PDF files in seconds and preserve the integrity of your original documents. Compatible across

nearly all Windows platforms, simply open the document you want to convert, click "print", select the

"Broadgun pdfMachine printer" and that's it! Get yours now! 


\section{ANEXO F}

\section{Músicas dos Grupos de Congada e Moçambique ${ }^{185}$}

\section{Bendito Louvado seja}

Moçambique de São Benedito e

Nossa Senhora do Rosário

Bendito Louvado seja

Bendito seja louvado

O Divino Espírito Santo

Bom Jesus crucificado.

\section{Vamos com Deus}

Congada de Santa Efigênia

\section{São Benedito, Deus no scéu e nada mais}

\section{Congada de São Benedito}

São Benedito é Deus no céu e nada mais

Ai, ai, ai, ai...

A falsidade nesse mundo é muito grande

Por isso ele na terra não volta mais

Quem somos nós

Pra viver entre o mal e o bem

Deus é maior e mais ninguém

Vamos com Deus

Ô Virgem Maria

Com o Divino Espírito Santo

Santa Efigênia é nossa guia.

${ }^{185}$ Fonte: A FESTA do Divino em Mogi das Cruzes. Mogi das Cruzes: Produzido por Pedro do Carmo e Rabicho, 2003. 1 CD (49min., 39seg.). 